\title{
Ore Deposits of the
}

Antler Peak Quadrangle

Humboldt and Lander

Counties, Nevada

GEOLOGICAL SURVEY PROFESSIONAL PAPER 459-B

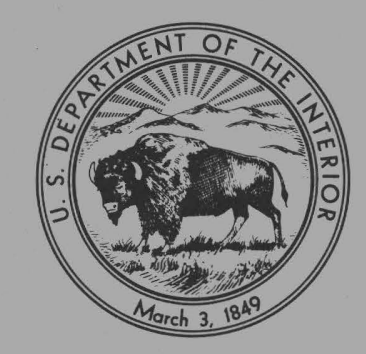


Ore Deposits of the

Antler Peak Quadrangle

Humboldt and Lander

Counties, Nevada

By RALPH J. ROBERTS and D. C. ARNOLD

GEOLOGY OF THE ANTLER PEAK QUADRANGLE, NEVADA

GEOLOGICAL SURVEY PROFESIONAL PAPER 459-B

Summary of base- and precious-metal deposits

in the Battle Mountain mining district

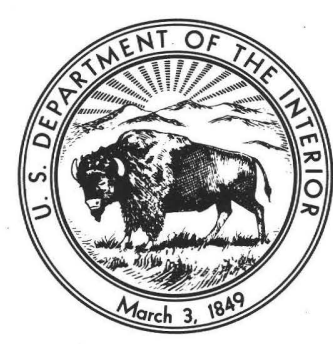

UNITED STATES GOVERNMENT PRINTING OFFICE, WASHINGTON : 1965 


\section{UNITED STATES DEPARTMENT OF THE INTERIOR \\ STEWART L. UDALL, Secretary \\ GEOLOGICAL SURVEY \\ Thomas B. Nolan, Director}

For sale by the Superintendent of Documents, U.S. Government Printing Office Washington, D.C. 20402 


\section{CONTENTS}

Abstract

Introduction

Physical features

Climate.

Water supply

Previous work

Fieldwork and acknowledgments _...

Regional setting

General geology

Sedimentary rocks

Siliceous and volcanic assemblage . . ..........

Cambrian System

Scott Canyon Formation ..........

Ordovician System......................

Valmy Formation

Transitional assemblage. . . . . . . . . .

Cambrian System

Harmony Formation ..............

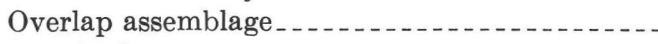

Antler sequence........................

Battle Formation ...................

Antler Peak Limestone

Edna Mountain Formation . .......

Havallah sequence.....................

Pumpernickel Formation . . . . . . . . . . .

Havallah Formation . . . . .

Quaternary System .........................

Igneous rocks . .

Igneous rocks of Paleozoic age

Intrusive rocks of Tertiary age ...........

Granodiorite and quartz monzonite . .....

Igneous metamorphism _...................

Metamorphism of the igneous rocks _.....

Metamorphic zones ...................

Metamorphism of the sedimentary rocks..-

Battle Formation

Pumpernickel Formation . . . . . . . . . .

Havallah Formation

Scott Canyon Formation . . . . . . . .

Harmony Formation

Volcanic rocks of Tertiary and early Quaternary age

Geologic structure

Valmy and Scott Canyon blocks..............

Dewitt block

Antler block

Golconda block

High-angle faults. . .

Ore deposits

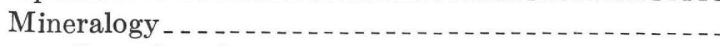

Ore minerals . . . . . . . .

Gold

Silver. - . -

Copper.

Antimony

\begin{tabular}{|c|c|}
\hline age & Ore deposits-Continued \\
\hline B1 & Mineralogy-Continued \\
\hline 2 & Ore minerals-Continued \\
\hline 4 & Lead \\
\hline 4 & Zinc \\
\hline 4 & Cadmium \\
\hline 4 & Iron_-1, \\
\hline 5 & Manganese \\
\hline 6 & Arsenic \\
\hline 6 & Minor minerals \\
\hline 6 & Gangue minerals \\
\hline 6 & Silicates \\
\hline 6 & General character and classification of the ore \\
\hline 6 & deposits \\
\hline 6 & Copper-gold deposits \\
\hline 7 & Replacement deposits \\
\hline 7 & Contact-metamorphic stage \\
\hline 8 & Hydrothermal stage \\
\hline 8 & Supergene mineralization \\
\hline 8 & Supergene copper deposits \\
\hline 8 & Copper-gold veins \\
\hline 8 & Hypogene stage \\
\hline 8 & Supergene stage \\
\hline 8 & Gold-silver deposits \\
\hline 9 & Lead-zinc-silver deposits \\
\hline 9 & Replacement deposits \\
\hline 9 & Contact-metamorphic stage $\ldots \ldots \ldots$ \\
\hline 9 & Hydrothermal stage \\
\hline 9 & Veins \\
\hline 10 & Hypogene mineralization \\
\hline 10 & Supergene mineralization \\
\hline 10 & Antimony deposits \\
\hline 10 & Zonal arrangement of ore deposits \\
\hline 11 & Copper-gold and copper deposits \\
\hline 11 & Gold-silver deposits \\
\hline 11 & Lead-zinc-silver deposits \\
\hline 12 & Antimony deposits. \\
\hline 12 & Age of the mineralization \\
\hline 12 & Geochemical prospecting \\
\hline 13 & Trinity fault \\
\hline 14 & Lucky Strike fault \\
\hline 14 & Plumas fault \\
\hline & Hayden fault \\
\hline 14 & Suggestions for further prospecting \\
\hline 15 & History of mining \\
\hline 16 & Future of the district \\
\hline 16 & Mines_- \\
\hline 16 & Lode deposits \\
\hline 16 & Copper Canyon-Iron Canyon area_....... \\
\hline 17 & Copper Canyon mine (9) \\
\hline 17 & Iron Canyon mine $(17)$ \\
\hline 17 & Nevada mine $(22)$ \\
\hline 17 & Wilson-Independence mine (6) \\
\hline 17 & Tomboy mine (4) \\
\hline 18 & Minnie mine (8) \\
\hline 1 & Independence mine (18) \\
\hline 20 & Western Lock mine $(10) \ldots$ \\
\hline
\end{tabular}

III 
IV

Ore deposits-Continued

Mines-Continued

Lode deposits-Continued

Copper Canyon-Iron Canyon area-Con.

Gold Cash (No Money) mine (7) . . . -

Silver King mine (19)

Monitor claim (12)

Buzzard mine (13)

Other workings in the Buzzard mine area (Nos. 14, 15)

Big Four (Annex) mine (16)

Nevada-Omaha mine (1)

Eldorado mine (11) .

Elko-Lander (21) .................

Dead Horse mine (21a) ............

Meagher mine (23)

Yellow Boy (Oriole) claims (24) .....

Columbia group (25) ...............

Plumas mine (26)

Cleveland claim (27) .............

Galena Canyon area...............

White and Shiloh mine (38) ........

Blossom mine (35) .........

Buena Vista mine (34) ...........

Hard Times claim (37) ...........

Bon Ami claim (45)

Humboldt claim (39) _...............

Spanish and Celia claims (36) .......

Trinity mine (Atlas, 40, Armor 42) ....

Other workings on the Trinity fault...

Eagle mine (48) .............

Moonlight mine (47) . . . . . . - .

Driscol (Denver-Nevada) mine (46) ...

Humbug-Lucky Chance mine (33) -...

Apex Antimony mine (41) ........

North Butte workings (31) _.........

Annie Blaine claim (44) ..........

Bryan mine (32)

Ace of Diamonds claim (43) ........

Butte (Gold Butte) mine (28) .......

Post mine (28a) . . . .

Sioux group (29)

Copper Basin area

History and production.........

Geology - .

Ore deposits

Sweet Marie mine (72) ........

Copper King mine (76) .........

Surprise mine (77)

Carissa mine (73)

Contention mine (66)

Widow mine (71)

Chase mine (69)

Elvira adit (75)

Henrietta $(79,78)$

Pedro (Goff) mine (68)
CONTENTS

Page | Ore deposits-Continued Page Mines-Continued

Lode deposits-Continued

Copper Basin area-Continued

Ore deposits-Continued

Blue Gem Turquoise mine (67) _.. $\quad$ B70

Empire mine (81)

Northern Light (80)

Copperopolis adit (65)

Crown Point Extension claim (74)

Copper Prize (Copper Pick) mine (82)

Peggy group (62a)

Bentley mine (59) .............

O'Leary (Buckingham) mine (57).

Gold Top mine (60) ...........

Copper Queen mine (61 and 62) --

Hawkeye mine (64) ............

Little Giant mine (56)

Irish Rose mine (55)

Lead-Silver deposits northeast of Cop-

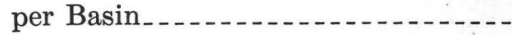

Bailey-Day mine (83)

Elder Creek area.....................

Morning Star mine (89)

Big Pay mine (87)

Gracie (Elder Creek) mine (88) .......

Ridge mine (86)

Scattered mines_....................

Dewitt (Blue Bird) mine (53) ........

Lucky Strike mine (51) ..............

Antimony occurrence on North Peak--

Lauritzen mine (52) ...............

Antimony King mine (49) ...........

Fuller group (50)

Copper Glance group (84) . . . . . . . . - -

Golden Era (Good Chance) group (85).

Marigold mine (90)

Red Rock group (91)

Trenton Copper prospect (92)

Trenton mine (93)

Buffalo Valley mine (94) _...........

Black Rock mine (95) _............

Telluride mine (96) _..............

Modoc mine (97) -

Placer deposits.

Copper Canyon (20) ..................

Natomas (Greenan, Dahl) (5) _........

Box Canyon (3) .......

Philadelphia Canyon (Bannock) (2)

Iron Canyon (17a) ...................

Duck Creek (Galena Canyon) (30).......-

Copper Basin ..........

Vail Canyon (63)

Snow Gulch and Piute Canyon.........

B \& M placer (85a) ..................

Source of the gold.......

References cited

Index 


\section{ILLUSTRATIONS}

[Plates are in separate volume]

Plate 1. Geologic map of the Antler Peak quadrangle.

2. Structure map of the Antler Peak quadrangle.

3. Geologic map and sections of the southeastern part of the Antler Peak quadrangle.

4. Sketch maps showing anomalous distribution of lead and zinc along faults in the Antler Peak quadrangle, Nevada.

5. Claim map of the Copper Canyon-Iron CanyonGalena Canyon area.

6. Composite map of levels, Copper Canyon mine.

7. Geologic map and sections of the Copper Canyon mine area.

8. Geologic maps of the upper underground workings of the Copper Canyon mine.

9. Geologic maps of the lower underground workings of the Copper Canyon mine.

10. Sections through the Copper Canyon mine.

11. Geologic maps, claim map, and sections of the Iron Canyon mine.

12. Geologic maps of mines in the Copper Canyon-Iron Canyon area.

13. Geologic maps of mines in the Galena Canyon area.

14. Claim map of the Copper Basin area.

15. Geologic maps of mines in the Copper Basin area.

16. Geologic maps of mines in the Copper Basin area.

17. Geologic maps of the Bailey Day and mines in the Elder Creek area.

18. Geologic maps of scattered mines.

19. Copper Canyon fan. A, Map of Natomas placer workings. $B$, Isometric diagram showing distribution of gold-bearing gravels.

Figure 1. Index map of north-central Nevada.......-

2. Photomicrograph of metamorphosed sandstone, Harmony Formation

3. A, Plate of native copper, Copper Queen No. 4 mine. $B$, Polished specimen of lead carbonate ore, Lemaire mine, Copper Basin .............................

4. Specimen of sulfide-quartz vein, Hardy vein, O'Leary mine . ....................

5. A, Polished specimen of brecciated sulfide ore, Irish Rose mine. $B$, Photomicrograph of complex sulfide ore, Copper Canyon mine

Page
FIgURE 6. Stalagmites of melanterite, main level, Plumas mine_.......................

7. Sequence of minerals in the copper-gold veins, Copper Canyon area

Page

B22

8. Photomicrographs of quartz-orthoclase vein cutting quartzite of the Battle Formation --

9. Specimen of breccia ore, 700-level stopes, Copper Canyon mine................

10. A, Polished specimen of breccia ore, Copper Canyon mine. $B$, Polished specimen of massive sulfide ore, Iron Canyon mine.---

11. Photomicrographs of replacement minerals formed during hydrothermal stage. $A$, Complex sulfide ore, Copper Canyon mine. $B$, Gold ore, Copper Canyon mine. $C$, Chlorite rosettes between quartz vein and garnet-diopside hornfels of the Battle Formation. D, Pyritic ore, 500 level, Copper Canyon mine

12. A, Polished specimen of chalcocite-pyritecarbonate ore in hornfels of the Battle Formation, Copper Canyon mine. $B$, Chrysocolla-azurite-malachite vein with clay minerals on the Uncle Tom claim --- -

13. A, Veinlets of clay minerals and turquoise cutting hornfels of the Harmony Formation, Blue Gem Turquoise mine. $B$, Photomicrograph of high-grade silver ore, Little Giant mine...................

14. Photomicrograph of turquoise, Blue Gem Turquoise mine, in veinlet cutting clay minerals and in spherulites

15. Map showing zoning of mineral deposits, Battle Mountain district................

16. Copper Canyon glory hole

17. Crescentic longitudinal projection showing stopes in the Copper Canyon mine

18. Longitudinal section in plane of the Virgin vein, Copper Canyon mine.

19. Pebble dike, Contention mine

\section{TABLES}

TABLE 1. Typical analyses of water from wells and springs in the Battle Mountain area

2. Summary of the sedimentary rocks of Paleozoic age, Antler Peak quadrangle

3. Analyses of unmetamorphosed and metamorphosed rocks of the Battle Formation, Antler Peak quadrangle

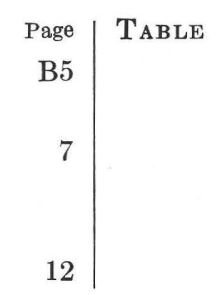

4. Analysis of biotite hornfels of the Harmony Formation, Copper Canyon mine.....-

5. Production of gold, silver, copper, lead, and zinc, Battle Mountain district, 1902-55_--

6. Production of gold, silver, copper, lead, and zinc, Copper Canyon mine, 1871-1954_-.--

7. Production of gold, silver, copper, and turquoise, Copper Basin, 1916-53..........-
Page 



\title{
GEOLOGY OF THE ANTLER PEAK QUADRANGLE, NEVADA
}

\section{ORE DEPOSITS OF THE ANTLER PEAK QUADRANGLE, HUMBOLDT AND LANDER COUNTIES, NEVADA}

\author{
By Ralph J. Roberts and D. C. Arnold
}

\begin{abstract}
The Antler Peak quadrangle, in Humboldt and Lander Counties, north-central Nevada, includes Battle Mountain and parts of the Buffalo Valley and Reese River and Humboldt River valleys. Battle Mountain is a range 18 miles long and 12 miles wide and has a maximum relief of 4,200 feet. The highest point is North Peak, which rises to 8,550 feet, and the second highest is Antler Peak, which rises to 8,236 feet.

Battle Mountain is underlain mainly by sedimentary and volcanic rocks that range in age from Cambrian to Tertiary. Intrusive rocks of early Tertiary age cut the pre-Tertiary rocks and form small stocks, sills, and dikes. Quaternary detrital rocks mantle the flanks of the range and partly fill some of the valleys.

The sedimentary and volcanic rocks of Paleozoic age in northcentral Nevada may be divided into four distinct assemblages: a carbonate assemblage composed mainly of limestone and dolomite; a siliceous and volcanic assemblage containing minor amounts of carbonate; a transitional assemblage composed of interbedded limestone, clastic, and volcanic rocks ; and an overlap of coarse clastic rocks. The first three of these assemblages were deposited in distinct belts in a broad geosyncline-the Cordilleran geosyncline, which extended through Nevada. Following Late Devonian time, these rocks were folded and cut by thrust faults of great magnitude, and the thrust plates were brought together in a most complex manner during the Antler orogeny. Subsequently they were overlapped by clastic rocks of Mississippian to Permian age, which rest unconformably upon the folded and faulted older rocks and are therefore called the overlap assemblage. No rocks of the carbonate assemblage are exposed in Battle Mountain, but they have been found in the Shoshone Range, 10 miles southeast of the Antler Peak quadrangle. All the other assemblages are present in Battle Mountain. The siliceous and volcanic assemblage is represented by the Scott Canyon Formation of late Early or early Middle Cambrian age and the Valmy Formation of Early and Middle Ordovician age; the transitional assemblage, by the Harmony Formation of Late Cambrian age; and the overlap assemblage, by the Battle Formation of early Middle Pennsylvanian age, the Antler Peak Limestone of Late Pennsylvanian and Early Permian age, and the Edna Mountain Formation of Late Permian age. Two Paleozoic units, the Pumpernickel and Havallah Formations, do not belong to any of the four assemblages; they were deposited in western Nevada in a separate basin during the Antler orogeny and following the orogeny.

Deposits of Quaternary and Recent alluvium in the Antler Peak quadrangle include older gravels, older and younger alluvium in the valleys and in the fans that flank the range, and

shoreline deposits and flood-plain deposits of the Reese River and Humboldt River valleys. Gold placer deposits were formed in the older alluvium, particularly in the lower parts of some fans and in some stream channels.

The oldest intrusive rocks in Battle Mountain are plugs, sills, and dikes related to mafic volcanism during Cambrian and Ordovician time. Apparently little intrusive activity took place during the late Paleozoic and Mesozoic; but, during the early Tertiary, quartz monzonite and granodiorite stocks, dikes, and sills were injected. Related dikes include gabbro, diorite, and quartz diorite. Aureoles of contact metamorphism around the larger intrusive bodies are as much as 2 miles wide, but are generally narrower. The effects of the metamorphism include recrystallization of limestone to marble, shale to hornfels, sandstone to quartzite, and chert to a rock resembling quartizite. In addition lime silicate minerals were formed in the calcareous rocks. Pyritization, chloritization, silicification, and argillic alteration of wallrocks was widespread.

Mafic volcanism in the eugeosynclinal basin began in Cambrian time contemporaneously with the deposition of the Scott Canyon Formation and continued at least through the Middle Ordovician ; greenstones in the Pumpernickel Formation indicate volcanism also during Pennsylvanian(?). A younger period of volcanism in Battle Mountain began in the Tertiary, possibly in the Oligocene, and continued intermittently until late Pliocene and early Quaternary. The earliest volcanics are quartz latite welded crystal tuffs and pyroclastics which were followed by olivine basalt flows.

The present topography of Battle Mountain is the result of erosion during late Tertiary and the Quaternary. The oldest feature is an upland surface of low relief, between 7,000 and 8,000 feet altitude, that was formed in late Tertiary. Since then it has been largely dissected so that rugged canyons and steep ridges predominate on the periphery of the range. The range is flanked locally by narrow pediments which pass laterally into fans that extend down into the valleys. The drainage pattern of Battle Mountain is mainly radial, modified locally by a subsequent arrangement of tributaries that have worked headward along fault zones or bedding.

The structural features of Battle Mountain record evidence of recurring orogeny that began in the Paleozoic and continued intermittently until the Quaternary. In all, four major orogenic periods have been distinguished: two took place in the Paleozoic, the first in Late Devonian to Early Pennsylvanian time, the second in the Permian; the third was in the Mesozoic, probably in Jurassic and Cretaceous time; the fourth period began in the Tertiary and extended into the Quaternary. The first three periods are characterized by folding and thrust faulting
\end{abstract}


and the fourth by block faulting, tilting, and only minor folding. The structural features are described in terms of structural blocks separated by major thrust faults, the Valmy and Scott Canyon, the Dewitt, and the Golconda blocks. Another block, the Antler, records warping along a northwesterly trend.

High-angle faulting occurred during all the periods of orogenic movement. Because the Paleozoic and Mesozoic highangle faults cannot be separated in most places, they are described together. The high-angle faults formed in Tertiary and Quaternary time can be divided into four subgroups: those that contain dikes, those that contain ore deposits, those that cut the ore deposits, and, last, the range-front faults, which outline Battle Mountain.

The ore deposits in the Battle Mountain district are mainly in the Copper Canyon, Galena, and Copper Basin areas. The deposits include copper, lead-zinc, gold, silver, and antimony, of which the first three have yielded more than 90 percent of the total production. The recorded production through 1961 totals 150,282 ounces gold, $2,130,827$ ounces silver, $31,826,834$ pounds copper, $3,275,600$ pounds zinc, and $10,047,838$ pounds lead. The total dollar value of these metals is about thirteen million.

Mining began in Battle Mountain during the 1860's and has continued intermittently to the present. The first deposits mined between 1862 and 1900 included high-grade silver and copper ores. After 1900, there was little activity in the district, except for small-scale gold placer operations, until 1916 when copper ore shipments began; these shipments continued until 1922, then they diminished until the late 1920's when high copper prices again stimulated operations. During the 1930's, small-scale placer gold operations were carried on at many places. In 1941 a mill was installed at Copper Canyon and large-scale copper production began; in 1948 the mill was shifted to lead-zinc production and in 1954 was changed back to copper.

The ore bodies in the district are arranged zonally around the major intrusive areas. Copper-gold and gold-silver ore deposits lie in the central zone, lead-zinc-silver in the middle zone, and silver and antimony bodies in the outer zone. The mineral zones overlap to some extent, but on the whole they are spatially distinct.

The principal types of deposits in the district are (1) coppergold replacement bodies, (2) supergene copper deposits, (3) copper-gold-bearing veins, (4) lead-zinc-silver replacement bodies, (5) lead-zinc-silver veins, (6) silver veins, (7) goldsilver veins, and (8) antimony veins.

The most productive deposits have been copper-gold replacement bodies that ranged from a few feet to 400 feet long and were as much as 60 feet thick. The Copper Canyon ore bodies are the principal representatives of this type. The ore minerals are arsenopyrite, pyrrhotite, pyrite, chalcopyrite, galena, sphalerite and minor amounts of molybdenite and scheelite. Gangue minerals are calcium and magnesium silicates, siderite, quartz, calcite, and barite. The ore mined averaged about 1 percent copper, 1.5 ounces silver, and 0.10 ounce gold to the ton. The ore was localized along fractured zones in the calcareous unit that forms the lower part of the Battle Formation. The coppergold veins are similar in mineralogy to the replacement deposits but lack molybdenite and scheelite; quartz is the principal gangue mineral. In places where the ore is enriched, supergene copper bodies have been formed; chalcocite, cuprite, and covellite are the predominant ore minerals; and in the oxidized zone chrysocolla, malachite, and azurite predominate.

Gold-silver deposits and gold-silver veins, which occur in the peripheral part of the copper-gold zone, are similar in mineral- ogy but are relatively higher in gold and silver. The Buzzard, Gold Cash, and Plumas mines are typical of this group. The ore bodies mined were mainly enriched bodies where gold and silver were concentrated by leaching.

Lead-zinc-silver replacement bodies were mined in Copper Canyon, Iron Canyon, and near Galena. At the Copper Canyon mine in the lead-zinc-silver replacement bodies the ore minerals are mainly galena, sphalerite, pyrrhotite, pyrite, and minor amounts of chalcopyrite. The ore averaged 1.5 percent lead, 1.2 percent zinc, and 2.0 ounces silver and 0.06 ounce gold to the ton. In all, about 300,000 tons was mined from the largest, the Hornfels ore body. The lead-zinc-silver ore bodies at Iron Canyon and near Galena were higher in grade, but the ore bodies were smaller and ore production ranged from a few tons to a few hundred tons. The lead-zinc-silver veins, which are similar in mineralogy to the replacement bodies, generally follow fault zones. The Trinity (Armor) vein is typical of this group.

Silver-bearing veins, such as the Little Giant vein, are composed mainly of pyrite, galena, tetrahedrite, secondary proustite, pyargyrite, polybasite, boulangerite, and native silver. The ore mined was high grade, but the ore bodies were small and shallow.

Antimony ore has been mined at the Antimony King mine and Apex Antimony mine. The ore bodies are composed of stibnite and antimony oxides and occur in fault zones. The tonnage shipped was high grade but amounted to only about 200 tons.

Deposits containing bismuth and tellurium have been found in the quadrangle but have not been productive.

\section{INTRODUCTION}

The Antler Peak quadrangle covers the area bounded by meridians $117^{\circ} 00^{\prime}$ and $117^{\circ} 15^{\prime}$ and parallels $40^{\circ} 30^{\prime}$ and $40^{\circ} 45^{\prime}$; it includes Battle Mountain, the low foothills on its flanks, and parts of Buffalo Valley and Reese River and Humboldt River valleys. The town of Battle Mountain is 4 miles northeast of the range (fig. 1). The Battle Mountain mining district, the major producing district in this part of Nevada, covers the range and includes the Copper Canyon, Copper Basin, Galena, Iron Canyon, Snow Gulch, and Elder Creek areas. The main lines of the Southern Pacific Railroad and U.S. Highway 40 pass through the town of Battle Mountain and the northeastern corner of the quadrangle; the Western Pacific Railroad is 6 miles north of the northern border of the quadrangle. An asphalt-surfaced road extends from Battle Mountain southwestward along the east side of the range, and secondary gravelled roads extend from this road into Cottonwood, Galena, and Copper Canyons. Connecting roads that are, for the most part, unimproved have been built to mining properties. Only one road crosses the range; it is not shown on the topographic map but extends from the Antimony King mine westward past the Lucky Strike mine, then continues down the North Fork to the Oyarbide Ranch. The road shown on the map from Long Canyon to Cottonwood Creek no longer exists. 

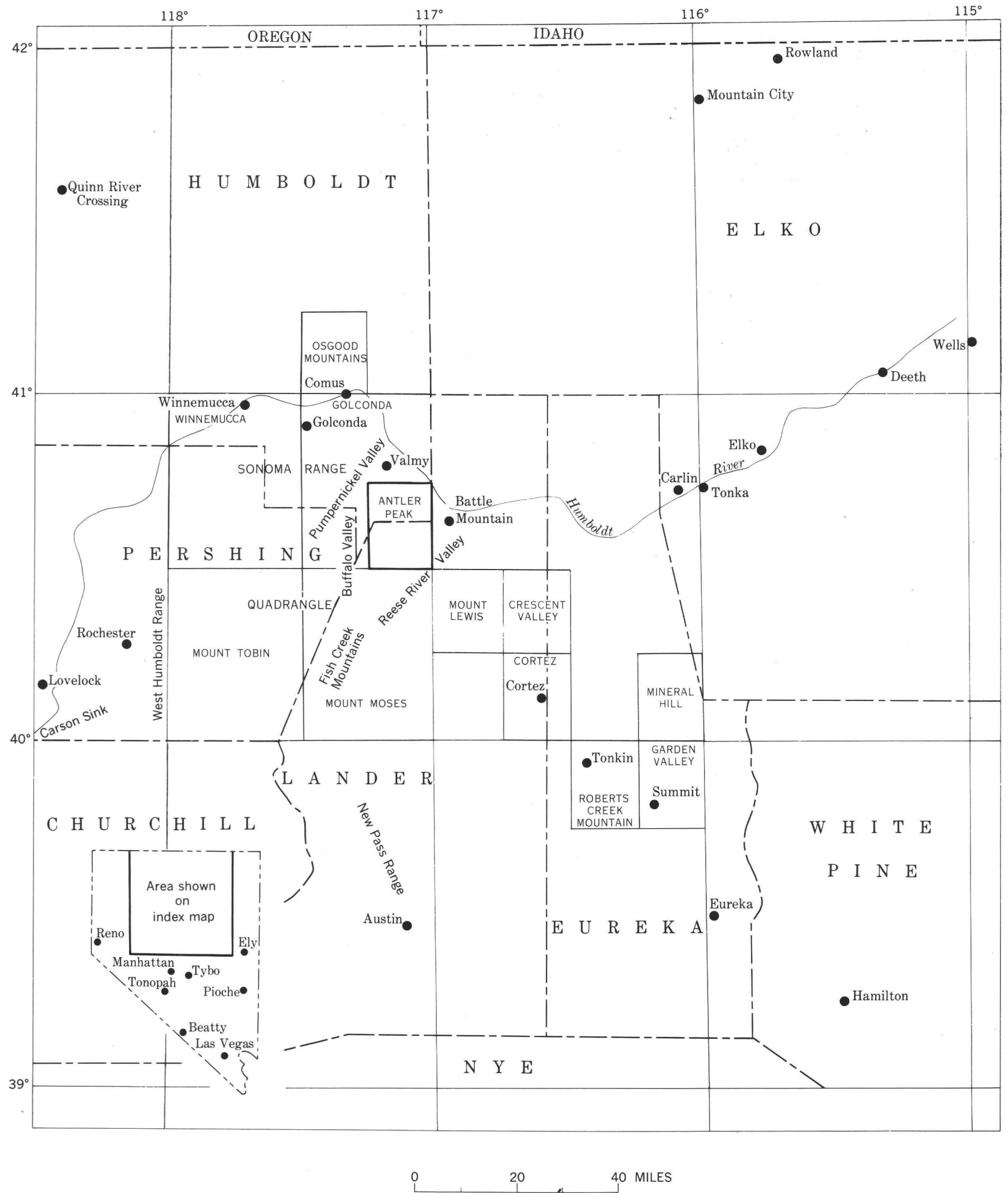

Figure 1.-Index map of north-central Nevada. 


\section{PHYSICAL FEATURES}

Battle Mountain is one of the ranges in the northcentral part of the Basin and Range province and is surrounded by alluviated valleys. Except for low hills in the southwestern, eastern, and southern parts of the range, the range is entirely within the boundaries of the Antler Peak quadrangle. The main axis of the range strikes northward, parallel to the general trend of the major ranges in this part of Nevada.

Battle Mountain is bounded on the west by Buffalo Valley, on the south and east by the Reese River valley, and on the north by the Humboldt River valley. The highest peak is North Peak, 8,550 feet above sea level. Antler Peak, which gives the quadrangle its name, is the next highest point, rising to 8,236 feet. The lowest point in the quadrangle is the valley of the Humboldt River at an altitude of 4,468 feet in the northeastern part of the quadrangle. The maximum relief is 4,082 feet, but the local relief is less; near North Peak it is 3,500 feet, but elsewhere it is generally less than 2,000 feet. The west and north slopes of the range are extremely rugged, but the south and east sides are less precipitous and slope smoothly down to the valleys.

\section{CLIMATE}

The climate in this part of Nevada is arid, and the valleys normally receive only about 6 inches of rainfall annually; at Battle Mountain (alt. 4,513 ft) rainfall ranges from about 3 to 14.0 inches (Waring, 1918, p. 102-104). Most of the precipitation falls during the winter and spring months, largely as snow in the mountains and as rain and light snows in the valleys. During some years heavy rainfall has been recorded in June and September, but only local showers fall during July and August. Rainfall at higher altitudes is greater and averages about 12 inches annually at Austin (alt. 7,000 $\mathrm{ft}$ ), 80 miles to the south of Battle Mountain (Sager, 1941, p. 979).

The maximum temperature recorded at Battle Mountain is $112^{\circ} \mathrm{F}$ and the minimum $-40^{\circ} \mathrm{F}$. The January average is $28.4^{\circ} \mathrm{F}$, and the $\mathrm{July}$ average is $74.7^{\circ} \mathrm{F}$.

\section{WATER SUPPLY}

The water supply of the Battle Mountain area is partly derived from surface water and partly from ground water. The surface-water supply includes the Humboldt River, the small streans that head in Battle Mountain, and springs in and near the range. Because the rate of flow of all these streams is highly variable, depending upon the season, the principal water supply is gained by wells from the ground water in the valleys.

There are three major ground-water basins in the Battle Mountain area: Buffalo Valley on the west,
Reese River valley on the east, and the Humboldt River valley on the north. Little is known as to the configuration of the basins, but according to Waring (1918, p. 110), these valleys are deeply filled with unconsolidated deposits in which ground water occurs. Within the lower parts of these valleys, the water table is within 10 feet of the surface, and there are flowing wells at the town of Battle Mountain and at several places in Reese River valley. Scant data indicates that the water table rises gradually toward the ranges, but at a lower gradient than the surface gradient.

Most of the wells dug in Buffalo Valley are shallow and are not heavily pumped. Mining operations in Copper Canyon and on the Copper Canyon fan required large amounts of water, and deep wells were accordingly put down south of the canyon mouth just outside the quadrangle boundary. The collar elevations ranged from 4,624 to 4,667 feet, and the water table ranged from 4,619 to 4,625 feet. The water-bearing units are mainly coarse gravel layers which are interbedded with silts and clays. According to Waring (1918, p. 113114 ), many of the wells drilled in the Reese River valley have only small flows because the water-bearing beds are fine sands. A few have a small artesian head.

At Battle Mountain some wells at one time yielded an artesian flow, but as water use increased through pumping, the flow from these ceased. Originally there were four horizons of flowing water, at depths of 100, 180, 250 , and 300 feet.

Analyses of water from wells and springs in the area show that quality of the water is good (table 1). The water is satisfactory for domestic use and for irrigation, but generally requires treatment for industrial use. In boilers the water would, in general, cause incrustation and foaming, and water from some wells would be corrosive.

\section{PREVIOUS WORK}

The first systematic geologic study of the Battle Mountain area was made by Hague and Emmons (1877, p. 666-672) under the direction of Clarence King. Emmons visited most of the operating mines and contributed significant information on early day mining. James M. Hill was the next geologist to work in the area (1915, p. 64-91). In 1913 he examined most of the mines and made extensive notes on the geology of the adjacent areas. The writers have drawn on Hill's report for descriptions of several mines that were inaccessible during the time of the present study. In 1930 Frank C. Schrader visited the active mines in the district, and in 1932 he wrote a short report on the mining activity. This report was never published but was available to the present authors and has been the source of much pertinent data. In addition, many geologists 
TABLE 1.-Typical analyses, in parts per million, of water from wells and springs in the Battle Mountain area [From Waring, 1918, p. 124-125]

\begin{tabular}{|c|c|c|c|c|c|c|c|c|c|c|}
\hline Well or spring & $\begin{array}{l}\text { Silica } \\
\left(\mathrm{SiO}_{2}\right)\end{array}$ & Iron $(\mathrm{Fe})$ & $\underset{\text { Calcium }}{\text { C(a) }}$ & $\underset{(\mathrm{Mg})}{\text { Magnesium }}$ & $\begin{array}{l}\text { Sodium and } \\
\text { potassium } \\
(\mathrm{Na}+\mathrm{K})\end{array}$ & $\begin{array}{c}\text { Carbonate } \\
\text { radical } \\
\left(\mathrm{CO}_{3}\right)\end{array}$ & $\begin{array}{c}\text { Bicarbonate } \\
\text { radical } \\
\left(\mathrm{HCO}_{3}\right)\end{array}$ & $\begin{array}{l}\text { Sulfate } \\
\text { radical } \\
\left(\mathrm{SO}_{4}\right)\end{array}$ & $\underset{(\mathrm{Cl})}{\text { Chloride }}$ & $\begin{array}{l}\text { Totaldissolve } \\
\text { solids at } 180^{\circ} \\
\text { C }\end{array}$ \\
\hline $\begin{array}{l}1 \\
2 \\
3 \\
4\end{array}$ & $\begin{array}{l}70 \\
65 \\
35 \\
23\end{array}$ & $\begin{array}{c}\text { Trace } \\
\text { do }\end{array}$ & $\begin{array}{r}40 \\
30 \\
123 \\
31\end{array}$ & $\begin{array}{l}11 \\
1.0 \\
36 \\
27\end{array}$ & $\begin{array}{r}35 \\
50 \\
82 \\
488\end{array}$ & $\begin{array}{r}0.0 \\
.0 \\
168.0\end{array}$ & $\begin{array}{l}142 \\
162 \\
398 \\
317\end{array}$ & $\begin{array}{r}45 \\
30 \\
227 \\
264\end{array}$ & $\begin{array}{r}41 \\
17 \\
50 \\
307\end{array}$ & $\begin{array}{r}340 \\
298 \\
750 \\
1,388\end{array}$ \\
\hline
\end{tabular}

1. Land Development Co., Home Ranch, Humboldt Valley, 1 mile north of the

2. Farris Ranch, Humboldt Valley, 21/2 miles east of the town of Battle Mountain.

and engineers have published accounts of mining operations in the district which also have been drawn upon by the authors.

\section{FIELDWORK AND ACKNOWLEDGMENTS}

The Antler Peak project was part of the Sonoma Range project, which was begun under the direction of H. G. Ferguson in 1939. Because the major ore producing deposits were in Battle Mountain, the Antler Peak quadrangle was topographically mapped at a scale of $1: 62,500$ to give a base map for study of the mining areas. The Antler Peak project was supervised by $\mathrm{Mr}$. Ferguson, who also participated actively in the early stages of the field work. His broad experience, gained from studies of the geology of central and western Nevada, was of inestimable value in interpretation of the stratigraphic and structural problems observed in the quadrangle.

Mapping in the Antler Peak quadrangle was begun in June 1941 and continued, with interruptions, until October 1942. After a delay caused by World War II, fieldwork was resumed in July 1946 and continued at intervals through the seasons of 1952 and 1953.

For varying periods of time, Claude C. Albritton, Wilfred J. Carr, Calvin C. Covell, Manning W. Cox, Arthur E. Granger, J. Frederick Maier, Paul D. Proctor, James A. Rhodes, John L. Rich, J. F. Robertson, Edgar A. Scholz, Bryan Sorenson and Fred Stehle assisted in the fieldwork. David C. Arnold was responsible for mapping the mines of the Elder Creek area, for the geochemical sampling, and mapping of the metamorphic zones, and in addition, he assisted in geologic and underground mapping and with petrographic work in the office.

James Steele Williams, Lloyd G. Henbest, Mackenzie Gordon, Jr., and Helen Duncan, all of the U.S. Geological Survey, visited the project area and, in addition to making the determinations of the fossils collected, made available information on the succession of Paleozoic rocks elsewhere in the Western States. Raymond Douglass, Josiah Bridge, W. H. Hass, C. W. Merriam, R. J. Ross, Jr., W. B. N. Berry, and Allison R. Palmer
3. Wilson Spring, Battle Mountain, mouth of Galena Canyon.
4. Picketts Spring, north end Fish Creek Mountains, Buffalo Valley.

also reported on fossils collected in the area. R. A. Gulbrandsen and Charles Milton assisted in mineral determinations.

The writers also owe a debt of gratitude to members of the U.S. Geological Survey who have worked in nearby areas and have exchanged visits and discussed problems of mutual interest. Among these are H. G. Ferguson, Olcott Gates, James Gilluly, Preston E. Hotz, Keith Ketner, S. W. Muller, Roger S. Morrison, J. Fred Smith, Don E. White, P. E. Cloud, and S. Warren Hobbs.

Geologists of the Southern Pacific Land Department carried on an extensive mapping program in Battle Mountain in 1957-59 under the direction of George A. Kiersch to appraise the mineral resources. The writer has drawn on the detailed maps prepared by Frank Stejer, John T. Collier, and Robert F. Wilson for additions and modifications of the geologic map of the quadrangle.

It is a pleasure to acknowledge the cooperation and hospitality of Robert H. Raring, formerly General Manager of the Copper Canyon Mining Co. Permission was given to map the underground workings on property of the company, and all geologic data in files of the company were made available to the U.S. Geological Survey. The helpful cooperation of all the members of Mr. Raring's staff, especially Ralph Hayden, L. W. Snow, and William D. Kerns, is also acknowledged.

In addition, the following cooperated in furnishing valuable data: Fred Baldini, Charles Caldwell, Bonner Cole, Lee Hand, G. C. Hinman, Frank Keever, Ed Lauritzen, Gordon Estes, Harry Lauritzen, Dudley Wilson, Al Layton, Horace Dolezal, D. B. Potter, William Swackhamer, Bruce Swackhamer, Marion Fisher, Louis Lemaire, René Lemaire, D. F. Shovelin, H. B. Chessher, Eric Sonderman, E. Hider, N. Pesi, and Leon Belaustegui, Gertrude Burridge, James Bennett, Petra Mendive, Margaret O'Leary, Nellie Adams, Emil Balch, W. G. Lee, W. O. Broyles, and Claude Post.

The writers are also indebted to W. P. Hewitt and Samuel Bowditch of the American Smelting and Refining Co. for helpful discussions in the field; to R. E. Welch for permission to use maps of the Buzzard and 
Iron Canyon mines; to J. A. Hogle and S. B. Hinckley for maps of the Nevada mine; and to James Wilson of the Anaconda Copper Co. for stimulating discussions of district problems.

John E. Frost, Robert C. James, and associates of the Duval Corp. furnished information on recent development work being done in the district.

\section{REGIONAL SETTING}

In eastern Nevada, Paleozoic rocks of Cambrian to Mississippian age are composed mostly of limestone and dolomite and minor amounts of shale and quartzite (Roberts and others, 1958, p. 2816). These rocks were deposited in a shallow water miogeosynclinal environment and are referred to as the carbonate assemblage. In western Nevada, rocks of the same time span are predominantly clastic sediments, chert, and intercalated volcanic rocks; these rocks are called the siliceous and volcanic assemblage. Locally, a transitional assemblage is present that includes elements of both the eastern and the western types.

The broad geosyncline in which the three assemblages were laid down persisted with local disturbances until Late Devonian time, when orogenic movements began along a north-trending positive area (Nolan, 1928, p. 161). Those orogenic movements ultimately caused formation of a belt of rugged highlands - the Antler orogenic belt-between the $116^{\circ}$ to $118^{\circ}$ meridians (Roberts, 1949a, 1949b, 1951). This belt was the locus of intense folding and faulting that culminated in the Roberts Mountains thrust fault in Mississippian time. During the orogenic movements, which lasted until Early Pennsylvanian time, a broad apron of coarse clastic rocks was laid down over central and eastern Nevada. Away from the orogenic belt, the clastics grade laterally into finer sediments and limestone of the normal marine section. The clastic rocks constitute a distinct facies which has been named the overlap assemblage. Following the Antler orogeny, north-central Nevada remained partly above sea level; clastics derived from the uplands were deposited in local straits and embayments along with thin limestone units.

\section{GENERAL GEOLOGY}

\section{SEDIMENTARY ROCKS}

The sedimentary rocks of Paleozoic age in the Antler Peak quadrangle include rocks of the siliceous and volcanic, transitional, and overlap assemblages and the Havallah sequence (pl. 1). The siliceous and volcanic assemblage is represented by the Scott Canyon and Valmy Formations; the transitional assemblage by the Harmony Formation; and the overlap assemblage by the Antler sequence, which includes the Battle Forma- tion, Antler Peak Limestone, and Edna Mountain Formation. The Havallah sequence does not belong to any of these assemblages; it is a western correlative of the Antler sequence and includes the Pumpernickel and Havallah Formations which were deposited in western Nevada and were brought into this area on the Golconda thrust fault.

The siliceous and volcanic and transitional assemblages are separated by major thrust faults (pl. 2); because parts of many units are cut out by the thrusts, no accurate idea of the total thickness of the Paleozoic section can be given. It is estimated that the composite stratigraphic section in the quadrangle is at least 30,000 feet thick and may be thicker.

These units are given in table 2 and are described briefly in this part of the report on the Antler Peak quadrangle. For more complete discussions of the distribution, lithology, structural and stratigraphic relations, age, and correlation of the units, "Stratigraphy and structure of the Antler Peak quadrangle, Nevada" (Roberts, 1964) should be consulted.

\section{SILICEOUS AND VOLCANIC ASSEMBLAGE} CAMBRIAN SYSTEM

SCOTT CANYON FORMATION

The oldest formation in Battle Mountain is the Scott Canyon Formation, which underlies most of the southeastern part of the range; the type locality is in Scott Canyon, a tributary of Galena Canyon. The Scott Canyon Formation is composed predominantly of chert, argillite, and greenstone, and minor amounts of sandstone and quartzite; rough estimates made from cross sections indicate that the aggregate thickness may be more than 5,000 feet. The chert units are thin- to medium-bedded in layers an inch to 18 inches thick and contain thin shale partings. They are mostly gray, green, brown, or black but are locally white or tan. The argillites are commonly gray, brown, or black.

The greenstones include massive lavas, pillow lavas, and pyroclastics that probably represent submarine eruptions, as they are intercalated with the sedimentary rocks. The feldspars of the greenstones have been albitized and the mafic minerals altered to chlorite, epidote, and zoisite.

The sandstone beds are feldspathic and contain fragments of chert and volcanic material. The quartzite beds near the Butte mine are dark gray to black and resemble the quartzite of the Valmy Formation.

The Scott Canyon Formation contains an archaeocyathid fauna considered by Helen Duncan of the U.S. Geological Survey to be of late Early or early Middle Cambrian age. Partly correlative units are the Osgood Mountain Quartzite and Preble Formation in 
TABLE 2.-Summary of the sedimentary rocks of Paleozoic age, Antler Peak quadrangle

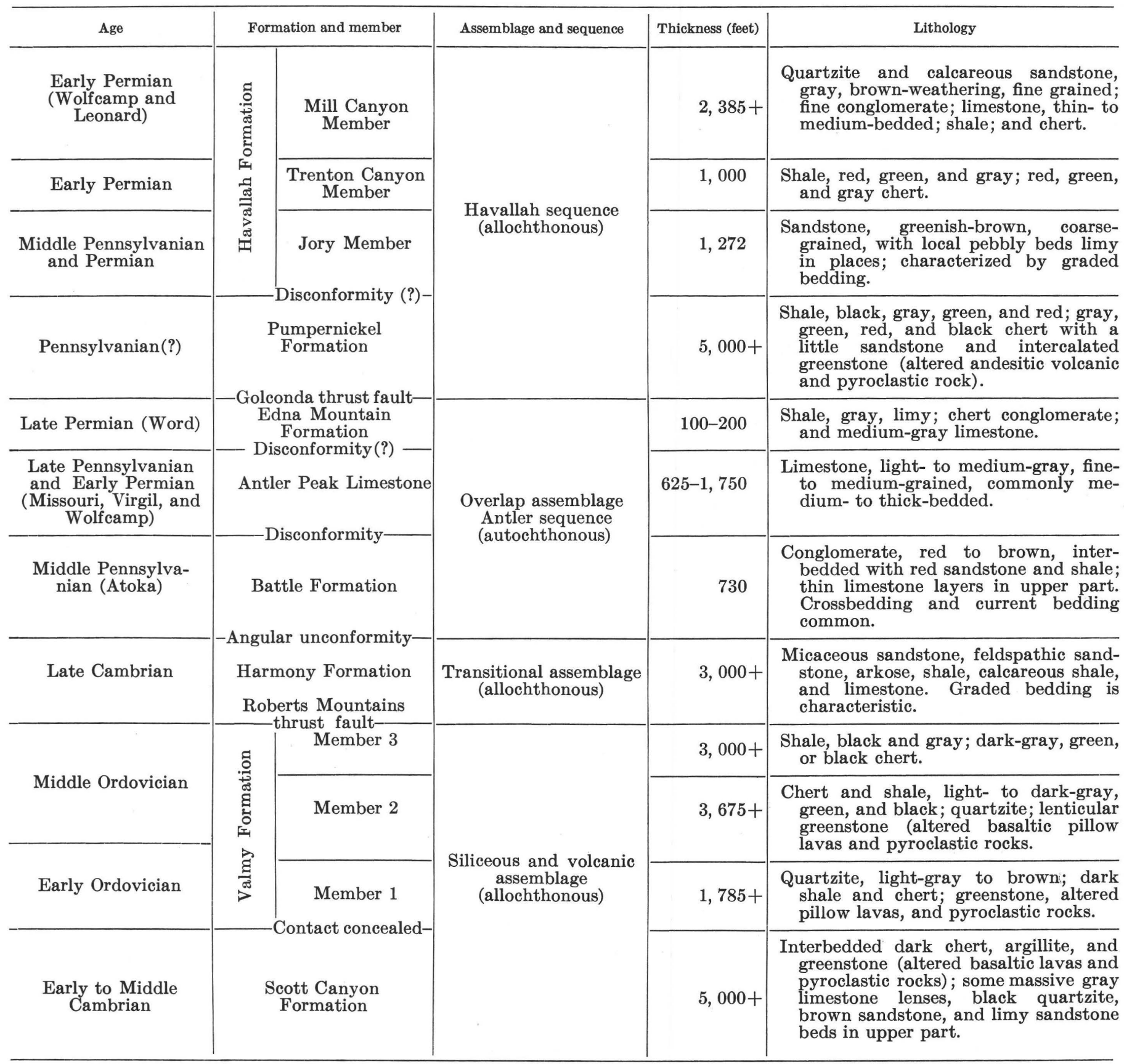

the Osgood Mountains (Hotz and Willden, 1964, p. 7-13) and Cambrian strata near Barrel Spring, 16 miles south of Silver Peak, Nev. (Walcott, 1908, p. 189).

\section{ORDOVICIAN SYSTEM}

\section{VALMY FORMATION}

The Valmy Formation, which underlies most of the northwestern part of the quadrangle, has been divided into three members : the oldest consists mainly of gray quartzite, chert, and shale and some greenstone; mem- ber 2 is largely interbedded shale and chert and greenstone, but it contains thick quartzite units at the base and top; and member 3 is composed of chert, shale, and a little greenstone. As all these units are intensely deformed, no accurate measurements of thickness have been made, but it is estimated that they aggregate more than 8,400 feet.

Collections of graptolites from the Valmy Formation have been studied by Josiah Bridge, R. J. Ross, Jr., and W. B. N. Berry. These collections indicate that the 
lower member is Early Ordovician and that members 2 and 3 are Middle Ordovician in age. Partly correlative formations are the Vinini Formation in the Roberts Mountains area (Merriam and Anderson, 1942, p. 1694) and the Comus Formation in Edna Mountain and the Osgood Mountains (Hotz and Willden, (1964, p. 2021).

\section{TRANSITIONAL ASSEMBLAGE CAMBRIAN SYSTEM}

HARMONY FORMATION

The Harmony Formation underlies the eastern and northeastern parts of Battle Mountain. It is in the upper plate of the Dewitt thrust, which overrides the Scott Canyon and Valmy Formations. The Harmony Formation is composed of interbedded sandstone, feldspathic sandstone, arkose, pebbly sandstone, shale, calcareous shale, and limestone. The proportion of these units is variable from place to place, but sandstone and feldspathic sandstone make up about 70 percent of the formation and calcareous shale and shale the bulk of the remainder. When fresh, the sandstones are commonly dark green and weather brownish green to brown. The shales are generally green or brown on fresh surfaces but include gray, red, and black units. Near granitic intrusives, the shales are metamorphosed to dark hornfels and the sandstones to quartzite. The Harmony locally contains ore bodies in Copper Basin and in Copper Canyon.

The Harmony Formation was derived from a Precambrian granitic and metamorphic terrain. Graded beds are common in the sandy units, and features typical of shallow water deposition are absent; such evidence suggests deposition by density currents (Kuenen, 1953, p. 1045).

No fossils have been found in the Harmony Formation in Battle Mountain, but Hotz and Willden (1964, p. 18, 19) collected trilobites of Late Cambrian age from the Harmony in the Osgood Mountains. A correlative fauna is found in the Windfall Formation of the Eureka district (Nolan, Merriam, and Williams, 1956, p. 19, 20).

\section{OVERLAP ASSEMBLAGE}

After the Antler orogeny, coarse clastics were shed both eastward and westward from the orogenic belt into flanking seas and locally into straits and embayments within the belt; thus, the clastics overlap the rocks previously deformed. These rocks were named the overlap assemblage (Roberts and Lehner, 1955, p. 1661) and are represented in Battle Mountain by the Antler sequence, which includes the Battle Formation, Antler Peak Limestone, and Edna Mountain Formation.

\section{ANTLER SEQUENCE}

BATTLE FORMATION

The oldest unit of the Antler sequence is the Battle Formation, which is the host rock for the most productive ore bodies in the district. It crops out in an erosional remnant in Copper Basin, in fault slivers in Rocky and Trenton Canyons, and in a belt as much as a mile wide extending northwesterly across the quadrangle.

At the type section east of Antler Peak, the Battle Formation has been subdivided into three parts: the lower part (398 ft thick) is mostly medium- to thickbedded boulder to cobble conglomerate, commonly deep red where unmetamorphosed; the middle part $(74 \mathrm{ft}$ thick) consists largely of pebble and granule conglomerate interbedded with sandstone, shale, calcareous shale, and limestone; the upper part (258 $\mathrm{ft}$ thick) is composed of interbedded fine sandstone, pebble conglomerate, and shaly beds.

The Battle Formation rests unconformably on rocks of the Scott Canyon, Valmy, and Harmony Formations, and in most areas throughout the quadrangle it dips westward at low angles and overlaps folds and thrust faults in the older rocks. It was derived from an adjacent area of high relief and was transported into its depositional basins by streams of high competence.

The limestone units in the Battle Formation, according to Lloyd Henbest, contain fusulinid faunas of early Middle Pennsylvanian (Atoka) age. Correlative beds in eastern Nevada include the Ely Limestone and Moleen and Tomera Formations of Dott (1955, p. $2234)$; in Edna Mountain the Highway Limestone contains equivalent fusulinids.

\section{ANTLER PEAK LIMESTONE}

The Antler Peak Limestone rests disconformably on the Battle Formation and is coextensive with the Battle throughout most of the quadrangle. The type section is on Antler Peak where it has a maximum thickness of 625 feet; the beds are mostly medium to thick bedded. On fresh surfaces the limestone is light to dark gray and commonly weathers medium gray. Some shaly and sandy units weather tan to brown. In Copper Basin the lower beds are absent, but higher units of tan-weathering shaly limestone and dolomite are present; the total thickness here is estimated to be about 1,750 feet.

A varied fusulinid, coral, and brachiopod fauna in the lower beds has been assigned by Lloyd Henbest, Raymond Douglass, James Steele Williams, and Wilbur H. Hass to Late Pennsylvanian (Missouri and Virgil) and early Permian (Wolfcamp) time. Cor- 
relative beds in eastern Nevada are found in the Strathearn Formation (Dott, 1955, p. 2254, 2255).

EDNA MOUNTAIN FORMATION

The Edna Mountain Formation, which rests disconformably on the Antler Peak Limestone, is exposed in only a few places in the quadrangle, mostly just below the Golconda thrust in Galena and Copper Canyons. It is composed of interbedded limy shale, limestone, sandstone, and chert pebble conglomerate that may aggregate as much as 200 feet in the quadrangle.

Brachiopod collections made by James Steele Williams from the Edna Mountain Formation near the Nevada mine were considered partly correlative with the Phosphoria and Gerster Formations (Word) of eastern Nevada and Utah.

\section{HA VALLAH SEQUENCE}

The Havallah sequence contains the Pumpernickel and Havallah Formations, which are roughly correlative with the units of the Antler sequence, but were deposited in a seaway west of the Antler orogenic belt and were brought into this area on the Golconda thrust in Late Permian time.

\section{PUMPERNICKEL FORMATION}

The Pumpernickel Formation crops out in a belt 1 to 2 miles wide that extends northward through the quadrangle from Willow Creek to the vicinity of the Marigold mine. The base of the unit has not been seen; where mapped, it rests on the Golconda thrust throughout the region. The Pumpernickel Formation consists mostly of chert, argillite, and siliceous argillite, but it contains some greenstone flows and pyroclastics in the upper part. The chert and argillite are mostly green, gray, brown, purple, or black. The argillite weathers to smooth slopes broken by more resistant siliceous argillite and chert units. Estimates of the thickness of the formation indicate that the beds total at least 5,000 feet.

The Pumpernickel Formation has yielded only a sparse conodont fauna. W. H. Hass assigned this fauna to the Middle Pennsylvanian (Des Moines), but inasmuch as this age assignment conflicts with the age of the basal unit of the overlying Havallah, the Pumpernickel will be considered Pennsylvanian(?) until this conflict is resolved.

\section{HAVALLAH FORMATION}

The Havallah Formation, which underlies the western part of Battle Mountain, rests with possible disconformity on the Pumpernickel Formation. The Havallah has been divided into three units in the quadrangle: The oldest, the Jory Member, about 1,270 feet thick, consists of pebbly sandstone, sandstone and inter- bedded minor conglomerate, shale and chert. The middle member, the Trenton Canyon Member, is mainly interbedded red, green, purple, or gray shales and chert beds that total about 1,000 feet in thickness; the youngest, the Mill Canyon Member, about 2,385 feet thick, is more varied in lithology and is composed of interbedded quartzite, limy sandstone, chert, shale, and sandy limestone and a little chert conglomerate. The sandstone and quartzite units are commonly gray on fresh surface and weather tan to brown; the limestones are generally dark where fresh and weather light to medium gray.

The Jory Member lacks features suggesting deposition in shallow water but has distinctive sole markings suggesting that it was deposited below wave base by density currents from the north or south. The Mill Canyon Member shows sedimentary structures suggestive of deposition in shallow water; possibly the depositional basin gradually shallowed during later Havallah time.

The lower part of the Jory Member contains fusulinids of early Middle Pennsylvanian (Atoka) age and the upper part contains fusulinids of Early Permian age (Lloyd Henbest and Raymond Douglass, written communication, 1953). The A tok a fusulinids are abraded, suggesting redeposition from older beds, and are not necessarily diagnostic as to the age of the Jory Member. Pending further study of the faunas, the Jory Member is considered to be of middle Pennsylvanian and Permian age. The Trenton Canyon Member has not yet yielded fossils; according to Raymond Douglass, the Mill Canyon Member has yielded fusulinids of Early Permian (Wolfcamp and Leonard) age.

\section{QUATERNARY SYSTEM}

Battle Mountain is mantled on all sides by Quaternary deposits, which have been divided into five units: older gravels, older alluvium, younger alluvium, shoreline deposits, and flood plain deposits.

Older gravels.-The older gravels are scattered gravel patches that are generally above the present alluvial fans on the periphery of the range and in the range. They are mostly well-washed and fairly well rounded cobbles and boulders, mainly of quartzite and chert, formed during early stages of the uplift of the range.

Older alluvium.-The older alluvium that makes up the alluvial fans is mainly unsorted coarse gravel having a sandy and clayey matrix. The gravel is composed of angular fragments near the range and contains boulders ranging up to 5 feet in their longest dimension; away from the range the fragments gradually become smaller and more rounded. The lower parts of the fans in some valleys, such as Copper Canyon, con- 
tained enough gold to warrant placer operations; mining has been carried on by drifting along bedrock and by dredging.

Younger alluvium.-Younger alluvium veneers the floors of valleys that have been incised in the fans and valley fill and also forms the alluvial aprons covering the lower parts of the fans.

Shoreline deposits.-Shoreline gravels have been found in several pits near the town of Battle Mountain. The gravels are overlain by river deposits and presumably indicate a pre-Lahontan lake in this area.

Flood-plain deposits.-Flood-plain deposits of the intermontane valleys consist of white or light gray to buff silts that intertongue with the fans. Locally the silts have been transported by wind.

\section{IGNEOUS ROCKS}

The igneous rocks in the Antler Peak quadrangle are volcanic and intrusive rocks that range in age from Cambrian to late Tertiary or early Quaternary. The oldest igneous rocks are mafic andesite or basalt flows, pillow lavas, and pyroclastics intercalated with sedimentary rocks of Paleozoic age. Such igneous rocks make up a large part of the Scott Canyon Formation of Cambrian age, and similar ones were also extruded in the Ordovician during Valmy time and in the Pennsylvanian (?) during Pumpernickel time. Diabase sills and dikes cut the rocks of the Harmony Formation, but no related flows have been recognized. The major period of intrusive activity was probably during the early Tertiary when magma, mainly of quartz monzonitic and granodioritic composition, invaded all the older rock units in the quadrangle. The youngest igneous rocks include welded and nonwelded tuffs of quartz latitic composition and olivine basalt flows of late Tertiary and early Quaternary age.

\section{IGNEOUS ROCKS OF PALEOZOIC :AGE}

The igneous rocks of Paleozoic age are mainly mafic flows, pillow lavas, and pyroclastics that were either extruded on the sea floor or on nearby land areas and were subsequently carried into ocean basins. The igneous rocks are intercalated with chert and clastic sedimentary rocks and form a typical eugeosynclinal sequence.

Associated with the volcanic rocks are related mafic intrusive bodies of gabbro and diabase which are mainly dikes, sills, and small plugs.

\section{INTRUSIVE ROCKS OF TERTIARY AGE} GRANODIORITE AND QUARTZ MONZONITE

The major intrusive bodies that have been mapped in the Antler Peak quadrangle are stocks of granodiorite and quartz monzonite. The principal stocks are in
Trenton Canyon, near the mouth of Elder Creek, in Snow Gulch and Copper Basin, and in Copper Canyon. Apophyses, dikes, and sills extend out from the stocks, and dikes and sills occur in separate masses throughout the quadrangle. Most of these intrusives are porphyritic and are made up of conspicuous phenocrysts of plagioclase, orthoclase, and quartz in a fine- to medium-grained groundmass. In the larger bodies, the central parts are generally equigranular and are medium to coarse grained. Two of the intrusive bodies have been dated as late Eocene to early Oligocene(?) by the lead-alpha method, and the others are probably of the same age.

Representative intrusive bodies are briefly described here; additional petrographic details and analyses are given in Roberts (1964, p. A51-A62).

Granodiorite at Trenton Canyon.-The granodiorite stock at Trenton Canyon is about 2 miles long and as much as a mile wide. The peripheral parts of the stock are porphyritic and consist of phenocrysts of feldspar and quartz set in a groundmass of quartz, feldspar, biotite, and hornblende. The central parts of the intrusive are generally equigranular and have an average grain size of about $2 \mathrm{~mm}$. The feldspars include both plagioclase and orthoclase. The plagioclase is mainly in subhedral-zoned crystals $\left(\mathrm{An}_{45-20}\right)$; the orthoclase occurs in two generations, as large crystals up to $3 \mathrm{~mm}$ long and in fine-grained intergrowths containing quartz in the groundmass (Roberts, 1964 figs. 24 and 25). Quartz is present also in two generations, as early subhedral bipyramidal crystals as much as $3 \mathrm{~mm}$ long and as anhedral crystals averaging about $0.5 \mathrm{~mm}$ in diameter in the groundmass. The mafic minerals are biotite and hornblende, which together make up about 5 percent of the rock. The accessory minerals are sphene, apatite, zircon, and magnetite partially altered to hematite.

Quartz monzonite at Copper Canyon.-The quartz monzonite stock at Copper Canyon is about threefourths of a mile long and half a mile wide. It is conspicuously porphyritic and contains phenocrysts of plagioclase, quartz, biotite, and less commonly orthoclase. The plagioclase phenocrysts show oscillatory zoning in the range of $\mathrm{An}_{50-30}$. The orthoclase phenocrysts are partly perthitic. The quartz phenocrysts are mostly subhedral and bipyramidal. The groundmass is composed mostly of intergrown quartz and orthoclase but contains a few plagioclase and biotite crystals.

Dikes.-Dikes of granodiorite and quartz monzonite are widespread and are particularly abundant in the northeastern part of the quadrangle. These dikes appear to be genetically related to the stocks and represent 
offshoots from them. In addition, dikes of gabbro, diorite, quartz diorite, diabase, kersantite, and granite porphyry have been mapped and are shown on plate 1 .

\section{IGNEOUS METAMORPHISM}

The sedimentary and volcanic rocks of Paleozoic age in Battle Mountain have been cut by many intrusive bodies (pls. 1, 3). In their aureoles the sedimentary rocks have been metamorphosed, partly by heat and partly by the introduction of fluids derived from the igneous bodies and from related deeper sources. The metamorphism caused reconstitution of the original minerals in the sedimentary and volcanic rocks and in the igneous rocks as well. The changes in the aureoles are commonly called exomorphism, and the changes in the igneous bodies are called endomorphism. The formation of the ore deposits may be considered a late phase of igneous metamorphism and appears to have followed contact metamorphism without a significant break in time.

\section{METAMORPHISM OF THE IGNEOUS ROCKS}

The intrusive igneous rocks in the Antler Peak quadrangle have undergone endomorphic alteration that began at the time of consolidation and extended into the hydrothermal stage. The earliest stage of alteration was propylitization, which accompanied or was followed by potassic metasomatism and later by silicification. In igneous bodies far from areas of ore deposits, propylitization and potassic metasomatism are the only effects of endomorphic alteration, but near ore deposits silicification also is widespread.

Propylitization includes the alteration of the original biotite and hornblende to chlorite, epidote, clinozoisite, zoisite, and carbonate. In general, the hornblende has been more highly altered than biotite, and in some intrusive bodies fresh hornblende is difficult to find. In rocks that are highly propylitized, the feldspars are also likely to be somewhat kaolinized and sericitized, and pyrite is generally present also.

Potassic metasomatism during the late magmatic stage was accomplished by formation of orthoclase, sericite, muscovite, and biotite in the intrusive bodies and in the aureole rocks. Following the crystallization of the major silicate constituents, the potassium content was relatively enriched in the late magmatic liquid. This potassium-rich solution reacted with the earlier plagioclase and formed orthoclase that replaced it peripherally, along crystallographic planes, or adjacent to veinlets (Roberts, 1964, fig. 25) ; this is clearly shown by staining thin sections with sodium cobaltinitrite (Chayes, 1952). The late-stage orthoclase is finely granular like the orthoclase in the groundmass and ap$736-007$ O-65-2 parently crystallized at the same time. As shown in figure 25 of Roberts (1964), a plagioclase crystal, which was peripherally altered to an aggregate of orthoclase and sericite, continued to grow after alteration ceased and now has a clear rim. Such evidence indicates that the alteration was contemporaneous with late-stage crystallization. Further chloritization and sericitization also took place during this time, concomitant with the crystallization of late-stage minerals.

Silicification is mainly confined to the vicinity of the ore deposits. Elsewhere a few narrow quartz veins occur along fractures, but their bulk is small.

\section{METAMORPHIC ZONES}

An aureole of contact metamorphism surrounds the larger intrusive bodies. This aureole may be divided into an inner zone of intense metamorphism in which changes in the chemical composition of the rock are due to addition and loss of material, an intermediate zone in which recrystallization is the major effect of the metamorphism, and an outer zone in which the rocks are merely more indurated. The aureoles extend outward from the contacts from a quarter of a mile to nearly 2 miles (pl. 3). The width of the aureole appears to be related mainly to the composition of the intruded rock, but structural control was locally important; another significant factor was the composition of the metamorphosing solutions. On plate 3 the inner zone, which is only a few tens of feet wide in most places, is not shown; it is included with the intermediate zone which is indicated by stippling; the spacing of the dots is roughly proportional to the degree of metamorphism.

The intruded rocks most susceptible to metamorphism are the limy beds in the Battle, Harmony, and Havallah Formations and the cherty and shaly beds in the Scott Canyon, Pumpernickel, and Valmy Formations. Impure sandstones in the Harmony Formation that contain much clastic mica and feldspars were also highly susceptible to contact metamorphism. The structure of the rocks also influenced the extent of metamorphism; on the strike ridge west of Copper Canyon, the metamorphism was less extensive normal to bedding than parallel to bedding in the valley north of the main intrusive body. Owing to the complexities of the structure, such relationships are not so clear in most other places in the range.

The minerals of the inner zone in calcareous rocks include garnet, wollastonite(?), diopside, actinolite, tremolite, biotite, and orthoclase. In argillaceous rocks the minerals are biotite, muscovite, cordierite, orthoclase, and muscovite and sericite.

In the intermediate zone, calcareous rocks are metamorphosed to tremolite- and actinolite-bearing hornfels. 
Argillaceous rocks are metamorphosed to biotite hornfels.

Monomineralic rocks, such as limestone, quartzite, and chert, were changed somewhat by additive metamorphism in the inner zone, but except for recrystallization and induration, they are little changed in the intermediate and outer zones.

\section{METAMORPHISM OF THE SEDIMENTARY ROCKS}

The sedimentary rocks in the Battle Mountain district vary greatly in their susceptibility to metamorphism. Some units, such as the quartzite in the Havallah Formation, were bleached near contacts with igneous rocks but remain unchanged in composition and mineralogy. Other units, such as the Harmony and parts of the Havallah Formations, were recrystallized over wide areas.

\section{BATTLE FORMATION}

The rocks of the Battle Formation have been cut by the stock in Copper Canyon and extensively metamorphosed. The upper quartzose conglomerate was affected only slightly, whereas the lower calcareous conglomerate and middle calcareous shale were most susceptible to contact metamorphism.

In the lower conglomerate, chert and quartzite pebbles were little changed; calcareous pebbles, calcareous material, and iron oxides in the matrix formed an unstable mixture which was changed to lime silicates and formed a garnet-diopside-actinolite conglomerate. The calcareous sandstone and shale reacted similarly and formed garnet-diopside-actinolite quartzite and diopside-actinolite hornfels.

The middle calcareous shale was changed to garnetdiopside-actinolite hornfels and siliceous hornfels; some limy dolomitic beds were converted to tactite.

The siliceous conglomerate, sandstone, and shale were little changed during metamorphism except for recrystallization and bleaching. They became harder and now break across pebbles and grains when struck by a hammer. The cementing material, largely fine grained clastic quartz, was recrystallized. The quartzite and chert pebbles were little changed, but the conglomeratic texture was obscured to some extent by the recrystallization; however, the relict pebbles usually can be seen upon close study. The sandstone was generally recrystallized to quartzite, and the shale has been changed to siliceous hornfels or porcellanite. These rocks were locally leached white or to tints of green or gray; possibly the leaching took place largely during the later hydrothermal alteration.

To determine what chemical changes had occurred during metamorphism, samples of the Battle Formation were collected outside the zone of contact metamorphism
(1 and 2 in table 3) and also within the inner zone of metamorphism at the Copper Canyon mine (3-6 in table 3).

TABLE 3.-Analyses of unmetamorphosed and metamorphosea rooks of the Battle Formation, Antler Peak quadrangle

[Analyses by rapid methods. Analysts: P. L. D. Elmore, K. E. White, P. W Scott, F. S. Borris, and H. F. Phillips, U.S. Geol. Survey]

\begin{tabular}{|c|c|c|c|c|c|c|}
\hline $\begin{array}{l}\text { Lab No } \\
\text { Field No. }\end{array}$ & $\begin{array}{c}1 \\
53-544 \mathrm{C} \\
53-\mathrm{AP}- \\
15\end{array}$ & $\begin{array}{c}2 \\
53-544 \mathrm{C} \\
53-\mathrm{AP}- \\
18\end{array}$ & $\begin{array}{c}3 \\
144229 \\
86(122-138)\end{array}$ & $\begin{array}{c}4 \\
144230 \\
31(140-165)\end{array}$ & $\begin{array}{c}5: \\
144231 \\
84-(516-520)\end{array}$ & $\begin{array}{c}6 \\
144232 \\
76(16-21)\end{array}$ \\
\hline $\begin{array}{l}\mathrm{SiO}_{2} \\
\mathrm{Al}_{2} \mathrm{O}_{3} \\
\mathrm{Fe}_{2} \mathrm{O}_{3} \\
\mathrm{FeO} \\
\mathrm{MgO} \mathrm{O} \\
\mathrm{CaO} \\
\mathrm{Na}_{2} \mathrm{O} \\
\mathrm{K}_{2} \mathrm{O} \\
\mathrm{H}_{2} \mathrm{O} \\
\mathrm{H}_{2} \mathrm{O}- \\
\mathrm{TiO}_{2} \\
\mathrm{P}_{2} \mathrm{O}_{5} \\
\mathrm{MnO} \\
\mathrm{CO}_{2} \\
\mathrm{~S}_{2}\end{array}$ & $\begin{array}{c}62.0 \\
6.6 \\
4.1 \\
.81 \\
2.8 \\
9.6 \\
.14 \\
1.8 \\
2.0 \\
.11 \\
.80 \\
.18 \\
.13 \\
7.5 \\
-.-\end{array}$ & $\begin{array}{c}53.0 \\
7.8 \\
1.4 \\
1.7 \\
4.6 \\
13.2 \\
.20 \\
3.2 \\
2.3 \\
.10 \\
.46 \\
.23 \\
.08 \\
10.3 \\
\end{array}$ & $\begin{array}{c}55.4 \\
12.4 \\
14.6 \\
6.0 \\
.72 \\
.12 \\
2.3 \\
5.3 \\
.80 \\
.46 \\
.32 \\
.15 \\
2.0\end{array}$ & $\begin{array}{c}43.8 \\
13.2 \\
25.8 \\
6.8 \\
.68 \\
.04 \\
.22 \\
7.0 \\
1.0 \\
.49 \\
.40 \\
.72 \\
2.8\end{array}$ & $\begin{array}{c}81.4 \\
4.8 \\
6.3 \\
1.4 \\
.36 \\
.08 \\
2.0 \\
1.3 \\
.44 \\
.16 \\
.06 \\
.48 \\
2.0\end{array}$ & $\begin{array}{c}77.0 \\
5.6 \\
9.5 \\
2.2 \\
.37 \\
.04 \\
.64 \\
2.3 \\
.49 \\
.18 \\
.14 \\
.39 \\
2.6\end{array}$ \\
\hline Total & 99 & 99 & 101 & 103 & 101 & 101 \\
\hline
\end{tabular}

1. Calcareous shale from ridge 1 mile south of Galena, east of Nevada mine, NW $1 / 4$ sec. 22 , T. 31 N., R. $43 \mathrm{E}$.

2. Calcareous conglomerate from ridge three-fourths of a mile south
east of Nevada mine, SW14 sec. 15, T. $31 \mathrm{~N} ., \mathrm{R} .43 \mathrm{E}$.
3. Magnesian hornfels, diamond-drill hole 86 , Copper Canyon mine.

4. Garnet-diopside (magnesian) hornfels, diamond drill hole 31, Copper Canyon

5. Garnet-diopside conglomerate, diamond-drill hole 84, Copper Canyon mine.

It is not possible to closely correlate the samples, as they were collected $11 / 2$ miles apart, but sample 1 is representative of unmetamorphosed calcareous shale, and 3 and 4 are representative of metamorphosed shale.

Sample 2 represents unmetamorphosed lower conglomerate and 5 and 6 metamorphosed lower conglomerate. The unmetamorphosed rock is notably high in lime and carbon dioxide; the iron and magnesium oxide content are also fairly high, especially in the calcareous shale (sample 1). The most striking changes brought about by the metamorphism were increases in iron and sulfur which were accompanied by a noticeable decrease in lime and carbon dioxide. Magnesia, alumina, and water content were increased in the two hornfels samples $(3,4)$, which is possibly reflected in the chlorite now present. The amounts of other compounds were possibly changed somewhat, but the variations are not consistent and therefore cannot be evaluated.

PUMPERNICKEL FORMATION

The chert and shale of the Pumpernickel Formation are cut by the quartz monzonite intrusives at Copper Canyon (pl. 3). Three specimens of shaly chert were selected for microscopic study : at the contact, 1,200 feet from the contact, and 3,600 feet from the contact.

Chert 3,600 feet from the contact shows alternating layers of chert and shaly chert. The grain size of the chert ranges from 0.001 to $0.01 \mathrm{~mm}$, and the chert 
layers contain a few fragments of clastic quartz as much as $0.04 \mathrm{~mm}$ in diameter. The shaly chert layers contain more clastic fragments, possibly 20 percent in places, also in a cherty groundmass which is turbid because of included clay minerals. Argillite interbedded with the chert differs only in having a higher percentage of clay minerals and less cherty material in the ground mass.

Chert 1,200 feet from the contact has lost its vitreous luster and has become dull with a porcelaneous texture. The color may or may not be affected, but most dark beds show some bleaching. Under the microscope the chert has become coarser in grain size; some areas are cryptocrystalline, but much of the rock has become distinctly granular, and the grain size averages 0.01 to $0.03 \mathrm{~mm}$. The larger clastic grains show sutured borders and evidently have also grown during the crystallization of the groundmass. The shaly material in the rock has been changed to a fibrous mineral of high birefringence, probably hydromica or sericite, and locally there are plates of muscovite.

Chert collected a few feet from the contact is completely recrystallized. Bedding which was well defined a few hundred feet away is indistinct, and the shaly partings merge with the thicker granular chert beds. The rock is brown or reddish brown and looks like a fine-grained quartzite. Under the microscope the groundmass is crystalloblastic, and all the quartz grains show sutured borders. The grains are seriate, ranging in size from 0.01 to $0.2 \mathrm{~mm}$; and quartz veins, whose grains are as much as $0.5 \mathrm{~mm}$ in diameter, cut the rock. In addition to quartz, the groundmass contains considerable orthoclase in anhedral grains intergrown with the quartz. Biotite scattered throughout the groundmass in irregularly shaped plates and fibrous crystals is of secondary origin. It is similar to the mica of the quartz monzonite in pleochroism, with $\mathrm{X}=$ light yellow and $Z=$ reddish brown. The brownish color of the rock is probably due to the presence of the biotite and is the most characteristic outward sign of contact metamorphism. Tourmaline, associated with a dark reddishbrown isotropic mineral, occurs at one place in the section.

In the Farren tunnel, Copper Canyon mine, the contact of the quartz monzonite and the hornfels of the Pumpernickel Formation is exposed. Specimens of rock from the hornfels side of the contact are fine-grained rocks which in the hand specimen show feldspar crystals in a brown matrix. Under the microscope the rock is clearly not igneous, for although in places the rock is similar to border facies and dikes of the quartz monzonite, the texture is crystalloblastic. The mineral composition does bear a definite relation to that of the quartz monzonite, however, for large orthoclase and plagioclase crystals have been formed. These crystals do not have sharp borders like the phenocrysts of the quartz monzonite, but show irregular extensions into the groundmass. Aggregates show simultaneous extinction over a wide area and contain abundant inclusions of quartz and other minerals. The plagioclase crystals are about $\mathrm{An}_{40}$ in composition. Commonly they are veined by orthoclase and quartz. The quartz is in fine-grained aggregates in the groundmass and intergrown with orthoclase. Quartz in veinlets also cuts the rock. Biotite is present in small plates and in fibrous intergrowths with actinolite. The biotite is pleochroic with $\mathrm{X}=$ light yellow and $\mathrm{Z}=$ reddish brown. Actinolite, most abundant dark mineral, occurs as large crystals and fine fibers in the groundmass. It is moderately pleochroic, with $\mathrm{X}=$ light green, $\mathrm{Y}=$ pale brownish green, and $\mathrm{Z}=$ pale green.

The intrusive at Trenton Canyon cuts rocks belonging to the Pumpernickel Formation. As most of the rock types in this formation in contact with the granodiorite are finely granular argillite or chert, the products of the metamorphism are fine-grained hornfels and siliceous hornfels.

Specimens collected in the outer zone more than 1,000 feet away from the contact are fine grained, almost cryptocrystalline hornfels, showing only minute plates of clay minerals containing streaks of fine-grained biotite and disseminated sericite flakes.

Specimens of the hornfels in the intermediate zone within 1,000 feet of the contact are distinctly crystalline. Under the microscope they are crystalloblastic and show the presence of both muscovite and biotite in the groundmass. Streaks of fine-grained micas become coarser grained, and biotite forms aggregates several millimeters across. Orthoclase, cordierite(?), and apatite accompany the micas. Actinolite in fibrous crystals and rods begins to appear near the inner part of this zone. Impure siliceous rocks, such as chert and quartzite in this zone, are considerably recrystallized but still retain vestiges of their original texture; the groundmass cement generally contains some argillaceous material and is changed to quartz, orthoclase, and mica like the hornfels. Grain size of rocks composed of nearly pure silica, like chert and quartzite, is merely increased, and they acquire a granulitic texture.

\section{HAVALLAH FORMATION}

The Havallah Formation is cut by a major intrusive body in Trenton Canyon only. On the ridge south of Trenton Canyon the Trenton Canyon Member, which is mainly chert and shale, is directly in contact with the intrusive and has been converted to biotite hornfels. 
The overlying interbedded quartzite, sandy limestone, chert, and shale of the Mill Canyon Member have reacted in quite different ways to metamorphism. The quartzite is bleached over a wide area, locally extending south of Mill Canyon. Near the contact it is highly recrystallized and has a crystalloblastic texture. The sandy limestone layers have formed pods and layers of fibrous tremolite and likewise have a crystalloblastic texture. The chert and shale have been converted to biotite-cordierite siliceous hornfels and hornfels, similar to the hornfels of the Pumpernickel Formation that has been already described.

\section{SCOTT CANYON FORMATION}

The Scott Canyon Formation does not come into contact with any of the exposed larger intrusive bodies, but the small mass of quartz monzonite on 6573 hill south of Iron Canyon is probably a cupola of a large buried mass. In this area hornfels has been widely formed in the chert, shale, and volcanic material.

The chert and shale units of the Scott Canyon Formation are indurated, recrystallized, and locally changed to biotite hornfels near the Iron Canyon mine. The biotite hornfels, on the whole, contains more calcite than does the hornfels in the Pumpernickel Formation, but otherwise they are much alike.

The units containing volcanic material in the Scott Canyon Formation, however, react quite differently. Some of the material was originally tuffaceous, contained fragments of greenstone, and was highly susceptible to metamorphism. In the higher-grade inner zone, diopside,wollastonite, tremolite, and actinolite are the characteristic minerals. Barite, which was probably introduced later, is also a constituent of this zone. In the intermediate and outer zones, the minerals of the inner zone gradually disappear and give way to chlorite and sericite.

\section{HARMONY FORMATION}

The Harmony Formation is made up largely of feldspathic sandstone and shale. The sandstone contains both orthoclase and plagioclase grains and much biotite and muscovite. The cementing material, which may make up as much as 20 percent of the rock, is composed of carbonate, micaceous clay minerals, chlorite, shredded biotite and muscovite, and iron oxides. These minerals represent an unstable assemblage that was highly susceptible to contact metamorphism, and the metamorphic zone is wider in the Harmony Formation than in the other units (pl. 3). The shale units, being composed of almost the same material as the cement, were also unstable.

In the outer zone the main effect of metamorphism is induration due to the formation of quartz(?) and mica(?) in the cement. The new minerals are very fine grained and cannot be positively identified.

In the intermediate zone the shaly rocks of the Harmony Formation become hornfels; they acquire a brownish to dark-brown color and their characteristic thin bedding becomes obscure. On the surface the hornfels breaks down into angular fragments that form talus runs on steep slopes. The hornfels is commonly spotted owing to the formation of new minerals; in the outer part of the intermediate zone the hornfels is fine grained and contains minute specks of mica. The grain size increases inward with the development of a crystalloblastic texture and formation of biotite and muscovite flakes, orthoclase, epidote, zoisite, apatite, and sphene. In the feldspathic sandstones, the mineral assemblage is similar. The first new minerals, generally micas, formed in the cement, but as crystallization proceeded, the original quartz and feldspar also were recrystallized, and a crystalloblastic texture formed. The relict feldspar and quartz grains persisted during recrystallization, although the feldspars are generally replaced to a large extent by muscovite and sericite.

An analysis of a typical biotite hornfels from the Copper Canyon mine is given in table 4.

TABLE 4.-Analysis of biotite hornfels of the Harmony Formation, Copper Canyon mine

[Analyst: Faye H. Neuerburg, U.S. Geol. Survey]

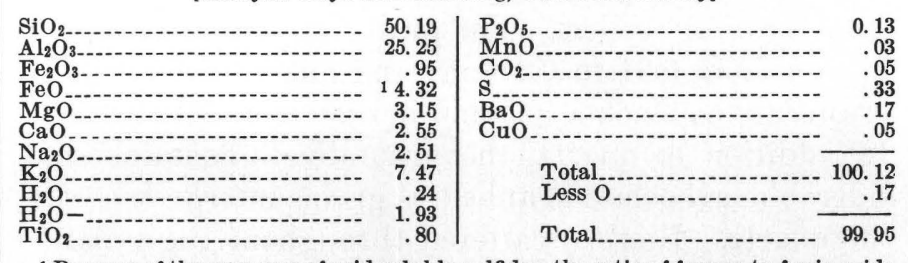

1 Because of the presence of acid soluble sulfides, the ratio of ferrous to ferric oxide is not reliable.

In a narrow inner zone, recrystallization has proceeded to the point where only a few quartz grains are recognizable as relicts of the original sandstone. The micas have been partly recrystallized also, forming orthoclase which makes up the groundmass of the rock. Some of the beds containing carbonate cement have formed sheaves and grains of diopside (fig. 2).

\section{VOLCANIC ROCKS OF TERTIARY AND EARLY QUATERNARY AGE}

Volcanic rocks are scattered throughout the quadrangle and cover about 4 square miles in area. These rocks include welded tuffs, quartz latite crystal tuffs of probable Tertiary age, and olivine basalt of late Tertiary or early Quaternary age.

Welded tuffs and associated pyroclastic rocks.Welded tuffs and associated pyroclastic rocks crop out near the Oyarbide Ranch and Buffalo Valley mine. 


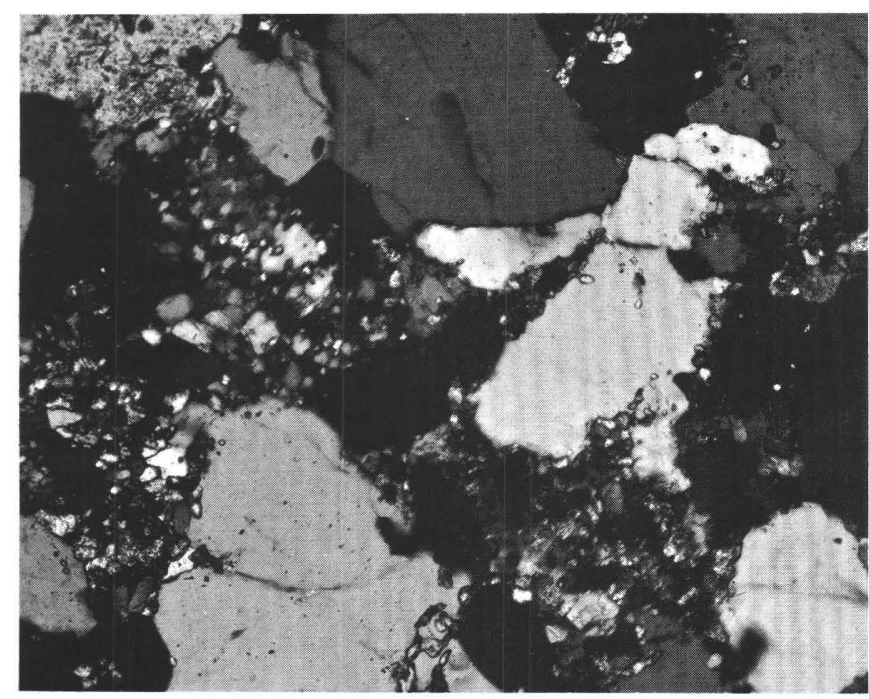

Figure 2.-Photomicrograph of metamorphosed sandstone, Harmony Formation. Shows clear quartz grains with interstitial diopside, orthoclase, and granoblastic quartz; turbid orthoclase (upper left). Cross-polarized light. $\times \mathbf{7 5}$.

These rocks consist mainly of vitric tuffs, in part welded, that reach a thickness of about 125 feet near the Oyarbide Ranch. The tuffs contain sparse sanidine crystals and pumice fragments and a few fragments of chert and quartzite.

Quartz latite welded crystal tuff.-Quartz latite welded crystal tuff at one time probably covered most of the range, but has been largely eroded except for small patches at Elephant Head and in Rocky Canyon. The quartz latite welded crystal tuff resembles lava, but was probably formed by some type of explosive eruption such as a nuée ardente. It differs markedly from the vitric tuff near the Oyarbide Ranch in that it is characterized by a high crystal content and is therefore described separately.

The quartz latite includes three gradational units: a lower tuff 10 to 20 feet thick; a middle vitrophyre 20 to 30 feet thick; and an upper aphanitic quartz latite about 120 feet thick. The lower tuff is composed of crystals and rock fragments, mostly pumice, in an ashy matrix. The pumice fragments still retain their original pumiceous structure, though they have been compressed a little. The middle vitrophyre contains about the same percentage of crystals and pumice fragments as the lower tuff, but they are tightly welded and compressed together so that, in places, the shard structure has been completely obliterated. The upper quartz latite resembles the vitrophyre, but the groundmass has been devitrified, giving the rock an aphanitic texture. Some layers are crowded with spherulites that are probably composed of sanidine(?) and tridymite(?).

The age of the quartz latite is not known, but similar volcanic rocks in the Cortez area have given a potas- sium-argon radiometric age of $33 \mathrm{~m} . \mathrm{y}$. (million years), according to H. A. Masursky (oral commun., 1964).

Basalt.-Erosion remnants of basalt flows occur in three areas on the periphery of the range. The largest remnants are in the Philadelphia-Box Canyon area and the others are at the mouth of Rocky Canyon and near Cottonwood Creek in the northwestern part of the quadrangle.

In the Philadelphia-Box Canyon area, the flows have a maximum thickness of about 150 feet; at least four flows can be recognized, the thickest being about 60 feet and the thinnest 25 feet. The basalt is composed of sparse olivine, augite, and plagioclase phenocrysts $\left(A n_{70-50}\right)$ in a groundmass of augite and olivine grains and plagioclase laths (about $\mathbf{A n}_{50}$ ).

The basalt flows in the Cottonwood Creek and Rocky Canyon areas are less conspicuously prophyritic but are similar in composition.

\section{GEOLOGIC STRUCTURE}

The structural features of north-central Nevada were formed during four major orogenic periods. Two of these took place during the Paleozoic, the Antler orogeny from Late Devonian to Early Pennsylvanian time, and the Sonoma orogeny in Late Permian time. The third was in the Mesozoic, probably in Jurassic and Cretaceous time. The fourth began in the Late Cretaceous or early Tertiary and culminated in the block faulting that outlined the present ranges.

The oldest structural features in the area are folds and thrust faults that are assigned to the Antler orogeny. Because the Battle Formation of early Middle Pennsylvanian (Atoka) age laps over the folds and faults, the orogeny is dated as pre-Atoka. Orogenic movements of Late Permian age, the Sonoma orogeny, are recorded in folds in the Havallah and Pumpernickel Formations. Subsequent Jurassic and Cretaceous orogenic movements resulted in folding and thrusting of Paleozoic and Mesozoic rocks in four successive pulses.

In order to illustrate the major structural features of Battle Mountain, a structural map has been prepared that shows the major facies of the Paleozoic rocks and the principal folds, thrust faults, and high-angle faults (pl. 2). The rocks are described in terms of structural blocks separated by major thrust faults as follows: the Valmy and Scott Canyon blocks of siliceous and volcanic assemblage rocks; the Dewitt block of transitional assemblage rocks; and the Golconda block of Havallah sequence rocks. Another, the Antler block, has been broadly warped along a northwestward-trending axis and has been cut by high-angle faults. 


\section{VALMY AND SCOTT CANYON BLOCKS}

The Valmy and Scott Canyon blocks, including Ordovician and Cambrian formations of the siliceous and volcanic assemblage, underlie the north-central and southeastern parts of the range. From regional relationships it is inferred that the sole thrust of the blocks - the Roberts Mountains thrust-passes beneath Battle Mountain at no great depth, and that they are allochthonous blocks whose structural features were formed partly during thrusting and partly after they reached their present position.

Valmy block.-The Valmy block is bounded on the west by the Golconda thrust and on the south and east by the Dewitt thrust. Folds in the Valmy block trend generally north-south and appear to plunge southward. Because of the difficulty of tracing units through complexly faulted areas, the system of folds was not worked out in detail.

Thrust faults in the Valmy block are probably subsidiary thrusts formed during movement on the Roberts Mountains thrust which underlies the range. Four were mapped during the course of fieldwork, and there are doubtless others that were not recognized. These thrusts separate members of the Valmy Formation in places, and their displacements appear to range from a few hundred feet to several miles.

One high-angle fault in the Valmy block that crosses Trout Creek about a mile east of the Oyarbide Ranch is of pre-Middle Pennsylvanian age as it does not displace the basal contact of the Battle Formation. Other high-angle faults, such as the Oyarbide, are of Tertiary or early Quaternary age, and they strike northeastward, northwestward, or northward.

Scott Canyon block.-The Scott Canyon block is bounded on the north by the Dewitt thrust and on the west by the Plumas-Trinity fault system. The block is cut by many north-trending high-angle faults that dip steeply west; displacements range from a few feet to more than 1,000 feet. Some of these faults contain dikes, and some contain mineral deposits. Many minor folds were noted in the Scott Canyon block, but no major ones were mapped.

\section{DEWITT BLOCK}

The Dewitt block, which underlies much of the east side of the range, is made up of the Harmony Formation which was moved into the Battle Mountain area on the Dewitt thrust. The Dewitt block has a broadly anticlinal structure whose axis strikes northwestward and is roughly coincident with the Antler anticline.

Many minor folds that trend northward were noted in the Dewitt block; most of them have gently dipping western flanks and steeply dipping or overturned eastern flanks, probably formed during eastward movement of the Dewitt thrust. One major fold, an overturned syncline, was mapped at the head of Cow Canyon about a mile east of Antler Peak. High-angle faults that cut the Dewitt block trend mostly northward and dip steeply westward.

\section{ANTLER BLOCK}

The Antler block includes the areas underlain by the Antler sequence in a belt extending northwestward diagonally across the range and in the northeastern part of the range. The Antler sequence overlapped the Scott Canyon, Valmy, and Dewitt blocks following the Antler orogeny and is therefore autochthonous with respect to the underlying blocks.

The Antler block has been warped into a broad northwestward-trending anticline whose axis passes about 2 miles northeast of Antler Peak; the central part is now largely eroded. The western limb dips $10^{\circ}$ to $40^{\circ} \mathrm{SW}$. and the eastern limb in Copper Basin dips $10^{\circ}$ to $30^{\circ} \mathrm{NE}$.

Many high-angle faults have been mapped in the Antler block; most of them strike northward and dip steeply westward.

\section{GOLCONDA BLOCK}

The Golconda block on the western side of Battle Mountain is made up of Havallah sequence rocks brought into the area on the Golconda thrust fault during the Sonoma orogeny. Its trace crosses the quadrangle diagonally from southeast to northwest, and it rests successively on the Antler, Dewitt, and Valmy blocks.

Folds in the Golconda block include north-striking anticlines and synclines. Some of them are broad open symmetrical folds, but most of them are asymmetrical and some are overturned. The major fold is a broad syncline, the Trenton Canyon syncline, which plunges gently southward; on the west it is flanked by the Timber Canyon anticline. A tight syncline, overturned to the east, was mapped on the ridge west of Copper Canyon. It is presumed that this syncline was formed during thrusting.

Faults in the Golconda block strike mostly northward and northeastward and dip steeply westward and northwestward. The northward-striking faults are in part steep reverse faults that probably formed during thrusting. The northeastward-striking faults have normal movement. A few normal faults that strike northwestward and displace the northeastward-striking faults were mapped. 


\section{HIGH-ANGLE FAULTS}

High-angle faults were formed in Battle Mountain during several periods, beginning in Mississippian time and extending into the Quaternary. Pre-Tertiary faults were recognized in the Valmy and Golconda blocks, but they are apparently less common than faults of Tertiary age.

The high-angle faults of Tertiary age have been divided into four groups: the oldest contains intrusive rocks; the second includes ore-bearing faults; the third, post-ore faults; and the fourth, range-front faults.

Faults containing intrusive rocks.-Some dikes in Battle Mountain follow high-angle faults that strike north, northwest, and west. These faults existed prior to intrusion of the bodies which have becn dated as late Eocene or early Oligocene, and the faults are therefore presumed to have formed in Eocene time. Northwesttrending faults contain ore bodies in the Copper Canyon mine.

Ore-bearing faults.-The second group of faults, the ore-bearing faults, cut the dikes and are therefore somewhat younger. For the most part they strike northward, dip westward, and have normal displacement. Some of them have been traced for several miles, and displacements of as much as 1,000 feet have been recorded. The Virgin, Plumas, Trinity, and Butte faults are typical of this group.

Postore faults.-The third group of Tertiary faults followed ore deposition, possibly in the Miocene or Pliocene. In part these faults may represent renewed movement along older faults, resulting in brecciation of vein fillings, but in part they represent new breaks. They can be recognized where they cut and displace the volcanic and pyroclastic rocks of Tertiary age. One of them bounds the basalt cap in sec. 35, T. 31 N., R. $43 \mathrm{E}$.

Range-front faults.-The fourth group of Tertiary faults includes the set that bounds the range and cuts rock units as young as the fan deposits. The fact that some of the scarps, such as the one on the west side of the range, are fresh suggests movement in the last few hundred years; but others, such as the one on the east side of the range, are subdued, a feature that suggests movement early in the present erosion cycle.

\section{ORE DEPOSITS}

The ore deposits in the Antler Peak quadrangle are mainly in the Copper Canyon, Galena, and Copper Basin areas, but other deposits also are scattered in the valleys of Willow, Elder, and Snow Creeks and on the western side of the range (pl. 3). The ore deposits occur mainly in altered zones that surround the intrusive rocks; in part, the ore bodies replace favorable units in the sedimentary sequence, and in part, they occur in shattered zones along faults. Secondary processes have aided in the enrichment of some ore deposits to shallow depths, but the bulk of the ore mined has come from the primary sulfide zone.

All the mines and prospects in the Antler Peak quadrangle are within the Battle Mountain district, which includes the Copper Canyon, Galena, Copper Basin, and Elder Creek areas. Properties in each area will be described under separate headings. In addition, isolated properties that are noteworthy because of unusual mineralogy or some production are described.

\section{MINERALOGY}

In the following section the minerals of the ore deposits are subdivided according to their major metal content, and are further subdivided according to their hypogene or supergene origin. The gangue minerals are then described separately in alphabetical order.

\section{ORE MINERALS \\ GOID}

Native gold $(\mathrm{Au})$ is one of the important economic constituents of the ore deposits and placers in the district. The gold occurs in minute grains in sulfide minerals, in narrow veinlets and crystals in quartz veins, and in placers. Most of the grains in sulfide minerals are of microscopic size. Pyrrhotite and chalcopyrite are the principal host minerals, but lacy pyrite is also gold-bearing in places. Assays of selected specimens of nearly pure minerals from the Copper Canyon mine were made available by $\mathrm{R}$. H. Raring. These specimens gave the following results:

\begin{tabular}{|c|c|c|}
\hline Mineral & $\begin{array}{c}\text { Gold } \\
\text { (ounces } \\
\text { per ton) }\end{array}$ & $\begin{array}{c}\text { Silver } \\
\text { (ounces } \\
\text { per ton) }\end{array}$ \\
\hline $\begin{array}{l}\text { Pyrrhotite (with some chalcopyrite) } \\
\text { Pyrite (lacy, } 500 \text { level) } \\
\text { Do }\end{array}$ & $\begin{array}{l}1.37 \\
1.50 \\
2.14\end{array}$ & $\begin{array}{l}7.3 \\
2.58 \\
1.7\end{array}$ \\
\hline
\end{tabular}

The gold content of associated galena and sphalerite crystals is generally very low and rarely exceeds 0.1 ounce per ton. Free gold in vein quartz is rare in the Copper Canyon mine area (fig. $11 B$ ); it has been seen in an amethyst quartz-pyrite vein cut in a diamond-drill hole and has been reported by R. H. Raring (oral commun., 1952) in a narrow quartz vein in the saddle between Copper and Box Canyons.

The most notable occurrence of native gold in the district was in the Nevada-Omaha mine where a vein of solid gold reported to be as much as 2 inches wide was mined from the surface down for about 30 feet. Several other veins in the area also contained native gold, but not in such spectacular amounts. 
Gold nuggets have been found in placers in most of the stream valleys on the north, east, and south sides of the range. The placer gold ranges in fineness from 770 to about 925 . Some nuggets are well rounded, indicating that they were transported long distances; others are rough and angular and have adhering quartz and rock fragments and evidently were found near the source areas.

Gold tellurides, possible petzite $\left(\mathrm{Ag}_{3} \mathrm{AuTe}_{2}\right)$, a member of the josëite $\left(\mathrm{Bi}_{3} \mathrm{TeS}\right)$-tetradymite $\left(\mathrm{Bi}_{2} \mathrm{Te}_{2} \mathrm{~S}\right)$ group, are constituents of veins in the Telluride area (Cutler, 1911, p. 845) at the head of Rocky Canyon.

\section{SILVER}

HYPOGENE MINERALS

Silver is widely distributed in the ore deposits of the area; it appears to be a minor constituent of many of the sulfides (see assays under gold), but is mainly in the galena, sphalerite, and tetrahedrite. Samples of galena were assayed for silver in the laboratory of the Copper Canyon Mining Co. and were found to contain as much as 222 ounces per ton. A summary of these assays follows:

\begin{tabular}{|c|c|c|c|c|}
\hline Mine & $\begin{array}{c}\text { Lead } \\
\text { (percent) }\end{array}$ & $\begin{array}{c}\text { Gold } \\
\text { (ounce } \\
\text { per ton) }\end{array}$ & $\begin{array}{c}\text { Silver } \\
\text { (ounces } \\
\text { per ton) }\end{array}$ & $\begin{array}{l}\text { Ratio } \\
\text { (ounces } \\
\text { Ag: per- } \\
\text { cent } \mathrm{Pb} \text { ) }\end{array}$ \\
\hline $\begin{array}{l}\text { D.D.H. 76, Copper Canyon mine } \\
\text { Lucky Strike mine } \\
\text { Driscol mine }\end{array}$ & $\begin{array}{l}55.4 \\
85.2 \\
75.7\end{array}$ & $\begin{array}{r}0.07 \\
.05 \\
.05\end{array}$ & $\begin{array}{l}143.3 \\
108.5 \\
222.0\end{array}$ & $\begin{array}{l}2.59 \\
1.27 \\
2.93\end{array}$ \\
\hline
\end{tabular}

Tetrahedrite.-Although tetrahedrite $\left((\mathrm{Cu}, \mathrm{Fe})_{12} \mathrm{Sb}_{4}\right.$ $\mathrm{S}_{13}$ ) is primarily a copper-antimony sulfosalt, it may contain considerable silver. For this reason, it is included with the silver minerals. Hill $(1915$, p. 74) reports that the rich silver ores in the White and Shiloh mine and in the Little Giant mine contain tetrahedrite. Charles Milton has recognized small particles of tetrahedrite in ores of the 500 level, Copper Canyon mine, and in ores of the Little Giant mine.

\section{SUPERGENE MINERALS}

Cerargyrite.-Masses of greenish-yellow cerargyrite $(\mathrm{AgCl})$ are found in the oxidized ore from the WilsonIndependence mine. The cerargyrite is associated with arsenic, bismuth, and iron oxides in the oxidized zone. Hill $(1915$, p. 74$)$ also reports that cerargyrite was a constituent of the silver ores mined at several properties during the early days of the camp.

Native silver.-Native silver (Ag) was reported from the White and Shiloh mine by Whitehill (1873, p. 41). As the workings were flooded in 1955 , and were inaccessible, the locality could not be visited.

Other minerals.-Other silver-bearing minerals that have been provisionally identified by Charles Milton are polybasite $\left((\mathrm{AgCu})_{16} \mathrm{Sb}_{2} \mathrm{~S}_{11}\right)$ and proustite $\left(\mathrm{Ag}_{3} \mathrm{AsS}_{3}\right)$ or pyrargyrite $\left(\mathrm{Ag}_{3} \mathrm{SbS}_{3}\right)$. The polybasite has been recognized in sulfide ores from the O'Leary (Buckingham) and Little Giant mines. The proustite or pyrargyrite was found in specimens from the O'Leary (Buckingham) mine.

The polybasite occurs in adit 5 at the Little Giant mine (fig. $13 B$ ), where it is associated with galena, sphalerite, tetrahedrite, pyrite, and chalcocite-covellite. This ore is composed mainly of primary sulfides, locally oxidized, and the polybasite may have formed late in the hydrothermal stage or early in the supergene stage. At the O'Leary (Buckingham) mine, sulfide ore from the 400 level contains polybasite(?) complexly intergrown with another sulfosalt, possibly pyrargyrite or proustite. These minerals replace unoxidized hypogene arsenopyrite, sphalerite, and galena; the 400 level is well below the oxidized zone, and the silver sulfosalts are believed to be hypogene, but they could be supergene.

\section{COPPER}

HYPOGENE MINERALS

Chalcopyrite.-Chalcopyrite $\left(\mathrm{CuFeS}_{2}\right)$ is the principal hypogene copper mineral and is a major constituent of the sulfide ores at the Copper Canyon mine where it occurs in narrow veins, pods, and irregularly shaped masses in brecciated chloritic conglomerate (figs. 10 A, $5 B$ ). Chalcopyrite is present also in veins in the Galena area where it is a minor constituent of the lead-zinc veins, and it occurs as scattered grains intergrown with sphalerite, galena, and pyrite. In Copper Basin, chalcopyrite has been found in hornfels and lime-silicate rock, and it was evidently the major source of the secondary minerals that now predominate in the deposits. Chalcopyrite, intergrown with pyrrhotite, is a constituent of massive sulfide ore at the Iron Canyon mine.

\section{SUPERGENE MINERALS}

Chalcocite.-Chalcocite $\left(\mathrm{Cu}_{2} \mathrm{~S}\right)$ is one of the principal ore minerals in the enriched ores at Copper Basin and in Copper Canyon. The chalcocite occurs in veinlets, pods, and irregular masses that coat and replace pyrite (fig. 12A), and to a lesser extent, pyrrhotite and arsenopyrite. At Copper Canyon mine the chalcocite zone extends from a short distance below the surface to the 300 level, and locally chalcocite is found on the 500 level. The chalcocite in Copper Basin mainly replaces disseminated pyrite, and the ore was less massive than in Copper Canyon. Consequently, early-day shipments from Copper Basin were small, but subsequent shipments have been significant during times of high copper prices.

Covellite.-Covellite (CuS) occurs locally in the enriched ores of the Battle Mountain district where it is 
usually associated with chalcocite. Thus far, it has been identified only in specimens studied under the miscrocope from the Little Giant (fig. 13B), Copper Canyon, and Sweet Marie mines.

Chrysocolla.-Chrysocolla $\left(\mathrm{CuSiO}_{3} \cdot 2 \mathrm{H}_{2} \mathrm{O}\right)$ is probably the most abundant copper mineral in the oxidized zones of the ore bodies in the district. It occurs as light bluish-green to deep apple-green crusts, botryoidal masses, and in veins (fig. 12B). The chrysocolla is associated with malachite and azurite, iron oxides, jarosite, and other secondary minerals. In ores of Copper Basin, the chrysocolla veins cut cuprite and chalcocite and are encrusted by later malachite and azurite.

Azurite.-Azurite $\left(\mathrm{Cu}_{3}(\mathrm{OH})_{2}\left(\mathrm{CO}_{3}\right)_{2}\right)$ is found in the oxidized ores of the Copper Canyon and Copper Basin areas, but it is not as abundant as malachite. One specimen of well-crystallized azurite needles up to a quarter of an inch long was collected from a prospect east of the Sweet Marie mine. Elsewhere the azurite is in finely crystalline to earthy masses associated with malachite and chrysocolla.

Malachite.-Malachite $\left(\mathrm{Cu}_{2}(\mathrm{OH})_{2}\left(\mathrm{CO}_{3}\right)\right)$ is one of the more abundant secondary copper minerals in the district. The malachite was mostly formed by the alteration of chalcocite and cuprite and occurs as pseudomorphs after these minerals. Malachite also occurs in veinlets and masses several hundreds of feet from copper ore bodies.

Chalcanthite.-Copper sulfates, such as chalcanthite $\left(\mathrm{CuSO}_{4} \cdot 5 \mathrm{H}_{2} \mathrm{O}\right)$, are found in the oxidized zones of most copper deposits in the district. The chalcanthite forms incrustations on the walls and timbers and stalagtites and stalagmites in the drifts and stopes. Locally the percentage of copper in sulfate form is high enough to warrant consideration of its recovery. Associated with chalcanthite are pisanite, the copper and iron sulfate, and melanterite, the iron sulfate (fig. 6). These minerals grade into one another and probably form a continuous series.

Tenorite (melaconite).-Tenorite $(\mathrm{CuO})$, a shiny, pitchlike mineral with a conchoidal fracture, is sparsely distributed throughout the oxidized zones of some copper deposits. The tenorite is commonly associated with chrysocolla, malachite and azurite, and other secondary copper minerals.

Cuprite.-Cuprite $\left(\mathrm{Cu}_{2} \mathrm{O}\right)$ is a constituent of the oxidized zones of copper deposits in Copper Basin and Copper Canyon. It commonly forms from the alteration of supergene chalcocite.

Native copper.-Native copper $(\mathrm{Cu})$ is a constituent of the oxidized ore at Copper Canyon and Copper Basin. It occurs in masses up to several pounds weight in the stopes in the footwall of the Virgin vein above the 260 level at Copper Canyon mine. Other properties where it is reported to occur include the Widow, Sweet Marie, and Copper Queen mines in Copper Basin, and in the Ridge mine in Elder Creek. The largest mass seen is a sheet 16 by 24 inches weighing about 30 pounds from the Copper Queen No. 4 mine (fig. $3 A$ ). This is a part of a still larger piece originally reported to weigh more than 50 pounds.
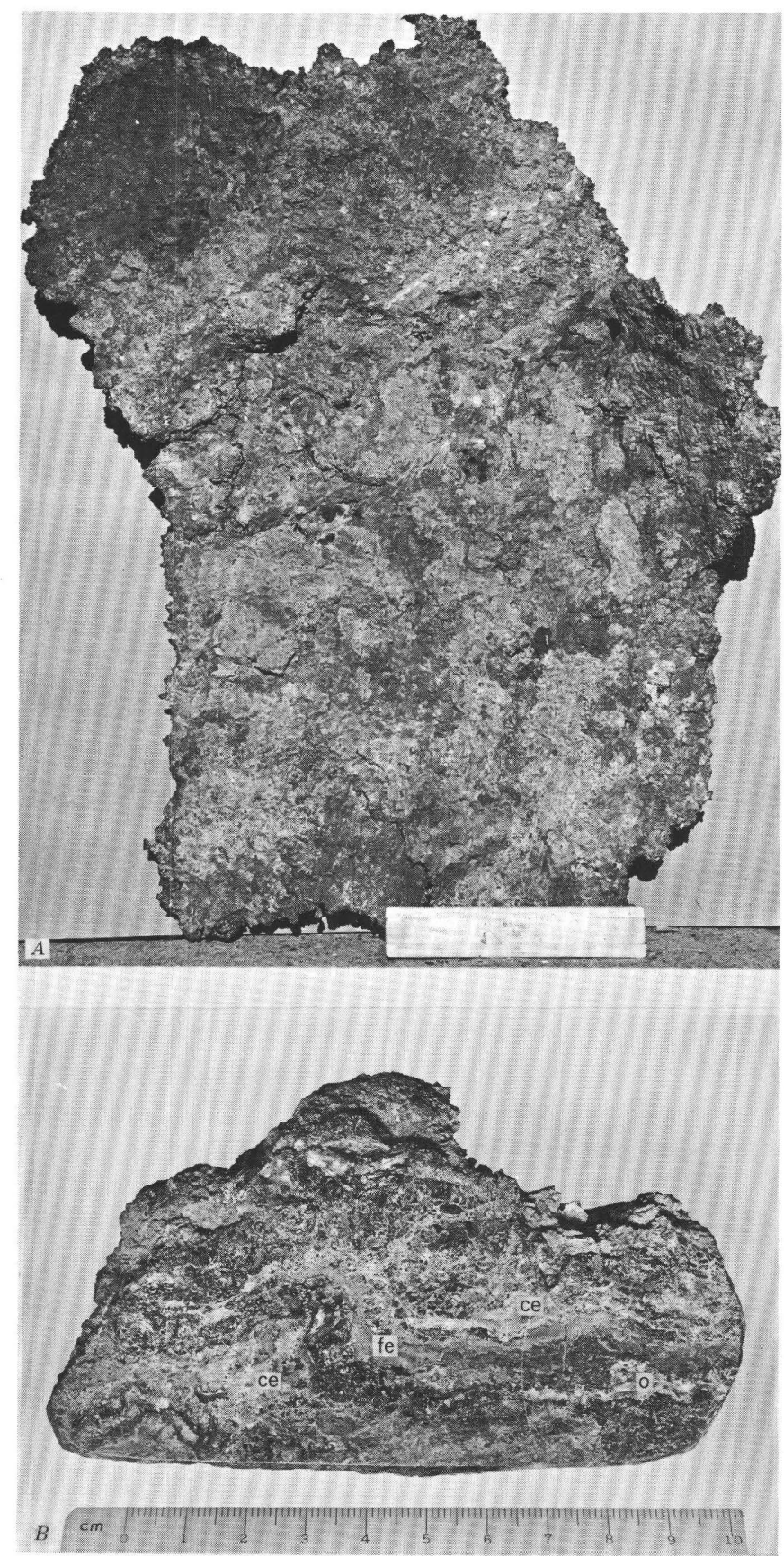

FIgure 3.- $A$, Plate of native copper, Copper Queen No. 4 mine. Scale is about $63 / 4$ inches long. $B$, Polished specimen of lead carbonate ore, Lemaire mine, Copper Basin. Cerussite (ce); iron oxides (fe); and lead oxide(?) (0). 
Turquoise.-Turquoise $\left(\mathrm{CuAl}_{6}(\mathrm{OH})_{8}\left(\mathrm{PO}_{4}\right)_{4} \cdot 4 \mathrm{H}_{2} \mathrm{O}\right)$, valuable as a gem stone, is a constituent in the oxidized zone in the Copper Basin area (figs. 13A, 14). Commonly the turquoise is not directly associated with other oxidized copper minerals, but it is found in the vicinity of copper mines. The phosphorus that the turquoise contains was probably derived from the host rock, the Harmony Formation, which contains about 0.10 percent $\mathrm{P}_{2} \mathrm{O}_{5}$. The turquoise occurs in narrow veinlets a fraction of an inch to 6 inches wide; in general, the narrower the vein, the higher quality the turquoise, that is, the deeper the color. Associated minerals are clay minerals (including richellite $\left(\mathrm{Ca}_{3} \mathrm{Fe}_{10}\right.$ $\left.\left.\left(\mathrm{PO}_{4}\right)_{8}(\mathrm{OH})_{12} \cdot n \mathrm{H}_{2} \mathrm{O}\right)\right)$, jarosite, and iron oxides.

\section{ANTIMONY}

\section{HYPOGENE MINERALS}

Stibnite.-Stibnite $\left(\mathrm{Sb}_{2} \mathrm{~S}_{3}\right)$ has been mined at the Antimony King mine in Little Cottonwood Creek and the Apex Antimony mine in Galena Canyon. Stibnite is also a minor constituent of the ore of the Trinity, Bentley, and Irish Rose mines. At the Antimony King mine, the stibnite is associated with a little pyrite. At the other mines, the stibnite accompanies pyrite, arsenopyrite, galena, sphalerite, and chalcopyrite. Small amounts of antimony are recorded in shipments of sulfide ores and concentrates from many other mines, chiefly in the Galena and Copper Canyon areas. The antimony is presumed to have been present originally as stibnite or as a sulfosalt.

\section{SUPERGENE MINERALS}

Near the surface, stibnite generally is oxidized to a mixture of antimony oxides. Specimens of the oxides were studied by $\mathrm{X}$-ray methods and determined by Charles Milton to belong to the stibiconite group $\left(\mathrm{Sb}_{3} \mathrm{O}_{6}(\mathrm{OH})\right.$ ?). Greenish-yellow crusts in oxidized ores at the Little Giant mine also were found to consist of a finely crystalline complex of minerals that belongs to the bindheimite-romeite-stibiconite groups.

\section{LEAD}

HYPOGENE MINERALS

Galena.-Galena ( $\mathrm{PbS})$ is widespread in the ore bodies of the Battle Mountain district. It is a major constituent in the lead-zinc ores and is a minor constituent in the copper ores. Commonly the galena is in finely granular masses intergrown with other sulfide minerals, but locally it is in nearly pure coarsely crystalline masses (fig. 11A). The most common associated sulfides in the lead-zinc ores at Copper Canyon are lacy pyrite, sphalerite, and chalcopyrite, which seem to be contemporaneous with the galena. In veins such as the
Driscol and Little Giant, galena appears to have been the principal sulfide mineral.

Most of the silver in the ores is in the galena. Analyses of selected specimens were given in the discussion of silver-bearing minerals. Study of polished specimens of the galena generally does not reveal silver-bearing minerals; the silver may be present in the form of sulfosalts that are too finely divided to be recognized at the magnifications used, in solid solution, or in the galena lattice.

\section{SUPERGENE MINERALS}

Anglesite.-Anglesite $\left(\mathrm{PbSO}_{4}\right)$ is present in galenabearing ores in the oxidized zone, commonly as a coating around galena relicts. The anglesite alters peripherally to cerussite.

Cerussite.-Cerussite $\left(\mathrm{PbCO}_{3}\right)$ is more widely distributed than anglesite and occurs as pods of finely crystalline aggregates (sand carbonate) and as euhedral crystals coating cavities and fractures (fig. $3 B$ ).

Other lead minerals. - Other secondary lead minerals, tentatively identified as plumbojarosite $\left(\mathrm{PbFe}_{6}(\mathrm{OH})_{12}\right.$ $\left.\left(\mathrm{SO}_{4}\right)_{4}\right)$ and mimetite $\left((\mathrm{PbCl}) \mathrm{Pb}_{4}\left(\mathrm{AsO}_{4}\right)_{3}\right)$, are present in the oxidized ores of the Nevada and Lucky Strike mines. As earthy iron oxides and jarosite are abundant in the oxidized ores, identification of secondary lead minerals is extremely difficult. Boulangerite $\left(\mathrm{Pb}_{5} \mathrm{Sb}_{4} \mathrm{~S}_{11}\right)$ has been recognized in ores of the Little Giant and Copper Canyon mines; its association with cerussite and iron oxides at the Little Giant mine suggests that it is supergene.

\section{ZINC \\ HYPOGENE MINERALS}

Sphaterite.-Sphalerite $(\mathrm{ZnS})$ is the predominant ore mineral in the Galena and Iron Canyon areas, at the Lucky Strike mine, and in the Hornfels ore body, 700 level, at the Copper Canyon mine (figs. 10 and $11 A$ ). Sphalerite was not a constituent of the oxidized and enriched silver ores mined during the early days.

In the Galena area, sphalerite is associated with galena and pyrite; in the Iron Canyon area, it is associated with pyrrhotite, pyrite, and minor galena. At the O'Leary (Buckingham) and Irish Rose mines, sphalerite is associated with arsenopyrite, pyrite, and a little galena (figs. 4 and $5 A$ ).

The sphalerite is dark brown to nearly black and is in the ferroan sphalerite (marmatite) range. Assays of the iron content of two samples follow:

\begin{tabular}{|c|c|c|}
\hline Sample & Locality & $\underset{\text { (percent) }}{\mathrm{Fe}}$ \\
\hline $\begin{array}{l}53 \mathrm{~A} 87 \\
69-395-\ldots\end{array}$ & \begin{tabular}{|l} 
Lucky Strike mine \\
Copper Canyon mine...
\end{tabular} & $\begin{array}{l}6.2 \\
9.4\end{array}$ \\
\hline
\end{tabular}




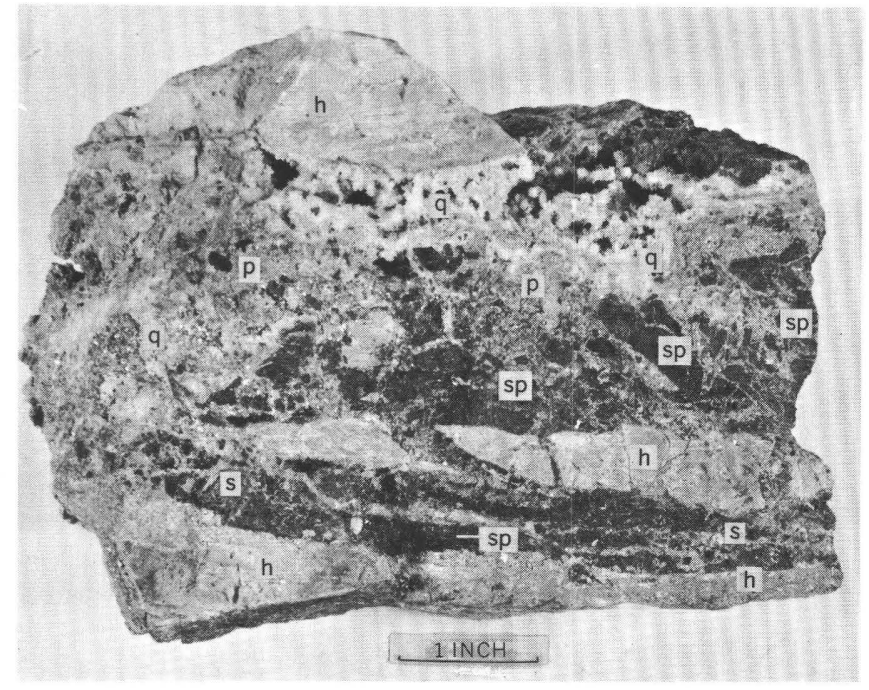

Figure 4.- Specimen of sulfide-quartz vein, Hardy vein, O'Leary mine. Drusy quartz $(q)$; sheared sphalerite $(s p)$; pyrite $(p)$; and pyritized hornfels (h).

\section{SUPERGENE MINERALS}

Smithsonite.-Smithsonite $\left(\mathrm{ZnCO}_{3}\right)$ is a constituent of oxidized ore bodies in the Galena and Iron Canyon areas and the Nevada and Lucky Strike mines. The smithsonite is mostly intimately intermixed with iron oxides and clay minerals, but locally it is in finely crystalline masses in pockets and coating fractures adjacent to sphalerite-bearing ore bodies.

Hydrozincite.-Hydrozincite $\left(\mathrm{Zn}_{5}(\mathrm{OH})_{6}\left(\mathrm{CO}_{3}\right)_{2}\right)$, in crystalline masses, accompanies smithsonite in the oxidized parts of zinc ore bodies.

Hemimorphite (calamine).-Hemimorphite $\left(\mathrm{Zn}_{4} \mathrm{Si}_{2^{-}}\right.$ $\left.\mathrm{O}_{7}(\mathrm{OH})_{2} \cdot \mathrm{H}_{2} \mathrm{O}\right)$ is also associated with smithsonite in oxidized parts of zinc-bearing ore bodies. The hemimorphite is partly in rosettes and sheaf-like crystal aggregates, but it also occurs intermixed with iron oxides and clay minerals.

Goslarite.-Goslarite $\left(\mathrm{ZnSO}_{4} \cdot 7 \mathrm{H}_{2} \mathrm{O}\right)$ is associated with iron and copper sulfates in the oxidized zone.

\section{CADMIUM}

Greenockite.-A little greenockite (CdS) was in yellow-green crusts coating cavities in ore bodies in the Lucky Strike mine.

\section{IRON}

\section{HYPOGENE MINERALS}

Pyrite-Pyrite $\left(\mathrm{FeS}_{2}\right)$ is an abundant constituent of the ore bodies in the Battle Mountain district, particularly so in the copper deposits. Two varieties of pyrite have been noted in the Copper Canyon ores: one is an early, massive pyrite (fig. $5 B$ ), and the other is a late, lacy pyrite (figs. 10 and $11 D$ ). The early py-
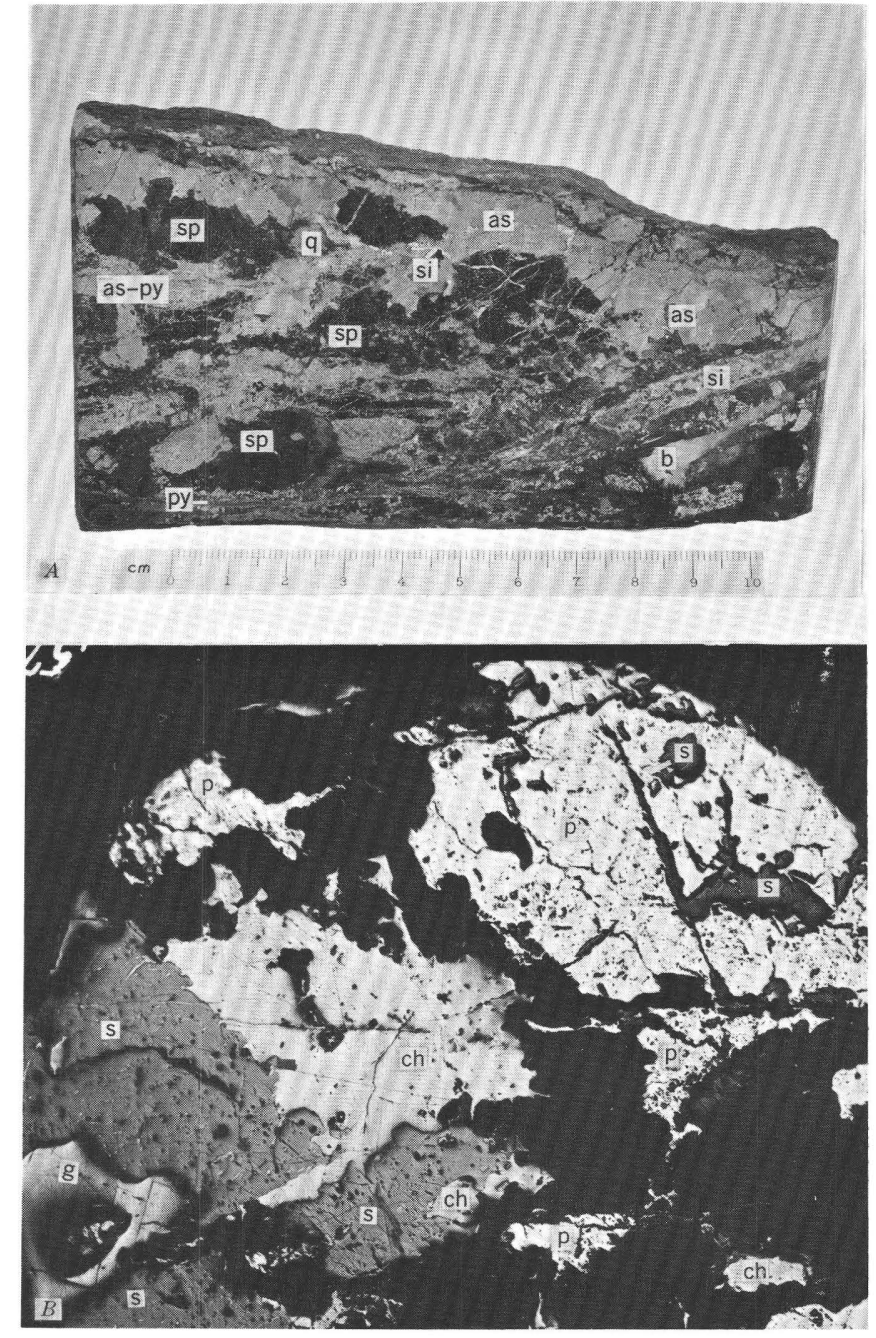

Figure 5.-A, Polished specimen of brecciated sulfide ore, Irish Rose mine. Consists mainly of arsenopyrite (as) and sphalerite (sp), minor amounts of pyrite (py), siderite(?) (si), barite (b), and quartz (q). $B$, Photomicrograph of complex sulfide ore, Copper Canyon mine. Early pyrite (p) containing blebs of sphalerite, chalcopyrite (ch), sphalerite (s), and galena (g). The black areas are cavities in the polished section. Plane light, $\times \mathbf{1 0}$.

rite is commonly coarsely crystalline and is light yellow. It occurs intergrown with arsenopyrite and pyrrhotite in veins, irregularly shaped masses, and pods in breccia. These minerals are associated with calc-silicate minerals, and they probably formed mainly during the contact metamorphic stage and early in the hydrothermal stage. Early pyrite also is widespread in alteration halos in the wallrocks, which extend hundreds of feet from the ore deposits. Although locally anhedral masses may be found, this pyrite is generally euhedral; typical crystal forms are cubes and pyritohedrons. The later pyrite is finely crystalline and is medium yellow. It occurs in veinlets and as porous masses within the ore zones where it is generally associated with chalcopyrite, sphalerite, and galena. The crystal forms are 
principally octahedrons with some pyritohedrons. Unlike the early pyrite, the later pyrite appears to be restricted to the ore deposits. The early pyrite is generally barren of gold and silver, whereas the late lacy pyrite has been found to be extremely rich locally in gold and silver.

Pyrrhotite.-Pyrrhotite $\left(\mathrm{Fe}_{1-\mathrm{x}} \mathrm{S}\right)$ is widespread in the ore deposits of the Battle Mountain district, especially in the Copper and Iron Canyon areas. Pyrrhotite occurs as small grains to large masses in the breccia ore at the Copper Canyon mine; it is closely associated with the early pyrite and arsenopyrite and locally is intergrown with chalcopyrite. Gold in pyrrhotite occurs as fine grains and as unidentified gold-silver telluride. In the Iron Canyon mine (fig. 10B), pyrrhotite is associated with pyrite and sphalerite in replacement bodies along bedding. Pyrrhotite occurs in the unoxidized gold-copper ore at the Copper King and Carissa mines in the Copper Basin area, where it is associated with altered lime silicates.

Specular hematite.-Specular hematite $\left(\mathrm{Fe}_{2} \mathrm{O}_{3}\right)$ was identified in a specimen collected from the Nevada mine. The hematite coats a fracture along the Virgin fault zone and is associated with quartz and epidote.

Magnetite.-Magnetite $\left(\mathrm{Fe}_{3} \mathrm{O}_{4}\right)$ is a common constituent of the contact metamorphic zones at the Copper Canyon and Copper Basin areas. It is associated with the lime and magnesia silicate minerals and with the early sulfide minerals where it occurs as finely crystalline grains disseminated throughout the contact metamorphic zone.

Marcasite.-Marcasite $\left(\mathrm{FeS}_{2}\right)$ is locally a constituent of pyritic ore from the 500 level, Copper Canyon mine, where it fills cavities in massive pyrite (fig. 11D).

\section{SUPERGENE MINERALS}

Hematite.-Hematite $\left(\mathrm{Fe}_{2} \mathrm{O}_{3}\right)$ is widespread in the oxidized parts of the veins in the district. The hematite was derived mainly from the original iron sulfides or carbonates in the ore. It is generally in irregularly shaped, red earthy masses associated with clay minerals and other iron oxides.

Goethite.-A yellow-brown coating on barite from the White and Shiloh mine was identified as goethite $\left(\mathrm{HFeO}_{2}\right)$. Goethite is probably widespread in the oxidized ores of the district.

Limonite.-Limonite (hydrous iron oxides), an abundant constituent of the oxidized ore bodies of the district, is associated with hematite, goethite, and jarosite. The limonite occurs in earthy porous masses where it is relict after sulfides or siderite, or in hard dense masses and crusts where it has been transported and rede- posited. The earthy limonite locally contains gold and silver and has been shipped from the Plumas, Butte, and Iron Canyon mines. At Iron Canyon, a spongy and cindery limonite body derived from the oxidation of pyrite and pyrrhotite was as much as 8 feet thick.

Jarosite. -Jarosite $\left(\left(\mathrm{K} \mathrm{Fe}_{3}\right)\left(\mathrm{SO}_{4}\right)_{2}(\mathrm{OH})_{6}\right)$ is another common oxidation product of iron sulfides and occurs with iron oxides in the oxidized parts of many ore deposits in the area. The jarosite is yellow to brown and forms crusts on fracture walls and finegrained masses in veins. It is especially abundant in the Copper Basin area where it is secondary after pyrite. The jarosite occurs in pockets in the wallrock and in the ore deposits. In the Blue Gem Turquoise mine, jarosite is intimately associated with turquoise and clay minerals (fig. 14).

Melanterite.-Efflorescences of melanterite $\left(\mathrm{FeSO}_{4}\right.$ $\left.\cdot 7 \mathrm{H}_{2} \mathrm{O}\right)$ and chalcanthite $\left(\mathrm{CuSO}_{4} \cdot 5 \mathrm{H}_{2} \mathrm{O}\right)$ crust the walls of workings and occur as stalagmites and stalactites in the stopes throughout the district (fig. 6). Where iron and copper were both available in the mine waters, mixtures of these minerals or minerals of the melanterite-pisanite series probably formed. At the Copper Canyon mine and in some mines in Copper Basin, a significant part of the copper in the oxidized zone may be present in mixtures of iron and copper sulfates.

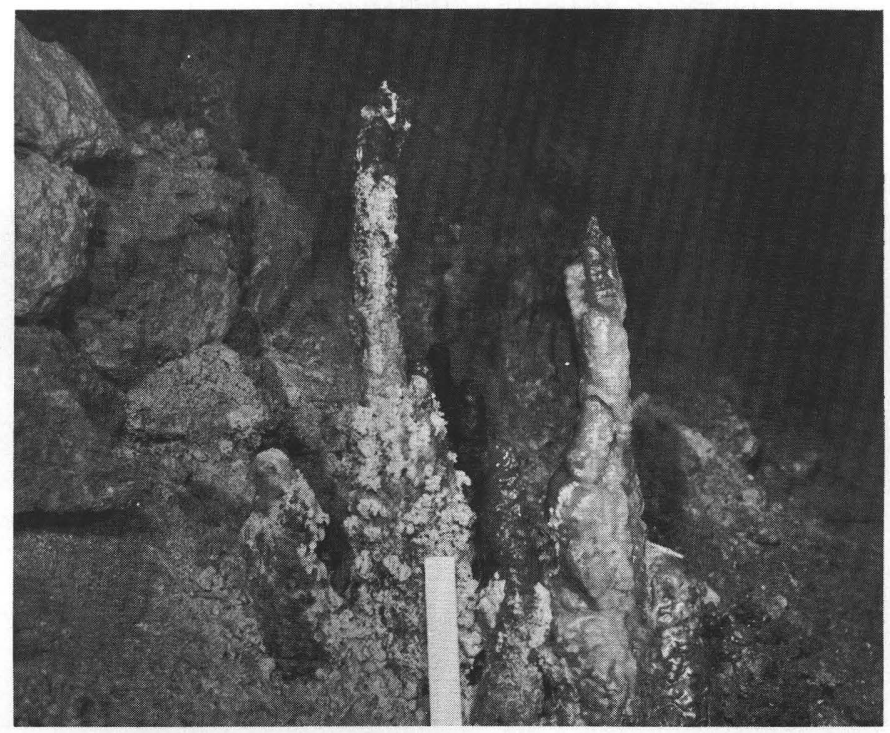

Figure 6.-Stalagmites of melanterite, main level, Plumas mine. The scale is about $63 / 4$ inches long.

\section{MANGANESE}

HYPOGENE MINERALS

Braunite.-Braunite $\left((\mathrm{MnSi})_{2} \mathrm{O}_{3}\right)$ is the only primary manganese mineral recognized in the ores of the Black Rock mine. It occurs in finely crystalline masses and pods cut by veinlets of manganese oxides. 
SUPERGENE MINERALS

Manganese oxides.-The manganese minerals that can be identified in the ores of the Black Rock mine include pyrolusite $\left(\mathrm{MnO}_{2}\right)$, psilomelane $\left(\mathrm{BaMnMn}_{8} \mathrm{O}_{16}\right.$ $\left.(\mathrm{OH})_{4}\right)$, and wad. Psilomelane in dense masses and earthy wad are the predominant minerals. Pyrolusite is in finely crystalline aggregates and veins and forms only a small part of the ore. These minerals are in pockets and veins in chert and shale of the Havallah Formation.

In addition, small amounts of earthy manganese oxides occur in the oxidized parts of ore bodies in the Copper Basin, Copper Canyon, and Galena areas. The source of these oxides is not definitely known, but it is thought to have been concentrated from the small amounts of manganese present in the ores and wallrocks.

\section{ARSENIC}

HYPOGENE MINERALS

Arsenopyrite.-Arsenopyrite (FeAsS) is widespread in the ore deposits of the Copper Canyon and Iron Canyon areas and in the southwestern part of Copper Basin. The arsenopyrite is one of the early sulfides and generally occurs as euhedral crystals. At the Copper Canyon mine, the crystals are as much as half an inch long and characteristically show wedge-shaped forms having short prism faces and domes. Arsenopyrite at the Iron Canyon mine is commonly anhedral and is intergrown with pyrrhotite and sphalerite. At the Irish Rose mine in the southwestern part of Copper Basin, arsenopyrite is the principal sulfide (fig. $5 \mathrm{~A}$ ). The arsenopyrite, which is accompanied by sphalerite, galena, pyrite, and a little chalcopyrite, is mostly anhedral and massive, although some euhedral wedgeshaped crystals were noted. Euhedral arsenopyrite crystals were also noted at the Copper Canyon and Eldorado mines and adjacent prospects.

SUPERGENE MINERALS

Scorodite.-Scorodite $\left(\mathrm{FeAsO}_{4} \cdot 2 \mathrm{H}_{2} \mathrm{O}\right)$ is the principal oxidation product of arsenopyrite and forms a large part of the ore body of the Wilson-Independence mine. The scorodite is in dark greenish-brown pods and in pale-green porous aggregates cut by quartz veins. Pockets of iron oxides are locally associated with the scorodite, presumably derived from iron in arsenopyrite. The scorodite-quartz aggregate contains gold and silver, and after screening to remove large quartz fragments, it was shipped directly. Shipments of the screened material contained as much as 30 percent, arsenic and are therefore nearly half scorodite. Scorodite is also a constituent of the oxidized ores at Copper Canyon, Iron Canyon, and at the Irish Rose mine.
Realgar and orpiment.-Small pods of realgar (AsS) and orpiment $\left(\mathrm{As}_{2} \mathrm{~S}_{3}\right)$ were noted in partially oxidized ore in the 300 level at the Copper Canyon mine. These minerals are believed to be secondary after arsenopyrite.

\section{MINOR MINERALS}

Bismuth.-Bismuth has been reported by F. C. Schrader (1933, p. 120) from ores of the Elko-Lander mine. Charles Milton also found bismuth in a specimen containing cerargyrite from the Wilson-Independence mine. Neither the source of the bismuth nor its mode of occurrence in these two properties is known.

Molybdenum.-Molybdenite $\left(\mathrm{MoS}_{2}\right)$ occurs in narrow veins and as fracture coatings in the 500-level workings of the Copper Canyon mine. The distribution of the molybdenite is erratic and no attempt has been made to recover it in mining. At the Miss Nevada mine in the western part of Copper Basin molybdenite occurs with pyrite in a fault zone. As the workings are partly caved, the extent of the occurrence could not be determined.

Tungsten.-Scheelite $\left(\mathrm{CaWO}_{4}\right)$ occurrences are known in the Copper King and Carissa mines, in the Copper Basin area, and in the Copper Canyon mine. The scheelite is associated with calc-silicates of the contact-metamorphic zone and apparently was introduced during the period of metamorphism. Attempts to work the scheelite at the Cooper King mine have thus far not been successful, but the scheelite at the Copper Canyon mine may be of commercial value. The principal showing is in a drill hole below the 700 level where nearly 50 feet of material averaging about 0.5 percent $\mathrm{WO}_{3}$ was cut.

\section{GANGUE MINERALS} SILICATES

Actinolite.-Actinolite $\left(\mathrm{Ca}_{2}(\mathrm{Mg}, \mathrm{Fe})_{5} \mathrm{Si}_{8} \mathrm{O}_{22}(\mathrm{OH})_{2}\right)$ is an important constituent of the calc-silicate rocks in the Battle Mountain district. It occurs as radiating masses and felted aggregates in limy beds in the Battle Formation and Antler Peak Limestone and is associated with tremolite $\left(\mathrm{Ca}_{2} \mathrm{Mg}_{5} \mathrm{Si}_{8} \mathrm{O}_{22}(\mathrm{OH})_{2}\right)$.

Albite.-Albite $\left(\mathrm{NaAlSi}_{3} \mathrm{O}_{8}\right)$ is one of the rarer constituents of the contact-metamorphic aureoles. It occurs in scattered grains associated with orthoclase and quartz. Albite is present also in greenstone of the Scott Canyon and Valmy Formations where it occurs in veinlets and also replaces the earlier, more calcic feldspars.

Chlorite.-Chlorite (hydrous silicate of iron, magnesium, and aluminum) is one of the widespread silicate minerals in the ores at the Copper Canyon mine (figs. $9,10 \mathrm{~A}$ ) and is present also in small amounts in altered rocks in the mines in Copper Basin. 
The chlorite at the Copper Canyon mine is a secondary product formed mainly during the hydrothermal alteration of the calc-silicate minerals originally part of the contact aureole. The chlorite is pseudomorphic after diopside, actinolite, and biotite and also occurs in narrow veinlets bordering hornfels fragments and quartz veins (fig. $11 C$ ). In hand specimens the chloritized rock is medium to dark green and is distinctly softer than the unaltered rock. In parts of the mine where post-alteration shearing has taken place, the chlorite is commonly smeared out on shear planes. The chlorite shows considerable variation in optical properties and is probably highly variable in composition.

Clay minerals.-A suite of clay minerals and related minerals were formed during hypogene and supergene alteration in the Copper Canyon district. Among the first to form during the hypogene stage were hydromica and chlorite; later supergene clay minerals include montmorillonite $\left((\mathrm{Al}, \mathrm{Mg})_{8}\left(\mathrm{Si}_{4} \mathrm{O}_{10}\right)_{3}(\mathrm{OH})_{10} \cdot 12 \mathrm{H}_{2} \mathrm{O}\right)$, halloysite $\left(\left(\mathrm{OH}_{5} \mathrm{Si}_{4} \mathrm{Al}_{4} \mathrm{O}_{10}\right)\right.$, and kaolinite $\left((\mathrm{OH})_{8} \mathrm{Si}_{4}\right.$ $\mathrm{Al}_{4} \mathrm{O}_{10}$ ).

Epidote.-Epidote $\left(\mathrm{Ca}_{2}(\mathrm{Al}, \mathrm{Fe})_{2}(\mathrm{OH}) \mathrm{Si}_{3} \mathrm{AlO}_{12}\right)$ and associated minerals of the epidote and zoisite group are widespread minor constituents of the rocks of the contact metamorphic aureoles in Copper Canyon and Copper Basin. Epidote also occurs in a vein along the Virgin fault zone at the Nevada mine. The epidote is in small crystals intergrown with specularite and quartz.

Muscovite and sericite.-Plates of muscovite $\left(\mathrm{H}_{2} \mathrm{KAl}_{3}\left(\mathrm{SiO}_{4}\right)_{3}\right)$ and aggregates of fine-grained sericite are to be found in the rocks of the contact aureole in the Copper Canyon mine. These minerals are associated with biotite $\left(\mathrm{H}_{2} \mathrm{~K}(\mathrm{Mg}, \mathrm{Fe})_{3}(\mathrm{Al}, \mathrm{Fe})\left(\mathrm{SiO}_{4}\right)_{3}\right)$ and appear to have been among the latest minerals formed during contact metamorphism. A sericitic mineral was also noted associated with goethite in crusts on barite crystals at the White and Shiloh mine.

Orthoclase.-One of the most abundant constituents of the contact aureoles in the district is orthoclase $\left(\mathrm{KAlSi}_{3} \mathrm{O}_{8}\right)$, which occurs in fine intergrowths and veinlets containing quartz (fig. 8).

Sphene.-Minute grains and veinlets of sphene $\left(\mathrm{CaTiOSiO}_{4}\right)$ are scattered throughout the calc-silicate rock. In places the sphene is bordered with a white alteration product believed to be leucoxene.

Barite.-Barite $\left(\mathrm{BaSO}_{4}\right)$ is a widespread gangue mineral in the Battle Mountain district. It is associated with sphalerite, galena, and pyrite at the White and Shiloh mine. At the Iron Canyon mine, a vein of massive, white, finely crystalline barite as much as 8 feet wide is exposed near the Planet adit. Barite is also a constituent of the contact metamorphic zone at the portal of the Farren tunnel, Copper Canyon mine.
Massive crystalline barite also occurs in many fault zones that cut the Havallah Formation in the southwestern part of the quadrangle in the Timber Canyon area. The veins are podlike and range from a few inches to 10 feet wide. Some of them contain pockets of iron oxides, probably derived from pyrite.

A prospect on the west side of Rocky Canyon in the NW1/4 sec. 7, T. 31 N., R. 43 E., shows a north-striking barite-chalcopyrite vein in the Antler Peak Limestone.

Calcite.-Calcite $\left(\mathrm{CaCO}_{3}\right)$ is a constituent of many veins in the area and is especially abundant in the leadzinc veins of the Galena area and also in the Lucky Strike and Nevada mines. The calcite occurs as early crystals intergrown with the sulfides and also as later veins that cut the sulfides. The early calcite is generally white or gray and is fine to medium grained. At Copper Canyon it occurs with arsenopyrite and sphalerite and is probably later than these. Minute needles of calcite having scalenohedral habit were noted in cavities in specimens of lead-zinc ore from the 700 level of the Copper Canyon mine. This calcite belongs to the late stage and is probably even later than siderite formation. At the Midland and Hardy mine euhedral rhombs of calcite and octahedrons of sphalerite coat comb quartz.

Quartz.-Quartz $\left(\mathrm{SiO}_{2}\right)$ is the most common gangue mineral in the ore deposits. Individual veins are not large, seldom exceeding a foot in width, but stringer zones and stockworks locally form conspicuous outcrops. The quartz is mostly in veins or crusts of comb quartz which are made up of numerous subparallel crystals. The quartz is glass clear in places, but generally it contains inclusions of clay, chlorite, and bubbles of gas or liquid.

At Copper Canyon, most of the quartz was formed following the contact-metamorphic stage after faulting and was later brecciated. The comb quartz crystals up to an inch long fill cavities in chloritized breccia. The quartz is contemporaneous with the early sulfides, pyrite, arsenopyrite, and pyrrhotite. Sphalerite, chalcopyrite, and galena fill cavities between the quartz crystals.

Fine-grained quartz masses in silicified zones along faults appear to have been formed by silicification of broken and sheared rock in the fault zone. Commonly these masses are lenticular and are as much as 50 feet wide along the Monitor fault. Coarse crystalline quartz veins cut across the finer quartz and also cut the adjacent wallrock.

Small masses of red and brown jasperoid replace Antler Peak Limestone in the northern and eastern parts of Copper Basin. The jasperoid was formed along fault zones. Locally it contains pockets of iron oxides and oxidized lead minerals, but no significant production has been reported from any prospects in it. 
Siderite.-Siderite $\left(\mathrm{FeCO}_{3}\right)$ was a late gangue mineral at the Copper Canyon mine (fig. 9). The siderite is in small cream or greenish-brown crystals that generally show a curved rhombohedral habit. The crystals coat quartz and all the early sulfides and evidently formed near the end of the vein-forming period. Near the surface the siderite is oxidized and is coated with goethite and limonite.

\section{GENERAL CHARACTER AND CLASSIFICATION OF THE ORE DEPOSITS}

The ore deposits of the district are so closely related spatially to the centers of intrusive activity that there seems to be no question as to their genetic relationship to the intrusives. The late state of igneous activity was continuous with the early stage of formation of the contact deposits. This is most strikingly demonstrated by the persistence of late-stage potash-bearing minerals in the igneous rocks and widespread potash metasomatism in the metamorphic aureoles. Biotite and orthoclase are the two principal indicator minerals of this metasomatism.

After the early contact metamorphic stage, probably with little lapse in time, the metamorphosed rocks were fractured. This fracturing permitted solutions to rise on the faults and spread through the fractured rocks. The earlier minerals were altered and the main period of sulfide deposition - the hydrothermal period - began and continued over a long time with gradually falling temperatures.

After the hydrothermal period, weathering of the upper parts of the primary deposits caused the solution of soluble constituents and the redeposition of some of them at the water table as supergene deposits. These supergene deposits subsequently have been partially oxidized.

Because of this complex history, the ore deposits of the Battle Mountain district exhibit great variation with respect to both their metal content and form, and no simple system can be used to classify them. Under these circumstances, it seems best to use a system of classification that includes both metal content and form, with major divisions based on the metal content and with subdivisions based on the form. The scheme of classification that will be used in this report is as follows :

1. Copper-gold deposits

a. Replacement deposits

b. Supergene copper deposits

c. Copper-gold veins

2. Gold-silver deposits

3. Lead-zinc-silver deposits

a. Replacement deposits

b. Veins

4. Antimony deposits

\section{COPPER-GOLD DEPOSITS}

REPLACEMENT DEPOSITS

The most productive deposits in the Battle Mountain district are replacement copper-gold deposits in the Copper Canyon and Copper Basin areas. At Copper Canyon the ore is mainly sulfide ore in the lower conglomerate of the Battle Formation and, to a lesser extent, in the hornfels of the middle unit of the formation. At Copper Basin the ore consists of oxidized and secondary copper minerals in sandstone and shale of the Harmony Formation, in dikes and sills of quartz monzonite porphyry, and in conglomerate of the Battle Formation. The general sequence of events was probably similar at Copper Canyon and Copper Basin, but as the stages are better preserved at Copper Canyon, the following description is based largely on the ore bodies there.

Metallization at Copper Canyon was a long complex process which can be divided into three principal stages (fig. 7). The first occurred during the contact-metamorphic stage which was associated with the intrusion of the quartz monzonite. Calcareous rocks near the intrusive were metamorphosed to calc-silicate hornfels and tactite and siliceous rocks to quartzite, biotite hornfels, and a rock resembling quartzite. Potash metasomatism was a significant process during this stage; pyrite, magnetite, and scheelite were introduced also at this time. The pyritization was widespread and pervasive and extended over much of the eastern half of the quadrangle (pl. 3).

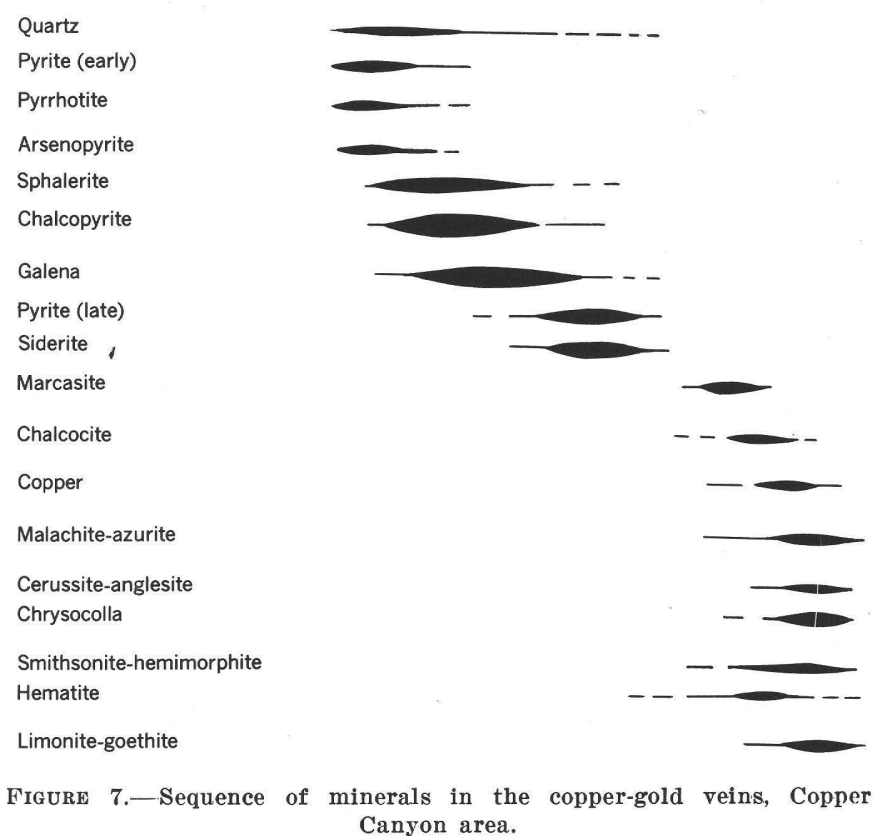

Quartz

Arsenopyrite

Sphalerite

Galena

Pyrite (late)

Siderite

Copper

Malachite-azurite

Chrysocolla

Hematite

Canyon area. 
The contact-metamorphic stage was followed closely by the hydrothermal stage during which the earlier formed tactite and hornfels were altered and most of the sulfide minerals were deposited. During alteration, the iron- and magnesia-bearing silicates were changed to hydromica and clay minerals in equilibrium with the hydrothermal solutions. The first ore minerals formed during the hydrothermal stage include molybdenite, arsenopyrite, pyrrhotite, cubic pyrite, sphalerite, chalcopyrite, galena, lacy pyrite, and gold. The ore minerals formed during the second part include marcasite, tetrahedrite, and boulangerite.

Following the hydrothermal stage, possibly after a long time-gap, the upper parts of the ore bodies were oxidized. Acid solutions derived from the oxidation of sulfides carried copper and silver downwards and deposited them below the water table where they formed an enriched zone. Subsequently, erosion has removed the upper parts of the ore bodies so that the enriched ore bodies are at or near the surface.

\section{CONTACT METAMORPHIC STAGE}

Following the intrusion of the quartz monzonite at Copper Canyon and Copper Basin, the calcareous wallrocks were metamorphosed to lime and magnesium hornfels, and the siliceous rocks were metamorphosed to quartzite or rocks resembling quartzite. These metamorphic changes have already been briefly described in the section on metamorphism of the sedimentary rocks, but pertinent details concerned primarily with the ore bodies were omitted there and will be discussed here.

The calcareous wallrocks in contact with intrusive quartz monzonite include the lower and middle units of the Battle Formation at Copper Canyon, and the upper part of the Harmony Formation, the lower part of the Battle Formation, and the Antler Peak Limestone at Copper Basin. At Copper Canyon the calcareous rocks were metamorphosed to garnet-diopside-actinolite tactite and hornfels. Near the intrusive contacts, potash metasomatism was important; during this process orthoclase, sericite, and biotite replaced the wallrocks.

The orthoclase, which commonly accompanies quartz in veinlets (fig. 8) or is disseminated throughout the rock, was formed farther from the intrusive than either sericite or biotite. The distribution of orthoclase is by no means uniform, but it is present in most parts of the contact metamorphic zone. Biotite and sericite were formed also during contact metamorphism. The biotite is light brown, moderately pleochroic, and occurs in fibrous sheaves and small, generally equidimensional plates. The pleochroism is $\mathrm{X}=$ very light yellow, $\mathrm{Y}=$ light brown, and $\mathrm{Z}=$ light greenish brown. The $\mathrm{Y}$
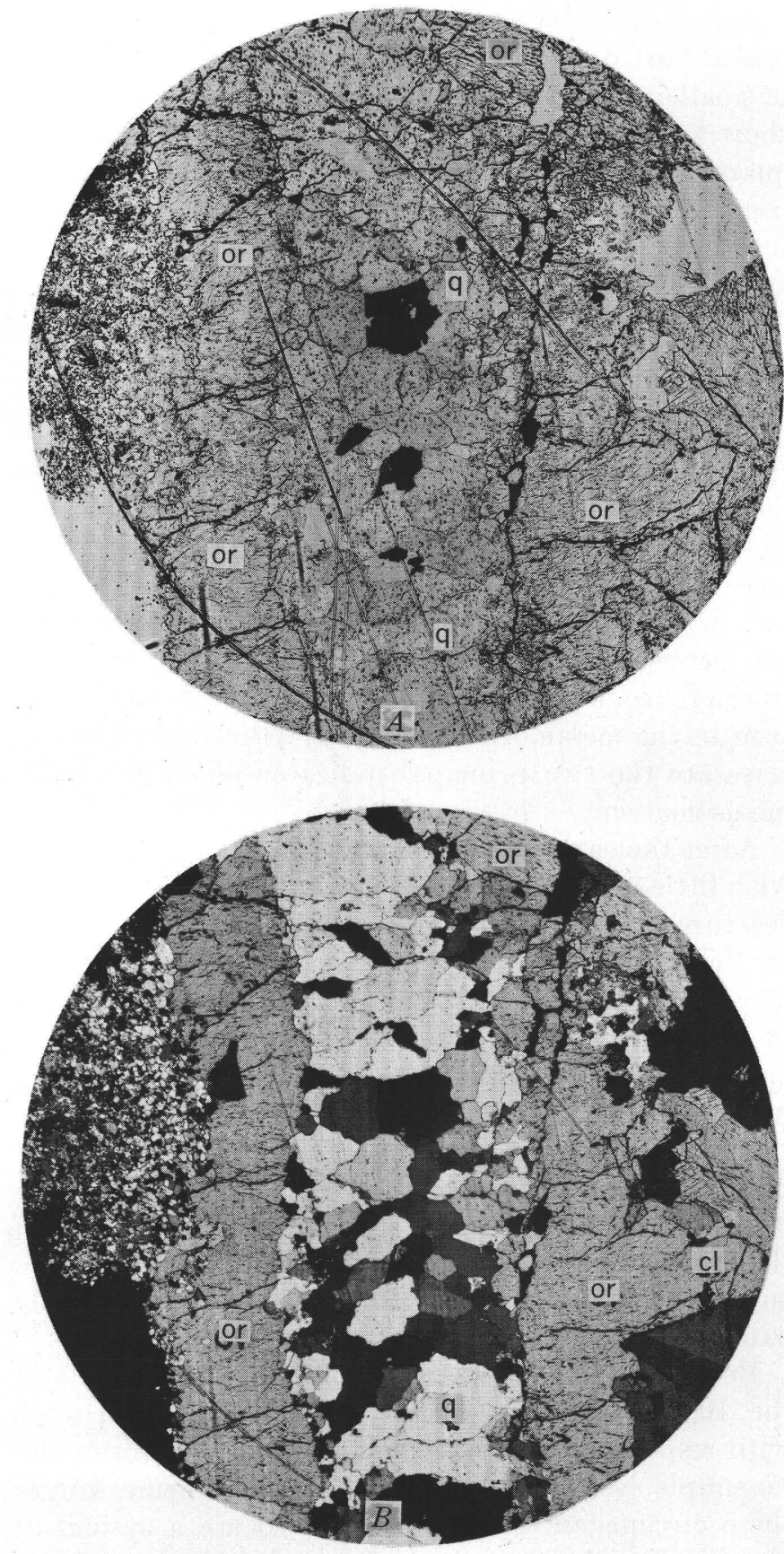

FIGURE 8.-Photomicrographs of quartz-orthoclase vein cutting quartzite of the Battle Formation; quartz (q), orthoclase (or), and chlorite (cl). Note hornfels in upper left. $A$, Plane polarized light. $B$, Crossed polarized light. $\times 22.9$.

index of refraction is $1.605 \pm 0.003$, which suggests an iron content of about 11 percent, based on comparison with biotite studies made by Anderson (Anderson, Scholz, and Strobell, 1955, p. 52). Sericite in contact metamorphosed rock is in anhedral aggregates largely confined to areas close to the intrusive contacts. Apatite is an important constituent of the tactite and hornfels in places; epidote and zoisite are abundant locally.

The siliceous wallrocks of the Pumpernickel, Har- 
mony, and Battle Formations in contact with intrusive rocks reacted in different ways. The shale and siliceous shale of the Pumpernickel Formation were metamorphosed to biotite hornfels, and chert was recrystallized to a rock having crystalloblastic texture resembling quartzite. Shale of the Harmony Formation likewise was metamorphosed to biotite hornfels; sandstone of the Harmony Formation was changed to biotite-quartzite. Under the microscope the biotite resembles closely the biotite of the calcareous wallrocks and also has a Y index of $1.605 \pm 0.003$. Another conspicuous constituent of the biotite hornfels is muscovite which probably formed at the expense of clastic orthoclase, microcline, and mica. Secondary orthoclase, mostly in small anhedral grains, also formed in feldspathic sandstone and arkose. Quartzite, originally sandstone and conglomerate of the Battle Formation that was low in iron, calcium, and magnesium was recrystallized during contact metamorphism; recrystallization to some extent made clastic texture less distinct, but the conglomeratic texture commonly persisted up to the intrusive contacts.

Of the ore minerals, probably only pyrite and small amounts of magnetite and scheelite were introduced during the contact metamorphic phase. These minerals occur in pockets and disseminated throughout the tactite and hornfels, and they are not spatially related to the other ore minerals. No sharp line can be drawn between the ensuing hydrothermal stage and the contact-metamorphic stage, however, and sulfides such as pyrrhotite and arsenopyrite may have been partly introduced during the transition from one stage to another.

\section{HYDROTHERMAL STAGE}

The hydrothermal stage probably followed contact metamorphism without a perceptible break, and many of the processes carried over from one to the other. The earliest recognizable event during the hydrothermal stage was fracturing and brecciation associated with early faulting along northwest trends that permitted introduction of solutions that caused alteration of the wallrocks and from which sulfides and gangue minerals later formed.

The first minerals that developed during alteration were chlorite and hydromica. The chlorite mostly formed from magnesium silicates of the contact metamorphic stage but was also deposited locally in veins (fig. $11 C$ ). The hydromica mainly replaced orthoclase in the contact metamorphic zone and orthoclase and plagioclase in the igneous rocks. ${ }^{1}$ The first minerals of the ore stage were quartz and molybdenite which mainly formed in veins. The quartz is typically anhe-

\footnotetext{
${ }^{1}$ Clement, S. C., 1961, Mineralogy of the Copper Canyon quartz monzonite porphyry, Lander County, Nevada: Salt Lake City, Utah Univ. M.S. thesis, 32 p.
}

dral, like the quartz deposited during the previous stage. The molybdenite occurs on small flakes intergrown with the quartz. Little alteration is observable along these veins.

The deposition of the quartz-molybdenite veins was followed, probably with no significant time interval, by that of the pyrite, arsenopyrite, pyrrhotite, sphalerite, and chalcopyrite. Not all these sulfides occur in the same ore body, and their exact sequence is therefore uncertain. Arsenopyrite, in crystals a quarter of an inch across, together with early pyrite and pyrrhotite form pods within hornfels at the Copper Canyon mine. This pyrite (fig. $5 B$ ) is commonly cubic in form and is coarse grained. Early quartz contemporaneous with arsenopyrite, pyrrhotite, and the early pyrite generally is in euhedral crystals an eighth to half an inch long; it coats fractures and fills cavities between breccia fragments ( fig. 9 and $10 \mathrm{~A}$ ). Chalcopyrite in the breccia ore fills cavities between the other sulfides and is anhedral. Chalcopyrite began to form early in the hydrothermal stage and continued late. It is associated both with the early pyrite (fig. $5 B$ ) and with the later pyrite. In the Iron Canyon mine, chalcopyrite, pyrrhotite, and sphalerite (fig. $10 \mathrm{~B}$ ) are so intimately intergrown as to suggest simultaneous crystallization. In the Copper Canyon mine, sphalerite and galena are closely associated and fill spaces between quartz crystals (fig. 9). Deposition of sphalerite began before that of galena, and ended before deposition of galena ceased. Simultaneous with and following the formation of the galena, a later generation of pyrite, characterized by lacy struc-

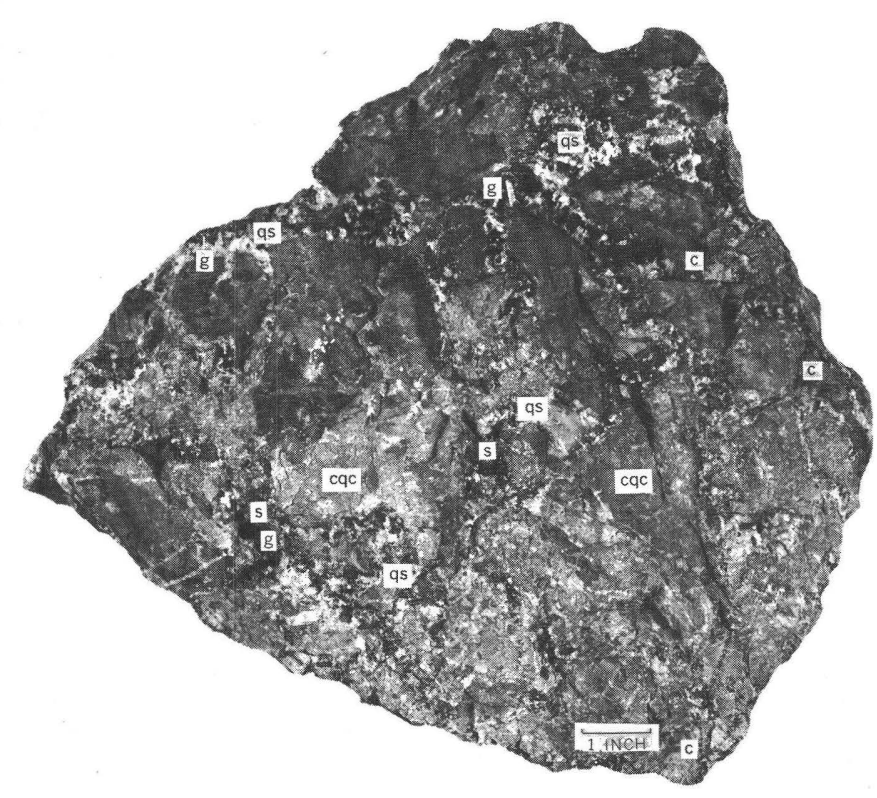

FiguRE 9.-Specimen of breccia ore, 700-level stopes, Copper Canyon mine; fragments of chloritized quartzite conglomerate (cqc) are cemented with quartz-siderite veins (qs) that locally contain pockets of chlorite (c), galena (g), and sphalerite (s). 2/3's natural size. 

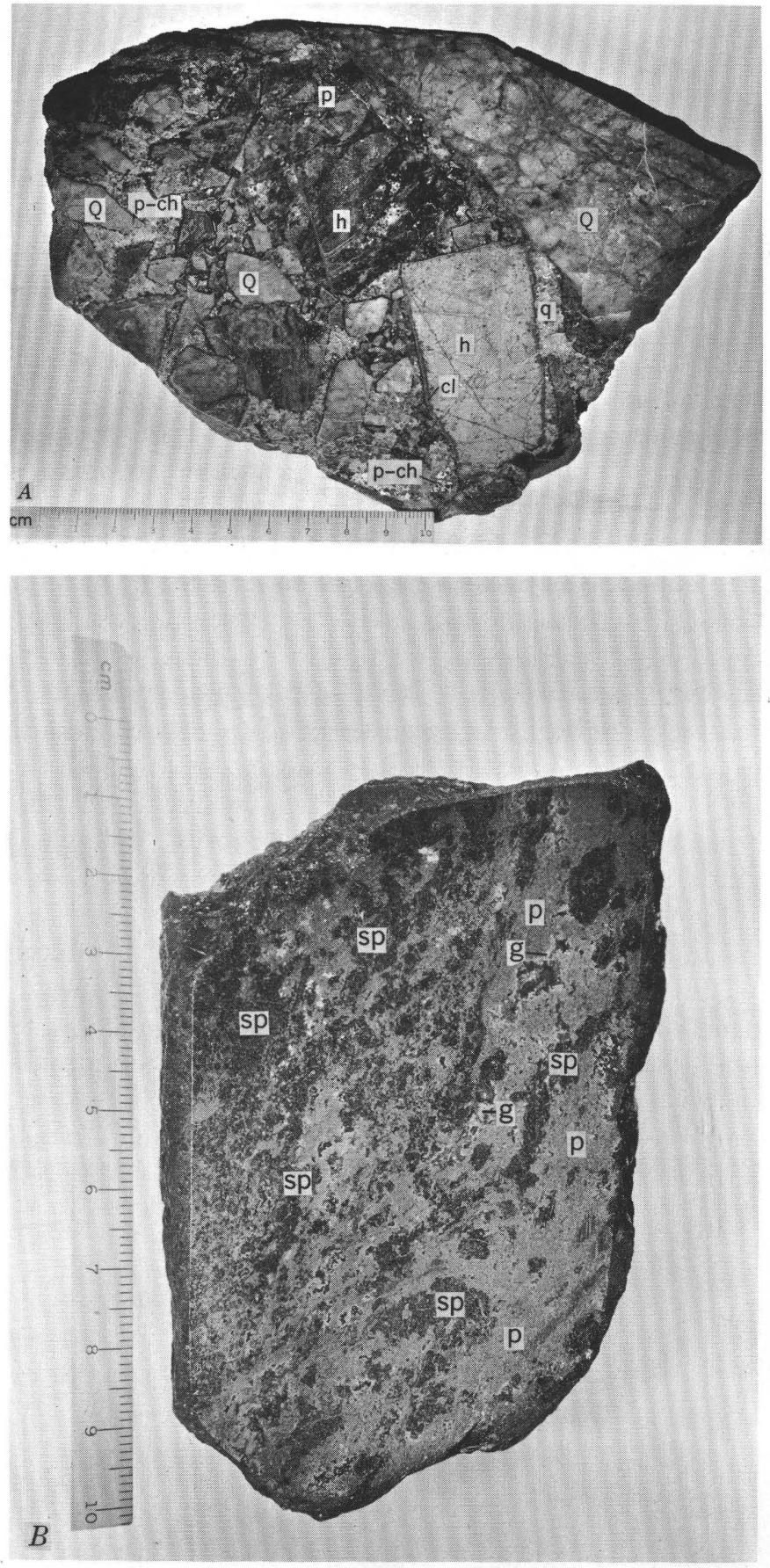

Figure 10.- $A$, Polished specimen of breccia ore, Copper Canyon mine. Hornfels $(h)$, quartzite $(Q)$, quartz $(q)$, chlorite $(c l)$, and late pyrite-chalcopyrite (p-ch). $B$, Polished specimen of massive sulfide ore, Iron Canyon mine. Pyrite and pyrrhotite $(p)$, sphalerite $(s p)$, and galena $(g)$.

ture and pyritohedral and octahedral crystal form, was deposited (fig. 11A). The late pyrite is locally intergrown with chalcopyrite (fig. $11 D$ ); this feature suggests that chalcopyrite deposition spanned a large part of the hydrothermal stage. Gold also accompanies late pyrite (fig. $11 B$ ).

Calc-silicate minerals of the contact metamorphic stage were unstable during the early hydrothermal stage, and such minerals as biotite, diopside, actinolite, garnet, epidote, and zoisite were altered to chloriteclay mineral aggregates. Breccia fragments were altered from the periphery inwards; chlorite rosettes were formed at the contacts between fragments and quartz veins (figs. $10 A, 11 C$ ). This suggests solution and redeposition of the chlorite. The beginning of the formation of chlorite may have in part preceded the hydrothermal stage and may more properly belong to the latest part of the contact metamorphic stage.

During the later part of the hydrothermal stage, sulfide deposition continued with low-temperature forms that included marcasite, tetrahedrite, and boulangerite. Marcasite at the Copper Canyon mine is a common constituent of pyritic ore where it fills spaces between the other sulfides (fig. 11D) and may also replace earlier sulfides. Tetrahedrite, a constituent of many veins in central Nevada, occurs in two mines in the quadrangle, the O'Leary (Buckingham) and Little Giant, where it is a late constituent of hypogene ore. A mineral identified by Charles Milton as boulangerite(?) replaces galena peripherally at the Copper Canyon mine. Because siderite crusts coat all the sulfides of the early hydrothermal stage at the Copper Canyon mine, it is assigned to the late hydrothermal stage. The siderite is widespread throughout the district, but is nowhere abundant.

\section{SUPERGENE MINERALIZATION}

Upon the advent of downward penetrating ground waters, the copper-gold replacement deposits underwent a series of changes during the supergene mineralization stage. These changes include oxidation and removal of some metals above the water table and enrichment of copper and silver at or near the water table. Upon oxidation, the pyrite and other sulfides yielded sulfuric acid which reacted with minerals formed during the contact metamorphic and hydrothermal stages; some constituents remained in the oxidized zone, and others were leached and carried downward in solution. Along with the supergene alteration of sulfides, many silicate minerals were altered to clay minerals such as halloysite, montmorillonite, kaolinite, and illite.

One of the more mobile elements in the oxidized zone was copper. Copper was present in the primary ore as chalcopyrite; when it was oxidized, the copper moved out in the acid solutions, leaving an iron oxide boxwork in the cavity. On the way downward part of the copper was oxidized to malachite and azurite in the presence of carbonate or to chrysocolla in the presence of silica. Copper that reached the sulfide zone at the water table precipitated as coatings of chalcocite-covellite on pyrite and chalcopyrite (fig. $12 A$, and $13 B$ ); 

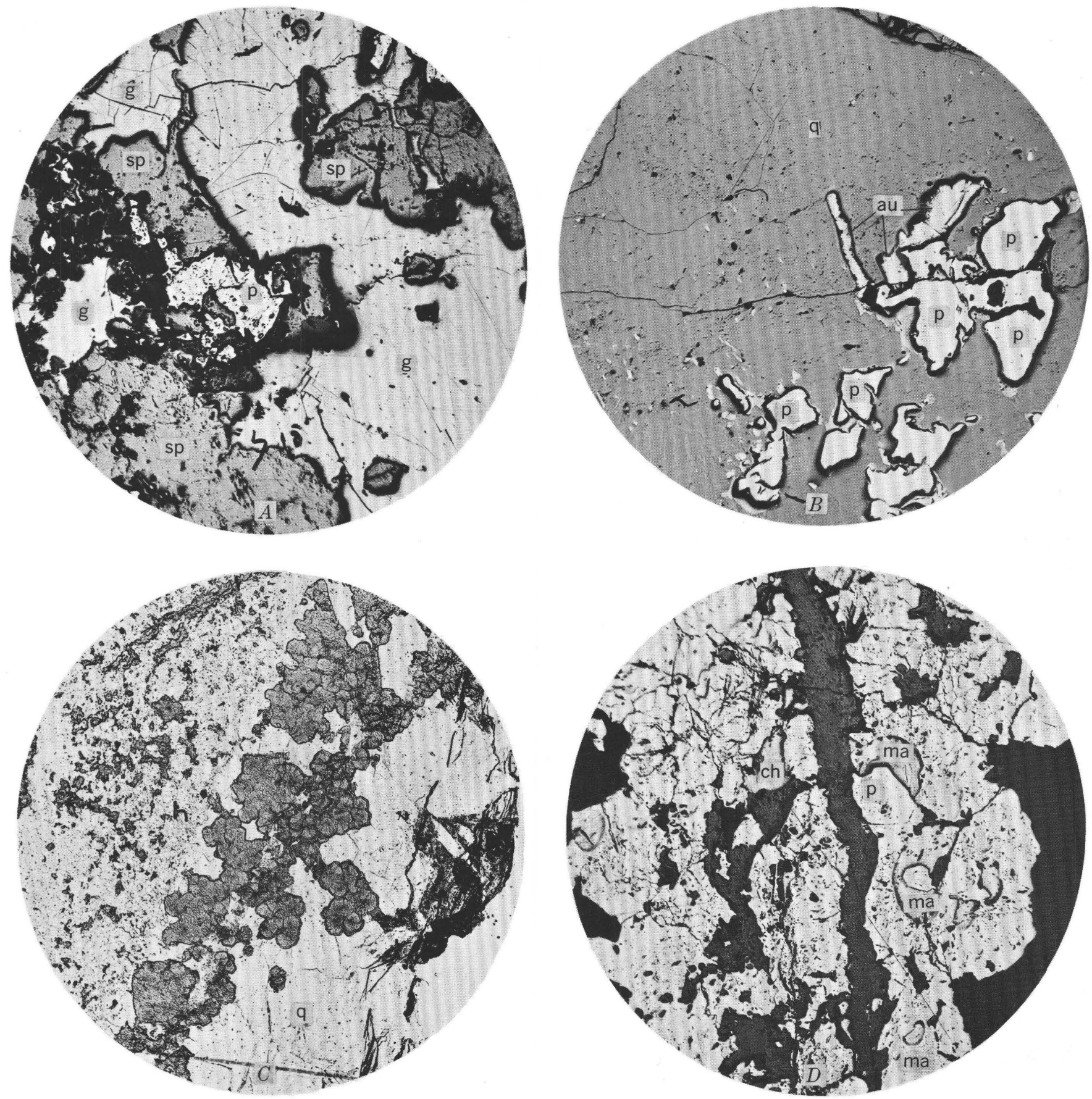

FIGURE 11-Photomicrographs of replacement minerals formed during the hydrothermal stage, $A$, Complex sulfide ore, Copper Canyon mine; shows intergrowth of galena $(g)$, sphalerite $(s p)$, and late pyrite $(p)$. Plane light, $\times 15.5 . \quad B$, Gold ore, Copper Canyon mine; amethystine quartz (q) with late pyrite (p) and gold (au). Plane-polarized light, $\times 15.5 . \quad C$, Chlorite rosettes between quartz vein $(q)$ and garnet-diopside hornfels of the Battle Formation (h). Plane light, $\times 22.9$. $\quad D$, Pyritic ore, 500 level, Copper Canyon mine; mainly late pyrite (p) with a little chalcopyrite (ch) and patches of marcasite showing colloform structure (ma). Plane-polarized light, $\times 15.5$.

native copper was formed also locally. As the oxidized zone moved downward, the chalcocite oxidized first to cuprite, then to malachite, azurite, and chrysocolla (fig. $12 B)$. In places such enriched ores which were mined during the early days of the district contained as much as 30 percent copper.
In Copper Basin the oxidation and enrichment took place mainly prior to eruption of the quartz latite, possibly while the relief in the range was low. At this time the climate was more humid than at present and deep weathering occurred. Copper was carried downward and precipitated at the water table. The quartz latite 

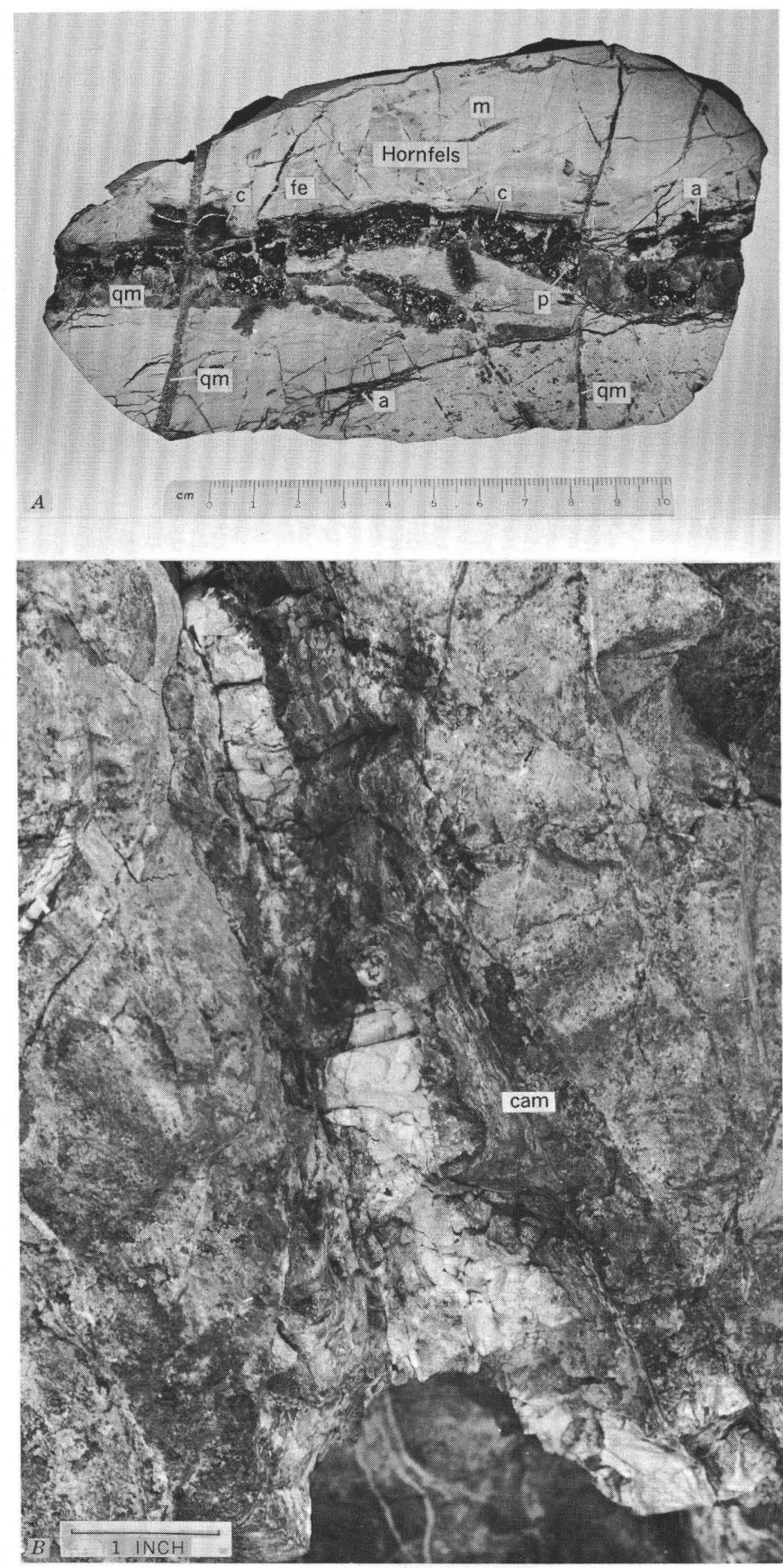

FigURE 12.- $A$, Polished specimen of chalcocite-pyrite-carbonate ore in hornfels of the Battle Formation, Copper Canyon mine; chalcocite (c) commonly rimmed by cuprite, residual pyrite $(p)$, azurite $(a)$, malachite $(m)$, quartz-malachite veins $(\mathrm{qm})$, and iron oxides (fe). $B$, Chrysocolla-azurite-malachite (cam) vein with clay minerals (white) on the Uncle Tom claim. Wallrock is Harmony Formation.

cover subsequently prevented much further oxidation until erosion during the canyon-cutting cycle exposed the lodes.

Silver was enriched also in the upper parts of the ore bodies. In part, the enrichment was due to the removal of soluble constituents, but in part silver was carried in solution and was redeposited as native metal or as complex sulfides of silver, antimony, and arsenic. In general the silver enrichment was confined to the upper parts of the ore bodies.

Other minerals that formed in the oxidized zone were iron oxides and scorodite from arsenopyrite and pyrite; cerussite and anglesite from galena; smithsonite and hemimorphite from sphalerite; goslarite, zinc sulfate, is found locally. Gypsum is abundant in the oxidized zone along with iron oxides ranging from light yellow to dark brown in porous to compact masses. Sulfates such as chalcanthite, pisanite, and melanterite are widely distributed throughout the stopes and on the walls of drifts (fig. 6).

Aluminum silicates were altered also by the acid solutions during oxidation of the ore bodies. Jarosite, together with other ferrous-ferric sulfate minerals, was one of the sulfate minerals formed throughout the oxidized zone. Among the clay minerals that were formed are halloysite, kaolin, illite, richellite, montmorillonite and other unidentified clay minerals.

The sequence of formation of minerals during the hypogene and supergene stages is summarized in figure 7. Not all these minerals are found in every vein, and the sequence shown represents a synthesis of veins in the Copper Canyon area.

\section{SUPERGENE COPPER DEPOSITS}

The supergene copper deposits are typically poor in gold and silver. This is in sharp contrast to the copper ores relatively rich in gold and silver from such primary deposits as those of the Carissa and Copper King of Copper Basin and the Copper Canyon ore bodies. The copper deposits at the Sweet Marie and Contention mines are good examples of the supergene type. In them the principal copper mineral is chalcocite, which, together with a little cuprite, chrysocolla, malachite, and azurite, makes up the ore.

The supergene copper bodies were formed from hypogene copper ore bodies deposited during the contact metamorphic and hydrothermal stages. These copper ore bodies were oxidized and the copper transported downward in solution where it was precipitated in part by replacing pyrite and in part was oxidized to chrysocolla, cuprite, malachite, and azurite. During subsequent erosion, the remnants of the hypogene ore bodies were removed, and only the supergene deposits were left.

The environment in which the supergene copper was deposited originally consisted largely of biotite hornfels and quartzite which were cut by quartz monzonite bodies. The hornfels was a hard dense rock containing considerable pyrite through which supergene solutions moved slowly. The quartzite and quartz monzonite were apparently more brittle and prior to or during the 
course of mineralization were fractured, this fracturing permitted easy access to supergene solutions. Copper ore in the hornfels was mainly chalcocite, and ore in the quartzite and quartz monzonite was mostly malachite, azurite, and chrysocolla.

Wallrock adjacent to the supergene copper bodies has undergone intense attack by acid waters derived from the oxidation of pyrite. Clay minerals formed during this alteration include kaolin, halloysite, richellite, and other unidentified minerals. Jarosite is widely distributed throughout the altered zone, where it commonly is associated with iron oxides. Turquoise is present in several deposits, and material of jewelry grade has
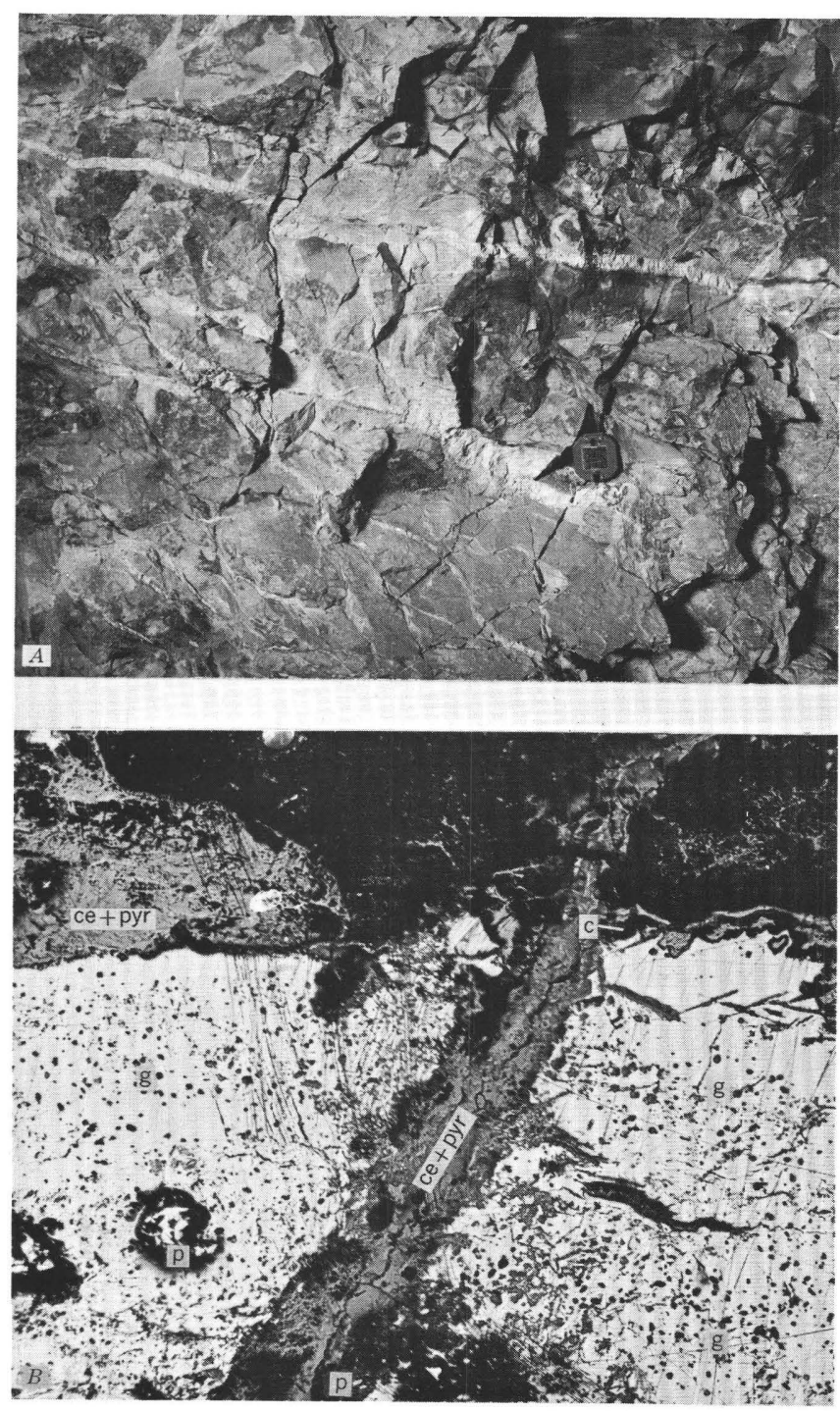

Figure 13.- $A$, Veinlets of clay minerals and turquoise cutting hornfels of the Harmony Formation, Blue Gem Turquoise mine. $\quad P$, Photomicrograph of high-grade silver ore, Little Giant mine; mainly galena ( $\mathrm{g}$ ) with included blebs of polybasite(?) cut by vein of cerargyrite (ce) and pyrargyrite(?) (pyr). Intergrown cerargyrite and pyrargyrite(?) in upper left, chalcocite-covellite (c) in upper right, and early pyrite $(p)$ in left lower center. Plane light, $\times 15.5$ been mined from the Blue Gem Turquoise mine (figs. $13 A, 14)$.

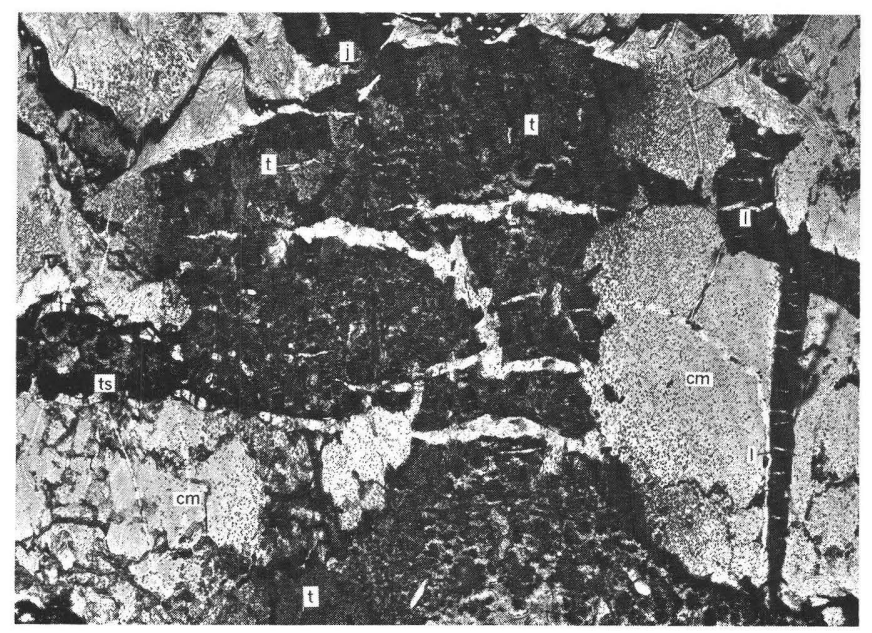

Figure 14.-Photomicrograph of turquoise ( $t$ ), Blue Gem Turquoise mine, in veinlet cutting clay minerals $(\mathrm{cm})$ and in spherulites (ts); the dark areas at top and side are veins and masses of jarosite (j) and limonite (I). Plane-polarized light, $\times 25$.

\section{COPPER-GOLD VEINS}

Copper-gold veins follow faults and fissures in and near the replacement deposits. In general, the mineralogy of the veins is similar to that of the replacement deposits, and in places it is evident that the veins were the feeding channels for the replacements.

Some of the veins are tightly frozen to the walls and represent simple fissure fillings; others are along faults that underwent movement during or after vein formation and are now bounded by shear zones on one or both walls. Most of the copper-bearing veins are small, but a few such as the Virgin, Estes, and Superior veins in the Copper Canyon mine (pl. $8 A$ ) have had notable production, especially in the enriched zone. The Virgin vein was stoped for a strike length of 600 feet and down dip for 450 feet; stopes on the vein are as much as 20 feet wide, but ore widths are reported usually to have ranged from 1 to 5 feet.

\section{HYPOGENE STAGE}

The wallrocks adjacent to the veins were sericitized, chloritized, and silicified during vein formation and were subsequently altered to clay minerals during oxidation. The sequence of deposition of sulfides in the veins appears to follow closely the sequence in the copper-gold replacement deposits. Pyrite, molybdenite, arsenopyrite, and pyrrhotite, accompanied by quartz, appear to be the first sulfides; sphalerite, chalcopyrite, and galena followed closely after them. The pyrite tends to be in coarsely crystalline aggregates having cubic crystal habit. Arsenopyrite is generally fine grained and is intergrown with pyrite, Pyrrhotite, in finely granular 
masses, is locally intergrown with chalcopyrite; thus, in part at least, they probably crystallized together. The sphalerite is dark brown to black, like the pyrite of the replacement ore bodies; the galena is intimately intergrown with sphalerite and is generally coarsely crystalline. Siderite, in veins and cavity fillings, appears to be the latest hypogene vein mineral in the copper-gold veins.

SUPERGENE STAGE

During supergene mineralization the copper-gold veins were enriched in both copper and gold. The upper parts of the veins were leached by acid solutions, and the copper was transported downward and deposited as chalcocite and covellite replacing pyrite and other iron-bearing sulfides (figs. $12 A, 13 B$ ). In places the chalcocite-covellite was oxidized to cuprite, azurite, malachite, and chrysocolla.

The upper oxidized parts of the vein contain the same suite of minerals as the oxidized replacement deposits.

\section{GOLD-SILVER DEPOSITS}

Gold-silver veins such as in the Buzzard, WilsonIndependence, Plumas, and Eldorado mines, have yielded a small production. The ore shipped from these deposits has come mainly from the oxidized zone where enrichment of the gold has been effected by removal of soluble constituents such as iron and sulfur. Most of the veins are narrow, ranging in width from less than 1 foot to 5 feet; the ore bodies tend to be pockets that do not persist far along either the strike or dip. The gold-silver veins are peripheral to the copper-gold deposits and are bordered by the silver-lead-zinc vein zone (fig. 15).

Alteration along the walls of the gold-silver vein is similar to the alteration adjacent to copper-gold veins, but in general is less intense. The ore minerals include pyrite and arsenopyrite, which are variable in amount from one vein to another and are accompanied by minor amounts of sphalerite, galena, and chalcopyrite. Quartz in the veins is mostly coarsely crystalline, rarely showing comb structure, and is generally much brecciated.

The grade of the gold-silver ore varied widely. Highgrade ore mined from the upper part of the Buzzard vein in 1936 averaged 2.8 ounces of gold and 32 ounces of silver to the ton. Ore mined at the WilsonIndependence mine between 1955 and 1957 averaged 1.75 ounces of gold and 50 to 55 ounces of silver to the ton. Normally, gold cannot be seen with the unaided eye in the ore, but it can be concentrated by panning after crushing; the gold evidently occurs finely disseminated throughout the sulfides. A notable exception is the Nevada-Omaha vein in Philadelphia Canyon which contained a gold-quartz streak as much as 2 inches wide.

\section{LEAD-ZINC-SILVER DEPOSITS \\ REPLACEMENT DEPOSITS}

The principal lead-zinc-silver deposits are in the Galena and Copper Canyon areas. The Hornfels ore body in the Copper Canyon mine is the largest of the replacement bodies, but there are also replacement deposits adjacent to faults in the Galena area.

The Hornfels ore body was localized in calcmagnesian-silicates and siliceous hornfels of the middle member of the Battle Formation between the 500 and 700 levels of the Copper Canyon mine. The early history of the formation of the lead-zinc deposits closely parallels the history of the copper replacement deposits; both began with a contact-metamorphic stage and ended with a hydrothermal stage. Inasmuch as the Hornfels ore body is well below the zone of oxidation, there has been no supergene mineralization.

CONTACT-METAMORPHIC STAGE

The calcareous units of the Battle Formation on the 700 level of the Copper Canyon mine have been metamorphosed to diopside-actinolite hornfels and siliceous hornfels (figs. 9 and 10A). Scheelite, accompanied by quartz and pyrite, is widely distributed throughout the workings in small pockets and was formed also during the contact-metamorphic stage.

\section{HYDROTHERMAL STAGE}

The sulfide minerals of the lead-zinc-silver replacement bodies are the same as those in the copper-gold replacement bodies except that they are present in quite different proportions. In the lead-zinc bodies, chalcopyrite and pyrite are subordinate to sphalerite and galena; the gold content is lower and the silver content is higher. In about 300,000 tons milled, the tenor in lead has averaged 1.5 percent; in zinc, 1.2 percent. Silver has averaged 2.0 ounces and gold 0.06 ounce to the ton.

The Hornfels ore body was localized in a wedgeshaped block between the Gulch and West faults (pl. $9 D)$. The rock in the wedge was thoroughly crushed and broken, and the cavities between fragments were filled with quartz, sulfides, and siderite (figs. 9, 10A).

\section{VEINS}

The lead-zinc-silver fissure veins that have been productive are mainly in Galena Canyon and adjacent areas. The major production has come from the White and Shiloh and Trinity veins; the Nevada and Lucky Strike veins also have significant production. These are all within prominent north-trending fault zones on 
the fringe of the copper-gold zone (fig. 15). They contain variable amounts of pyrite, sphalerite, galena, silver, and gold in a quartz-calcite gangue. During the early days attention was paid chiefly to the silver-rich zones near the surface, but in recent years they have been exploited mainly for lead and zinc.

The fissure veins range from a few inches to 3 feet in width and have been traced for thousands of feet along the strike. Ore shoots are commonly distributed sporadically along the veins. The principal ore shoot on the Trinity vein was 400 feet long and was mined down dip from the surface to the adit level (pl. 13) about 150 feet below; the ore body extends below the adit level, but has not been exploited there.

Little is known about the grade of high-silver ore mined during the early days except that assays of 200 ounces silver a ton were common, and some higher assays have been reported (Whitehill, 1873). Lead-zincsilver ore that has been mined during recent years appears to fall in the range of 2 to 10 percent lead, 5 to 20 percent zinc, and 10 to 20 ounces of silver to the ton.

The lead-zinc fissure veins are in north-trending fault zones that probably formed prior to the intrusion of granitic rocks, for some of the faults contain quartz monzonite for part of their length. Movement along the faults continued during vein formation as the early quartz and sulfides are commonly brecciated and are recemented by later quartz and sulfides.

HYPOGENE MINERALIZATION

The wallrocks near the lead-zinc veins are commonly altered adjacent to the veins in zones a few inches to several feet wide. In some places the wallrocks have been partly replaced by quartz or calcite, but generally the rock has been bleached and altered to clay minerals.

Commonly two periods of vein formation can be distinguished in most veins. During the first period, quartz, pyrite, and arsenopyrite were introduced. The quartz of the first period is generally granular and rarely shows comb structure. It is associated with euhedral cubic pyrite and arsenopyrite, locally coarsely crystalline. These minerals have been fractured and brecciated during a second period in which the vein was reopened, and sphalerite, galena, chalcopyrite, and later pyrite were introduced. The sphalerite is dark brown and is in coarsely crystalline masses (fig. $5 B$ ); the galena is in tiny blebs in the sphalerite and also in crystalline masses intergrown with sphalerite. Siderite, and less comonly barite, are constituents of some veins.

\section{SUPERGENE MINERALIZATION}

Oxidation of the upper parts of the lead-zinc-silver veins has formed several secondary minerals, carbon- ates, sulfates, silicates, and oxides near the surface, and supergene sulfides near the water table.

The most important secondary lead mineral in the oxidized zone is cerussite which commonly forms "sand carbonate" pods and veins. Anglesite is found locally as coatings on relict galena nodules. Secondary zinc minerals are hemimorphite, smithsonite, and hydrozincite. Hemimorphite appears to be the most abundant of these. Cerargyrite and native silver have been reported from the White and Shiloh mine where they were important constituents of the oxidized ore. Limonite and hematite are the principal iron oxides in the upper parts of the veins; melanterite is a common coating on the walls of stopes and drifts. Goslarite and gypsum are abundant locally.

Secondary silver sulfides were formed below the zone of oxidation in some veins, such as the White and Shiloh and the Little Giant. Galena is partly replaced by argentite, polybasite, proustite, and cerargyrite (fig. $13 B)$. These minerals are generally found in pockets which were the source of the rich silver ores mined during the early days of the camp; these ores gave assays from $\$ 100$ to $\$ 1,000$ a ton and averaged about $\$ 300$ (Hague, 1870, p. 318).

\section{ANTIMONY DEPOSITS}

Antimony-bearing veins occur in the outer zone of ore deposits in the Galena Canyon area between Copper Canyon and Copper Basin. For the most part, the veins are narrow and lenticular and production has been small. The Apex Antimony mine, which has shipped about 150 tons, leads the district in production of antimony ore. The antimony-bearing veins are composed largely of quartz, stibnite, and pyrite. Near the surface the stibnite has been oxidized to antimony oxides of the stibiconite group. Some of the oxidized ore mined during the 1860's was high in silver, but none of the primary ore has yielded notably high silver assays.

\section{ZONAL ARRANGEMENT OF ORE DEPOSITS}

By plotting the ore deposits according to metal associations, a zonal arrangement roughly surrounding the igneous intrusive rocks becomes apparent (fig. 15). The zonal arrangement of deposits outlines two centers of intrusion, one in the Copper and Galena Canyons area and the other in the Copper Basin area.

This plotting of the ore bodies shows a zonal pattern having copper-gold and copper deposits at the center, peripheral gold-silver and lead-zinc-silver deposits in a middle ring, and antimony deposits scattered beyond this.

\section{COPPER-GOLD AND COPPER DEPOSITS}

The copper-gold deposits in the central zones are associated with the highest grade of igneous metamorphism 


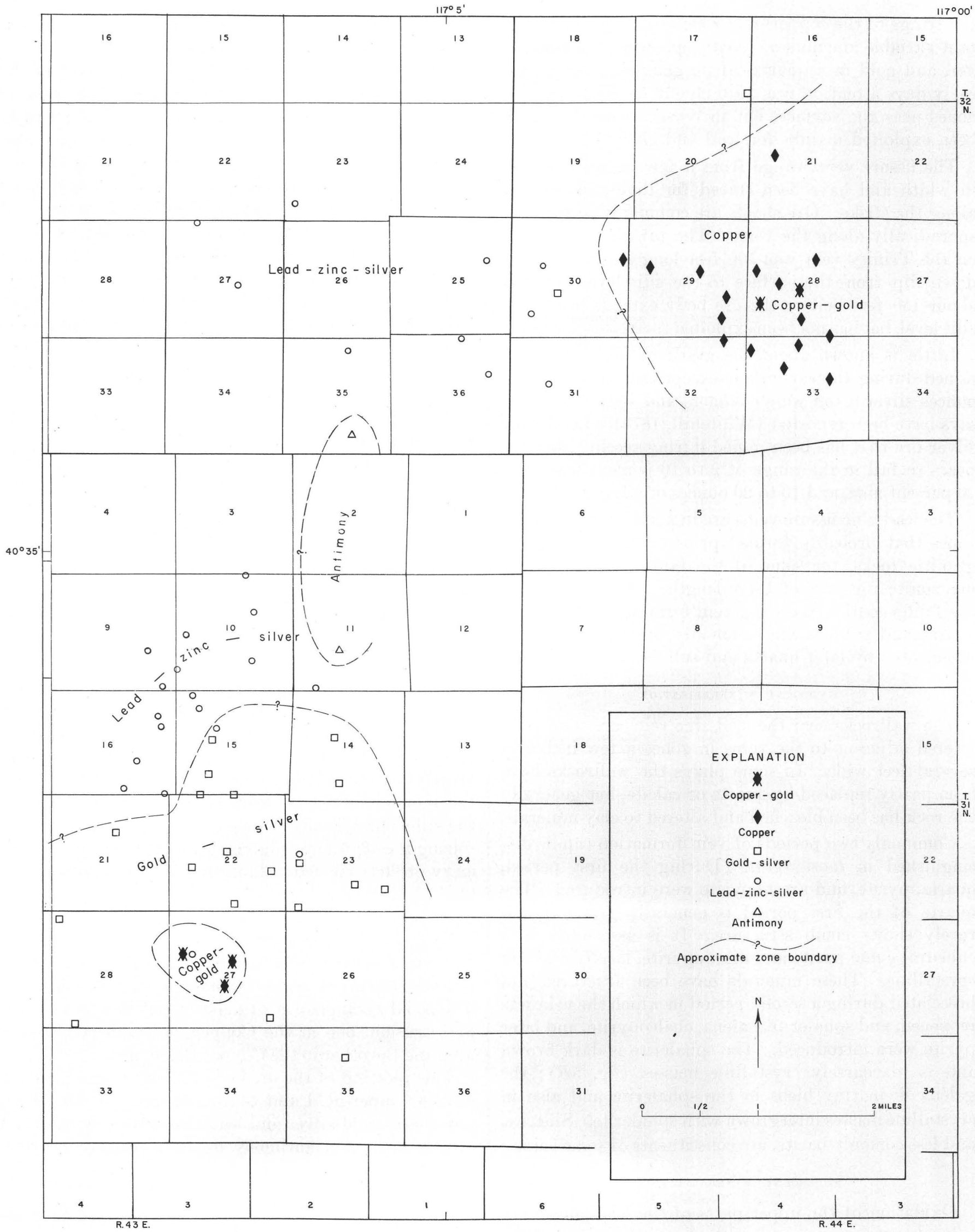

Figure 15.-Map showing zoning of mineral deposits, Battle Mountain district. 
around the intrusive stocks and related bodies. Typical sulfide minerals of the central zone include pyrrhotite, arsenopyrite, pyrite, and molybdenite; scheelite is present locally. The gangue minerals include garnet, diopside, amphiboles, and related minerals which were formed during contact metamorphism. The sulfide minerals, such as chalcopyrite, sphalerite, galena, and lacy pyrite, were introduced later during the hydrothermal phase. Lead-zinc deposits, such as the Hornfels ore body at Copper Canyon mine and the Iron Canyon mine, are also found in the inner zone, but only in calcareous host rocks. Chalcopyrite is locally an important constituent of these bodies, but the copper content is distinctly lower than the copper-gold ore bodies.

Copper deposits in Copper Basin that surround the central zone copper-gold deposits are mostly supergene deposits and are therefore shown by a separate symbol on figure 15 .

\section{GOLD-SILVER DEPOSITS}

The inner part of the middle zone includes the goldsilver deposits that contain only sporadic shoots of copper, lead, and zinc minerals. Deposits characteristic of this type may be found in the area between Copper Canyon, Galena, and Galena Canyon. Pyrite and small amounts of pyrrhotite and arsenopyrite were the most abundant sulfides; quartz was the principal gangue mineral. The ore bodies were workable where gold and silver were enriched by the leaching away of the iron and other constituents.

\section{LEAD-ZINC-SILVER DEPOSITS}

The lead-zinc-silver deposits in the outer part of the middle zone are in Galena Canyon, on the outskirts of Copper Basin, and in the central part of the range. The principal sulfide minerals are sphalerite, galena and pyrite; chalcopyrite, arsenopyrite, pyrrhotite, and tetrahedrite are present locally. Silver, which is mainly in galena, is an important constituent of these ores. In general, the silver content seems to increase toward the outer boundary of the zone, and lead and zinc seem to decrease. The gangue minerals are quartz and locally calcite. The deposits are largely in fault zones or, to a lesser extent, along bedding adjacent to the faults.

The lead-zinc-silver deposits are, in part, along the strike continuations of faults that contain pyritic gold ores. It is not known whether the change in metallization is abrupt or gradational, but as the mineralogy is similar, it is probable that the change is gradational.

\section{ANTIMONY DEPOSITS}

The deposits containing antimony minerals are scattered throughout peripheral areas and are associated with lead-zinc-silver deposits. The antimony deposits have been worked for both their antimony and silver content. They occur in fault zones and are mineralogically simple; stibnite and pyrite are the sulfide minerals, quartz is the gangue mineral.

Bismuth and telluride minerals have been reported from some veins; the primary bismuth mineral is not known. Tellurium-bearing minerals include petzite and a member of the josëite-tetradymite group, accompanied by pyrite.

\section{AGE OF THE MINERALIZATION}

Ferguson (1929, p. 115) pointed out "that four epochs of ore deposition are represented in Nevada; the earliest ore deposits are associated with granitic rocks which, in western Nevada, were intruded near the close of the Jurassic and in eastern Nevada at the beginning of the Tertiary. Other ore deposits are associated with late Tertiary flows of two ages."

New data based on lead-alpha determinations of the ages of the intrusive rocks in Nevada by the U.S. Geological Survey may modify these age assignments somewhat. R. E. Wallace (oral commun., 1960) reports intrusive rocks of Permian age in the West Humboldt Range; Hotz and Willden (1964, p. 43, 51) report intrusive rocks of Late Cretaceous to early Tertiary age (45 to 70 million years) in northwestern Nevada. Much additional information will be needed to assign the major ore deposits in Nevada to one or another of these intrusive epochs. At present it appears that most of the intrusive bodies in Nevada were emplaced in Late Cretaceous and early Tertiary.

The ore deposits in the Battle Mountain district are closely related spatially to stocks of early Tertiary age. The ore bodies are partly within the contact aureoles of the rocks and in faults that cut the stocks, and it is inferred that the ore was formed during and immediately after the emplacement of the stocks.

\section{GEOCHEMICAI PROSPECTING}

During the fieldwork in the Antler Peak quadrangle, a series of soil samples was collected and analyzed to determine whether mineralized faults contain anomalous quantities of metals beyond known ore bodies. Four faults, the Trinity, Lucky Strike, Plumas, and Hayden, were sampled for an aggregate distance of 51/4 miles. The work was divided into two stages: an initial reconnaissance stage of sampling at points 50 feet on either side of the faults at intervals of 100 feet along the strike; and a later stage of detailed resampling of four promising areas at points 25 feet on either side of the faults at intervals of 50 feet along the strike. In a few places additional samples were taken on 20- to 25 -foot centers to determine the distribution of anomalies in mineralized areas. During the reconnaissance 
stage, 4-ounce sieve samples were taken at points 4 inches below the surface; the samples collected during resampling were composite samples taken at three separate places about 12 inches apart at the same depth.

The samples were analyzed for trace amounts of lead, zinc, silver, and antimony. The background (average metal content of soil in the absence of mineralization) of the different soils according to original rock type and the range in parts per million of the soil samples collected along the different faults are tabulated as follows:

Background content of lead, zinc, silver, and antimony, in parts per million, in the Antler Peak quadrangle, Nevada

[Analysts: Albert Marranzino and H. E. Crowe, U.S. Geol. Survey]

\begin{tabular}{|c|c|c|c|c|}
\hline Formation & $\mathrm{Pb}$ & $\mathrm{Zn}$ & $\mathrm{Ag}$ & $\mathrm{Sb}$ \\
\hline $\begin{array}{l}\text { Harmony } \\
\text { Greenstone of the Scott Canyon. }\end{array}$ & $<20$ & $\begin{array}{l}100 \\
100\end{array}$ & $\stackrel{<0.2}{<.2}$ & $\begin{array}{l}30 \\
20\end{array}$ \\
\hline Chert of the Scott Canyon & $<20$ & 100 & $<.2$ & 10 \\
\hline
\end{tabular}

Range in content of lead, zinc, silver, and antimony, in parts per million, of soils along faults, Antler Peak quadrangle, Nevada

[Analysts: Albert Marranzino and H. E. Crowe, U.S. Geol. Survey]

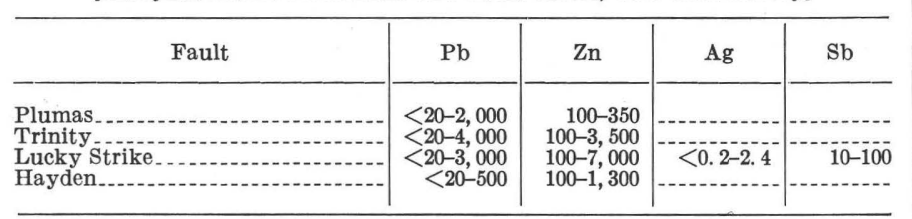

The ore bodies along the faults contain galena, sphalerite, pyrite, arsenopyrite, and in places a little stibnite and chalcopyrite. Quartz and a little calcite are the principal gangue minerals. The ore deposits were mined mainly for their gold and silver content in the oxidized zone, whereas in the sulfide zone the ore has been mined for the lead and zinc content as well. The ore occurs in roughly tabular bodies which range from 30 to 400 feet long, 2 to 10 feet wide, and are known to extend down dip from 50 to 250 feet. The controls which govern the location of most of the ore shoots along the faults cannot be detected in surface mapping.

As the lead-zinc ore bodies generally contain a high percentage of pyrite, the ground water in the vicinity of oxidizing ore bodies commonly has a high acidity and a high sulphate concentration (Morris and Lovering, 1952, p. 690). Zinc goes readily into solution in waters of high acidity and migrates away from the oxidizing ore body. As siliceous country rock forms the walls of most of the faults sampled, neutralization of the ground water migrating away from the ore bodies would be brought about mainly by dilution. In sulfate solutions of high acidity, lead is slightly soluble, but it is generally precipitated as lead sulfate as the solutions are neutralized during migration away from the ore body. Therefore a lead anomaly would be expected to occur near the primary deposit while a zinc anomaly might migrate a considerable distance from the primary source.

Because most of the geochemical prospecting was carried out along faults, the results are discussed separately.

\section{TRINITY FAULT}

The Trinity fault is a normal fault that strikes $\mathrm{N} .10^{\circ}$ to $30^{\circ} \mathrm{E}$. and dips steeply to the northwest. Generally the hanging wall is arkosic sandstone or shale of the Harmony Formation that has been downfaulted against chert, shale, and greenstone of the Scott Canyon Formation. In places along the strike, the Trinity fault splits and the Harmony or Scott Canyon Formation may form both the footwall and hanging wall of the fault. The Trinity fault extends from Galena Canyon northeastward about $11 / 2$ miles to the divide between Cow Canyon and Little Cottonwood Canyon.

Lenticular ore bodies which occur along the Trinity fault are comprised mainly of the ore minerals, galena, sphalerite, pyrite, and a little stibnite and chalcopyrite in a gangue of quartz and in places a little calcite. Near-surface oxidation of the deposits has produced typical secondary lead, zinc, and silver minerals. The Trinity fault has been explored rather extensively by underground workings at three different properties, but almost all the production has been from the Trinity mine. (See p. B59.)

The Trinity fault was sampled along its entire strike length of $1 \frac{1}{2}$ miles. The results of the work are shown on the sketch maps (pl. 4A). The soil along the fault ranges from a few inches to 4 feet in depth and averages about 2 feet; the slopes along the trace of the fault range from $3^{\circ}$ to $30^{\circ}$ and are mostly about $15^{\circ}$.

Several lead and zinc anomalies are shown on the geochemical map, the most noteworthy of which is nearly continuous for 1,600 feet along the fault. A northern group of anomalies envelopes the Trinity mine and extends 800 feet southwest of the mine workings. The most conspicuous features of the anomalies are the geochemical highs which extend southwestward from the Trinity mine and to the east of the fault strand marked by prospect pits and short adits. These highs are along a parallel fault strand which has not been explored to any great extent, and they may be the southward continuation of the fault strand which contains the ore bodies in the Trinity mine.

Areas underlain by the other anomalies are relatively small though they are of the same amplitude as the large anomaly. Inasmuch as any anomaly represents a zone of an abnormally high concentration of lead or 
zinc, the relative size is not considered critical, for a small anomaly might represent an extremity of a larger area of mineralization.

\section{LUCKY STRIKE FAULT}

The Lucky Strike fault can be traced from the intersection of the east and south forks of Trout Creek southeastward to the head of Little Cottonwood Canyon, a distance of about 1,000 feet. As it cuts only Harmony sandstone and shale, the trace can only be approximately located over most of the traced strike distance. Where the fault is exposed by mine workings, the strike ranges from N. $10^{\circ}$ to $40^{\circ} \mathrm{W}$. and the dip from $60^{\circ}$ to $80^{\circ} \mathrm{SW}$. Nearly all the production from the Lucky Strike fault has come from the Lucky Strike mine (see p. B78), and all the geochemical work along the fault was done in the vicinity of the Lucky Strike mine.

The ore bodies in the Lucky Strike mine occur as roughly tabular shoots along the fault. The ore bodies range from 30 to 100 feet long, 2 to 10 feet wide, and extend down dip from 50 to 250 feet. The ore is composed of galena, sphalerite, and pyrite; calcite and quartz are the principal gangue minerals. Oxidation of the ore bodies extended only a few feet below the surface.

The Lucky Strike mine workings explored four ore bodies which occur within an interval of 500 feet along the fault. Three of the ore bodies cropped out at the surface, the fourth reached a point 20 feet below the surface. The geochemical highs for lead and zinc which were found by the testing are shown on plate $4 B$. Some of the samples collected above the Lucky Strike ore bodies were analyzed for silver and antimony as well as lead and zinc. Trace amounts of antimony were found in only 8 of the 45 samples analyzed; in general the high silver anomalies correspond with the high lead anomalies.

\section{PLUMAS FAULT}

The Plumas fault is one of the most persistent highangle faults in the district. It can be traced from Galena Canyon southeastward to Box Canyon, a distance of more than 3 miles. South of the north fork of Iron Canyon, the fault splits into two nearly parallel strands. The average strike of the Plumas fault is $\mathrm{N}$. $10^{\circ} \mathrm{W}$. and the $\operatorname{dip} 65^{\circ}$ to $70^{\circ} \mathrm{SW}$.

Although most of the ore bodies which occur along the Plumas fault are classified as siliceous gold deposits, they all contain lead and some copper. The mineralogy of the ore bodies is described under the Plumas mine (see p. B55) and the Humbug-Lucky Chance mine (see p. B61), both of which are located on the Plumas fault north of Iron Canyon.
The total strike length of the Plumas fault was sampled during the reconnaissance phase; the sampling south of Iron Canyon, however, was done on the eastern strand of the fault.

Many geochemical anomalies were found by reconnaissance sampling along the Plumas fault (pl. $4 C$ ), but as only a limited time was allotted for the geochemical work, it was not possible to check all the anomalies during the resampling phase.

\section{HAYDEN FAULT}

The Hayden fault is a normal fault that strikes northeastward and dips steeply northwestward; it can be traced for about 2 miles from the Copper Canyon mine northeastward across the heads of the north fork of Iron Canyon and Butte Canyon.

Although no ore bodies of minable size have been found along the Hayden fault, it is believed to be one of the channelways for the mineralizing solutions which formed the ore bodies in the Copper Canyon and Independence mines. Many small pits and adits have been dug along the fault to explore gossans formed by the oxidation of pyrite and arsenopyrite.

Although only a few small anomalies were found along the fault (pl. $4 D$ ), the samples were consistently higher than background ( $\mathrm{Pb}$ five times background, Zn three times background).

\section{SUGGESTIONS FOR FURTHER PROSPECTING}

The Battle Mountain district has been thoroughly investigated over a long period of time by skilled prospectors, and probably all the exposed ore bodies have been discovered. Properties have been checked and rechecked by a steady procession of examining engineers and promoters, and most of them that warranted exploration have been explored. Where then, can new ore bodies be found? One way to search for ore is to test productive beds or structures along the strike or down dip from known ore bodies. Another way is to search for new beds and structures.

The search for ore in extensions of known productive beds or structures will require careful evaluation of the ore controls and of mineral zoning. For example, at the Copper Canyon mine the copper-gold ore is in the basal conglomerate of the Battle Formation, and the lead-zinc ore is in hornfels of the same formation. The ore was localized at the intersections of faults with these groups of beds. Such beds are the logical target areas both along the strike and down the dip; some of the faults that should intersect favorable beds outside the mine area have been mapped on the surface, but little is known as to their extent underground. Targets for exploration can be outlined in a general way, but they cannot be pinpointed. Slight changes in strike and dip 
of either faults or beds may cause apparent lateral displacements of projected target areas.

In addition, consideration must be given to the mineral zoning. From data assembled thus far, it appears that the major copper bodies were formed in the conglomerate in an inner metamorphic zone, and it is inferred that the copper content will decrease outward from this zone. At our present state of knowledge, it is impossible to predict where in the basal conglomerate of the Battle Formation additional copper bodies may be found. A likely area lies north of the intrusive body in Copper Canyon, in the same relative zone as at the Copper Canyon mine. The ore showings at the Independence mine to the east are low in copper, but possibly the copper was precipitated on deeper levels closer to the intrusive rock. The middle hornfels of the Battle Formation should also be tested in this area for lead-zinc mineralization.

The search for new beds and new structures that might contain workable ore bodies will require different techniques. In the preliminary geochemical studies of certain fault zones, it was demonstrated that geochemical prospecting will be a valuable tool in determining whether a fault zone is mineralized, and if so, where the best place to explore it might lie. This will require meticulous sampling of the fault zones and surrounding rocks, but such work will save time and labor in outlining the most likely target areas.

In the Copper Canyon mine the beds dip more steeply than the Virgin fault; thus, going westward, younger beds come into the footwall block. The Battle Formation should normally be overlain by the Antler Peak Limestone, and the limestone should come in the Copper Canyon mine area at about the 800 or 900 level. Inasmuch as calcareous beds are the main ore carriers in the mines, exploration to determine whether the Antler Peak Limestone is present in this area, and whether it is mineralized, may be warranted.

Another fault zone that may warrant further exploratory work in the vicinity of known deposits is the Virgin (Blossom) fault north of the Nevada mine. Here the hanging wall of the fault is the Antler Peak Limestone. Little work has been done along the fault zone here, and further exploratory work is suggested. At some future time it may also be worth while to drift southward from the Blossom mine to the Nevada mine along the fault. An attempt should be made to determine the depth to the Golconda thrust fault in this area in the hanging wall of the Virgin fault; in the lower plate of the thrust the Battle Formation, Antler Peak Limestone, and possibly Edna Mountain Formation would be found; any of these rocks could be ore bearers and should be tested at the most accessible point where mineralization is permissible.

Another intriguing possibility is that "porphyry" copper deposits may exist in the Battle Mountain district. Exploratory work by the Copper Canyon Co. suggests that most of the copper found thus far in intrusive rocks in Copper Basin is of supergene origin. However, large areas of pyritized ground in Copper Basin and also to the north and south are partly covered by alluvium and have been inadequately explored. These areas may locally contain pyritic copper deposits; additional work, guided by intelligently planned geophysical and geochemical groundwork, may be warranted in these areas.

The intrusive stock north of the Copper Canyon mine locally contains disseminated primary copper sulfides. The American Smelting and Refining Co. and the Duval Co. have been carrying on drilling programs to explore the distribution of these sulfides. Possibly exploratory work in intrusive bodies in Iron Canyon and adjacent areas may be warranted.

In addition, the senior author has pointed out the striking alinement of mining districts in north-central Nevada along northwest-trending belts (Roberts, 1960, p. B17; 1964). The Battle Mountain district occurs along the northwest extension of the Shoshone-Eureka belt (Roberts, 1960, fig. 9.1 and p. B19). It is inferred that the Roberts Mountains thrust lies below Battle Mountain at no great depth and that carbonate rocks form the lower plate below the thrust zone. The ore bodies that have been mined in the upper plate rocks are of significant size and may be indicative of significant ore bodies in crushed rock along the thrust plane and in the carbonate rocks below. Geophysical work to determine the depth of the thrust should be the first step in exploration. If the thrust is found at moderate depths, then likely areas could be tested with drill holes.

\section{HISTORY OF MINING}

The Battle Mountain district is one of the mining districts in Nevada that was discovered in the 1860's and has been intermittently productive to the present day. The first white men to visit this part of Nevada were the early explorers. The Humboldt River valley has been a favored route for travel across Nevada since 1825 when Jedediah Strong Smith and a company of 40 trappers traveled from Yellowstone Park to California and passed part of the way along the river (Vanderburg, 1939, p. 8). Smith named the river "Mary's River." Subsequently other explorers crossed the northern part of the state: among them were the Peter S. Ogden expedition sent out by Hudson's Bay Co. in 1831, Milton Sublette's expedition for the Rocky 
Mountain Fur Co. in 1832, Captain B. L. E. Bonneville and Joseph Walker's expedition in 1833, Thomas McCoy and Christopher (Kit) Carson's expedition also in 1833, the John Bidwell and J. B. Bartelson emigration party in 1841, and General John C. Fremont's expedition in 1843-44. Fremont renamed the river the Humboldt River after the famous German explorer.

The discovery of placer gold in California in 1848 caused heavy travel overland along the course of the Humboldt River, but there is no record that the gold seekers found any of the deposits so near their route of travel in Battle Mountain. The attention of miners was first attracted to Nevada by the discovery of rich silver deposits in the Comstock district in 1859. After this discovery, hordes of prospectors combed the Nevada hills; transportation and communication facilities were greatly improved during the next few years by the establishment of the Pony Express in 1860, the first transcontinental telegraph in 1861, the Overland Mail and Stage Route in 1861, and the completion of the Central Pacific Railroad in 1869.

According to Couch (in Couch and Carpenter, 1943, p. 71), Lander County was organized in 1862 and originally included about a third of the northeastern part of Nevada. The first mineral discovery in this part of Nevada was probably made at Austin, 90 miles south of Battle Mountain, in May 1862. The news of the discovery spread rapidly and by 1865 fully 60 mining districts had been organized in Nevada and 20,000 claims recorded. Between 1859 and 1890 there was more mining activity in Nevada than at any subsequent time.

According to Hill (1915, p. 71) and Raymond (1869, p. 118), the Battle Mountain mining district was organized in April 1867. Prior to this date, Messrs. Tanehill, Sinclair, and Heath had located claims in the area. The first claims were recorded in August 1866. The first exploratory work done in the district was probably on the Virgin vein in Copper Canyon. Hague $(1870$, p. 317$)$ reports that the Little Giant ore body was first explored in 1867 and production began in 1868 ; to July 1869 , the production totalled $\$ 70,000$. The Buena Vista mine also began production in 1868 . By 1870, 33 mines were in production, and two smelters having a combined daily capacity of 44 tons were in operation at Galena. In 1871, work on the Columbia and Mountain King antimony claims (now the Antimony King property) was begun. In 1876, a 30-ton concentrating plant equipped with jigs was erected at the mouth of Willow Creek to treat copper ore from Copper Canyon. Some properties were continuously active until 1900, but most ceased production by 1885 because the workings began to reach the sulfide zone, and the oxidized and enriched ore bodies were gradually exhausted. In 1909, placer gold discoveries at Bannock (now Philadelphia Canyon) caused a brief flurry of activity, and some of the lode mines were reopened the same year. In 1910, gold prospects in the Telluride area near the head of Rocky Canyon were discovered, but they have thus far yielded only a little production.

To 1940, Couch (in Couch and Carpenter, 1943, p. 73) records a total production from the district of 207,218 tons of ore that yielded $\$ 4,825,080$. These figures represent only a part of the total production. Metal production recorded by the U.S. Bureau of Mines (Vanderburg, 1939, p. 21) together with more recent production is tabulated in table 5 .

\section{FUTURE OF THE DISTRICT}

The Battle Mountain district has been thoroughly prospected for more than 80 years. During the early days of the camp, the rich supergene silver ores in Galena Canyon and at the Little Giant mine in Copper Basin were important, but the principal production was from the copper-bearing veins in Copper Canyon. The silver ores were soon exhausted, and copper producers became the mainstays of the district through the 1940's. Emphasis shifted to zinc and lead during 1952-53, when the Hornfels ore body was being mined at the Copper Canyon mine. Improvements in transportation facilities and in metallurgy which have permitted utilization of low-grade base metal ores have resulted in nearly continuous operation of some properties.

The old prospectors who discovered most of Nevada's mineral deposits are fast passing on, and their ranks are not being filled. During the early boom days, the population of the town of Galena was said to have been several thousand; in 1955 the population was two men. Even as late as the 1930's, fifty or more men made their living by mining on small properties in the Battle Mountain district. In 1955 there were possibly 10 men in all, mainly lessees who were shipping copper ores from dumps in Copper Canyon and Copper Basin. The comparatively low prices of lead, zinc, and copper, together with high labor and transportation costs, have made it difficult for the small operator to make a living at mining.

The long-term outlook for continued production in the district is promising. Intelligently planned exporation should result in the discovery of new ore bodies. At higher metal prices or with metal subsidy payments, the Battle Mountain district should have a long productive future. ${ }^{2}$

\footnotetext{
${ }^{2}$ An oral communication from J. E. Frost, Duval Corp. (1964), states that recent exploration in the district has revealed substantial tonnages of low grade ore; studies are being carried on to determine whether the ore can be mined and processed at prevailing metal prices.
} 
TABLE 5.-Production of gold, silver, copper, lead, and zinc, Battle Mountain district, 1902-61

[Figures furnished by U.S. Bur. of Mines; published with permission of the owners]

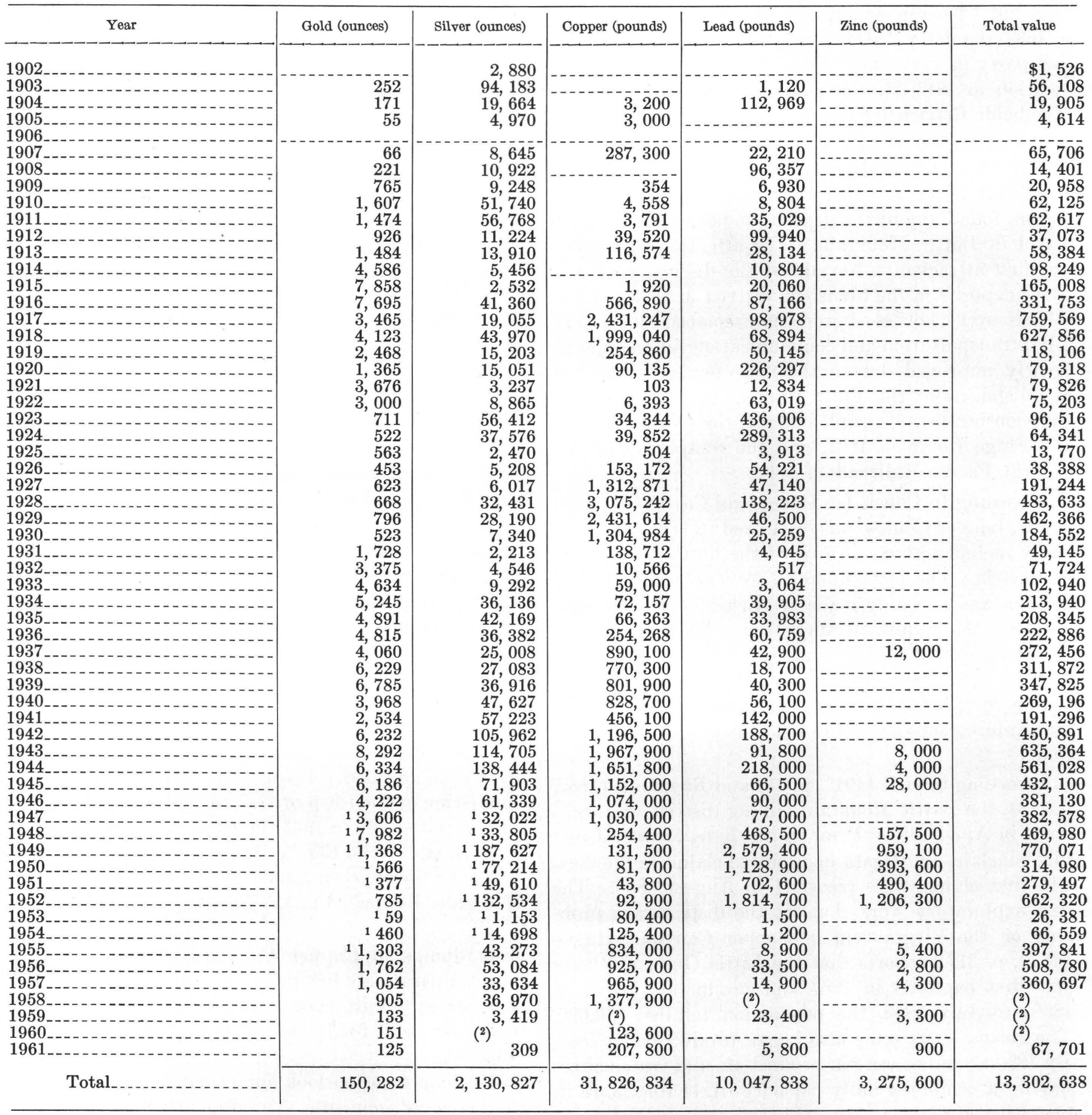

${ }_{2}^{1}$ Lode gold and silver only.

2 Figure withheld to avoid disclosing company confidential data.

\section{MINES}

LODE DEPOSITS

COPPER CANYON-IRON CANYON AREA

The Copper Canyon-Iron Canyon area in the southeastern part of Battle Mountain has been the most pro- ductive part of the Battle Mountain district (pl. 3). The area includes the Copper Canyon, Iron Canyon, Nevada, and Plumas mines which are peripherally arranged around the Copper Canyon stock.

The oldest rock in the area is the Scott Canyon For- 
mation which crops out in Butte, Iron, and Philadelphia Canyons. On the west, the Harmony Formation has been dropped down against the Scott Canyon Formation on steep faults; formerly the Harmony Formation in the upper plate of the Dewitt thrust covered all this area, but except for a few remnants, the upper plate has been largely eroded. On the ridge between Iron and Copper Canyons, the Battle Formation of Pennsylvanian age rests unconformably upon the Harmony Formation and dips westward; the dip steepens to vertical in Copper Canyon. In Copper Canyon the Battle and Harmony Formations are in contact with the Pumpernickel Formation, in part along normal faults and in part along a thrust fault. The quartz monzonite in Copper Canyon cuts the Pumpernickel, Battle, and Harmony Formations.

The ore deposits in the area are arranged peripherally around the quartz monzonite. They include contact metamorphic and replacement bodies along bedding and ore bodies along faults.

$$
\text { COPPER CANYON MINE }(9)^{3}
$$

History and production.-The Copper Canyon mine is 18 miles southwest of the town of Battle Mountain at the south end of Battle Mountain (pl. 5, fig. 16). The property consists of 19 patented lode claims, 17 unpatented lode claims, 3 unpatented placer claims, and 720 acres of patented agricultural land. In 1955 the property was equipped with a flotation mill of 350 tons daily capacity.

Copper showings were first located at Copper Canyon by Messrs. Tanehill, Sinclair, and Heath prior to 1866 ; the first claims recorded were the Lake Superior and Virgin claims (Hill, 1915, p. 71-72; Whitehill, 1873, p. 49). Exploratory work was started on the Virgin fault zone, and regular shipments began in 1870 when the property was taken over by the Battle Mountain Mining Co. The recorded shipments by this company through 1877 total 4,572 tons valued at $\$ 309,876$. The average grade of the ore is not known, but fragmentary reports indicate that the grade ranged from 20 to 30 percent copper. The ore was sacked and hauled to Sacramento, Calif., by oxen teams; it was then transported by barge to San Francisco and then by sailing vessels to Swansea, Wales. Prior to 1876 , part of this ore was selectively mined and hand sorted; during 1876 a concentrating plant of 30 tons daily capacity consisting of a crusher and hand-operated jigs was erected near the mouth of Willow Creek (Hill, 1915, p. 72).

In 1897 the Glasgow and Western Exploration Co. bought the property and began shipments of ore averaging about 11 percent copper to a smelter at Golconda,

\footnotetext{
${ }^{3}$ Numbers in parentheses refer to mine numbers on pl. 3.
}

Nev., where the ore was mixed with copper ore from the Adelaide district. The operation did not prove profitable at the prevailing price of copper, and the smelter was finally shut down in 1906 . In 1912 a leaching plant was constructed at Copper Canyon to treat the ore. As the ore available then contained mixed oxide, carbonate, and sulfide minerals, the leaching process was not suited to the ore, and the plant was closed.

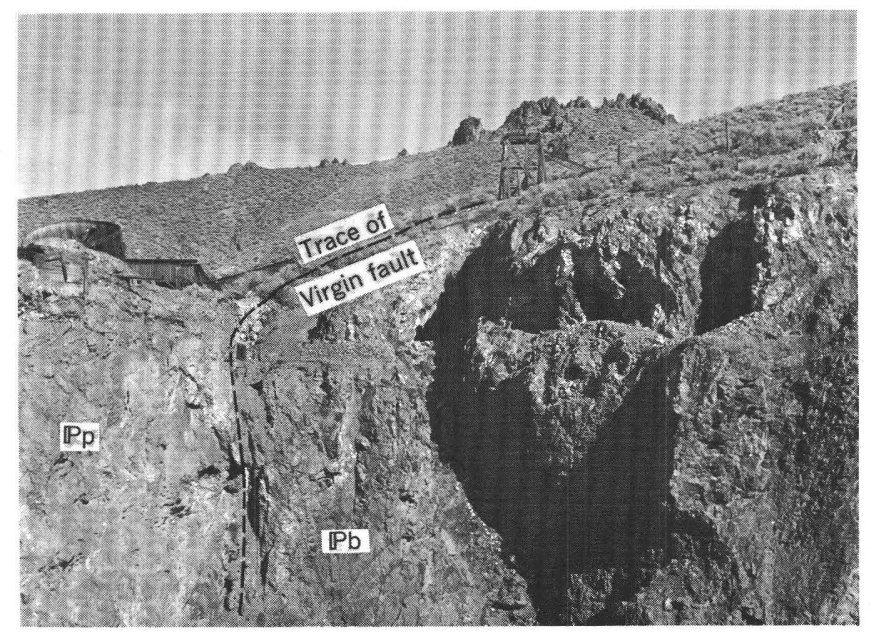

Figure 16.-Copper Canyon glory hole. Virgin fault zone on left; hanging-wallrock is Pumpernickel Formation $(\mathbb{P} p)$, footwall rock is hornfels of the Battle Formation ( $\mathbb{P b}$ ).

In April 1916 the Copper Canyon Mining Co. purchased the property from the Glasgow and Western Co. and renewed exploratory work. New copper ore bodies were discovered in the footwall of the Virgin vein. Between August 1916 and December 1918, 22,489 tons of ore averaging 9 percent copper, largely from above the 200 level, was shipped. In addition, 3,000 tons of tailings averaging 4.5 percent copper was shipped to a Utah smelter. Between 1919 and 1930 there was little activity in the camp except by lessees. In 1931 Robert Wigglesworth discovered gold-copper ore in the footwall of the Virgin vein at what is now the glory hole. In 1936 the Copper Canyon Co. began exploration of the gold-copper ore bodies and during succeeding years found a large tonnage from the surface down to the 300-foot level. In 1941 the property was leased to the International Smelting and Refining Co. of Salt Lake City, Utah, a subsidiary of the Anaconda Copper Mining Co., and a 350-ton mill was constructed on the property. A three-compartment vertical shaft was put down to mine the ore, and between 1941 and December $1945,312,694$ tons was milled.

On December 1, 1945, the International Smelting and Refining Co. relinquished their option, and the Copper Canyon Mining Co. resumed operations. Mining and 
milling continued through July 1947 when suspension of metal premiums made copper ore mining unprofitable. In late 1947, the company began sinking the Julie shaft to the 700 level to mine a lead-zinc-silver ore body which had been discovered by diamond drilling during 1942. The shaft was completed in January 1948, and a crosscut was driven to intersect the ore body about 600 feet north of the shaft. Milling of lead-zinc ore began in August 1948 and continued until a fire closed the mine in June 1950. Operations were resumed in 1951 and continued until October 1952, when a decrease in lead-zinc prices and an increase in costs made mining on the 700 level unprofitable.

In 1952 the Copper Canyon mill was modified to produce separate lead and zinc concentrates instead of a bulk lead-zinc concentrate product. Assays by the Copper Canyon Mining Co. staff of the zinc concentrate show the following ranges: 0.20 to 0.27 ounce of gold and 10.8 to 12.0 ounces of silver to the ton; zinc, 40.2 to 42.0 percent; lead, 2.2 to 3.0 percent; copper, 1.7 to 1.9 percent; iron, 14.5 to 15.1 percent; sulfur, 27.1 to 29.8 percent; arsenic, 0.2 percent; and antimony, 0.1 to 0.15 percent. Assays of the lead concentrates show the following ranges : 0.31 to 0.34 ounce of gold and 82.7 to 89.5 ounces of silver to the ton; 59.3 to 62.2 percent lead; 2.8 to 3.5 percent zinc; 2.4 to 2.7 percent copper; and 5.3 to 6.2 percent iron. (See table 6 .)

Operations continued intermittently during the next few years with a shutdown in 1953-54 caused by a fire in the Julie shaft and in the mill. The mill was finally

TABLE 6.-Production of gold, silver, copper, lead, and zinc, Copper Canyon mine 1871-1954

[Figures from 1897-1954 furnished by Copper Canyon Mining Co.; published with permission]

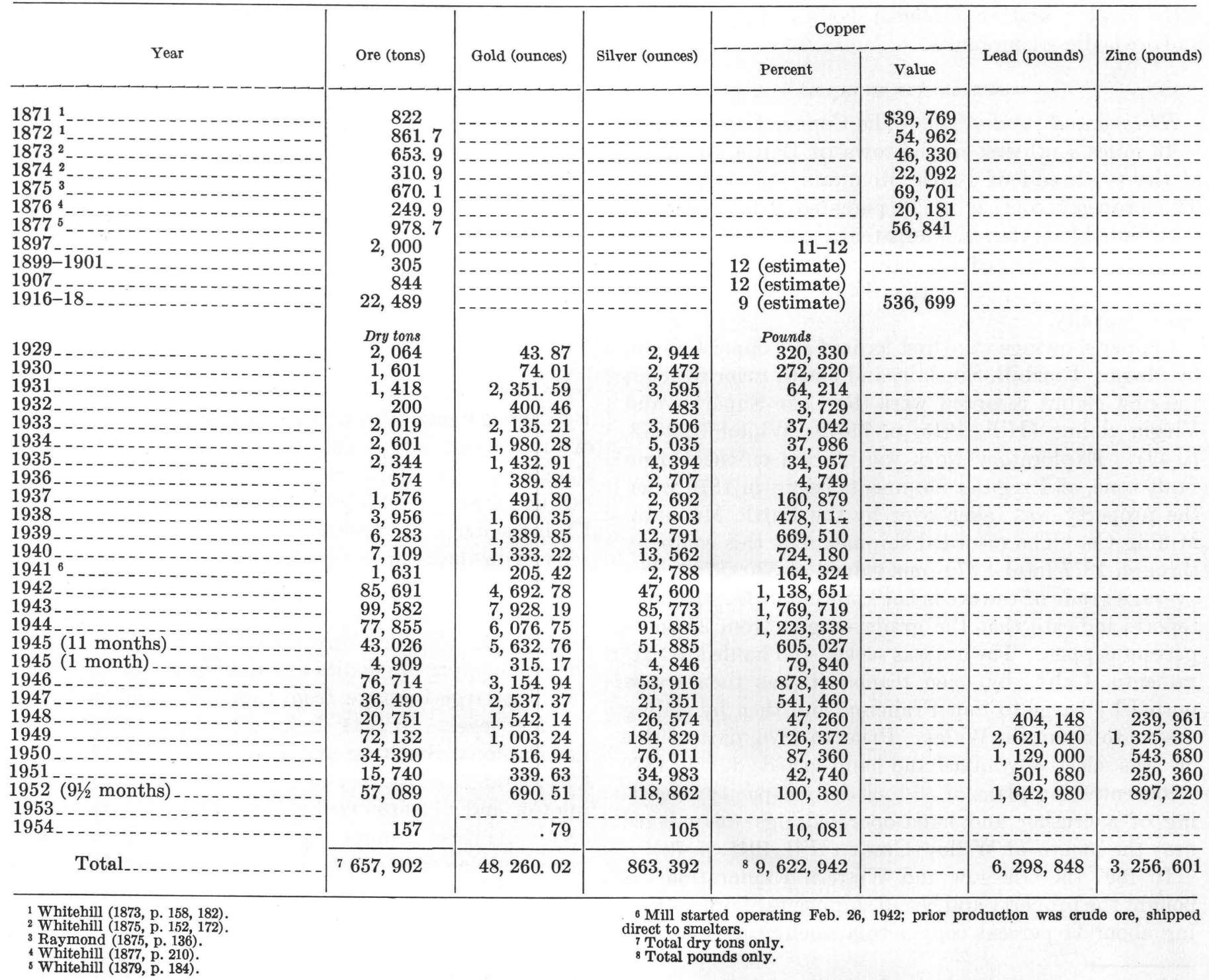


shut down in 1957 , but operations by lessees continued intermittently. In mid-1959 the property was taken over by the United States Government. It was sold later in the year to the American Smelting and Refining Co., which carried on exploratory drilling during the next 2 years north of the main workings. In 1961 the Duval Co. (formerly the Duval Sulfur and Potash Co.) continued the drilling program and also began exploration at Copper Basin.

The workings at Copper Canyon mine include two main shafts: the Julie, a vertical shaft 770 feet deep, and the Virgin, an inclined shaft 530 feet deep. Between these shafts is the glory hole (fig. 16), an open pit 140 by 300 feet, and numerous opencuts, pits, and shallow shafts. The underground workings are on six principal levels-the $100,200,260,300,500-530$ and 700 levels (pl. 6). The upper four levels were originally driven from the Virgin shaft. When the Julie shaft was put down in 1941 to mine copper-gold ore, a lower level, the 500, was driven, and in 1948 the 700 level was driven. The workings explore ore bodies along the Virgin, Estes, and Superior faults, and disseminated ore bodies in fractured ground adjacent to these faults and others.

Geology.-The Copper Canyon mine area is astride three of the major structural blocks that make up Battle Mountain (pls. 2 and 7). The western part of the mine area is underlain by the Pumpernickel Formation of the Golconda block. The eastern part is underlain by the Harmony Formation of the Dewitt block and the Battle Formation of the Antler block. Quartz monzonite, in a stock at the north end of the mine area and also in dikes, cuts across all three blocks.

The western part of the mine area, which is underlain by the Pumpernickel Formation, is separated from the eastern part by the Virgin fault (fig. 16). The Pumpernickel Formation forms the hanging-wall side of the fault as far down as the 260 level at the Virgin shaft. Below this level, the hanging-wall rock is Battle Formation.

The footwall block of the Virgin fault is composed of complexly faulted segments of the Harmony and Battle Formations. The Harmony Formation is made up of interbedded biotite hornfels and quartzite which are complexly folded and metamorphosed and are overlain unconformably by the Battle Formation. In the mapping of the underground workings, the Battle Formation has been subdivided into three units: a lower calcareous (now chloritic) conglomerate, a middle hornfels, and an upper quartzite conglomerate. These units are not strictly correlative with the members of the formation at the type locality (p. B8) because of lateral variation along the strike. Broadly speaking, the same 736-007 O-65-4 units are recognizable in the two areas, with the exception that the middle hornfels and upper quartzitic conglomerate units are less distinct at the type locality. In the mine workings, the lower conglomerate is 80 to 120 feet thick, the middle hornfels about 150 feet thick, and the upper quartzite is more than 300 feet thick.

The Virgin fault is a north-trending normal fault that dips $50^{\circ}$ to $65^{\circ} \mathrm{W}$. in the mine area. The fault has a vertical displacement of about 1,000 feet; on the upper levels it separates chert and quartzite of the Pumpernickel Formation on the hanging wall from hornfels and quartzitic conglomerate of the Battle Formation in the footwall, but on the lower levels the hanging-wall rock is also hornfels and quartzitic conglomerate of the Battle Formation. The contact between the Pumpernickel and Battle, which lies between the 200 level and the 260 level, is probably the Golconda thrust fault. Drill holes west of the Virgin fault first penetrated quartzite and chert of the Pumpernickel and at depth passed into quartzite and hornfels of the Battle Formation.

The Hayden fault and a split called the Gulch fault bound the workings on the east. The Hayden fault, which strikes northward and dips about $70^{\circ}$ west, was not intersected in the upper workings, but at the bottom of the Julie shaft a shear zone believed to be in the hanging wall of the Hayden fault is exposed. The Gulch fault strikes northeastward and dips $60^{\circ}$ to $65^{\circ} \mathrm{NW}$; it joins the Hayden fault about 500 feet north of the workings and the Virgin fault south of the workings. The Gulch fault appears to have formed in response to stresses, possibly tangential in nature, set up between the Virgin and Hayden faults. The displacement along the Gulch fault is not known.

Two other faults, the Estes and Superior faults (pl. $8 A$ ), were the loci of enriched copper ore bodies which yielded much of the chalcocite ore stoped on the upper levels. The Estes fault strikes northwestward and dips steeply northeastward on the upper levels but flattens to $35^{\circ}$ on the 500 level. The Superior fault strikes N. $30^{\circ} \mathrm{E}$. and dips $55^{\circ}$ to $70^{\circ}$ northwestward. The Superior fault parallels the Virgin and Hayden faults and was presumably formed at the same time. The Estes fault intersects the Superior fault in the workings; on the 200 level the Estes fault appears to displace the Superior fault a few feet; this displacement may be due to renewed movement on the Estes fault which is thought to be older.

The West fault is another northwest-trending fault, well exposed on the 500 level and extending upward into the 300 level workings where it is intersected by other faults. The West fault extends below the 500 level; just above the 700 level it forms the northwest boundary of 
the Hornfels ore body. As the West fault contains primary sulfides including pyrite, galena, sphalerite, and chalcopyrite, it may well have been a channel for primary mineralizing solutions and probably played a part in the formation of the Hornfels ore body.

Ore deposits.-The ore bodies which have been mined can be separated into three main groups: primary, enriched, and oxide ore bodies. The primary bodies have yielded the major production to date, but during the early days the oxide, and later, the enriched bodies were more important.

The primary ore bodies may be subdivided into two sub-types, copper-gold bodies and lead-zinc bodies. The copper-gold bodies contain pyrite, pyrrhotite, arsenopyrite, sphalerite, chalcopyrite, and galena (fig. 11A$D)$. Siderite, calcite, and quartz are the associated gangue minerals in a host rock of chloritic or quartzitic conglomerate. The lead-zinc bodies contain pyrite, sphalerite, galena, and chalcopyrite (figs. 9, 10A). Siderite, calcite, quartz, and barite are the associated gangue minerals in a host rock of hornfels, porcellanite, and conglomerate. Typical specimens of the primary ore are intensely brecciated and contain fillings of the sulfide and gangue minerals along the borders of rock fragments (figs. 9, 10). The ore minerals were introduced into host rocks that had been metamorphosed during intrusion of the quartz monzonite. As the temperature fell during mineralization, the earlier lime and magnesian silicate minerals became unstable and were altered to chlorite and clay minerals. The lead-zinc ores are conspicuously chloritized and in places are quite soft. The quartzitic conglomerate was little changed during mineralization in both the lead-zinc and coppergold ore bodies.

The enriched copper ore bodies that have been mined were mainly above the 300 level. The enriched ore consisted of the primary sulfide minerals of the copper-gold ore plus secondary chalcocite and a little native copper (fig. 12A). The chalcocite either partly or wholly replaced pyrite, pyrrhotite, or arsenopyrite; the grade of the enriched ore shipped averaged about 10 percent copper which is nearly a fivefold increase over the copper content of the primary ore. Presumably, the ore was selectively mined to maintain a 10 percent grade. The enriched copper ore characteristically contains little gold and silver, as these metals apparently did not migrate with the copper.

The oxidized ore bodies were mainly above the 200 level, although oxidation locally extends deeper. The oxidized ores consist of malachite and a little azurite, cuprite, and chrysocolla. Efflorescences of magnesium, copper, and iron sulfates coat cavities in the rock and the walls of the workings. In general, the wallrocks of the oxidized zone are highly leached, argillized, and stained with iron oxides. Jarosite is a common constituent in places. The copper content of the oxidized zone is generally not high, except where the cuprite content is high. As the cuprite was formed originally from secondary chalcocite (fig. $12 \mathrm{~A}$ ), it is evident that highgrade cuprite ore can be formed only from high-grade enriched ore. The gold content of the oxidized ore is highly variable; some of the ore mined from opencuts east of the Virgin shaft contained more than an ounce of gold to the ton.

The ore bodies in the Copper Canyon mine occur in three structural settings: (1) tabular ore bodies along faults, (2) lenticular or irregularly shaped ore bodies in crushed zones between faults, and (3) tabular ore bodies that follow bedding. The ore bodies belonging to the first group include the Virgin, Estes, and Superior veins. The second group is represented by the Hornfels and West ore bodies. The third group is typified by the North ore body.

The ore bodies on the Virgin fault were distributed along the fault for a strike length of about 300 feet. In places the ore was 20 feet or more wide, but it averaged considerably less, probably not more than 5 feet. The ore bodies extended from the surface downward to the 470 level, although most of the stoping was done above the 300 level. The ore shoots show a pronounced pitch to the north (fig. 18). The reason for this is not certain, but it is interesting to note that the projection of the trace of the intersection of the West fault with the Virgin fault roughly coincides with the lower edge of the stopes. The ore shoots mined above the 100 level (pl. $8 A$ ) on the Virgin fault were composed mainly of chalcocite partially altered to cuprite and malachite; below the 100 level chalcocite was predominant. These stopes furnished most of the ore shipped in the 1870's which was hand sorted to a grade of 25 to 30 percent copper.

The Superior vein (pl. $8 B$ ) was also worked during the 1870's and yielded chalcocite ore from a shoot 100 feet long and a foot to 20 feet wide. The principal stope was in the northern part of the workings, but it extended down only to the 100 level. Low-grade copper ore continues downward, but the secondary chalcocite which characterized the rich ore above is missing.

The Estes vein in the footwall of the Virgin fault was known during the early days, but commercial ore was not discovered within it until 1916. The ore shipped between 1916 and 1918 averaged 9 to 10 percent copper after sorting. The ore body was 110 feet long, 12 to 30 feet wide, and was mined to the 200 level. Part of the stope fill left after sorting was milled by the Copper Canyon Mining Co. in 1946 and 1947; the ore milled 


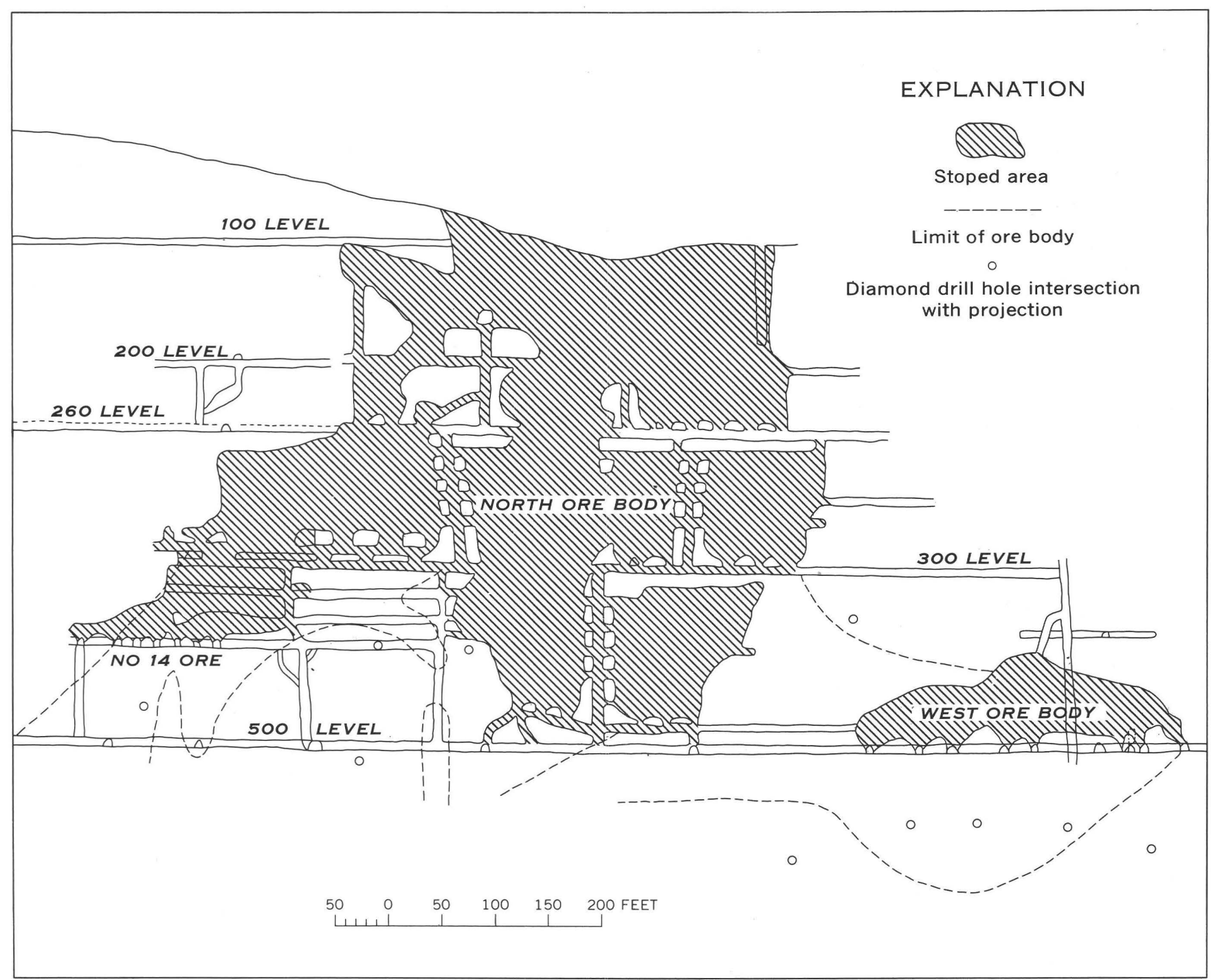

From Copper Canyon Mining Co. maps, 1952.

Published with permission

Figure 17.-Crescentic longitudinal projection showing stopes in the Copper Canyon mine.

amounted to 22,000 tons averaging 2.60 percent copper. North ore body.-The North ore body was stoped from its south border at the Gulch fault northward nearly 400 feet and yielded about 250,000 tons of ore averaging 1 percent copper, 1.5 ounces of silver, and 0.1 ounce of gold (fig. 17). The ore body was as much as 60 feet wide at the south end, but it narrowed gradually northward. South of the Gulch fault the contact of the Harmony and basal conglomerate of the Battle Formation has not been explored and is a possible locus for ore, even though the contact on the 300 level above showed only low-grade metallized rock (pl. 9A).

West ore body.-The West ore body extending northwestward from the haulage crosscut on the 500 level was stoped upward to the 200 level $(\mathrm{pl} .8 C$ ). The ore extends downward about 100 feet below the 500 level, where it narrows and finally pinches out. The West ore body yielded 50,000 tons of ore of lower tenor in copper but higher in gold than the North ore body; the West ore body averaged 0.5 percent copper and 0.25 ounce of gold to the ton.

Hornfels ore body.-The Hornfels lead-zinc-silver ore body between the 500 and 700 levels (pl. $9 D$ ) was discovered by drilling during 1942 and was subsequently blocked out by other drill holes. The ore body lies between the Gulch and West faults and appears to pitch northward. The full extent of the ore is not yet known, but it is localized in brecciated hornfels just above the lower conglomerate member of the Battle Formation. Therefore, the localization of the ore seems to be in part controlled by lithology and in part by structure. The mineralizing solutions apparently trav- 
elled along the West fault and parallel faults and replaced the first favorable unit, the highly brecciated hornfels. The rock below the West fault, as indicated by drill holes, is apparently quartzite which normally overlies the hornfels; the West fault may be a reverse fault. The indicated reserves of the Hornfels ore body in 1955 totaled about 60,000 tons of ore averaging 2 percent lead and 1 percent zinc.

Superior adit.-The Superior adit was one of the working levels developed during the 1870's (pl. $8 B$ ). The adit follows the Superior fault from the glory hole northward to its intersection with the Virgin fault. The Superior fault on this level strikes north and dips $55^{\circ}$ to $75^{\circ} \mathrm{W}$. The fault zone is from 4 to 6 feet wide and consists of sheared hornfels of the middle unit of the Battle Formation. The sheared zone contains pyrite, pyrrhotite, arsenopyrite, sphalerite, iron oxides, and occasional pods of chalcocite, cuprite, and locally copper carbonates. Most of the ore mined from the Superior fault came from stopes above this level and is said to have been high in secondary chalcocite and cuprite.

The Virgin shaft collar is approximately the same level as the Superior adit. The wallrock on both sides of the Virgin fault at the collar is highly leached and altered. The fault contains cuprite and chalcocite lenses where it enters the glory hole, but elsewhere at this level it contains only sparse pockets of iron oxides.

Farren adit.-The Farren adit was driven from the floor of Copper Canyon N. $65^{\circ}$ E. for a distance of about 1,300 feet. It is in quartz monzonite from the portal for 210 feet and then is mainly in biotite hornfels of the Pumpernickel Formation for the next 480 feet. Evidently in this part of the adit, the Golconda thrust fault lies below the adit level. After crossing a fault that strikes N. $10^{\circ} \mathrm{W}$. and dips $72^{\circ} \mathrm{NE}$, at 690 feet, the wall rock is hornfels of the Battle Formation in the lower plate of the Golconda thrust (pl. 7). At a point 1,050 feet from the portal, the adit cuts the Virgin fault, which here separates hornfels of the middle unit of the Battle Formation and quartzite of the upper unit. No ore bodies were found in the fault here or in the drift that extends for 240 feet to the south along the fault. The last 50 feet of the adit is in quartz monzonite. From surface expression, the contact of the quartz monzonite is inferred to swing westward possibly within 200 feet of where it is intersected.

100 level.-The 100 level workings (pl. $8 B$ ) were originally driven from the Virgin shaft to explore the Virgin, Estes, and Superior fault zones. The workings are mainly in the middle and lower units of the Battle Formation. In this area metamorphism and alteration have obscured details of bedding in most places, but about 100 feet east of the Virgin shaft the beds strike N. $60^{\circ}$ W. and dip $30^{\circ} \mathrm{SW}$. A dike of quartz monzonite porphyry cuts the conglomerate in the footwall of the Superior fault at the south end of the workings.

The Virgin fault was not productive on the 100 level south of the shaft, but to the north mining was extended down into the Submarine stope (pl. $8 B$ and fig. 18). The ore body mined from this stope was localized where fractures parallel to the Estes fault intersected the Virgin fault. The ore mined from the Submarine and Estes stopes consisted mainly of chalcocite. The Estes fault dips steeply northeastward on the 100 level; it is cut off on the southeast by the Superior fault and on the northeast by the Virgin fault. The Estes fault therefore appears to belong to an older fault set. On the lower levels the dip flattens to $30^{\circ}$ to $40^{\circ} \mathrm{NE}$. The Superior fault did not yield much ore on the 100 level, but it was stoped upward nearly to the surface in the northern part of the workings. Southward the strike of the fault swings to northeast-southwest.

The workings in the lower conglomerate explore goldcopper ore bodies discovered there during the 1930's. Much of this area was engulfed in the glory hole following mining operations carried on during the late 1930's and 1940's.

200 level.-These workings are mainly in hornfels of the middle unit of the Battle Formation and conglomerate of the lower unit $(\mathrm{pl} .8 \mathrm{C})$. These rocks strike northeastward and dip steeply northwestward in the southern part of the workings. From drill-hole data it is known that the contact bends gradually to the north and may even strike a little west of north at the north end of the workings. This trend is also noted on the crosscut between the Estes and Superior veins where the beds strike N. $30^{\circ}$ to $65^{\circ} \mathrm{W}$. and dip $40^{\circ}$ to $60^{\circ}$ SW. The quartz monzonite porphyry dike cut on the 100 level was also cut on the 200 level.

The Estes vein has been explored on this level but contains only pyrite and possibly arsenopyrite and sparse pods of chalcocite and cuprite. Stoping along the Estes vein began about 20 feet above the level and extended up to the 100 level, widening upward. The southern part of the workings. From drill-hole data Superior vein also was explored on the level, but it contained only small pockets of sulfides and iron oxides.

The contact of the lower unit of the Battle Formation with the underlying Harmony Formation is exposed in the crosscut into the footwall of the Gulch fault. The lower unit is well mineralized adjacent to the fault along the area explored in the drift, and has been stoped above and below the level (pls. $8 C, 10$, section $\left.C-C^{\prime}\right)$. 


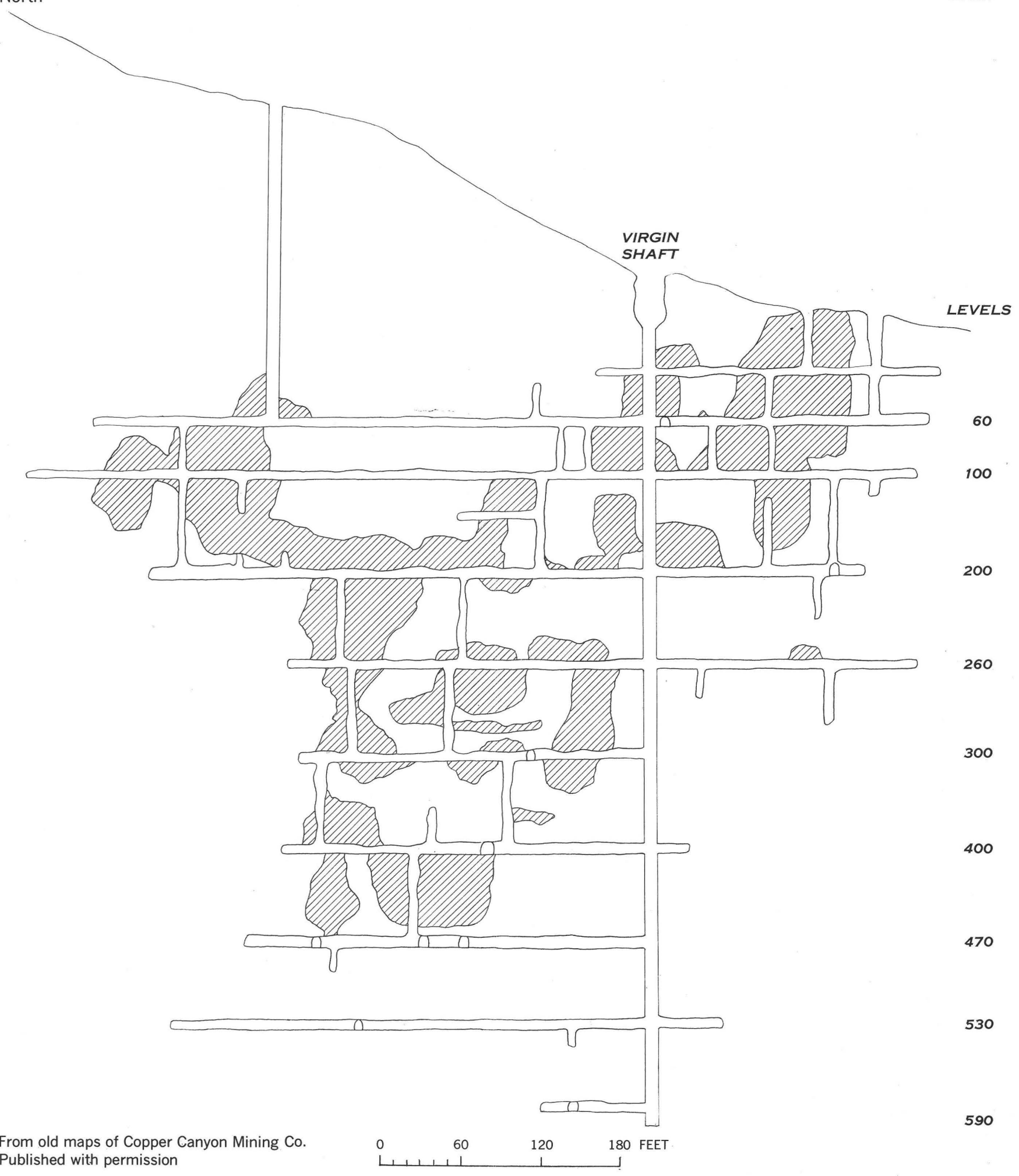

FIGURE 18.-Longitudinal section in plane of the Virgin vein, Copper Canyon mine. 
260 level.-The 260 level workings are in the same formations as the 200 level, except that the hangingwall rock of the Virgin fault on the 260 level is hornfels of the Battle Formation ( $\mathrm{pl} .8 D$ ). The Golconda thrust, therefore, was crossed by the Virgin shaft between the 200 and 260 levels; because of lagging in the shaft, the actual thrust contact cannot be seen. Robert Raring, mine manager, reported that in a raise at coordinates $10,070 \mathrm{~N}$. and 9,850 E. high-grade gold assays were noted in samples cut for 20 feet up the raise, and that the rock changed about 30 feet up to siliceous hornfels. These high-gold assays may have come from mineralized rock along the sheared zone formed during thrust faulting.

On the 260 level the main stopes on the Virgin fault were north of the Virgin shaft (pl. $8 D)$. Neither the Estes nor Superior faults were stoped on the 260 level, although both of them contain pockets of primary and secondary sulfides.

300 level.-The 300 level workings explore the same formations as the 260 level (pl. $9 B$ ). Stopes on the Virgin fault on the 300 level extended about 240 feet north of the shaft, and in places they were 5 to 15 feet wide.

Neither the Superior nor Estes fault zones were explored to any extent on the 300 level (pl. 9B). The stope outline on the $300-1$ sublevel (altitude 5,498) shows that the North ore body ranged from 10 to 70 feet wide and was stoped for about 300 feet northward from the Gulch fault. From the projection of the 300-1 sublevel on the 300 level the east limit of the North ore body appears to extend over into the Harmony Formation, but actually the east limit of the stope was the basal contact of the lower unit of the Battle Formation. The contact is a sedimentary contact for the most part but is locally sheared. Even though both formations are more or less equally sheared and brecciated, it is noteworthy that the metallization is confined to the chloritic conglomerate of the Battle Formation.

500 level.-The 500 level was driven as a working level for stoping the downward extensions of the North and West ore bodies (pl. 9C). The geologic formations and structures are the same as on the 300 level with the exception that the basal contact of the Battle Formation is locally overturned and dips steeply eastward. Drill hole data suggest that the overturning is even more pronounced below the 500 level (pl. 10, section $B-B^{\prime}$ ).

The Virgin fault was not explored on the 500 level, but a drift was driven along it on the 530 level from the Virgin shaft in the 1870 's. Small pockets and veinlets of primary sulfides occur in the fault zone, but no stoping has been attempted. Sulfide minerals are sparsely scattered along the 530 level crosscut.
The section along line $B-B^{\prime}$ shows the main structural features of the mine (pl. 10). Near the surface the lower member of the Battle Formation dips gently, but it abruptly steepens and continues downward nearly vertical to the 500 level, then overturns below the level. The relationship of the Estes, Superior, and Virgin faults is well shown in this section. No ore was mined in the lower conglomerate unit this far north.

The section along line $A-A^{\prime}$ (pl. 10) shows the complex faulting along the footwall of the North ore body and the relationship of the Hornfels ore body to major faults. The lower conglomerate member has been cut out by the Gulch fault zone below the 500 level.

The section along $C-C^{\prime}$ (pl. 10) illustrates the abrupt steepening of the lower member of the Battle Formation from the surface downward into the glory hole. The North ore body as shown on section $C-C^{\prime}$ closely parallels the sheared contact. The stopes were developed only in the Battle Formation and nowhere extend into the Harmony Formation. Secondary copper bodies were mined downward to the 100 level on the Superior fault.

The section along line $B-B^{\prime}$ (pl. 10) clearly shows the overturning of the beds near the 500 levei. Diamond drill holes were drilled mainly to outline the Hornfels ore body, but they also show that the upper quartzitic conglomerate of the Battle Formation underlies the West fault, which is nearly parallel to the section.

In the section through $C-C^{\prime}$ (pl. 10), the relationship of the North gold-copper ore bodies to the lower conglomerate is well shown. The ore bodies are along the base of the unit, and in many places stoping extended to the contact. The ore bodies appeared to follow shear zones parallel to the main shear on the contact. Throughout this part of the mine the dip is uniformly steep. The stopes on the Estes and Superior faults are cut also by this section.

In the section along $D-D^{\prime}$, the Virgin fault is well shown (pl. 10). Stopes extended nearly all the way to the 500 level along the fault. The stopes above the 100 level on the Estes fault are reported to have yielded rich secondary copper ore, and, together with the stopes on the Virgin and Superior faults, accounted for the bulk of the ore mined in the early days.

700 level.-The 700 level was driven from the Virgin shaft to extract the Hornfels ore body between the 500 and 700 levels (pl. 9D). The 700 level is mostly in the lower and middle members of the Battle Formation, which here appear to be nearly vertical; a short distance above the level the dip flattens locally. The lower member contained gold-copper ore between the 500 and 700 levels, but the grade was too low to warrant stoping 
of this material. The lead-zinc ore was mainly in brecciated hornfels of the middle member, which was stoped over a maximum width of 170 feet and strike length of 350 feet. The West fault formed the footwall of the ore in the southwestern part of the level.

$$
\text { IRON CANYON MINE (17) }
$$

The Iron Canyon mine is in Iron Canyon in the W1/2 sec. 23, T. 31 N., R. 43 E. The property consists of nine patented claims owned by the San Miguel Nevada Mines, Ltd., of Detroit, Michigan. In 1953 the property was under option to H. B. Chessher of Reno, Nevada.

The Iron Canyon mine has been intermittently productive since 1908. The first shipments were relatively high in gold; much of the oxidized ore yielded more than two ounces to the ton. The available production data follows:

Production of gold, silver, copper, and lead, Iron Canyon mine, 1908-41

[Furnished by H. B. Chessher; published with his permission]

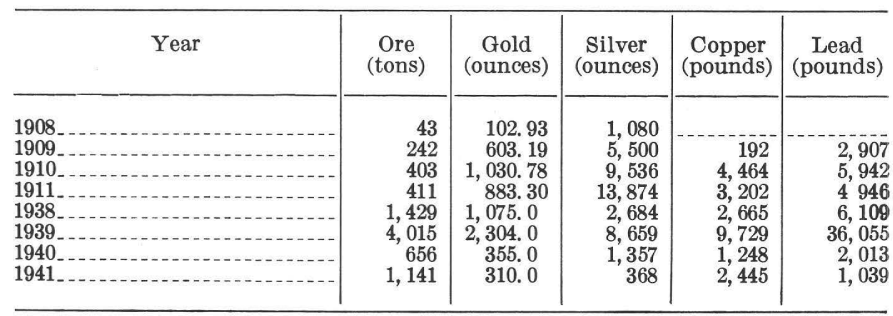

The primary ore in the Iron Canyon mine is composed of pyrite, pyrrhotite, arsenopyrite, and pockets of sphalerite, galena, and a little chalcopyrite that replace a shale-chert layer and form veins along fault zones. The replacement bodies are as much as 20 feet thick and 150 feet long. Locally they are composed of massive sulfides (fig. $10 B$ ), but generally the sulfides are intercalated with unreplaced shaly and cherty layers and with a few calc-silicate layers. Near the surface the sulfide minerals are oxidized; the iron-bearing minerals altered to iron oxides which contain pockets of secondary zinc and lead minerals, especially calamine and cerussite. Shipments of ore from the oxidized zone since 1939 have averaged less than 1 percent each of lead and zinc; copper averaged less than 0.2 percent; arsenic ranged from a trace to 3.3 percent; antimony was as high as 0.4 percent. The gold content ranged from 0.25 to 1.8 ounces and silver from 0.55 to 5.7 ounces per ton. Some sulfide ore was shipped, but it is reported that the gold tenor was generally less than 0.15 ounce per ton.

The principal workings are on the Iron Canyon, Compromise, and Planet claims (pl. 11). These workings are mainly along the Wing fault which strikes north and dips steeply westward. The country rock is chert, shale, limy shale, limestone, and greenstone of the Scott Canyon Formation. In most of the workings the bedding strikes nearly parallel to the strike of the Wing fault, but dips westward less steeply. The limy shale and limestone have been, in part, converted into calcsilicate rock; although there are no intrusive rocks mapped in the mine area, it is inferred that intrusive bodies occur nearby.

The Cave adit, which is on the south side of Iron Canyon at the canyon bottom, is in the hanging wall of the Wing fault. The ore body that has been mined from this adit is in part along the fault and in part replaces a limy shale unit. The portal is in massive to porous iron oxides that grade into sulfide ore about a hundred feet south of the portal. The adit splits into two branches about 160 feet from the portal. The west branch goes into two connected caves that are believed to be solution caves in a limestone unit just above the sulfide-bearing unit (Young, 1915, p. 190). The caves are coated with iron oxides, gypsum, and calcite, and at a few places on their peripheries pockets of sulfide minerals can be seen. The bottom is covered with rubble of iron oxides and iron sulfate into which a shaft 25 feet deep has been sunk. The east adit branch continues to follow the ore layer, which is composed mainly of massive pyrite and pyrrhotite and also contains pockets of sphalerite, galena, and a little chalcopyrite. The stopes above the adit level are mainly in oxidized ore that was mined to the surface.

The G \& $\mathrm{C}$ workings are also mainly in the hanging wall of the Wing fault. The workings consist of an inclined shaft 115 feet deep and a connecting adit at an altitude of 5,800 feet. Oxide ore was stoped along shear zones cut in the workings, but stoping was not extensive.

The Iron Canyon adit and connecting workings are mainly in the footwall of the Wing fault which here closely parallels the strike and dip of the ore layer. Except for a few kernels of sulfides, the ore mined in the Iron Canyon workings was oxide ore composed of porous iron oxides containing gold. The ore layer is 12 to 15 feet thick and dips westward about $35^{\circ}$ near the surface but steepens to $45^{\circ}$ below the adit level. The oxidized ore extends to the lower level, gradually giving way to sulfide ore below.

The workings on the Compromise claim are in the footwall of the Wing fault and explore oxidized ore bodies along shear zones. A little ore was stoped along a northeastward-trending zone in argillized shale and chert.

The North Wedge adit is in chert and shale that have been cut by quartz monzonite porphyry dikes near the portal. Stopes extend to the surface along a sheared zone that strikes northeast and dips $40^{\circ}$ to $45^{\circ} \mathrm{NW}$., about 60 feet from the portal. 
The Planet workings on the Planet claim were driven along sheared zones that follow bedding in chert and shale. Iron oxide pockets and layers occur along the sheared zones; as no ore has been stoped, it is inferred that the material was too low grade for shipment. A little pyrite, sphalerite, and chalcopyrite was noted in the crosscut 240 feet from the portal of the No. 1 adit.

\section{NEVADA MINE (22)}

History and production.-The Nevada mine property is near the head of Copper Canyon in secs. 16 and 21, T. 31 N., R. 43 E. at an altitude of about 6,375 feet. The property consists of eight patented claims: the May Day, Robert Reich, Gilt Edge, Stella May, Marion, Walter Earl, October, Weimer Burr, and two unpatented claims, the December and Aorta. The group, which is owned by J. A. Hogle, Salt Lake City, Utah, adjoins the Copper Canyon property on the south, the Chessher properties on the east, and Langwith properties on the north.

The date of the discovery is not known, but the Nevada Mining Co. was organized at Salt Lake City in 1898. The first recorded production of the Nevada mine was in 1902 when 75 tons of ore assaying 38.4 ounces of silver to the ton was shipped. The principal production was was in the 1920's; shipments made in the 1940's were mostly from the dumps resulting from the early development work. The ore shipped has been lead-silver-gold ore containing a little zinc and copper. The production figures are as follows :

Production of gold, silver, copper, lead, and zinc, Nevada mine, 1902-48

[Furnished by the U.S. Bur. of Mines and H. B. Chessher; published with permission]

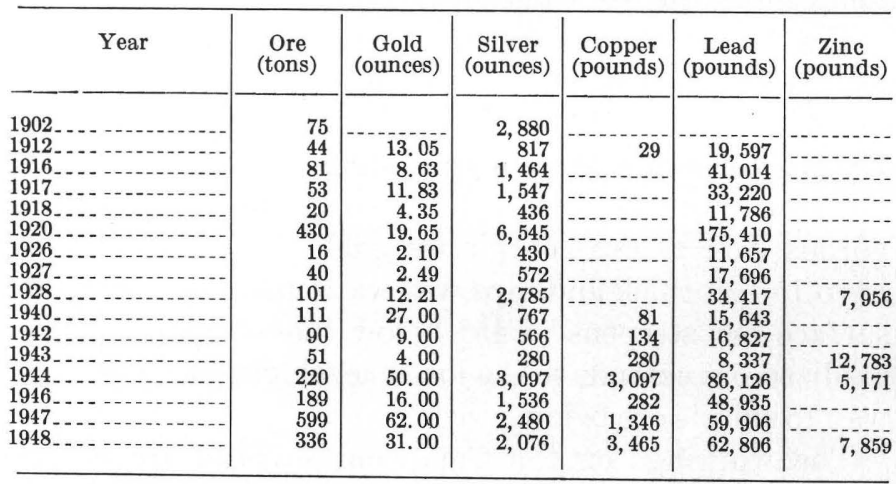

The workings of the Nevada mine are principally on the Marion and Stella May claims and total 3,565 feet of drifts and crosscuts connected by 200 feet of raises and winzes (pl. 12). A 250-foot vertical shaft and a 215-foot inclined shaft afford access to the mine workings. Development of the property is on two main levels which are 136 feet and 166 feet below the collar of the vertical shaft; and three sub-levels at 60 feet,
161 feet, and 183 feet below the collar of the vertical shaft. As water was within 160 feet of the collar of the vertical shaft at the time the property was examined the mine workings below the 136 level were inaccessible. The workings were mapped when the mine was in operation during World War II, however, and the base maps were made available by J. A. Hogle to the U.S. Geological Survey (pl.12).

Geology and ore deposits.-In the mine area, the rocks consist of conglomerate, chert, and shale of the Pumpernickel Formation, conglomerate and sandy limestone of the Edna Mountain Formation, limestone of the Antler Peak and sandstone and shale of the Harmony Formation. A quartz monzonite dike that intrudes these rocks was mapped in the workings.

At the surface the Pumpernickel Formation, which forms the upper plate of the Golconda thrust, underlies much of the mine area; on the west, it is faulted down on the Virgin fault against the Battle Formation; on the north and east, it has been stripped off, exposing the underlying Antler Peak Limestone and Edna Mountain Formation (pl. 3).

In the underground workings, the geologic picture has been obscured by complex faulting, but the following points seem clear. The eastern side of the workings are in sandstone and shale of the Harmony Formation which are sparsely mineralized. The contact of these rocks with the Antler Peak Limestone along the Virgin fault is complicated by a quartz monzonite porphyry dike; no ore has been stoped along the fault where it was explored along the East drift, and no sulfide metallization was noted. Antler Peak Limestone and limestone that is probably part of the Edna Mountain Formation are exposed along the crosscut westward to the Middle drift. The Middle drift follows the Middle fault, and the downthrown side is on the west; this fault dips steeply westward for the most part. On the hanging wall side of the Middle fault, black chert and shale of the Pumpernickel Formation make up the block extending westward to the West drift. A little ore has been stoped near the intersection of the Middle fault with the Northwest fault on shears that dip westward and are parallel to the Middle fault. The ore was stoped upward for as much as 15 feet.

The principal ore shoots that have been mined were in the block west of the West drift in limestone and conglomerate of the Edna Mountain Formation just below the Golconda thrust fault. The thrust fault is exposed in the workings at the south end of the West drift and in the inclined shaft about 90 feet down below the surface. The position of the thrust fault above and below the inclined shaft is uncertain, but it apparently strikes N. $15^{\circ}$ to $25^{\circ} \mathrm{W}$. and dips $30^{\circ}$ to $50^{\circ} \mathrm{SW}$. Metallization below the thrust was controlled by fracturing and 
by the favorable limy beds in the Edna Mountain Formation. Faulted segments of the ore may be present in the blocks east of the West drift and north of the Northwest fault below the Golconda thrust fault.

The primary ore minerals recognized in the workings are galena, sphalerite, pyrite, and specular hematite. Near the surface the galena has been oxidized to cerussite (sand carbonate) and anglesite, the sphalerite to smithsonite and hydrozincite, and the pyrite to hematite and limonite. Hill (1915, p. 89) also reports a soft black mineral at the water table that he considered to be argentite. Most of the ore shipped was composed of mixtures of the oxide minerals, but several tons of ore consisting of nearly pure galena are reported to have assayed 0.07 ounce gold, 48.8 ounces silver, and 53 percent lead. Two cars aggregating 44 tons that were shipped in 1912 gave the following smelter returns:

\begin{tabular}{|c|c|c|}
\hline & 1 & 2 \\
\hline Gold & 0.52 & 0.175 \\
\hline Silver _... & 14. 4 & 20. 6 \\
\hline percent__ & 15. 8 & 24. 8 \\
\hline . & 20. 3 & 20. 8 \\
\hline llfur & 4. 5 & 28. 8 \\
\hline$\ldots$ & 4. 8 & 17. 0 \\
\hline
\end{tabular}

The old stopes that yielded most of the production were caved and only partly accessible in 1952 when the mine was mapped. The ore bodies appear to have replaced favorable units in the Edna Mountain limestone and conglomerate.

WILSON-INDEPENDENCE MINE (6)

The Wilson-Independence mine is on the west side of the ridge west of Copper Canyon in the $\mathrm{SW}^{1} 1 / 4$ sec. 28, T. 31 N., R. 43 E. (pl. 12). The workings include an inclined shaft having an average dip of about $50^{\circ}$ and level workings that aggregated about 750 feet in 1955 . The property is owned by Dudley Wilson and Charles Crawford of Battle Mountain. The available production figures are as follows:

Production of gold and silver, Wilson-Independence mine, [Published with permission of the owners]

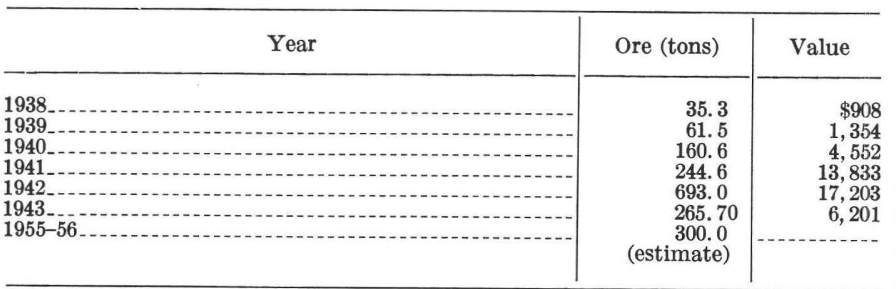

The ore bodies are in north-striking shear zones along bedding of the Pumpernickel Formation. The ore minerals are mainly cerargyrite and gold in a gangue of red and yellow oxidized minerals including limonite, jaro- site, and scorodite (iron arsenate). The ore contains many small quartz crystals and chert fragments. The ore bodies range from a few inches to 15 feet wide and mostly consist of loosely coherent material filling shear zones or caves. Originally the ore bodies were composed largely of massive sulfides, probably pyrite and arsenopyrite, and a little quartz. During oxidation much of the vein material was leached, leaving porous masses of oxide minerals; locally so much material was leached that caves 5 to 15 feet high were formed. Powdery ore and rubble accumulated on the floors of the caves, and in places chalcedony was deposited on the rubble.

The largest ore body discovered up to the time the mine was last visited in 1955 was 180 feet long; the extent in depth had not been determined. Ore mined in $1955-56$ averaged 14 to 22 percent arsenic and 50 to 55 ounces silver and 1.75 ounces gold to the ton.

TOMBOY MINE (4)

The Tomboy mine is on the west side of Box Canyon in the NW1/4 sec. 34, T. 31 N., R. 43 E. The property consists of two unpatented claims owned by D. F. Shovelin of Battle Mountain. Vanderburg (1939, p. 25) says that the property was located by Lyman Sands and William Gibson about 1900. D. F. Shovelin, Sands, and associates in 1925 erected a 35-ton amalgamation mill in the Reese River valley in sec. 1, T. 30 N., R. 43 E., about 3 miles southeast of the mine. The mill operated for 7 months; 4,000 tons of ore was treated and concentrates valued at about $\$ 21,000$ were recovered. Subsequently, Mr. Shovelin became sole owner of the property. During the 1930's there was sporadic production by lessees, and the ore mined was shipped to smelters. In 1948 a road was constructed to the Copper Canyon Mining Co. mill a mile to the north, and 5,723 tons of ore was trucked there from the Tomboy mine for processing. The heads averaged 0.22 ounce gold to the ton, and the recovery was 0.18 ounce. The ivllowing table lists the available production data:

Production of gold, silver, copper, and lead, Tomboy mine, $1925-49$

[Compiled by U.S. Bur. of Mines; published with permission of the owner]

\begin{tabular}{|c|c|c|c|c|c|}
\hline Year & $\begin{array}{c}\text { Ore } \\
\text { (tons) }\end{array}$ & $\begin{array}{c}\text { Gold } \\
\text { (ounces) }\end{array}$ & $\begin{array}{c}\text { Silver } \\
\text { (ounces) }\end{array}$ & $\begin{array}{c}\text { Copper } \\
\text { (pounds) }\end{array}$ & $\begin{array}{c}\text { Lead } \\
\text { (pounds) }\end{array}$ \\
\hline 1925 & & 49.84 & 23 & & \\
\hline 1922--...- & $\begin{array}{l}{ }^{1} 150 \\
140\end{array}$ & $\begin{array}{r}194.92 \\
23.13\end{array}$ & $\begin{array}{l}50 \\
89\end{array}$ & & - \\
\hline 1935 & $\begin{array}{l}40 \\
58\end{array}$ & $\begin{array}{l}25.80 \\
25.80\end{array}$ & 18 & & \\
\hline $1937-\ldots$ & 232 & 64.0 & 55 & 731 & - n n n n \\
\hline 1938 1948- & 24,823 & $\begin{array}{r}13.0 \\
974.0\end{array}$ & $\begin{array}{r}11 \\
888\end{array}$ & $\begin{array}{r}161 \\
4,904\end{array}$ & 2,285 \\
\hline $1949 \ldots$ & & 52.0 & 224 & 1,023 & 570 \\
\hline
\end{tabular}

The Tomboy workings include three short adits and an open pit. The adits are partly caved as a result of the operations in the open pit (pl.12). 
The Tomboy workings are in the lower part of the Battle Formation just above the contact with the Harmony Formation. The Battle Formation strikes north and dips $15^{\circ}$ to $29^{\circ} \mathrm{W}$. in this area. The rocks are cut by many faults of small displacement that in general strike north and dip steeply to the east.

The ore minerals consist of pyrite and variable amounts of chalcopyrite, sphalerite, arsenopyrite, and galena that occur in fractures and also are disseminated throughout the conglomerate. At the surface the sulfides are oxidized, and the ore is composed mainly of iron oxides with traces of the oxidation products of the other minerals. The ore body was localized in and near fractures that cut the conglomerate, but to some extent the ore replaces the conglomerate as well away from the fractures. The fractures continue downward into the Harmony Formation, but there is noticeably less extensive metallization adjacent to them there.

MINNIE MINE (8)

The Minnie mine on the Minnie claim is in Box Canyon in the SW1/4 sec. 27 , T. 31 N., R. 43 E., and adjoins the Tomboy mine property on the northeast. The Minnie property is owned by H. B. Chessher of Reno, Nev.

The workings consist of four adits, one at an altitude of 5,775 feet on the north side of a small gully and the other three on the south side (pl. 12). In addition, there are several shallow trenches and pits. Fourteen holes were drilled, in 1942, near the workings by the International Smelting and Refining Co.

The workings explore sheared zones in the Harmony Formation and in the lower part of the Battle Formation which has been locally downfaulted. The mineralized zone is composed of highly fractured rock with disseminated auriferous pyrite, locally oxidized to iron oxides. The zone extends as much as 200 feet below the surface and has a northwestward extent of about 480 feet. The gold values are not uniformly distributed throughout the zone, but are concentrated along the more highly fractured areas. The ore in the block is reported by Mr. Chessher to average about 0.15 ounce of gold to the ton.

\section{INDEPENDENCE MINE (18)}

The Independence mine is on the ridge between Copper Canyon and Iron Canyon at an altitude of about 6,600 feet. The property consists of 16 patented claims and 27 unpatented claims. The original discovery was made by Charles Birum in the 1920's. The Alaska Treadwell Mining Co. acquired the property in 1931 and did considerable exploratory work. H. B. Chessher purchased the property in 1935 and has carried on additional exploratory work since then. There has been no production from the property.
The workings consist of 13 adits which were driven westward to explore gold-bearing conglomerate at the base of the Battle Formation (pl. 12). The portals of the adits are mostly in shale and sandstone of the underlying Harmony Formation, and they pass into the conglomerate within short distances. The structure of the Harmony Formation is complex, but the overlying Battle formation dips $10^{\circ}$ to $30^{\circ} \mathrm{W}$. The rocks have been cut and broken by north-striking faults that dip steeply east and west.

The ore bodies in the Independence mine are in the lower conglomerate of the Battle Formation adjacent to sheared zones. The ore has been localized in this favorable unit only where it was highly fractured. The geologic map shows the complex nature of the faulting in the lower conglomerate. The overlying siliceous conglomerate and underlying Harmony Formation are likewise fractured, but apparently they were less favorable for precipitation of the ore minerals.

The metallized rock is similar to the gold ore mined at the Tomboy and Copper Canyon mines. The copper content of the Independence ore is lower, as pyrite is the main sulfide mineral, and only small amounts of chalcopyrite, galena, and sphalerite are found. The ore from the fractured zone is said to average about 0.14 ounce of gold to the ton. A considerable tonnage of this grade is reported to be present throughout the area that has been explored.

Two mineralized bodies have been explored. The west body is exposed in No. 4 adit; on the southeast it is cut off by a transverse fault that strikes $\mathrm{N} .35^{\circ} \mathrm{E}$. and dips about $70^{\circ} \mathrm{NW}$.; on the east it ends against a fault that strikes about $\mathrm{N} .10^{\circ} \mathrm{W}$. and dips steeply northeast. The basal conglomerate probably continues up dip northeast of the fault and connects with the mineralized rock in adits Nos. 2 and 3. The downward extent is not known. The mineralized rock has a strike length of about 450 feet and a width of 110 to 140 feet on the No. 4 adit level.

The east mineralized body has been explored over a strike length of 1,100 feet and a width of 80 to 100 feet in short adits driven into the lower conglomerate of the Battle Formation. The conglomerate has been cut by many faults of small displacement and is weakly to moderately mineralized.

\section{WESTERN LOCK MINE (10)}

The Western Lock mine workings are on the Western Lock and Western Key claims about half a mile east of the Copper Canyon mine. The workings consist of several short adits and opencuts at altitudes of 6,150 to 6,300 feet at the head of the east fork of Box Canyon that explore copper showings along faults in quartzite 
and hornfels of the Harmony Formation. A small production during the 1870's has been reported, but the production figures are not available. In 1953 a shipment of 136.1 tons containing 0.01 ounce gold and 0.79 ounce silver to the ton and 4.52 percent copper was shipped.

This ore came from a pit at an altitude of about 6,150 feet; the pit was 90 feet long, 20 feet wide, and as much as 30 feet deep. The pit explores a fault zone that strikes N. $35^{\circ} \mathrm{W}$. and dips $65^{\circ}$ to $75^{\circ} \mathrm{SW}$. The ore minerals are malachite, chalcocite, chrysocolla, and cuprite.

An adit about 400 feet to the northwest of the pit was driven about 700 feet southward on a fault zone that $\operatorname{dips} 60^{\circ}$ to $80^{\circ} \mathrm{E}$. About 200 feet from the portal, a stope extends for 50 feet along the vein and 20 feet up dip. The material stoped was mainly malachite and chalcocite in sheared sandstone. Near the face of the adit, much pyrite was noted along the fault zone, but the copper content was low.

Another group of pits on the knoll about 500 feet west of the pit at 6,150 feet have yielded a small production. The pits follow steep fractures trending about N. $80^{\circ} \mathrm{W}$. for a strike distance of about 80 feet. A shaft 25 feet deep was sunk at the south end of one of the pits. The ore minerals noted are azurite, malachite, chrysocolla, chalcocite, and cuprite.

\section{GOLD CASH (NO MONEY) MINE (7)}

The Gold Cash mine is in the west fork of Philadelphia Canyon in the $\mathrm{SE}^{1} / 4$ sec. 27, T. 31 W., R. 43 E. The property consists of two claims, the No Money and Gold Cash claims, owned by the New London Extension Mining Co. of Denver, Colo. The workings consist of several shallow pits and an adit about 300 feet long driven along a fault that strikes east and dips $50^{\circ}$ N. The workings are in sandstone and shale of the Harmony Formation.

The Gold Cash mine has been worked by lessees intermittently since 1934. The recorded production is as follows:

Production of gold, silver, copper, and lead, Gold Cash mine, $1934-43$

[Compiled by U.S. Bur. of Mines; published with permission of the owner]

\begin{tabular}{|c|c|c|c|c|c|}
\hline Year & $\begin{array}{c}\text { Ore } \\
\text { (tons) }\end{array}$ & $\begin{array}{c}\text { Gold } \\
\text { (ounces) }\end{array}$ & $\begin{array}{c}\text { Silver } \\
\text { (ounces) }\end{array}$ & $\begin{array}{c}\text { Copper } \\
\text { (pounds) }\end{array}$ & $\begin{array}{c}\text { Lead } \\
\text { (pounds) }\end{array}$ \\
\hline${ }_{1936}$ & $\begin{array}{r}37 \\
242\end{array}$ & $\begin{array}{r}13.5 \\
125.0\end{array}$ & 181 & $\begin{array}{l}310 \\
432\end{array}$ & 517 \\
\hline $1937-$ & 44 & $\begin{array}{r}26.0 \\
26.0\end{array}$ & 15 & & \\
\hline $\begin{array}{l}1938 .- \\
1939-\end{array}$ & 256 & 6.0 & $\begin{array}{r}5 \\
431\end{array}$ & & \\
\hline 1940 & $\begin{array}{l}1,066 \\
1,061\end{array}$ & $\begin{array}{l}300.0 \\
272.0\end{array}$ & $\begin{array}{l}431 \\
856\end{array}$ & 19 & - \\
\hline 1941- & 2,115 & 473.0 & 816 & & 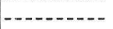 \\
\hline 1943 & $\begin{array}{l}595 \\
51\end{array}$ & $\begin{array}{r}\begin{array}{r}141.0 \\
12.0\end{array}\end{array}$ & $\begin{array}{r}238 \\
12\end{array}$ & & - \\
\hline
\end{tabular}

The primary ore minerals are mainly pyrite and arsenopyrite and a little chalcopyrite, galena, and sphalerite. The ore stoped was mainly oxidized ore containing kernels of partly oxidized sulfides. The tenor was as much as 0.60 ounce of gold and 4.5 ounces of silver to the ton. The ore occurred along the fault zone in lenticular bodies which were as much as 3 feet thick.

SILVER KING MINE (19)

The Silver King mine is in the $\mathrm{SW} 1 / 4$ sec. 22 , T. 31 N., R. 43 E., on the east side of Copper Canyon about 0.6 mile south-southeast of the Nevada mine. The property is part of the Independence group, owned by H. B. Chessher. The workings consist of two adits; the lower one at an altitude of 6,750 feet is 360 feet long, and the upper one which is a little higher is 125 feet long. Both were driven north on a fault zone parallel to the Virgin fault. The recorded production is as follows:

Production of gold and silver, Silver King mine, 1934-39

[Compiled by U.S. Bur. of Mines; published with permission of the owner]

\begin{tabular}{r|r|r|r}
\hline Year & \multicolumn{1}{|c|}{$\begin{array}{c}\text { Ore } \\
\text { (tons) }\end{array}$} & $\begin{array}{c}\text { Gold } \\
\text { (ounces) }\end{array}$ & $\begin{array}{l}\text { Silver } \\
\text { (ounces) }\end{array}$ \\
\hline 1934 & 14 & 6.4 & 56 \\
115.0 & 691 \\
\hline
\end{tabular}

MONITOR CLAIM (12)

The Monitor (Monarch) claim is in the southern part of the Independence group (pls. 3 and 5). Several short adits and cuts have been driven into the Monitor fault zone, a conspicuous iron-stained zone that strikes N. $10^{\circ}$ to $20^{\circ} \mathrm{E}$. and dips $60^{\circ}$ to $70^{\circ} \mathrm{NW}$. The workings show much iron oxide and a little pyrite along the fault zone. The material is said to assay gold, silver, and a little zinc. No shipments have been made from the claim.

BUZZARD MINE (13)

The Buzzard mine is on the ridge between Iron and Philadelphia Canyons, and in 1953 it could be reached with difficulty over a gullied road up Philadelphia Canyon. The property is at an altitude of 6,400 feet in sec. 23, T. 31 N., R. 43 E. It consists of the Buzzard, Cyclone, and Republic patented claims owned by the Gold Deposit Mining and Milling Co. of Salt Lake City, Utah.

The Buzzard vein was discovered in the 1880's and the property was one of the early producing mines in the district. The production prior to 1912 is not known, but Vanderburg (1939, p. 26) estimated that the total production amounted to more than $\$ 200,000$. In 1912 the property was worked by the Iron Canyon 
Gold Mining Co., and the ore was treated in a 20-ton cyanide plant at the mouth of Galena Canyon.

The recorded production of the Buzzard mine is as follows:

Production of gold, silver, copper, and lead, Buzzard mine,

[Compiled by U.S. Bur. of Mines; published with permission of the lessee]

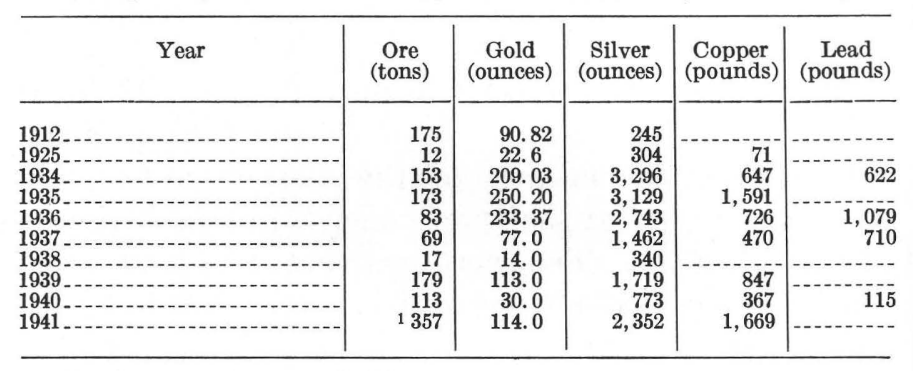

${ }^{1}$ Mainly screened dump material.

The mine workings consist of an adit 670 feet long and connecting raises and stopes that extend to the surface, which is as much as 120 feet above (pl. 12). The adit is in quartz monzonite porphyry for the first 100 feet from the portal and for the remainder of the distance is in sheared chert and shale of the Scott Canyon Formation.

The Buzzard vein follows the Buzzard fault zone that has been mapped 2 miles to the north and parallels the Plumas fault. The fault strikes north and dips $60^{\circ}$ to $75^{\circ} \mathrm{W}$.; its displacement cannot be determined in the mine area.

The ore bodies were scattered along the fault, partly as lenses and partly as small chimneys. The ore shipments contained as much as 2.81 ounces of gold and 32.9 ounces of silver. Some shipments contained a little copper and lead, mostly in the form of carbonates but partly as sulfides.

OTHER WORKINGS IN THE BUZZARD MINE AREA (NOS. 14, 15)

Several shallow workings on the ridge 0.6 to 0.8 mile east of the Buzzard mine in the E1/2 sec. 23 , T. $31 \mathrm{~N}$., R. 43 E., are mostly in the Star group of 20 lode claims and 4 placer claims owned by George A. Hinman and G. C. Hinman of Battle Mountain (pl. 12). The workings follow fault contacts between the Harmony Formation and the Scott Canyon Formation. A few tons of oxidized material has been mined, but no records of shipments are available.

One group of short adits on the north side of the ridge follows the trace of the Dewitt thrust on the Mercury claim $(14)$; in the adit at 5,946 feet altitude, a fault contact that strikes northeastward and dips $45^{\circ}$ to $60^{\circ}$ SE. may be the thrust plane. Narrow veinlets of iron oxides reported to contain a little gold and silver occur in both the Harmony Formation of the upper plate and Scott Canyon Formation of the lower plate.

The workings on the east side of the ridge on the Neptune claim (15) are along and near a normal fault that strikes north and dips $50^{\circ} \mathrm{W}$. and that drops the Harmony Formation down on the west against greenstone, shale, and chert, of the Scott Canyon Formation. A quartz monzonite porphyry dike cuts sheared greenstone at the face of the lower adit. The principal showings are along the north-striking fault in the vicinity of the inclined shaft; the shaft is now filled with water and is inaccessible.

\section{BIG FOUR (ANNEX) MINE (16)}

The Big Four mine is on the knoll west of the Buzzard mine in the SE1/4 sec. 22 , T. 31 N., R. 43 E., at an altitude of about 6,600 feet. The Big Four group consists of four unpatented claims that were located by Frank Chagnon, William and Donald MacDonald, and V. C. Clark. The property was purchased by O. E. Swackhamer in the early 1930's and is now owned by the Swackhamer family. In 1954 the claims were under option to H. B. Chessher. The workings consist of a 55 -foot shaft, a short adit, and several opencuts.

The workings explore a north-striking fault that dips steeply west. The ore shipped was silver-lead ore which was mainly composed of cerussite and iron oxides and a little unaltered galena. The shipments aggregate 77 tons which was transported by stone boat to the road in Philadelphia Canyon, and then by truck to the railroad; the 1937 shipment averaged 0.43 ounce of gold and 74 ounces of silver to the ton. The record of shipments is as follows:

Production of gold, silver, and lead, Big Four (Annex) mine, 1935-38

[Compiled by U.S. Bur. of Mines; published with permission of the owner]

\begin{tabular}{|c|c|c|c|c|}
\hline Year & $\begin{array}{c}\text { Ore } \\
\text { (tons) }\end{array}$ & $\begin{array}{c}\text { Gold } \\
\text { (ounces) }\end{array}$ & $\begin{array}{l}\text { Silver } \\
\text { (ounces) }\end{array}$ & $\begin{array}{c}\text { Lead } \\
\text { (pounds) }\end{array}$ \\
\hline 1935 & $\begin{array}{l}40 \\
14 \\
23\end{array}$ & $\begin{array}{l}6.4 \\
6.0 \\
6.0\end{array}$ & $\begin{array}{r}587 \\
1,035 \\
591\end{array}$ & $\begin{array}{r}3,726 \\
555\end{array}$ \\
\hline
\end{tabular}

NEVADA-OMAHA MINE (1)

The Nevada-Omaha mine is on the northeast side of Philadelphia Canyon half a mile north of the townsite of Bannock (pl. 3). The discovery was made by Alex Walker in 1909 (Sprenger, 1910, p. 10) on the Limelite claim.

The workings consist of several hundred feet of level workings and a shaft 350 feet deep in chert and shale of the Scott Canyon Formation (pl. 12).

According to E. Hider (oral communication, 1954), the vein that yielded the major production averaged 
2 inches in width and was composed of quartz and native gold. The vein was followed downward vertically in a shaft to 27 feet (Hill, 1915, p. 85). Other veins, seven in all, contained native gold, but none was so rich as the discovery vein. According to Sprenger (1910, p. 10 ), a mill run in 1909 of 5,500 pounds yielded $\$ 1,500$ in gold and a run of 335 pounds yielded $\$ 2,400$. Records of the U.S. Bureau of Mines show that in 1909 a total of 558 tons was milled with a recovery of 142.7 ounces gold and 11 ounces of silver.

\section{ELDORADO MINE (11)}

The Eldorado mine workings are in the NE $1 / 4$ sec. 29 , T. 31 N., R. 42 E., on the east side of Willow Creek about a mile northwest of the mouth of Copper Canyon. The property consists of three claims owned by Henry Filippini of Battle Mountain. The property has been operated intermittently by lessees; the recorded production is 90 tons of ore containing 0.75 ounce of gold and 4.9 ounces of silver to the ton and 0.25 percent copper. The workings consist of a 60 -foot vertical shaft and several shallow shafts and opencuts in recrystallized chert of the Pumpernickel Formation.

The workings are along a fracture zone that strikes N. $60^{\circ}$ E. and dips $60^{\circ}$ NW. (Hill, 1915, p. 91). The brecciated rock in the fracture zone contains pyrite, arsenopyrite, and a little galena and sphalerite.

ELKO-LANDER (21)

The Elko-Lander property is on the ridge between Copper Canyon and Willow Creek, half a mile south of the Meagher mine in sec. 21, T. 31 N., R. 43 E. The workings consist of a shaft, now inaccessible, and several shallow pits on a fault zone that strikes north and dips steeply westward. According to Schrader (1933, p. 120), Charles W. Adams shipped 20 tons of goldbismuth ore from the shaft in 1928.

\section{DEAD HORSE MINE (21A)}

The Dead Horse mine (Schrader, 1933, p. 125) adjoins the Elko-Lander workings on the south and is three-fourths of a mile northwest of the Copper Canyon mine on the ridge between Copper Canyon and Willow Creek in sec. 21, T. 31 N., R. 43 E. The workings include a 50 -foot incline, a 60 -foot crosscut, and a 22 -foot winze which follows bedding shears in chert that strike north and dip steeply west. The crushed zone along the shears contains pockets of gold-silver ore. No shipments are reported from the mine.

$$
\text { MEAGHER MINE (23) }
$$

The Meagher mine is on the ridge between Copper Canyon and Willow Creek a third of a mile west of the
Nevada mine in $\mathrm{SE}^{1} / 4$ sec. 16 , T. 31 N., R. 43 E. The property was originally located about 1900 by William Meagher and was later relocated by Charles Adams. Shipments total 94 tons of silver-lead ore according to the U.S. Bureau of Mines. The recorded production is as follows:

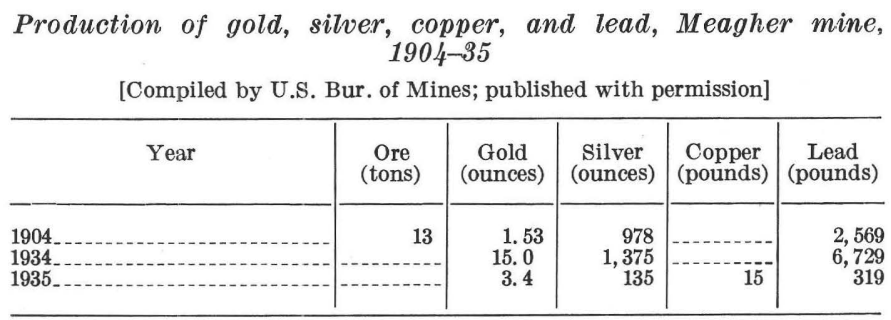

The workings are in black chert of the Pumpernickel Formation. The workings include a crosscut about 150 feet long and about 200 feet of drift along bedding which here strikes N. $10^{\circ} \mathrm{W}$. and dips $50^{\circ} \mathrm{SW}$. The drift follows bedding shears which locally contain galena, cerussite, sphalerite, and pyrite in pods up to 6 inches wide.

YELLOW BOY (ORIOLE) CLAIMS (24)

The Yellow Boy group of two claims (also known as the Oriole group) is on the divide between Copper and Galena Canyons east of the Nevada mine in $\mathrm{SW} 1 / 4$ sec. 15, T. 31 N., R. 43 E. The property was located by Frank Chagnon about 1930. Shallow workings, which were partly caved in 1951, explore a fault zone as much as 10 feet wide that strikes $\mathrm{N} .20^{\circ} \mathrm{W}$. and dips $60^{\circ}$ to $70^{\circ} \mathrm{W}$. The fault cuts through a diorite intrusive body that lies just east of the divide and the adjacent conglomerate of the Battle Formation. One shipment of 35 tons was made from the Oriole group in 1935; the shipment contained 0.49 ounce of gold and 5.7 ounces of silver to the ton.

\section{COLUMBIA GROUP (25)}

The Columbia group of four claims adjoins the Oriole claim on the east. The workings consist of several short adits and opencuts on the east side of the divide between Copper Canyon and Galena Canyon in secs. 15 and 22, T. 31 N., R. 43 E. The workings follow a northstriking fault zone, possibly a northward continuation of the Hayden fault, that has yielded a small tonnage of gold ore. In 1927 Charles Birum shipped 12 tons of ore that, according to figures furnished by the U.S. Bureau of Mines, contained 21.53 ounces of gold, 238 ounces of silver, and 39 pounds of copper.

\section{PLUMAS MINE (26)}

The Plumas mine is near the head of Butte Canyon in secs. 15 and 22 , T. 31 N., R. 43 E., about a mile west 
of the Butte mine. The property consists of the Plumas and Goodwin patented claims and a patented millsite, which are now owned by the Swackhamer family of Battle Mountain.

The Plumas mine was discovered in the 1860's and was worked during the early days of the camp, but there is no record of the production prior to 1919. A mill was erected on the property about 1919, and some ore was milled in 1920 and 1925. The total recorded production from 1919 to 1943 is 9,716 tons of ore that averaged 0.17 ounce of gold and 6.24 ounces of silver to the ton. The production record from 1919 to 1943 follows:

Production of gold, silver, copper, and lead, Plumas mine, 1919-43

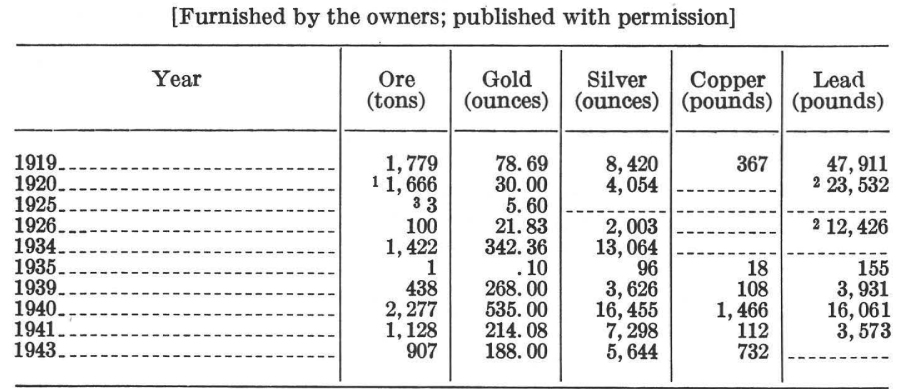

1 Ore milled, yielded 98 tons concentrates.

2 Shipments made under name of Nichlas mine.

3 Concentrates.

The workings explore the Plumas fault zone for a strike length of about 600 feet (pl. 12). The most extensive workings are on the south side of Butte Canyon and are principally on two levels, the 6100 and 6245 levels. In addition, a fair tonnage of ore has been mined from the workings on the north side of Butte Canyon where extensive stoping was done between the adit level and the surface for about 300 feet along the strike.

In the mine area the Plumas fault is a complex fault system which strikes N. $5^{\circ}$ to $20^{\circ} \mathrm{W}$. and dips $50^{\circ}$ to $75^{\circ} \mathrm{SW}$; the average dip is $65^{\circ}$. On the surface, the hanging wall consists of shale and sandstone of the Harmony Formation, and the footwall is chert and siliceous shale of the Scott Canyon Formation, but owing to the fact that the thrust contact between the Scott Canyon Formation and the Harmony Formation lies between the 6100 level and the surface, the Scott Canyon Formation makes up both the footwall and hanging wall of the fault in the lower levels of the mine. Near the face of the 6100 level, however, a small wedge of Harmony sandstone has been downfaulted, and the workings follow a shear zone in the sandstone.

The ore occurs as small veins and disseminations in the fault zone which ranges from 2 feet to 15 feet in width in the mine area. In the sulfide zone, the ore consists of auriferous pyrite, arsenopyrite, a little chalcopyrite, and in places galena and sphalerite. Oxidation of these minerals produced a ferruginous gold ore enriched in gold, silver, and lead. The gold content of ore shipped during $1939-40$ from the upper levels was as much as 0.99 ounce to the ton; the silver content ranged from 2.2 to 18.6 ounces to the ton; maximum assays of lead and copper were 2.3 and 0.12 percent, respectively. Zinc was not recorded in any shipments. Arsenic was commonly present in amounts ranging from 0.7 to 4.2 percent; 0.1 to 0.4 percent antimony was present in about half the shipments. Melanterite locally coats the walls of the drifts and in places has formed stalagmites on the floor (fig. 6).

In the deeper levels, the grade of the ore decreased as the oxidized ore gradually gave way to sulfide ore. Ore below the 6100 level is said to have been entirely sulfide ore.

CLEVELAND CLAIM (27)

The Cleveland workings are on the Cleveland claim in the NE $1 / 4$ sec. 22 , T. 31 N., R. 43 E., in a tributary of Iron Canyon. The workings consist of two adits, one on each side of the tributary, that explore a fault split off the Plumas fault zone. The workings were closed in 1955 , but they are reported to aggregate about 500 feet. A shipment of 4 tons made in 1939 is reported to have yielded 4 ounces of gold and 12 ounces of silver.

\section{GALENA CANYON AREA}

The Galena area is 12 miles southwest of the town of Battle Mountain and 21/2 miles north of Copper Canyon near the head of Galena Canyon in secs. 9, 10, 15, and 16, T. 31 N., R. 42 E. The mines in this area were discovered and developed soon after Copper Canyon, and by 1870 two smelters were in operation.

Production of the Galena mines has not been recorded separately, but by 1912 the production may have totalled about $\$ 500,000$, chiefly during the 1880 's. The largest single producer was the White and Shiloh mine, but the Trinity and Humbug-Lucky Chance mines have notable productions.

The mines in the Galena area are mainly along steeply dipping faults that cut sandstone and shale of the Harmony Formation, chert, shale, and greenstone of the Scott Canyon Formation, and conglomerate of the Battle Formation. The faults are the northern continuations of faults that were mapped in Copper and Iron Canyons, the Butte, Plumas, Hayden, Virgin, and other faults. The ore bodies were mainly in the crushed zones along the faults, but in places the ore bodies extended outward along bedding.

The ore bodies were worked for their values in silver, lead, and locally, gold. Much of the ore contained 
zinc, but as most lead smelters did not recover zinc in the early days, no payment was made for it. The ore did not contain as much copper, arsenic, or iron as typical Copper and Iron Canyon ores, but the differences in the ores are not so much in mineralogy, but mainly in the relative proportions of minerals present.

The oldest rock exposed in the Galena area is the Scott Canyon Formation which forms the footwall of the Trinity fault and is the host rock for ore bodies in the Trinity, Humbug-Lucky Chance, and Butte mines. The hanging wall or Galena block of the Trinity fault is made up of the Harmony Formation which extends westward to Galena where it is overlain unconformably by the Battle, Antler Peak, and Edna Mountain Formations. West of Galena, the Pumpernickel Formation which forms the upper plate of the Golconda thrust has been dropped down on the Virgin fault and is successively in contact with all the formations in the Galena area.

The ore bodies in the Galena area are mainly along faults and occur both as fissure fillings and replacements of crushed rock in the sheared zones. In the Trinity and Driscol mines, the ores fill fissures along fault zones. In the Blossom mine the larger ore bodies are in fractured zones in limestone of the Edna Mountain Formation, and they were probably formed by a combination of fissure filling and replacement.

The earliest discovery recorded in the Galena area was the Buena Vista mine which was located by Messrs. Robert McBeth and Fox in 1867. The Battle Mountain (now part of White and Shiloh), Trinity, White, and Shiloh mines were located within the next 2 years (Whitehill, 1873, p. 47), and mining and smelting operations were in full swing by 1871 . The White mine and Shiloh mine were operated separately at first and were later combined as the White and Shiloh Consolidated Mining Co. about 1870 (Raymond, 1874, p. 198). In the late 1870's the Silverfield Mining Co., a French company, took over the Galena properties, including the White and Shiloh, and operated them until 1893. The properties were idle most of the time from 1900 to 1930 when J. A. Langwith acquired them; the principal properties in the Galena area are now owned by Mary E. Langwith, Alice L. and Langwith Berry, and Margaret E. Steiner. In all, there are 32 claims which adjoin the Chessher and Hogle properties on the north (pl. 5).

\footnotetext{
WHITE AND SHILOH MINE (38)
}

The White and Shiloh mine workings are on the White and Phoenix claims at the townsite of Galena and on the slope to the north (pl. 13). The principal production came from workings below the valley floor which have been flooded since the 1900's. The extent of the workings is shown on the section on plate 13 .
The deepest level is about 200 feet below the surface. The property is now owned by F. Langwith Berry and other heirs of the Langwith Estate.

The White and Shiloh ore was mined and hauled by tramway to a mill a few hundred feet below the mine (Raymond, 1874, p. 198-199). Here the ore was concentrated by jigging, and the concentrate, which assayed from $\$ 300$ to $\$ 400$ a ton, was shipped to San Francisco.

Hill $(1915$, p. 85) reports that the "production from veins $* * *$ held by the French Company is between 4 and 6 million dollars in silver and gold $* * *$. The White and Shiloh vein $* * *$ was a large producer in the early eighties $* * * . "$ The present writers find no basis in official records for production figures of such magnitude. The major production in the early days was in the period 1871-74; after 1877, the tonnage for the entire district fell off markedly, averaging annually less than 600 tons of ore valued at about $\$ 70$ a ton from 1881 to 1883 . The following table of production was assembled from several sources; the amounts given are more likely to be under rather than over :

Production from the White and Shiloh mine, 1870-75

[Compiled from Raymond (1873, p. 216-217), Whitehill (1875, p. 153, 173), and Whitehill $(1877$, p. 79$)$. These figures are incomplete; Whitehill $(1877, \mathrm{p} .79)$ reports a production of $\$ 400,000$ by 1876$]$

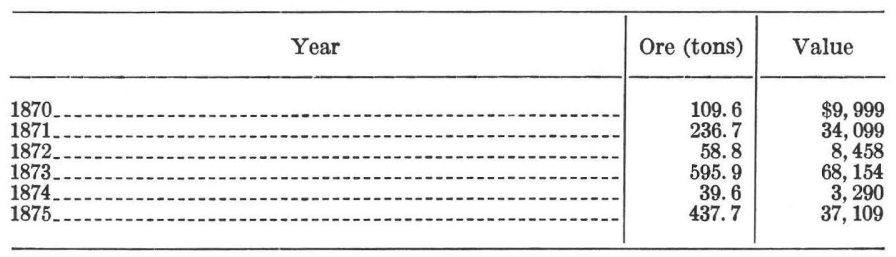

More recent production from the White and Shiloh mine appears to be mainly shipments of tailings from the dumps at Galena. The recorded shipments are as follows:

Production of gold, silver, lead, and zinc, White and Shiloh mine, $1937-51$

[Furnished by U.S. Bur. of Mines; published with permission of the owner]

\begin{tabular}{c|r|r|r|r|r}
\hline Year & $\begin{array}{c}\text { Ore } \\
\text { (tons) } 1\end{array}$ & $\begin{array}{c}\text { Gold } \\
\text { (ounces) }\end{array}$ & $\begin{array}{r}\text { Silver } \\
\text { (ounces) }\end{array}$ & $\begin{array}{r}\text { Lead } \\
\text { (pounds) }\end{array}$ & $\begin{array}{c}\text { Zinc } \\
\text { (pounds) }\end{array}$ \\
\hline & 54 & 7.0 & 725 & 5,431 & \\
\hline 1937 & 48 & 4.0 & 393 & 2,857 & \\
\hline 1940 & & 2.0 & 83 & 896 & 1,424 \\
\hline
\end{tabular}

1 Shipped by Johnson and Moore under name of Galena mine.

The White and Shiloh property includes workings on the hill to the north, which were formerly called the Battle Mountain mine (Whitehill, 1873, p. 48). As the company formerly operating the Copper Canyon mine was also referred to as the Battle Mountain Mining Co., considerable confusion has been introduced into the literature on the district. 
The productive part of the White and Shiloh mine workings was under water in 1949 and could not be visited, but some of the upper levels were accessible and were mapped (pl. 13). The upper workings are in sandstone and shale of the Harmony Formation and in conglomerate of the Battle Formation. The workings explore fault strands of the Virgin fault (locally called the Battle Mountain fault) and parallel faults.

The primary ore minerals noted are pyrite, galena, and sphalerite. These minerals filled open spaces along fault zones and also replaced limy beds in the Harmony and Battle Formations. Much of the ore mined during the 1870's was high-silver ore; Whitehill (1873, p. 48) reports that 200 tons shipped from a level 75 feet below the collar of the White shaft yielded $\$ 350$ a ton, and that ore from a level 30 feet lower contained wire and ruby silver. Presumably these ores owed their high values to enrichment near the water table.

No records are available on the size, shape, and grade of the ore shoots mined in the White and Shiloh mine. Whitehill $(1879$, p. 71$)$ reports that a shoot 30 feet long, 6 feet high, and 3 feet wide that had promise of yielding ore worth $\$ 17,000$ was being mined in 1877 . It is presumed that the ore shoots mined were in crushed zones along the Virgin fault zone.

\section{BLOSSOM MINE (35)}

The Blossom mine, which was described by Hill (1915, p. 86) under the name of Avalanche claim, is on the Blossom claim in sec. 16, T. 31 N., R. 43 E., about a third of a mile south of the townsite of Galena. The principal adit is at an altitude of 6,300 feet.

The workings of the Blossom mine total 1,350 feet of drifts, raises, crosscuts, and winzes, exclusive of raises and working levels in the stopes (pl. 13). The mine is accessible by two surface openings: through an adit on the 6300 level, and down an inclined shaft that passes 125 feet down through the stopes from the surface to the 6300 level.

No detailed record of the production is available. Figures furnished by the owners indicate that production prior to 1912 totalled about 1,000 tons averaging 0.088 ounce of gold, 14.32 ounces of silver to the ton, and 11.34 percent lead. This production was made mainly in the 1880 's.

The workings of the Blossom mine explore the Virgin fault zone which consists of three major strands in this area; all the strands strike N. $10^{\circ}$ to $30^{\circ} \mathrm{W}$. and dip steeply westward. The fault drops the Pumpernickel Formation down into contact with both the Harmony Formation and the Edna Mountain Formation. The middle strand, which is within the Edna Mountain
Formation, has yielded most of the ore stoped in the Blossom mine. The displacement on the east strand, which lies east of the mine workings, places the Edna Mountain Formation in contact with both the Harmony Formation and the Battle Formation (pl. 3).

The ore that has been mined consists of a mixture of iron oxides, cerussite, anglesite, and gypsum, containing remnants of primary pyrite, galena, and sphalerite. Calcite and quartz are the gangue minerals. The ore bodies replaced calcareous shale, limestone, and conglomerate of the Edna Mountain Formation in sheared zones mainly along the middle strand of the Virgin fault.

Near the portal, the 6300 level drift is along the west strand of the Virgin fault. This part of the fault consists of a limonite-stained breccia zone ranging from 3 to 12 feet wide, and in places contains pods and veinlets of pyrite. The fault branches about 370 feet southeast of the portal; 80 feet beyond the branching, a wedge of Edna Mountain conglomerate and calcareous shale has been downfaulted between two strands of the Virgin fault.

The west strand of the fault which was explored 80 feet south-southeastward beyond the intersection contained only pyrite, mostly in chert of the Pumpernickel Formation in the hanging wall; the Edna Mountain formation in the footwall, which consists of calcareous shale and sandstone, contains abundant massive limonite, hermatite, and calcite in vugs. The middle strand of the fault was explored for 340 feet southward beyond the intersection. About 60 feet from the intersection this strand becomes less distinct and breaks up into parallel, discontinuous shears within conglomerate of the Edna Mountain Formation. The shear zone was explored an additional 260 feet on the 6300 level, and narrow veinlets of partially oxidized galena and iron oxides were found, but no ore was stoped on the level.

The principal stope began about 25 feet above the 6300 level. The stope was about 100 feet long, extended up dip about 80 feet, and averaged about 5 feet wide.

\section{BUENA VISTA MINE (34)}

The Buena Vista mine is at an altitude of 6,350 feet just north of the pass between Copper and Galena Canyons. It was the first discovery in Galena Canyon and was located by McBeth and Fox in 1867. Shipments in the 1870's are said to have contained as much as $\$ 150$ a ton in silver and 60 percent lead. Records of shipments since 1935 show a significant gold content and much lower silver and lead content. The production record from 1935 to 1940 is as follows: 
Production of gold, silver, copper, and lead, Buena Vista mine, $1935-40$

[Furnished by the U.S. Bur. of Mines; published with permission of the owner]

\begin{tabular}{|c|c|c|c|c|c|}
\hline Year & $\begin{array}{c}\text { Ore } \\
\text { (tons) }\end{array}$ & $\begin{array}{c}\text { Gold } \\
\text { (ounces) }\end{array}$ & $\begin{array}{c}\text { Silver } \\
\text { (ounces) }\end{array}$ & $\begin{array}{c}\text { Copper } \\
\text { (pounds) }\end{array}$ & $\underset{\text { (pounds) }}{\text { Lead }}$ \\
\hline 1935 & $\begin{array}{r}37 \\
402 \\
94\end{array}$ & $\begin{array}{l}22.7 \\
97.0 \\
23.0\end{array}$ & $\begin{array}{r}305 \\
3,756 \\
519\end{array}$ & $\begin{array}{l}143 \\
137\end{array}$ & $\begin{array}{r}2,571 \\
13,213 \\
5,104\end{array}$ \\
\hline
\end{tabular}

The workings include several shallow shafts and opencuts and about 600 feet of underground workings (pl. 13). The prinicpal workings are reached by a crosscut 200 feet long from the portal to the Buena Vista fault; drifts continue along the fault and on parallel structures. The workings are entirely in highly sheared and altered chert and shale of the Pumpernickel Formation.

Sulfide minerals in the primary ore bodies are pyrite and a little galena and sphalerite which occur in crushed zones along faults. Above the adit level the sulfides have been oxidized. It is reported that some of the oxidized ore mined in the early days was rich in silver, but none of this ore was seen in the workings at the time of visit in 1951. Assays of sulfide ore in the stoped area near the face are reported to show 0.08 to 0.5 ounce of gold and 2 to 4 ounces of silver to the ton, and 1 to 2 percent lead, and 1.3 to 2 percent zinc.

The Buena Vista fault zone and parallel faults also can be traced through the Star and Nevada claims. Showings of silver-lead ore are reported on these claims, and it is possible that small ore bodies were stoped in the early days, but the operations were probably small in scale.

$$
\text { HARD TIMES CLAIM (37) }
$$

The Hard Times claim adjoins the Blossom claim on the north and also is traversed by the Virgin fault zone. A shaft reported to be about 98 feet deep was sunk on the fault zone, and drifts were run to the north and south of the shaft. Showings of lead-silver ore in the workings are said to be of good grade, but no shipments are reported.

In 1941 and 1948 ore was shipped from the shaft dump and from a surface cut on the Virgin fault. The results of the shipments are as follows:

Production of gold, silver, copper, and lead, Hard Times claim, $1941-48$

[Furnished by the U.S. Bur. of Mines; published with permission of the owner]

\begin{tabular}{r|r|r|r|r|r}
\hline Year & $\begin{array}{c}\text { Ore } \\
\text { (tons) }\end{array}$ & $\begin{array}{c}\text { Gold } \\
\text { (ounces) }\end{array}$ & $\begin{array}{c}\text { Silver } \\
\text { (ounces) }\end{array}$ & $\begin{array}{r}\text { Copper } \\
\text { (pounds) }\end{array}$ & $\begin{array}{c}\text { Lead } \\
\text { (pounds) }\end{array}$ \\
\hline 1941 & $\begin{array}{r}59 \\
1948 \ldots\end{array}$ & $\begin{array}{r}5 \\
18\end{array}$ & $\begin{array}{r}412 \\
989\end{array}$ & 307 & $\begin{array}{r}3,828 \\
15,618\end{array}$ \\
\hline
\end{tabular}

736-007 O-65-5
BON AMI CLAIM (45)

The Bon Ami claim is in Galena Canyon about a third of a mile northwest of the townsite of Galena. The workings consist of an adit 20 feet long driven on a fault zone that separates Antler Peak Limestone from conglomerate of the Battle Formation. The fault strikes N. $10^{\circ}$ to $20^{\circ} \mathrm{W}$. and dips $65^{\circ} \mathrm{SW}$. An ironstained crushed zone 3 to 5 feet wide along the fault contains lead-silver metallization. A shipment of 38 tons made in 1940 contained 0.23 ounce of gold and 6.1 ounces of silver to the ton and 0.10 percent copper and 5.7 percent lead.

\section{HUMBOLDT CLAIM (39)}

The Humboldt claim adjoins the townsite of Galena on the east. The workings consist of a shaft and a drift reported to be 164 feet long at the bottom of the shaft. The drift follows a quartz-sulfide vein striking N. $10^{\circ}$ W. in sandstone and shale of the Harmony Formation and in quartz monzonite porphyry. The sulfide minerals on the dumps include pyrite, galena, chalcopyrite, sphalerite, and arsenopyrite. No shipments have been made from the claim.

SPANISH AND CELIA CLAIMS (36)

The Spanish and Celia claims are a quarter of a mile east of Galena and extend across Duck Creek. A vein that strikes N. $10^{\circ} \mathrm{E}$., dips $75^{\circ} \mathrm{NW}$., and is from 2 to 10 inches wide is exposed in a short adit on the Spanish claim (Hill, 1915, p. 87). The vein continues across Duck Creek to the Celia claim where it is exposed in a shaft. The vein is reported to have yielded a small production, mainly from the workings on the Spanish claim.

TRINITY MINE (ATLAS 40; ARMOR 42)

The Trinity mine is in tributaries of Cow Canyon, a tributary of Galena Canyon, about three-fourths of a mile northeast of the townsite of Galena in the SW1/4 sec. 10, T. 31 N., R. 43 E. The workings are mainly on the Atlas (40) and Armor (42) claims.

The Trinity mine is mentioned in the biennial reports of the State Mineralogist as early as 1871 (Whitehall, 1873, p. 48). At that time the vein had been explored to a depth of 30 feet. In 1871 a 15 -stamp mill was erected at the mouth of Butte Canyon to treat ore from the Trinity and Butte mines. As the silver in the ore was not saved by the concentration process used, the mill was closed down. Subsequently, some of the tailings were shipped by Walter Johnson and L. C. Moore of Galena under the name Jay Emm mine. In 1875 the Trinity mine was owned by J. A. Blossom. The production during the following years has not been recorded, but it is reported that 14,000 tons of ore 
had been mined prior to 1912 and had been milled at Galena with a concentration ratio of $10: 1$. From 1934 to 1951 the mine produced 3,760 tons of ore which averaged 0.08 ounce of gold and 12.1 ounces of silver to the ton, and 3.9 percent lead. Available production data is as follows:

Production of gold, silver, copper, lead, and zinc, Trinity mine, 1875-1951

[Figures prior to 1934 furnished by the owners; other figures furnished by U.S. Bur. of Mines; published with permission]

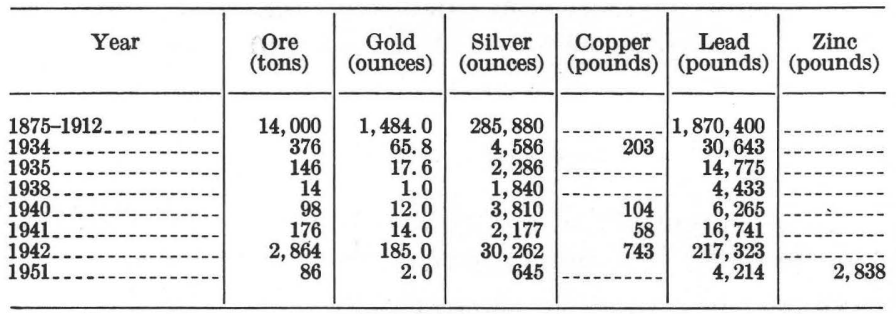

The workings of the Trinity mine (42) include an adit level 700 feet long, an inclined shaft that passes through the stope and extends 70 feet below the adit level, and several short adits and open pits (pl. 13). The main adit is at an altitude of about 6,040 feet; stopes extend from a point about 540 feet from the portal up to the surface. At 25 feet above the level, the stope is about 210 feet long. Except for stoping above the level, the workings probably are little changed since 1912 when Hill $(1915$, p. 87) visited the mine.

The workings of the Trinity mine explore the Trinity fault zone which cuts chert, shale, and greenstone of the Scott Canyon Formation and arkosic sandstone and shale of the Harmony Formation. The Trinity fault is a normal fault that strikes N. $10^{\circ}$ to $30^{\circ} \mathrm{E}$. and dips $50^{\circ}$ to $75^{\circ} \mathrm{NW}$. in the mine area. On the surface, the Scott Canyon Formation forms the footwall of the fault and the Harmony Formation the hanging wall, but as the Dewitt thrust between the two formations is only about 50 feet below the surface, the Scott Canyon Formation forms both the hanging wall and the footwall on the adit level (pl. 13). Most of the production has come from an ore body which was almost completely stoped for a distance of about 130 feet along the strike and averaged 35 feet high and 12 feet wide.

The ore is composed of galena, sphalerite, pyrite, and a little chalcopyrite and stibnite, associated with calcite and quartz. Oxidation extended about 200 feet below the surface, and as most of the stoping was in the oxide zone, a large portion of the ore was made up of iron oxides, cerussite, anglesite, and silver and gold. Near the bottom of the oxidized zone, the ore contained pods of galena surrounded by cerussite.

Other workings on the Atlas claim (40) on the Trinity fault south of the productive area show that the fault continues, but, thus far, no ore bodies have been discov- ered there. The adit on the Galena Canyon road is reported to have followed the fault for about 300 feet; the adit was caved when visited in 1954 .

\section{OTHER WORKINGS ON THE TRINITY FAULT}

The Trinity fault zone has been traced for more than a mile north of the Trinity mine workings. Many prospects have been opened on the fault zone, but only two of them have yielded any production. These two are the Eagle and Moonlight properties.

Eagle mine (48)

The Eagle mine is in the north fork of Cow Canyon, half a mile north of the Trinity mine, on the line between secs. 3 and 10, T. 31 N., R. 43 E. The property consists of the Gray, Blue, and Black Eagle claims which were located by George Weber in 1930. The group was relocated by Ernest Hider in June 1954. Shipments from the property total 13 tons in 1937 that contained 0.03 ounce of gold and 4.7 ounces of silver to the ton, and 4.43 percent lead, and 2 tons in 1942 that contained 0.50 ounce of gold and 26 ounces of silver to the ton, and 13 percent lead.

The Trinity fault zone has been explored in five short adits on the Eagle group. Three of these adits are shown on plate 13. The adits at altitudes of 6,050 and 6,150 feet were driven on the Trinity fault which here has been offset by a northwestward-striking reverse fault shown in the upper adit and near the face of the lower adit.

The ore shipped came mainly from the 6,150 adit. The ore minerals, which are accompanied by quartz gangue, are pyrite, galena, and a little sphalerite.

\section{Moonlight mine (47)}

The Moonlight group of two claims is in the west fork of Cow Canyon a quarter of a mile north-northeast of the Trinity mine. The original locator is not known; the property was relocated by Ernest Hider in 1943, and in 1955 it was owned by N. Pesi of Battle Mountain.

The production of the Moonlight mine totals 86 tons which came principally from the 6050 and 6064 adits. The 1948 shipment averaged 0.08 ounce of gold and 23.9 ounces of silver to the ton, 3.7 percent lead, and 1.2 percent zinc; minor elements included 0.16 percent arsenic and 0.35 percent antimony. The production is as follows:

Production of gold, silver, copper, lead, and zinc, Moonlight
mine, 1919-48

[Furnished by U.S. Bur. of Mines; published with permission of the owner]

\begin{tabular}{|c|c|c|c|c|c|c|}
\hline Year & $\begin{array}{c}\text { Ore } \\
\text { (tons) }\end{array}$ & $\begin{array}{c}\text { Gold } \\
\text { (ounces) }\end{array}$ & $\begin{array}{c}\text { Silver } \\
\text { (ounces) }\end{array}$ & $\begin{array}{c}\text { Copper } \\
\text { (pounds) }\end{array}$ & $\begin{array}{c}\text { Lead } \\
\text { (pounds) }\end{array}$ & $\begin{array}{c}\text { Zinc } \\
\text { (pounds) }\end{array}$ \\
\hline 1919 & $\begin{array}{r}7 \\
37 \\
42\end{array}$ & $\begin{array}{l}0.33 \\
2.00 \\
3.00\end{array}$ & $\begin{array}{l}273 \\
329 \\
984\end{array}$ & $\begin{array}{r}113 \\
69\end{array}$ & $\begin{array}{l}2,105 \\
4,198 \\
3,098\end{array}$ & 978 \\
\hline
\end{tabular}


The workings consist of four adits of which three are shown on plate 13. The adits explore the Trinity fault zone which here drops the Harmony Formation against the Scott Canyon Formation. The fault is a breccia zone as much as 20 feet wide containing fragments of rocks from both formations. Pyrite is the principal sulfide mineral noted in the shear zone. Locally, the pyrite is accompanied by galena and a little sphalerite and chalcopyrite.

\section{DRISCOL (DENVER-NEVADA) MINE (46)}

The Driscol mine property consists of three claims on the north side of Galena Canyon about half a mile north of the townsite of Galena in the SW1/4 sec. 10, T. 31 N., R. $43 \mathrm{E}$. The workings are at altitudes of 6,460 to 6,640 feet, and they include six adits and connecting workings having a total length of about 2,035 feet (pl.13).

Hill (1915, p. 87) states that the property was worked during the 1870's from four adits; evidently two of the adits have been driven since his visit in 1912 . The workings explore a fault zone that strikes about N. $25^{\circ} \mathrm{E}$. and dips $42^{\circ}$ to $75^{\circ} \mathrm{NW}$. and cuts sandstone and shale of the Harmony Formation. The early production of the Driscol mine is not known. Shipments since 1916 that have been recorded by the U.S. Bureau of Mines are given in the following table:

Production of gold, silver, copper, and lead, Driscol mine, $1916-43^{1}$

[Furnished by U.S. Bur. of Mines; published with permission of the owner]

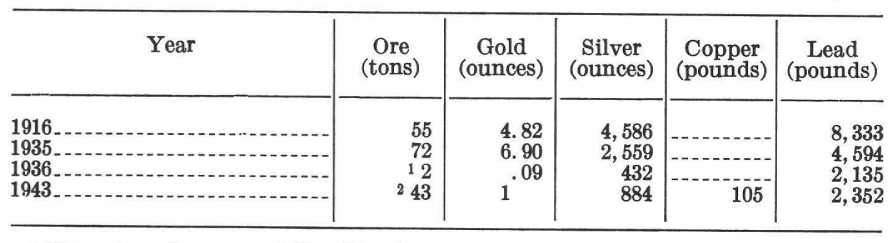

1 Shipped under name of Harriet mine.

2 Shipped under name of Galena High Line mine.

The 1935 shipment averaged 0.10 ounce of gold and 35 ounces of silver to the ton and 3 percent lead; the 1936 shipment contained 0.045 ounce of gold and 216 ounces of silver to the ton and 5.08 percent lead. A sample of galena collected from one of the stopes assayed 222 ounces of silver and 75 percent lead. Evidently the high silver content of the 1936 shipment was due to the presence of a silver-bearing mineral other than galena.

The ore minerals are galena, sphalerite, and pyrite in quartz and calcite gangue. The galena has been oxidized to cerussite and anglesite, the sphalerite to smithsonite, and the pyrite to iron oxides in the upper workings. The ore bodies ranged from a few inches to 3 feet wide and were highly lenticular along the strike and downdip. The lowest adit was farther from the surface than the others and consequently showed less oxidation along the fault. Pockets of pyrite, galena, and sphalerite from 2 to 18 inches wide are scattered along the drift for nearly 500 feet, but apparently none of them had been rich enough to mine. The main ore shoots have been localized where the fault zone cuts sandstone; where the walls are shale, the fault zone is generally barren.

\section{HUMBUG-LUCKY CHANCE MINE (33)}

The Humbug-Lucky Chance mine is about threequarters of a mile southeast of Galena in Humbug Canyon near the center of sec. 15, T. 31 N., R. 43 E. The property consists of three claims which were formerly owned by the Thurber estate, and in 1955 it was owned by $\mathrm{H}$. B. Chessher, Reno, Nev.

The workings follow the Plumas fault which strikes N. $5^{\circ}$ to $20^{\circ} \mathrm{W}$. and dips $40^{\circ}$ to $75^{\circ} \mathrm{SW}$. (pl. 13). The fault separates the sandstone and shale of the Harmony Formation on the west from the black chert and shale of the Scott Canyon Formation on the east. The fault is a shear zone 10 to 20 feet wide which is mainly in the thinly bedded shale and chert of the Scott Canyon Formation.

The workings are on both sides of Humbug Canyon and range in altitude from 6,000 to 6,100 feet. They include an opencut 120 feet long and level workings extending 420 feet to the north and 280 feet to the south. A shaft on the north side of the cut is filled with water at 10 feet below the 5949 level. The shaft is reported to have a total depth of 150 feet.

The Humbug-Lucky Chance mine has been intermittently productive since the 1870 's but the recorded production dates only from 1921 . The production is given in the following table:

Production of gold, silver, lead, copper, and zinc, HumbugLucky Chance mine, 1921-43

[Furnished by H. B. Chessher; published with permission]

\begin{tabular}{|c|c|c|c|c|c|c|}
\hline Year & $\begin{array}{c}\text { Ore } \\
\text { (tons) }\end{array}$ & $\begin{array}{c}\text { Gold } \\
\text { (ounces) }\end{array}$ & $\begin{array}{c}\text { Silver } \\
\text { (ounces) }\end{array}$ & $\begin{array}{c}\text { Copper } \\
\text { (pounds) }\end{array}$ & $\underset{\text { (pounds) }}{\text { Lead }}$ & $\underset{\text { (pounds) }}{\text { Zinc }}$ \\
\hline $\begin{array}{l}1921 \\
1927 \\
1930 \\
1932 \\
1933 \\
1934 \\
1934 \\
1935 \\
1935 \\
1936 \\
1937 \\
1943\end{array}$ & $\begin{array}{r}850 \\
136 \\
1240 \\
169 \\
87 \\
179 \\
194 \\
11,037 \\
23 \\
1372 \\
177 \\
52 \\
103\end{array}$ & $\begin{array}{r}172.00 \\
32.86 \\
2.97 \\
77.98 \\
94.00 \\
32.47 \\
80.74 \\
251.54 \\
7.90 \\
90.00 \\
79.00 \\
16.00 \\
18.00\end{array}$ & $\begin{array}{c}154 \\
342 \\
1 \\
405 \\
7.83 \\
266 \\
1,053 \\
4,544 \\
109 \\
1,457 \\
880 \\
158 \\
229\end{array}$ & $\begin{array}{r}-130 \\
-10 \\
-10\end{array}$ & $-1-1-1-1$ & [יני \\
\hline
\end{tabular}

1 Shipped by E. Hider under name of Lucky Chance mine.

2 Amalgamated tailings.

The only primary ore minerals identified were pyrite and arsenopyrite which are altered to iron oxides and jarosite in the workings. Oxidation extends 70 feet be- 
low the surface north of the pit and about 40 feet south of the pit. The shipping records show small amounts of lead, zinc, and copper, and it is therefore probable that galena, sphalerite, and chalcopyrite were constituents of the primary ore.

The principal stopes were south of the pit in the oxidized zone. The stoping width was highly variable and generally ranged from 2 to 4 feet. The ore was selectively mined and sorted. The tenor in gold ranged from 0.10 ounce to more than 2 ounces a ton. The silver content was erratic and was as much as 9 ounces a ton. According to F. Sommer Schmidt ${ }^{4}$ ore mined prior to 1900 contained as much as $\$ 50$ a ton in gold and silver (gold at $\$ 20.67$ ounce). Samples taken by Schmidt from the stopes in 1922 showed that the oxide ore remaining averaged about $\$ 8$ a ton and the sulfide ore about $\$ 1.20$ a ton.

APEX ANTIMONY MINE (41)

The Apex Antimony mine is on the ridge between Cow Canyon and Scott Canyon at an altitude of 6,050 feet. The property consists of five claims, the Apex and Apex Nos. 1-4, which are owned by N. Pesi of Battle Mountain. Records of production are incomplete, but it is reported by Mr. Pesi that about 150 tons has been shipped since 1939. The ore consisted mainly of stibnite and some yellow antimony oxides. The tenor of ore shipped ranged from 35 to 46 percent antimony and 0.22 to 0.27 percent arsenic.

The workings consist of a vertical shaft 150 feet deep having drifts on the 50,100, and 150 levels aggregating about 125 feet. The ore bodies stoped were lenses in a north-striking vertical fault. On the 50 level the ore was as much as 4 feet wide and 14 feet long; it was stoped downward for 30 feet. The ore lenses pitched steeply to the north.

NORTH BUTTE WORKINGS (31)

The North Butte workings are a little more than a mile east of Galena at the mouth of Cow Canyon and a third of a mile northwest of the Sioux group. The workings consist of two short adits, one just above the valley floor and the other about 38 feet higher. The workings explore the northward continuation of the Butte fault zone which here strikes about N. $15^{\circ} \mathrm{W}$. and dips $45^{\circ}$ to $58^{\circ} \mathrm{SW}$. The workings are mainly in carbonaceous shale, chert, and greenstone of the Scott Canyon Formation; a quartz monzonite porphyry dike 15 to 20 feet wide is locally present in the footwall block of the fault. According to Hill (1915, p. 84), the ore minerals are cupriferous pyrite, galena, and sphalerite associated with quartz. He also reports that one specimen contained argentite in cracks in the other minerals.

4 Report (1923) in files of the Copper Canyon Mining Co.

\section{ANNIE BLAINE CLAIM (44)}

The Annie Blaine claim, which lies north of the Galena townsite and adjoins the White claim on the east, is explored by an adit 170 feet long at an altitude of 6,400 feet. The adit follows a fault zone that strikes northward and dips $45^{\circ}$ to $60^{\circ}$ eastward in sandstone and shale of the Harmony Formation. The crushed zone along the fault is from 1 to 2 feet wide and locally contains pockets of iron oxides, cerussite and a few relict galena crystals. A few tons of this material has been stoped, but the production is not known. A selected sample of nearly pure galena was assayed in the laboratory of the Copper Canyon Mining Co. and found to contain 94.7 ounces of silver to the ton.

BRYAN MINE (32)

The Bryan mine property adjoins the Humbug-Lucky Chance property on the north and is in the north half of sec. 15, T. 31 N., R. 43 E. The workings, which were largely inaccessible in 1953, include several adits and a shaft along the northward extension of the Plumas fault which here strikes north and dips steeply westward.

The production of the Bryan mine is not known, but a little ore was milled in a 10-stamp amalgamating plant near Galena which was operated intermittently. In 1917, according to the U.S. Bureau of Mines, 80 tons of ore was milled with the recovery of 19.8 ounces of gold and 205 ounces of silver. Later, production of 55.9 ounces of gold and 57 ounces of silver was reported, but the tonnage milled was not stated.

According to Hill (1915, p. 88), the Plumas fault zone here ranges from a few inches to 12 feet wide. The fault is filled with white quartz and pyrite in the narrow parts and pyritized crushed wallrock in the wider parts.

F. Sommer Schmidt (see footnote 3) sampled the Bryan workings and took 151 samples that averaged $\$ 4.39$ in gold and silver to the ton in the oxidized ore and $\$ 1.30$ in the sulfide ore.

ACE OF DIAMONDS CLAIM (43)

The Ace of Diamonds claim is in the SW1/4 sec. 10, T. 31 N., R. 43 E., at an altitude of 6,250 feet about a quarter of a mile southeast of the Driscol mine. The property is owned by A. C. Fuller and associates. The workings include two open pits, each 12 feet by 20 feet, that explore a shear zone 6 inches wide which strikes north and dips $65^{\circ} \mathrm{W}$. in sandstone of the Harmony Formation. The shear zone contains quartz and a little pyrite and galena. No production is reported from the workings.

Other workings, now caved, about a quarter of a mile to the south on the Celia claim (36), are evidently on the same fault zone which here dips $70^{\circ} \mathrm{W}$. 
BUTTE (GOLD BUtTE) MINE (28)

The Butte mine is in sec. 14, T. 31 N., R. 43 E., near the mouth of Butte Canyon, a tributary of Galena Canyon (pl. 13). The workings range in altitude from 5,590 to 5,795 feet, are along a fault zone that strikes $\mathrm{N}$. $5^{\circ}$ to $25^{\circ} \mathrm{W}$. and dips $30^{\circ}$ to $70^{\circ} \mathrm{SW}$., and are in chert and shale of the Scott Canyon Formation. The property consists of six lode claims and one placer claim and is owned by John C. Starr of Kansas City, Missouri.

The workings consist of two adits and connecting workings and several shallow pits. The most extensive workings are on the north side of the canyon (pl. 13) where the vein has been explored for 380 feet along the strike and 180 feet down dip; this adit yielded the major part of the early production.

The Butte mine was discovered in 1866 and was worked from then until 1871; the mine had a reported production of $\$ 240,000$. Raymond (1873, p. 216-217) states that the ore contained from $\$ 131$ to $\$ 175$ a ton. In the summer of 1871, a 15-stamp mill was erected at the mouth of Butte Canyon; the mill was operated for about a month on ore from the Butte and Trinity mines and was then closed because the silver recovery was not satisfactory. In $1875 \mathrm{~J}$. A. Blossom took the property over and is credited with a small production. The mine was idle most of the time until 1936 when shipments were resumed by Mr. Starr. In 1939 the property was leased by Claude A. Post, who began shipments; between 1940 and 1947, he shipped 37 carloads that contained 2,000 tons averaging about $\$ 10$ per ton in net smelter returns.

The production is summarized in the following table:

Production of gold, silver, copper, and lead, Butte mine, $1866-1947$

\begin{tabular}{|c|c|c|c|c|c|c|}
\hline Year & $\begin{array}{c}\text { Ore } \\
\text { (tons) }\end{array}$ & $\begin{array}{c}\text { Gold } \\
\text { (ounces) }\end{array}$ & $\begin{array}{c}\text { Silver } \\
\text { (ounces) }\end{array}$ & $\begin{array}{c}\text { Copper } \\
\text { (pounds) }\end{array}$ & $\begin{array}{c}\text { Lead } \\
\text { (pounds) }\end{array}$ & Value 1 \\
\hline $\begin{array}{l}1866-70 \\
1871 \\
1872 \\
1875 \\
1895 \\
1936-38 \\
1940-47\end{array}$ & $\begin{array}{c}22,000 \\
32,360 \\
788 \\
19.5 \\
80 \\
197.5 \\
2,000\end{array}$ & $\cdots$ & $\cdots$ & - & 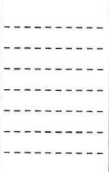 & $\begin{array}{c}\$ 240,000.00 \\
54,132.40 \\
14,955.43 \\
796.00 \\
12,000.00(?) \\
6,782.81 \\
18,000.00\end{array}$ \\
\hline
\end{tabular}

1 From old reports compiled by R. M. Oliver.

2 Estimated.

3 Raymond (1873, p. 217) reports 1871 production was only 1,600 tons valued at $\$ 12.00$ a ton.

${ }_{4}^{4}$ Figures furnished by the U.S. Bur. of Mines; published with permission of the ${ }^{4}$ Fig
lessor.

The ore minerals at the Butte mine include pyrite, now largely oxidized to iron oxides in the upper workings, and cerussite. Shipments made in 1945-1947 showed as much as 0.2 percent copper; the forms in which the copper occurs is not known, but it may be present as black copper oxide. Smelter assays also show the presence of small amounts of arsenic and antimony.

The ore bodies are along the Butte fault. The largest ore body mined in the North workings was 200 feet long and extended down dip for 60 feet; the average thickness of the stope was about 3 feet and ranged from 1 to 5 feet. The early shipments of ore ranged in grade from $\$ 10$ to $\$ 106$ a ton (gold at $\$ 20.67$ per ounce). The tenor of these shipments in silver and gold is not known but ore shipped by Mr. Post since 1940 averaged about 0.10 ounce of gold and 10 ounces of silver to the ton.

$$
\text { POST MINE (28A) }
$$

The Post mine, which adjoins the Butte mine on the south, is owned by Claude A. Post of Battle Mountain. The workings consist of an adit 280 feet long from which stopes extend 75 feet up the dip of the vein (pl. 13).

The workings are on the Butte fault which here strikes N. $30^{\circ} \mathrm{W}$. and dips $55^{\circ}$ to $80^{\circ} \mathrm{SW}$. The ore bodies on the adit level are mainly pyrite-quartz lenses in the shear zone. In the upper parts of the stope, the pyrite is largely oxidized to limonite and hematite. Shipments in 1945-47 totaled 653 tons that gave the following smelter returns:

Production of gold, silver, copper, and lead, Post mine,

[Furnished by U.S. Bur. of Mines; published with permission of the owner]

\begin{tabular}{|c|c|c|c|c|c|}
\hline Year & $\begin{array}{l}\text { Ore } \\
\text { (tons) }\end{array}$ & $\begin{array}{c}\text { Gold } \\
\text { (ounces) }\end{array}$ & $\begin{array}{c}\text { Silver } \\
\text { (ounces) }\end{array}$ & $\begin{array}{c}\text { Copper } \\
\text { (pounds) }\end{array}$ & $\begin{array}{c}\text { Lead } \\
\text { (pounds) }\end{array}$ \\
\hline $\begin{array}{l}945 \\
946 \\
947\end{array}$ & $\begin{array}{r}464 \\
52 \\
47\end{array}$ & $\begin{array}{r}40 \\
7 \\
5\end{array}$ & $\begin{array}{r}3,410 \\
540 \\
488\end{array}$ & $\begin{array}{l}590 \\
236 \\
114\end{array}$ & $\begin{array}{r}27,866 \\
5,182 \\
4,152\end{array}$ \\
\hline
\end{tabular}

SIOUX GROUP (29)

The Sioux group of three claims is about $1 \frac{1}{3}$ miles east of Galena and half a mile north of the Butte mine in the NW1/4 sec. 14, T. 31 N., R. 43 E. The workings consist of two adits on the south side of Galena Canyon that were driven on the north extension of the Butte fault which here cuts chert and shale of the Scott Canyon Formation. As little exploratory work has been done since Hill (1915, p. 84) visited the property in 1912 , the following is quoted from his account.

The vein occupies a fracture zone in nearly black siliceous shales which strike N. $15^{\circ} \mathrm{W}$. and dips on the average $75^{\circ} \mathrm{W}$. In the lower tunnel, 200 feet long, the vein is about 4 feet wide, and in the 120-foot upper tunnel it ranges from 4 to 6 feet in width. The filling is largely crushed black shale containing irregular stringers and bunches of white quartz carrying pyrite. The crushed rock carries irregular masses of sulphides, largely dark sphalerite with some pyrite and possibly tetrahedrite.

There is no record of shipments from the Sioux workings. 


\section{COPPER BASIN AREA}

The Copper Basin area (pl. 3) includes the area that lies west of Elephant Head and includes Long Canyon and Licking Creek valleys and adjacent areas. The mines are known principally for their production of copper ore, but several properties have had notable silver, arsenic, lead, and zinc production. For convenience, properties north and east of Copper Basin also will be described with the Copper Basin mines.

\section{HISTORY AND PRODUCTION}

The earliest discovery in the Copper Basin area is not known, but Whitehill (1873, p. 31) mentions copper ores occurring east of the Litile Giant mine as early as 1869. In the following years any shipments made were probably combined with shipments from Copper Canyon, as no separate production was recorded until 1897 when the Glasgow \& Western Exploration Co., Ltd., consolidated the properties in the area. This company patented 27 claims in Copper Basin and began shipments to the smelter at Golconda, Nevada, from Copper Basin (pl. 14). In 1901 a churn-drilling program was started, and eight holes were put down. In 1914 the Battle Mountain Exploration Co. acquired the property and continued churn drilling; in 1916 a lessee, Frank Paul, shipped 5,000 tons of ore from the Sweet Marie glory hole. The Copper Canyon Mining Co. took over the property in August 1917 and began active exploration. By January 1, 1924, 18,665 feet of underground work had been completed, and 75 churn drill holes having an aggregate footage of 16,606 feet had been drilled. Plans were well advanced for installation of a mill, but copper prices declined and operations were suspended. During the late 1920 's, copper prices improved and lessees began shipments. From 1927 to 1936, 27,425 tons averaging 11.5 percent copper were shipped. Operations were accelerated in 1937, and during the remainder of the 1930's shipments remained at a high level, but the grade dropped considerably. The International Smelting and Refining Co. took over the Copper Canyon Mining Co. properties in 1941 and began exploratory drilling in Copper Basin; 26 diamond drill holes were put down, mainly in the vicinity of known deposits. On December 1, 1945, the property reverted to the Copper Canyon Mining Co. Shipments by lessees continued at a moderate rate until 1949 when the tonnage shipped declined markedly because of a market drop. In 1954, as copper prices again started up, shipments were resumed at several properties. The available production figures are summarized in table 7. In 1959 the Copper Basin properties of the Copper Canyon Mining Co. were purchased by the American Smelting and Refining Co., and in 1961 were taken over by the Duval Co.
TABLE 7.-Production of gold, silver, copper, and turquoise, Copper Basin 1916-53

[Figures furnished by Copper Canyon Mining Co.; published with permission]

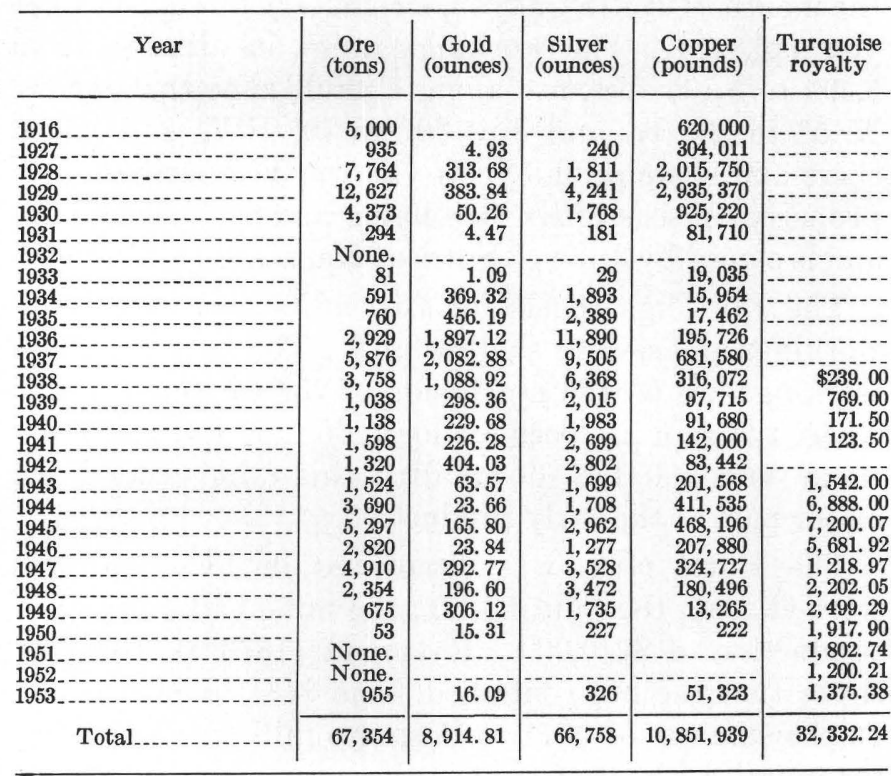

The property consists of 27 patented claims, 28 unpatented claims, and 7 placer claims (pl. 14). The main producers are the Sweet Marie, Carissa, Contention, Copper King, and Chase copper mines, and the Blue Gem Turquoise mine.

GEOLOGY

Copper Basin is underlain by rocks ranging in age from Cambrian to Quaternary ( $\mathrm{pl}$. 3). The oldest unit is the Harmony Formation of Late Cambrian age. In this area it is composed of interbedded sandstone, shale, and limestone; it has been folded locally, but most of the dips noted were steeply eastward. The Harmony Formation is overlain unconformably by conglomerate of the Battle Formation which is exposed in scattered outcrops in the southern part of Copper Basin and in a narrow belt in the northern part. The Battle Formation dips gently eastward. It is overlain disconformably by the Antler Peak Limestone in the northern and eastern parts of the area. The limestone also dips gently eastward and northeastward. On Elephant Head and on the ridges to the north the limestone is capped by quartz latite which also dips eastward. Fan gravels of Quaternary age overlap the older rocks on the north, east, and south sides of the basin area and extend up some of the valleys.

The pre-Tertiary sedimentary rocks have been cut by intrusive quartz monzonite porphyry bodies which are in the form of dikes, sills, and stock-like bodies. In the western part of Copper Basin, the quartz monozonite is the dominant rock type and occupies a belt about 2 miles wide. The sedimentary rocks have been metamorphosed adjacent to the intrusive bodies. In the 
Harmony Formation the sandstone has been metamorphosed to quartzite, the shale to biotite hornfels, and the limestone to tactite and marble. The Antler Peak Limestone is likewise metamorphosed to tactite and is recrystallized near intrusive bodies. The conglomerate of the Battle Formation was converted to quartzite conglomerate along intrusive boundaries.

The rocks in Copper Basin have been complexly faulted. The faults strike northward, northeastward, and northwestward. Most of them dip steeply and are normal or reverse faults, but some have gentle dips and are believed to be thrust faults. The thrust faults are not well exposed; as they are older, they have been cut and displaced by the younger normal faults and are therefore difficult to trace.

\section{ORE DEPOSITS}

The primary ore deposits in the Copper Basin area are of two types: copper ore deposits and gold-copper ore deposits. The copper deposits, such as the Contention, Sweet Marie, and Chase mines, have been the most productive, but the gold-copper deposits, as the Carissa and Surprise mines, contained ore bodies of fair size and grade. Secondary deposits include bodies containing chalcocite, locally oxidized to cuprite, in the enriched zone; and bodies containing azurite, malachite, chrysocolla, and copper sulfates in the oxidized zone. The copper ores in Copper Basin are commonly mixtures of primary and secondary minerals and cannot be handled by any single treatment. Some of the copper is water soluble (copper sulfates), some is acid soluble (copper carbonates), and some responds best to flotation (sulfides). R. H. Raring, General Manager, Copper Canyon Mining Co., proposed that the ore be treated by first crushing the material, then putting it through a desliming wash with the washed sands going to the grinding circuit and thence to the flotation circuit; the acidic wash water would be combined with flotation tailings at a leaching plant. $\mathrm{He}$ estimates that about 90 percent of the contained copper could be recovered in such a plant.

\section{Sweet Marie mine (72)}

The Sweet Marie mine is in the central part of the Copper Basin area on the line between secs. 32 and 33, T. 32 N., R. 44 E. The workings are on the Sweet Marie claim and the overlapping Eagle and Logan claims. Production from the Sweet Marie workings has probably been greater than all the other mines in the Copper Basin area. The early production was not accurately recorded, but much of the oxidized ore mined during the early days came from the open pit. Prior to 1929 detailed records were not kept, but production is estimated to be about 12,000 tons of ore averaging 13 percent copper. There was little activity between 1930 and 1943, but in 1944 shipments were resumed by lessees and continued through 1948; they were again interrupted until 1953 when shipments were resumed. The available production is listed in the following table:

Production of gold, silver, and copper, sweet Marie mine,

[Furnished by Copper Canyon Mining Co.; published with permission]

\begin{tabular}{|c|c|c|c|c|c|}
\hline Year & $\begin{array}{l}\text { Ore } \\
\text { (tons) }\end{array}$ & $\begin{array}{c}\text { Gold } \\
\text { (ounce } \\
\text { per ton) }\end{array}$ & $\begin{array}{c}\text { Silver } \\
\text { (ounce } \\
\text { per ton) }\end{array}$ & $\begin{array}{c}\text { Copper } \\
\text { (percent) }\end{array}$ & $\begin{array}{c}\text { Smelter } \\
\text { value }\end{array}$ \\
\hline $\begin{array}{l}1929 \text { and prior years } \\
1930 \\
1939- \\
1990 \\
1943 \\
1944 \\
1946 \\
1946 \\
1948 \\
1953\end{array}$ & $\begin{array}{r}12,000 \\
535.5 \\
48.0 \\
18.9 \\
643.5 \\
2,338.7 \\
2,370.6 \\
2,115.9 \\
1,774.1 \\
506.1 \\
647.9 \\
38.9\end{array}$ & $\begin{array}{l}0.005 \\
.008 \\
.007 \\
.006 \\
.008 \\
.008 \\
.005 \\
.006 \\
.005 \\
.005 \\
.005\end{array}$ & $\begin{array}{l}0.20 \\
.25 \\
.35 \\
.35 \\
.26 \\
.28 \\
.27 \\
.26 \\
.29 \\
.22 \\
.28 \\
.35\end{array}$ & $\begin{array}{r}13.00 \\
9.53 \\
10.84 \\
11.75 \\
7.92 \\
5.86 \\
5.45 \\
3.32 \\
3.96 \\
6.49 \\
2.44 \\
4.29 \\
\end{array}$ & $\begin{array}{r}1 \$ 351,000.00 \\
10,094.90 \\
940.97 \\
395.66 \\
8,499.76 \\
22,612.85 \\
21,016.22 \\
12,541.32 \\
22,423.32 \\
11,315.05 \\
6,578.60 \\
774.75 \\
\end{array}$ \\
\hline Total or average.. & $23,038.1$ & 0.006 & 0.27 & 9.22 & $468,193.40$ \\
\hline
\end{tabular}

1 Estimated.

The Sweet Marie workings are the most extensive in th area (pl. 15). The workings are accessible from a vertical shaft 220 feet deep from which four levels, the north sublevel, the 5,295 sublevel, the main level, and the 220 level have been run. The most extensive workings are on the main level where a block 850 feet long and as much as 350 feet wide has been explored. The workings are in shale, partly metamorphosed to hornfels, sandstone, and shaly sandstone which have been intruded by dikes, sills, and irregularly shaped intrusions of quartz monzonite porphyry. The ore is chiefly in the porphyry and shaly beds.

In the upper workings the ore was mainly the copper carbonates, malachite and azurite, and the silicate chrysocolla, but on the lower levels it was chiefly chalcocite. The largest ore body thus far discovered was about 245 feet long, 110 feet wide, and averaged 50 feet in thickness. The tenor of the ore throughout this body averaged about 3 percent copper. Much of the easily accessible higher-grade ore has been stoped, and lower-grade material has been left.

The rocks in the workings appear to have a prevailing dip eastward, but they have been locally folded. The rocks have been greatly disturbed along two major sets of faults. The northeast set strikes about N. $65^{\circ} \mathrm{E}$. and dips $25^{\circ}$ to $45^{\circ} \mathrm{NW}$. The Sweet Marie fault belongs to this set which appears to be the oldest group in the district. This set is generally cut by the other major set, the northwest set of faults that strike N. $60^{\circ}$ to $70^{\circ} \mathrm{W}$. and dip steeply southwestward or northeastward. Other faults, parallel in strike to the northeast set, are present which dip to the southeast; these faults 
also appear to be older than the northwest set and were possibly formed at the same time as the northeast set. Copper King mine (76)

The Copper King mine is on the Copper King and Copper Queen claims in the north-central part of the Copper Basin area. The workings are about a third of a mile northeast of the Carissa mine. The property has been worked since 1936 and has the following production:

Production of gold, silver, and copper, Copper King mine, 1936-54

[Furnished by Copper Canyon Mining Co.; published with permission. The overall grade of the ore has averaged less in both gold and copper than the Carissa ore, but is consistently higher in silver]

\begin{tabular}{|c|c|c|c|c|c|}
\hline Year & $\begin{array}{c}\text { Ore } \\
\text { (tons) }\end{array}$ & $\begin{array}{c}\text { Gold } \\
\text { (ounce } \\
\text { per ton) }\end{array}$ & $\begin{array}{c}\text { Silver } \\
\text { (ounces } \\
\text { per ton) }\end{array}$ & $\begin{array}{l}\text { Copper } \\
\text { (percent) }\end{array}$ & Value \\
\hline 1936 & $1,048.5$ & 0.509 & 5. 08 & 0.24 & $\$ 20,665.12$ \\
\hline & & .396 & 2.93 & 2.66 & $8,980.81$ \\
\hline & 649.2 & .460 & 3.11 & 3.78 & $13,280.67$ \\
\hline 1939 & 596.3 & .355 & 2.75 & 3.03 & $9,872.04$ \\
\hline 1940 & 479. 2 & .249 & 2.89 & 3. 18 & $7,012.24$ \\
\hline 1941 & 383.9 & .224 & 1.89 & 2.98 & $4,694.18$ \\
\hline 1943 & 454.3 & .124 & 2.19 & 3. 61 & $4,721.76$ \\
\hline 1944 & 307.3 & .040 & 2. 21 & 3. 67 & $2,611.01$ \\
\hline & 571.4 & .076 & 2. 29 & 3. 05 & $4,689.11$ \\
\hline 1946 & 99.5 & .045 & 3. 09 & 5.48 & $1,513.71$ \\
\hline 1947 & 776.9 & .142 & 1.96 & 2.96 & \\
\hline 1948 & & .340 & 5.34 & .52 & $8,908.46$ \\
\hline 1949 - & 304.5 & .326 & 4. 22 & .86 & $4,697.48$ \\
\hline $\begin{array}{l}1950 \\
1054\end{array}$ & 52.8 & .290 & 4. 30 & .81 & 663.66 \\
\hline 1954 & 314.9 & .088 & 3. 00 & 8.66 & $14,988.78$ \\
\hline Total or average & $7,045,4$ & 0.281 & 3. 21 & 2,64 & 117.331 .46 \\
\hline
\end{tabular}

The workings comprise the Copper King adit, 590 feet long, connecting drifts and crosscuts, and several shallow pits. At the north end of the workings, a surface stope and the Funduck workings explore the continuation of the Copper King ore zone.

The Copper King workings are in shale, shaly limestone, sandy limestone, and sandstone of the Harmony Formation (pl. 15). In the mine area these beds strike N. $15^{\circ}$ to $25^{\circ} \mathrm{E}$. and dip steeply southeastward. Locally they are contorted and folded, and minor folds pitch northeastward. The shaly and calcareous beds are in places metamorphosed to hornfels and calcareous hornfels, but subsequent hydrothermal and supergene alteration has changed these rocks to light-colored clayey rocks. Commonly the gold assays are highest in the shaly beds, and the copper assays are highest in the calcareous beds. The beds of the Harmony Formation are overlain unconformably by conglomerate of the Battle Formation in the workings to the northeast.

Generally the workings either extend along the strike of the beds or are parallel to the Copper King fault which trends north and dips steeply eastward and cuts diagonally across the strike of the beds. The principal stope was west of the fault in shaly beds on the footwall side; to the north these beds wedged out against the fault, and ore found along the fault on to the north was in limy layers below the shaly layers and contained less gold and a higher percentage of copper. To the south the shaly layers were cut off by faults striking northeastward and dipping steeply northwestward, thus limiting the extent of the ore on and above the adit level. The continuation of the shaly layers might be sought in the hanging wall of the Copper King fault, but the displacement on the fault is not known.

The stope north of the main workings followed the base of the Battle conglomerate which here rests on coarse sandstone of the Harmony Formation for about 200 feet. It is reported that about 250 tons of ore containing 0.12 to 0.18 ounce of gold to the ton were stoped from these workings, chiefly from calcareous shale below the conglomerate.

The Balch workings consist of an inclined shaft 80 feet deep (now filled below 55 feet), and levels run from the shaft at intervals. The Funduck workings on the northeast are in thin-bedded shale and calcareous shale and follow a fault zone downward which strikes northeastward and dips southeastward. On the south this fault is cut off by a fault striking northwestward and dipping steeply northeastward.

Surprise mine (77)

The Surprise mine adjoins the Copper King mine on the north. The workings consist of an adit 465 feet long at an altitude of 5,457 feet and connecting workings. The adit was originally driven as part of the requirements in patenting the Surprise claim, but the first shipments were made in 1937 . The production is as follows :

Production of gold, silver, and copper, Surprise mine, 1937-54

[Furnished by Copper Canyon Mining Co.; published with permission]

\begin{tabular}{|c|c|c|c|c|c|}
\hline Year & $\begin{array}{c}\text { Ore } \\
\text { (tons) }\end{array}$ & $\begin{array}{c}\text { Gold } \\
\text { (ounce } \\
\text { per ton) }\end{array}$ & $\begin{array}{l}\text { Silver } \\
\text { (ounces } \\
\text { per ton) }\end{array}$ & $\begin{array}{l}\text { Copper } \\
\text { (percent) }\end{array}$ & Value \\
\hline 1938 & $\begin{array}{r}91.9 \\
165.3 \\
98.4 \\
161.3 \\
322.3 \\
53.8\end{array}$ & $\begin{array}{r}0.237 \\
.182 \\
.198 \\
.135 \\
.136 \\
.123\end{array}$ & $\begin{array}{l}2.52 \\
1.66 \\
1.80 \\
1.29 \\
1.32 \\
1.38\end{array}$ & $\begin{array}{l}2.74 \\
1.92 \\
1.64 \\
1.57 \\
1.77 \\
1.44\end{array}$ & $\begin{array}{r}\$ 1,126.93 \\
1,373.67 \\
872.51 \\
1,098.42 \\
3,142.01 \\
519.55\end{array}$ \\
\hline Total or average & 893.0 & 0.161 & 1.56 & 1.82 & $8,133.09$ \\
\hline
\end{tabular}

The Surprise adit is in the Antler Peak Limestone from the portal for a distance of 60 feet and then is in conglomerate of the Battle Formation for the next 255 feet; at this point a fault that strikes northwestward is crossed, and beyond the fault the rock is calcareous shale and sandstone of the Harmony Formation (pl. 15).

The principal stopes are in the area from 320 to 370 feet from the portal. The enclosing rock was originally calc-silicate rock, which is now partly altered to iron oxides, clay minerals, and secondary copper minerals. 
Carissa mine (73)

The Carissa mine is 1,800 feet north of the Sweet Marie mine on the Carissa and Pedro claims in the SE1/4 sec. 29 , and SW $1 / 4$ sec. 28 , T. 31 N., R. 44 E. The property is credited with a small production of oxidized copper ore prior to 1930, but its period of major productivity dates from 1936 when Horace Dolezal and Ernest Johnson discovered high-grade gold ore in an open cut. The Carissa mine is second among Copper Basin mines in total production, and it leads in production of gold. The recorded production follows:

Production of gold, silver, and copper, Carissa mine, 1936-54

[Furnished by Copper Canyon Mining Co.; published with permission]

\begin{tabular}{|c|c|c|c|c|c|}
\hline Year & $\begin{array}{c}\text { Ore } \\
\text { (tons) }\end{array}$ & $\begin{array}{c}\text { Gold } \\
\text { (ounce } \\
\text { per ton) }\end{array}$ & $\begin{array}{c}\text { Silver } \\
\text { (ounces } \\
\text { per ton) }\end{array}$ & $\begin{array}{c}\text { Copper } \\
\text { (percent) }\end{array}$ & Value \\
\hline $\begin{array}{l}1936 \\
1937 \\
1938 \\
1939- \\
1940 \\
1945- \\
1947- \\
1948 \\
1949- \\
1953- \\
1954\end{array}$ & $\begin{array}{r}1,880.6 \\
2,980.4 \\
2,178.3 \\
88.3 \\
239.8 \\
429.8 \\
693.8 \\
48.2 \\
370.8 \\
118.3 \\
77.0\end{array}$ & $\begin{array}{r}0.725 \\
.622 \\
.343 \\
.905 \\
.433 \\
.176 \\
.149 \\
.007 \\
.558 \\
.085 \\
.007\end{array}$ & $\begin{array}{r}3.49 \\
2.44 \\
1.76 \\
2.40 \\
1.94 \\
.68 \\
.63 \\
.33 \\
1.22 \\
.48 \\
.40\end{array}$ & $\begin{array}{l}5.07 \\
2.56 \\
2.84 \\
.83 \\
1.93 \\
1.35 \\
1.83 \\
3.06 \\
1.08 \\
2.78 \\
4.40\end{array}$ & $\begin{array}{r}\$ 59,564.70 \\
75,873.93 \\
31,730.28 \\
2,667.16 \\
3,947.38 \\
3,030.88 \\
6,819.01 \\
450.56 \\
7,309.83 \\
1,128.94 \\
1,537.07\end{array}$ \\
\hline Total or average.... & $9,104.3$ & 0.499 & 2.15 & 2.96 & $194,059.74$ \\
\hline
\end{tabular}

The mine workings consist of a glory hole and connecting haulage ways, called the Main adit and the East adit, and level workings from the J-D shaft (pl. 15). These workings are principally in shale, calcareous shale, and limestone of the Harmony Formation which were metamorphosed to hornfels, calcareous hornfels, and tactite. The East adit and some surface workings also show quartzite of the Harmony Formation and quartzite conglomerate of the Battle Formation which in this area overlies the older rocks. The conglomerate is exposed in the workings only near the face of the East adit where it is in contact with garnet hornfels in the hanging wall of the Elvira fault.

The greater part of the gold ore mined came from the glory hole where ore was stoped down dip in hornfels for a length of 150 feet, for a width as much as 60 feet, and for a thickness of 4 to 15 feet. The ore was soft, green to brown altered hornfels and tactite containing copper carbonates and iron oxide. The unaltered ore contains pyrite, chalcopyrite, and pyrrhotite in a gangue of lime-silicate minerals including epidote, diopside, and garnet, accompanied by quartz and calcite. Upon oxidation, the pyrite and pyrrhotite changed to iron oxides; the chalcopyrite was altered, part of the copper remained in place as copper carbonates, and part was transported downward and deposited below as chalcocite or cuprite. Scheelite occurs as scattered grains and in sporadic pockets in the tactite.

The glory hole stope followed bedding in the Har- mony Formation; evidently, the ore replaced certain favorable beds of hornfels or calcareous hornfels. No apparent structural control of the ore can be seen, but a porphyry dike on the northwest side of the glory hole roughly parallels the ore shoot. On the southeast, the ore graded into barren hornfels. A drill hole showed only barren material up dip on the southwest side of the glory hole. Down dip on the northeast, the ore ended against the $J-D$ fault. As this fault is probably a normal fault, any northeastward continuation of the ore has probably been eroded. At depth, the drill hole passed through altered argillaceous rocks, hornfels, and porphyry, gradually passing into grit and shaly grit below the workings. No encouraging signs of mineralization were reported in the drill hole.

On the 5509 level, about 56 feet below the collar of the $J-\mathrm{D}$ shaft, exploratory work was done to explore the $J-D$ fault at depth and to test the hanging wall zone of the fault to the south. Except for small pockets of cuprite on the J-D fault, the exploratory work was not encouraging. In the crosscut about 50 feet south of the shaft and in the crosscut northeast of the shaft, lowangle shears are exposed. A pebble dike cut in drill hole No. 19 at a depth of 200 feet may be on a similar structure.

Ore has been stoped from the East adit area, and an open pit has been dug from the present site of the portal southward to the J-D fault zone. The ore here was presumably a continuation of the ore zone mined in the glory hole.

\section{Contention mine (66)}

The Contention mine is about 1,200 feet northwest of the Chase and Pedro mines on the Contention No. 1 claim. It ranks third in production in the Copper Basin area after the Sweet Marie and Carissa mines. The records of shipments prior to 1927 are not available; since 1927 the production is as follows:

Production of gold, silver, and copper, Contention mine, 1927-54

[Furnished by Copper Canyon Mining Co.; published with permission]

\begin{tabular}{|c|c|c|c|c|c|}
\hline Year & $\begin{array}{l}\text { Ore } \\
\text { (tons) }\end{array}$ & $\begin{array}{c}\text { Gold } \\
\text { (ounce } \\
\text { per ton) }\end{array}$ & $\begin{array}{c}\text { Silver } \\
\text { (ounce } \\
\text { per ton) }\end{array}$ & $\begin{array}{c}\text { Copper } \\
\text { (percent) }\end{array}$ & Value \\
\hline $\begin{array}{l}1927 \\
1928 \\
1937 \\
1938 \\
1939040 \\
1941 \\
1944 \\
19483\end{array}$ & $\begin{array}{r}84.8 \\
1,590.2 \\
507.4 \\
1,018.0 \\
550.4 \\
305.7 \\
385.1 \\
11.6 \\
141.8 \\
162.5 \\
752.3 \\
382.1 \\
969.6 \\
818.4 \\
21.3 \\
277.1 \\
\end{array}$ & $\begin{array}{l}0.008 \\
.006 \\
.008 \\
.015 \\
.012 \\
.021 \\
.016 \\
.010 \\
.009 \\
.005 \\
.020 \\
.005 \\
.023 \\
.005 \\
.005 \\
.005 \\
\end{array}$ & $\begin{array}{l}0.32 \\
.30 \\
.60 \\
.36 \\
.34 \\
.48 \\
.30 \\
.30 \\
.34 \\
.24 \\
.28 \\
.25 \\
.52 \\
.31 \\
.40 \\
.41 \\
\end{array}$ & $\begin{aligned} 16.55 \\
12.81 \\
9.25 \\
7.28 \\
7.74 \\
8.13 \\
5.64 \\
4.91 \\
8.38 \\
7.21 \\
4.79 \\
5.03 \\
3.70 \\
4.29 \\
4.37 \\
4.55 \\
\end{aligned}$ & $\begin{array}{r}\$ 3,028.33 \\
42,971.97 \\
13,049.93 \\
13,573.82 \\
6,029.62 \\
3,987.82 \\
3,343.75 \\
859.51 \\
1,993.76 \\
1,973.48 \\
5,778.44 \\
4,066.59 \\
12,078.80 \\
11,283.87 \\
406.85 \\
5,905.63 \\
\end{array}$ \\
\hline Total or average..... & $8,078.3$ & 0.011 & 0.36 & 7.38 & $130,332.17$ \\
\hline
\end{tabular}


The shipments made in 1927 and 1928 are notable for their high copper content. Since then, the grade has declined more or less gradually.

The workings are on two principal levels; the 130 level which is reached by the Contention shaft, and the sub-level workings accessible from the 130 level by raises and from the glory hole west of the Contention shaft.

The workings are in quartz monzonite porphyry and in hornfels and sandstone of the Harmony Formation which in this area is folded, but at most places appears to dip at moderate angles eastward. The shale is largely metamorphosed to hornfels, but throughout the mine hydrothermal and supergene alteration have masked the metamorphism; generally, the hornfels is leached and argillized. Pebble dikes containing fragments of quartz monzonite and argillite in a matrix of crushed argillite were noted on the 130 level (fig. 19). It is

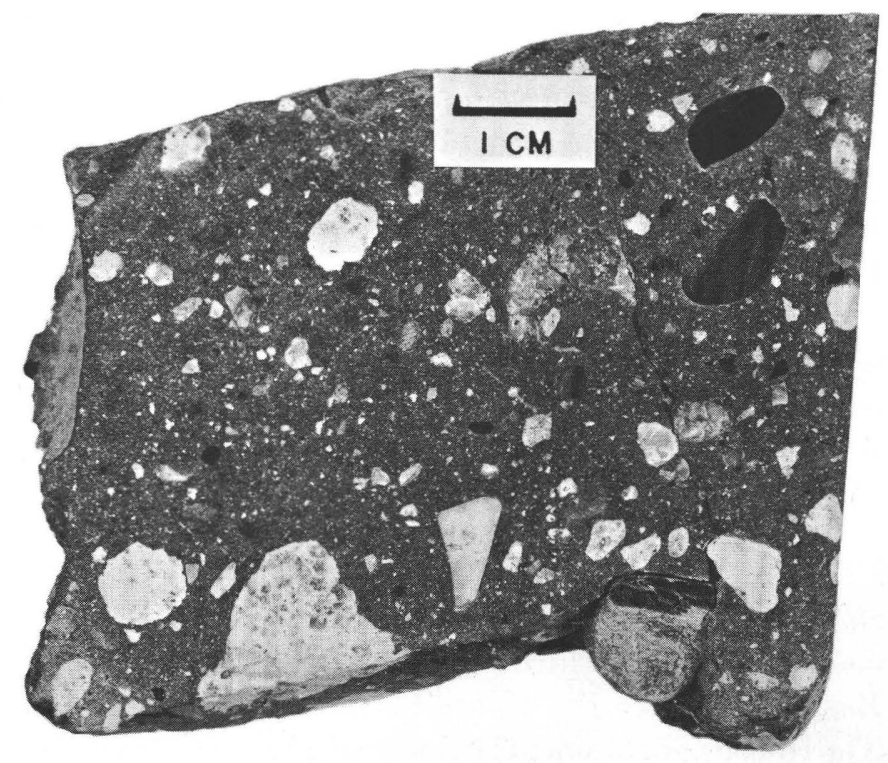

Figure 19.-Pebble dike, Contention mine. The white fragments are quartz monzonite porphyry set in a groundmass of comminuted black argillite.

inferred that the argillite is derived from the Scott Canyon Formation that underlies the Dewitt thrust in this area.

These rocks have been broken and displaced by faults; the principal fault is the Contention fault which strikes about N. $60^{\circ}$ to $80^{\circ}$ E. and dips $20^{\circ}$ to $30^{\circ} \mathrm{NW}$. A parallel fault, the Dewitt normal fault, dips on the average about $65^{\circ} \mathrm{NW}$, but in places its dip is as low as $50^{\circ}$ and as steep as $75^{\circ}$. The Dewitt normal fault cuts the Kelly and Middleton faults which strike N. $60^{\circ}$ $\mathrm{W}$.; the Middleton fault dips $20^{\circ}$ to $35^{\circ} \mathrm{NE}$, and the Kelly fault dips $35^{\circ}$ to $50^{\circ} \mathrm{NE}$. The ore bodies are found along these faults and in the adjacent rock. The Contention fault, which is exposed in the shaft and in the southern part of the workings, bounds the commercial ore, and no ore has been shipped from rocks on its footwall side. The principal ore bodies are along the Kelly, Dewitt (normal), and Middleton faults between the surface and the 130 level, but there is considerable stoping also on the 130 level in the northeastern part of the workings along these faults.

The principal stopes are the open stope and the connecting glory hole stope which yielded carbonate ore adjacent to the Dewitt normal fault in the footwall of the Kelly fault. The wallrock is altered hornfels, now highly argillized, containing malachite, azurite, and chrysocolla together with a little chalcocite. The carbonate ore probably formed from a supergene ore body-largely chalcocite - during oxidation. The ore continued downward slightly below the sublevel $(5,578$ foot level), but most of it was too low grade to ship, as it ranged from 2.58 to 3.03 percent copper.

Other shipments were made from the Middleton stopes in the northern part of the mine, chiefly between the sublevel and the 130 level. The ore was between the Kelly and Middleton faults on the hanging wall of the Dewitt normal fault. Stopes in this area were not accessible in 1947.

Work was being carried on in 1947 just above the 130 level near the intersections of the Kelly and Dewitt faults. The ore is composed of chalcocite in veinlets and disseminated throughout hornfels and sandstone. The ore in this stope ranged in grade from 3 to 6 percent copper.

\section{Wldow mine (71)}

The Widow mine is 800 feet south of the Sweet Marie mine on the Widow and Magpie claims in the NE1/4 sec. 32 , T. 32 N., R. 44 E. The early history is not known. Exploratory work was carried on between 1917 and 1923, but no production was recorded until 1927. The available production figures are as follows:

Production of gold, silver, and copper, Widow mine, 1927-45

[Furnished by Copper Canyon Mining Co.; published with permission]

\begin{tabular}{|c|c|c|c|c|c|}
\hline Year & $\begin{array}{c}\text { Ore } \\
\text { (tons) }\end{array}$ & $\begin{array}{c}\text { Gold } \\
\text { (ounce } \\
\text { per ton) }\end{array}$ & $\begin{array}{c}\text { Silver } \\
\text { (ounce } \\
\text { per ton) }\end{array}$ & $\begin{array}{l}\text { Copper } \\
\text { (percent) }\end{array}$ & Value \\
\hline $\begin{array}{l}1927 \\
1936 \\
1944 \\
1945\end{array}$ & $\begin{array}{l}850.1 \\
264.3 \\
183.7 \\
464.3 \\
979.4\end{array}$ & $\begin{array}{l}0.005 \\
.007 \\
.006 \\
.005 \\
.005\end{array}$ & $\begin{array}{l}0.25 \\
.20 \\
.27 \\
.25 \\
.20\end{array}$ & $\begin{array}{r}16.23 \\
7.61 \\
9.14 \\
4.41 \\
3.78\end{array}$ & $\begin{array}{r}\$ 27,715.45 \\
4,369.40 \\
2,655.76 \\
3,132.89 \\
5,538.15\end{array}$ \\
\hline Total or average... & $2,741.8$ & 0.005 & 0.23 & 8.48 & $43,411.65$ \\
\hline
\end{tabular}

The workings were inaccessible in 1953 ; they consist of a vertical shaft 200 feet deep and levels at 150 and 200 feet. According to company records, the workings explore a fault zone that strikes N. $45^{\circ} \mathrm{E}$. and dips $45^{\circ}$ to $55^{\circ} \mathrm{NW}$. in sandstone and shale of the Harmony For- 
mation. The ore is said to be similar to the ore in the Sweet Marie mine.

Chase mine (69)

The Chase mine is 900 feet northwest of the Sweet Marie mine on the Raven and Sparrow claims in the SE $1 / 4$ sec. 29 , T. 32 N., R. 44 E. The workings consist of an inclined shaft and levels at 130 and 185 feet below the collar in hornfels and sandstone of the Harmony Formation and in quartz monzonite porphyry intrusives that cut these rocks. The shaft was caved at the time of visit in 1953, and the workings were not accessible.

The production records are incomplete; it is reported that some sulfide ore was shipped between 1918 and 1923. In 1937, 3.9 tons of sulfide ore containing 31.5 percent copper was shipped. In 1948, lessees shipped several cars of ore averaging about 5 percent copper from the dumps.

According to E. S. Bastin, ${ }^{4}$ the workings follow the Chase vein which is along a fault that strikes N. $60^{\circ} \mathrm{W}$. and dips steeply northeastward to vertical. Near the surface the ore is composed mainly of copper carbonates which gradually give way to chalcocite at depth.

On the 130 level the ore is largely in the fault zone at the shaft and along a drift to the west. On the 185 level, the ore is also along the Chase fault, chiefly near the shaft.

\section{Elvira adit (75)}

The Elvira adit is west of the Copper King mine on the Elvira and Copper Queen claims at an altitude of 5,624 feet in the W1/2 sec. 28, T. 32 N., R. 44 E. (pl. 15). The adit is 350 feet long and strikes N. $25^{\circ} \mathrm{W}$. Except for a small stope a hundred feet from the portal which may have yielded a few tons of ore, there has been no production from the workings.

The first 200 feet of the adit is in thin-bedded shale and calcareous shale which have been locally metamorphosed to hornfels and garnet-diopside hornfels; these rocks strike northwest and dip to the southwest and southeast in most places, but locally stand vertical. At 150 feet from the portal, the shaly rocks grade into sandy limestone, and then 50 feet farther from the portal into massive grit containing a few shaly beds. A fault zone, 200 feet from the portal, which is made up of several shears, cuts the adit; this zone strikes northwest and dips steeply southwest. At 250 feet from the portal, another fault zone striking $\mathrm{N} .70^{\circ} \mathrm{W}$. and dipping northeastward cuts across the adit. From this point the adit is in sandstone, shale and calcareous shale; the last 70 feet cuts a dense hornblende-plagioclase rock which appears to be a dioritic rock intruded into calcareous shale. This is probably a contact facies of a down-

${ }^{4}$ Report, 1922, in files of the Copper Canyon Mining Co. ward extension of the diorite dike mapped on the ridge to the north.

Raven adit (70)

The Raven adit is on the Sparrow, Raven, and Badger claims (pl. 15). The adit is 735 feet long and trends N. $58^{\circ} \mathrm{W}$. Presumably, it was driven to explore the quartz monzonite porphyry intrusive west of the Chase mine, but only low-grade copper ore was found, and no ore has been stoped.

The adit was driven in interbedded shale and coarse sandstone of the Harmony Formation for 125 feet, and from there to the face the rock is chiefly quartz monzonite porphyry with inclusions of Harmony Formation. Most of the porphyry is altered (argillized) in varying degrees, and in places it is cut by quartz-limonite veinlets. About 400 feet from the portal, small pockets and veinlets of turquoise cut the porphyry, but as the color of the turquoise is light blue, the material is not of commercial grade at the present time. At the face of the adit, the porphyry is quite fresh and is medium gray. Henrietta and Uncle Tom mines (79, 78)

The Henrietta mine (79) (pl. 15) is in the northeast corner of the Independent claim about 2,500 feet east of the Sweet Marie shaft. The workings include a vertical shaft 60 feet deep, an inclined shaft, and connecting underground workings. The production figures are incomplete, but production since 1937 is given in the following table:

Production of gold, silver, and copper, Henrietta mine, 1987-54

[Furnished by Copper Canyon Mining Co.; published with permission]

\begin{tabular}{|c|c|c|c|c|c|}
\hline Year & $\begin{array}{c}\text { Ore } \\
\text { (tons) }\end{array}$ & $\begin{array}{c}\text { Gold } \\
\text { (ounce } \\
\text { per ton) }\end{array}$ & $\begin{array}{c}\text { Silver } \\
\text { (ounce } \\
\text { per ton) }\end{array}$ & $\begin{array}{c}\text { Copper } \\
\text { (percent) }\end{array}$ & Value \\
\hline 1937 & $\begin{array}{r}519.7 \\
214.7 \\
87.1 \\
154.3 \\
96.9 \\
367.7 \\
336.5 \\
51.4 \\
188.0\end{array}$ & $\begin{array}{l}0.010 \\
.030 \\
.024 \\
.007 \\
.005 \\
.006 \\
.005 \\
.005 \\
.005\end{array}$ & $\begin{array}{l}0.20 \\
.25 \\
.44 \\
.30 \\
.23 \\
.35 \\
.39 \\
.30 \\
.32\end{array}$ & $\begin{array}{r}20.00 \\
14.58 \\
9.06 \\
4.65 \\
3.40 \\
5.08 \\
4.23 \\
3.21 \\
3.69\end{array}$ & $\begin{array}{r}\$ 19,707.72 \\
4,478.75 \\
1,403.40 \\
1,111.51 \\
473.13 \\
6,105.33 \\
4,575.22 \\
734.09 \\
3,146.96\end{array}$ \\
\hline Total or average.- & $2,016.3$ & 0.015 & 0.33 & 9.67 & $41,736.11$ \\
\hline
\end{tabular}

The ore that has been mined is mainly chalcocite and a little malachite in hornfels of the Harmony Formation. The stopes in part followed bedding and in part followed faults. The surface stopes followed an argillite unit that dipped $40^{\circ}$ to $55^{\circ} \mathrm{SE}$. The copper ore also occurred in the fault zone striking N. $30^{\circ} \mathrm{W}$. and dipping $60^{\circ}$ to $75^{\circ} \mathrm{SW}$. that was followed downward by the inclined shaft to the 5,310 level. A drift was run 140 feet northwestward along a parallel fault 35 feet to the west, but only sparse copper and iron oxide showings were found.

Other workings on the Independent claim include an adit and several shallow pits on the northwest corner of 
the claim. These workings include an adit was driven N. $25^{\circ}$ E. for 110 feet through argillite and altered quartz monzonite; then the operators drifted N. $75^{\circ} \mathrm{W}$. and S. $75^{\circ}$ E. along a fault zone that dips $45^{\circ}$ to $77^{\circ} \mathrm{SW}$. A little copper stain - chiefly malachite - and iron oxides occur sporadically along the fault. There is no recorded production from the adit. Two open pits about 150 feet southwest of the portal were being worked on a small scale in September 1953. A few tons of pyrite and chalcocite-bearing sandstone had been sorted for shipment.

Workings near the center of the Uncle Tom claim (78) (pl. 15) include several shallow pits. Narrow veins of iron oxides, chrysocolla, malachite, and azurite which cut sandstone and shale of the Harmony Formation have yielded a small production. One of the veins contains lenses of clay minerals surrounded by chrysocolla and malachite (fig. 12B).

Pedro (Goff) mine (68)

The Pedro (Goff) workings on the Daley claim, 400 feet north of the Chase shaft, consist of a shaft 64 feet deep from which a drift has been driven 100 feet to the north. The workings are in argillized quartz monzonite porphyry and hornfels of the Harmony Formation. The production from the Pedro workings is as follows:

Production of gold, silver, and copper, Pedro mine, 1937-54

[Furnished by Copper Canyon Mining Co.; published with permission]

\begin{tabular}{|c|c|c|c|c|c|}
\hline Year & $\begin{array}{c}\text { Ore } \\
\text { (tons) }\end{array}$ & $\begin{array}{c}\text { Gold } \\
\text { (ounce } \\
\text { per ton) }\end{array}$ & $\begin{array}{c}\text { Silver } \\
\text { (ounce } \\
\text { per ton) }\end{array}$ & $\begin{array}{c}\text { Copper } \\
\text { (percent) }\end{array}$ & Value \\
\hline $\begin{array}{l}1937-190 \\
1940 \\
1948 \\
1954-19\end{array}$ & $\begin{array}{r}6.2 \\
15.4 \\
94.3 \\
52.9 \\
49.6\end{array}$ & $\begin{array}{l}0.005 \\
.006 \\
.007 \\
.002 \\
.005\end{array}$ & $\begin{array}{r}0.53 \\
.72 \\
.22 \\
.15 \\
.25\end{array}$ & $\begin{array}{r}8.42 \\
12.13 \\
3.98 \\
2.14 \\
2.51\end{array}$ & $\begin{array}{r}\$ 107.60 \\
307.78 \\
1,197.30 \\
455.95 \\
525.80\end{array}$ \\
\hline Total or average.....-.- & 218.4 & 0.006 & 0.25 & 3. 88 & $2,594.43$ \\
\hline
\end{tabular}

Chalcocite, pyrite, and malachite were noted on faults that trend northward, northeastward, and northwestward. A pebble dike 6 to 10 inches wide cuts northward across the other faults at the face.

Blue Gem Turquoise mine (67)

In 1918 turquoise was discovered on the Pedro claim which is on the slope east of the Contention mine (pl. 15). The showings were first explored by the American Gem Co. of Los Angeles in 1937, and 424 pounds of gem turquoise valued at $\$ 8,480$ was produced in that year. Subsequently, Lee Hand and Alvin Layton leased the property and operated it until 1953 when the lease was sold to the King Bros. of Albuquerque, N. Mex.

The workings are in biotite hornfels and quartzite of the Harmony Formation which strike northward and $\operatorname{dip} 20^{\circ}$ to $50^{\circ} \mathrm{E}$. in the mine area. The turquoise fills veinlets a fraction of an inch to 4 inches wide, mainly in the hornfels. The higher grade turquoise is commonly in narrow veinlets from $1 / 16$ to $1 / 2$ inch wide. It is removed from the enclosing rock by hand cobbing or sawing.

The principal turquoise body extended with fair continuity down dip for 180 feet and along strike for more than 120 feet (pl. 15). Throughout most of the mine area 6 to 8 feet of turquoise-bearing rock was stoped; pillars left in the workings show that the turquoise veins are irregularly distributed in the fractured rock (fig. $13 A$ ). Associated with the turquoise are veins and pods of clay minerals, mainly montmorillonite, kaolinite, and richellite, and abundant jarosite and limonite (fig. 14). It is inferred that this mineral assemblage was formed by acid supergene solutions derived from the oxidation of pyrite.

\section{Empire mine (81)}

The Empire mine is 2,500 feet southeast of the Sweet Marie mine, on the Empire claim. It is reported that shipments of copper ore were made from this property during the early days of the camp, and a few tons of sorted ore from the dumps were shipped about 1918.

The principal opening is an inclined shaft in siliceous shale of the Harmony Formation; the shaft, now caved, was reported to be 300 feet deep. The ore mined came from the shaft, but nothing is known of the size and grade of the ore body.

\section{Northern Light (80)}

The Northern Light workings are on the Northern Light claim, 3,000 feet east of the Sweet Marie shaft. Shipments made from this property are reported to have contained 12 to 13 percent copper, but the tonnage is not known.

The workings consist of several shallow pits, short adits, and open cuts. These workings are, for the most part, now caved and inaccessible. Iron-stained shale, calcareous shale, and shaly grit outcrop near the workings.

\section{Copperopolis adit (65)}

The Copperopolis adit (pl. 15), which was driven S. $75^{\circ} \mathrm{W}$. on the Copperopolis claim, was open for a length of 425 feet at the time of visit in December 1953. The adit is in altered hornfels and sandstone of the Harmony Formation; these rocks are locally contorted, but mostly dip steeply eastward. Near the portal, the argillite is silicified and iron-strained; from a point 160 feet from the portal to the face the argillite is pyritized. The adit is caved 425 feet from the portal where a fault that strikes northwestward and dips $30^{\circ}$ to $50^{\circ} \mathrm{SW}$. crosses the drift. This fault may be a thrust faultpossibly one of the faults that passes through the Contention mine. 
Crown Point Extension claim (74)

The workings on the Crown Point Extension claim consist of caved pits and an adit 105 feet long that strikes $\mathrm{S} .82^{\circ} \mathrm{W}$. The adit is in leached and iron-stained quartz monzonite porphyry from the portal to about 60 feet. From this point to the face, it is in altered hornfels which is cut by pebble dikes as much as 4 feet wide. The dikes contain fragments of black chert and argillite that apparently were derived from the Scott Canyon Formation. Except for a little iron oxide, no signs of mineralization were noted in the adit; it is reported that small copper bodies were mined from the surface pits.

Copper Prize (Copper Pick) mine (82)

The Copper Prize property, also known as the Copper Pick or Mesa Copper, is in the NE1/4 sec. 33, T. $32 \mathrm{~N}$., R. 44 E., about half a mile south of Elephant Head. The property consists of seven claims that are owned by Nellie G. Adams of Battle Mountain, Nev.

The workings (pl. 16) are in feldspathic sandstone and shale of the Harmony Formation, which strike northeastward and dip steeply southeastward. Quartz monzonite porphyry dikes cut the sandstone and shale in places. These rocks are broken by faults that mainly strike northeastward and dip southeastward and northwestward.

The workings, which are mainly on the Copper Prize Nos. 1 and 2 claims, consist of two adits, one 330 feet long and one 150 feet long, two shafts, and several open cuts. The 330-foot adit on Copper Prize No. 1 claim was driven to explore showings of malachite and chrysocolla that were discovered on the surface along a fault zone striking N. $50^{\circ}$ to $60^{\circ}$ E. and dipping $40^{\circ}$ to $50^{\circ} \mathrm{SE}$. Evidently the showings pinched just below the open cut as the fault zone in the adit is barren. A fault zone 140 feet from the portal that strikes N. $35^{\circ}$ E. and dips $75^{\circ} \mathrm{NW}$. contains a pocket of copper carbonates, pyrite, and chalcopyrite. A winze was sunk 62 feet on these showings, but no ore was stoped. The fault zones cut in the remainder of the adit were barren except for a little iron oxide stain.

The 150-foot adit on the Copper Prize No. 2 claim is in limestone and argillite that strike northeastward and dip northwestward for the most part. These rocks are cut by barren faults. Two shafts, one 50 feet north of the portal of the adit and one 275 feet to the north, were inaccessible in 1953. It is reported that the shafts yielded a small production of good grade copper ore.

Peggy group (62a)

The Peggy group of four unpatented claims is part of the holdings of Gordon Estes and associates of Battle Mountain. The property was first located by Jasper Vail in 1916 and has been worked intermittently by lessees (Vanderburg, 1939, p. 30). The production recorded by the U.S. Bureau of Mines is as follows:

Production of gold, silver, and copper, Peggy group, 1935-36

[Furnished by U.S. Bur. of Mines; published with permission of the owner]

\begin{tabular}{c|r|r|r|r}
\hline Year & $\begin{array}{r}\text { Ore } \\
\text { (tons) }\end{array}$ & $\begin{array}{c}\text { Gold } \\
\text { (ounces) }\end{array}$ & $\begin{array}{r}\text { Silver } \\
\text { (ounces) }\end{array}$ & $\begin{array}{l}\text { Copper } \\
\text { (pounds) }\end{array}$ \\
\hline 1935 & $\begin{array}{r}323 \\
29\end{array}$ & $\begin{array}{r}40.25 \\
4.00\end{array}$ & $\begin{array}{r}5,100 \\
404\end{array}$ & \\
\hline 1936 & & & \\
\hline
\end{tabular}

The workings consist of an adit 200 feet long, several shallow shafts, and surface cuts and pits along a fault zone that strikes northward and dips steeply westward in quartzite and hornfels of the Harmony Formation. Vanderburg (1939, p. 30) reports that the ore was 6 inches to 3 feet wide, and that the best ore occurred at intersections of the fault zone and cross fractures.

The ore is composed of a mixture of iron oxides, quartz, and clay minerals. A typical shipment contained 0.14 ounce of gold and 18.33 ounces of silver to the ton, 0.20 percent copper, 0.4 percent sulfur, 0.85 percent arsenic, 5.6 percent iron, 0.35 percent antimony, and 0.8 percent calcium oxide.

Bentley mine (59)

The Bentley mine is near the head of the north fork of Licking Creek in the NW1/4 sec. 30, T. 32 N., R. 44 E. The mine was located by Mr. Bentley about 1900 . S. F. Paul and Frank Keever operated the property in 1923 and 1924, and control later passed to Keever who held it until 1954 when it was sold to Leon Belaustegui of Battle Mountain. The property includes eight claims. The recorded production is summarized as follows:

Production of gold, silver, copper, and lead, Bentley mine,

[Furnished by the U.S. Bur. of Mines; published with permission of the owner]

\begin{tabular}{|c|c|c|c|c|c|}
\hline Year & $\begin{array}{c}\text { Ore } \\
\text { (tons) }\end{array}$ & $\begin{array}{c}\text { Gold } \\
\text { (ounces) }\end{array}$ & $\begin{array}{c}\text { Silver } \\
\text { (ounces) }\end{array}$ & $\begin{array}{c}\text { Copper } \\
\text { (pounds) }\end{array}$ & $\begin{array}{c}\text { Lead } \\
\text { (pounds) }\end{array}$ \\
\hline $\begin{array}{l}1923 \\
1924 \\
1940 \\
1941 \\
1949\end{array}$ & $\begin{array}{l}251 \\
20 \\
27 \\
26 \\
20 \\
25.1 \\
39.4\end{array}$ & $\begin{array}{r}53.0 \\
3.0 \\
6.0 \\
3.0 \\
2.0 \\
5.0 \\
5.0\end{array}$ & $\begin{array}{r}4,125 \\
218 \\
616 \\
613 \\
523 \\
515 \\
807\end{array}$ & $\begin{array}{r}1,094 \\
140 \\
113 \\
100 \\
99\end{array}$ & $\begin{array}{r}17,952 \\
1,920 \\
2,528 \\
1,939 \\
2,381 \\
3,800 \\
5,781\end{array}$ \\
\hline
\end{tabular}

The mine workings consist of two adits, one 650 feet long and the other 250 feet long. A winze 130 feet deep was put down along the fault in the west adit, and a drift 20 feet long extends northeast from the winze 120 feet below the adit level. Small stopes extend above and below the levels in both adits.

The mine workings are in sandstone, shale, and calcareous shale of the Harmony Formation, which strikes northwestward and dips $20^{\circ}$ to $30^{\circ} \mathrm{NE}$. in the mine area, The sedimentary rocks are cut by northeast-striking 
faults which dip $45^{\circ}$ to $80^{\circ} \mathrm{NW}$. (pl. 16). Diabasic dikes, which were cut in the mine workings, generally follow faults, though in places they cut across the faults.

The ore bodies that were mined occurred in the fault zones and consisted largely of iron oxides and secondary lead, copper, and zine minerals. The oxidized zone extended down the dip of the faults about 65 feet below the adit level. The ore bodies were narrow, ranging from a few inches to 6 feet thick and averaging about 18 inches. They ranged from 30 to 120 feet long and extended down dip as much as 55 feet.

In the sulfide zone, the ore minerals are pyrite, galena, sphalerite, and a little chalcopyrite, marcasite, and stibnite. The stibnite occurs mainly as a coating on the sphalerite. Near surface oxidation of these minerals formed ore bodies which were enriched in lead, silver, and gold.

\section{o'Leary (Buckingham) mine (57)}

The O'Leary mine properties, formerly known as the Western Nevada Mining Co. and the Buckingham Mining Co., are in the southwestern part of Copper Basin in secs. 30 and 31, T. 32 N., R. 43 E., and sec. 25, T. 32 N., R. 44 E. The property consists of 31 claims which in 1955 were owned by Mrs. Margaret O'Leary of Reno, Nev., and were under option to the $\mathrm{C} \& \mathrm{R}$ Nevada Mines Co. The mine was discovered during the late 1860's, and some of the claims were productive then, but no records of the early shipments are available. The recorded production is summarized in the following table:

Production of gold, silver, copper, lead, and zinc, O'Leary mine, 1913-29

[Furnished by the U.S. Bur. of Mines; published with permission of the owner]

\begin{tabular}{|c|c|c|c|c|c|c|}
\hline Year & $\begin{array}{c}\text { Ore } \\
\text { (tons) }\end{array}$ & $\begin{array}{c}\text { Gold } \\
\text { (ounces) }\end{array}$ & $\begin{array}{c}\text { Silver } \\
\text { (ounces) }\end{array}$ & $\begin{array}{c}\text { Copper } \\
\text { (pounds) }\end{array}$ & $\underset{\text { (pounds) }}{\text { Lead }}$ & $\begin{array}{c}\text { Zinc } \\
\text { (pounds) }\end{array}$ \\
\hline $\begin{array}{l}1913 \\
1916 \\
1917 \\
1922 \\
1925 \\
1926 \\
1927 \\
1928 \\
1929\end{array}$ & $\begin{array}{r}23 \\
13 \\
108 \\
17 \\
26 \\
11 \\
500 \\
3,000 \\
1,500\end{array}$ & $\begin{array}{r}1.41 \\
.61 \\
19.25 \\
6.0 \\
8.40 \\
.15 \\
11.43 \\
13.36 \\
6.62\end{array}$ & $\begin{array}{r}728 \\
304 \\
2,355 \\
688 \\
1,716 \\
377 \\
837 \\
15,514 \\
9,950\end{array}$ & $\begin{array}{r}390 \\
299 \\
765 \\
433 \\
151 \\
359 \\
4,063 \\
2,611\end{array}$ & $\begin{array}{r}6,269 \\
3,273 \\
7,266 \\
805 \\
3,913 \\
3,883 \\
674 \\
21,480 \\
13,182\end{array}$ & 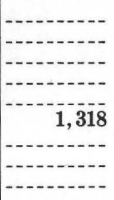 \\
\hline
\end{tabular}

The workings are mainly in quartzite and hornfels of the Harmony Formation and dikes of quartz monzonite porphyry that cut these rocks. The Harmony Formation has been complexly folded in this area and is cut by many faults. The workings are mainly along mineralized faults and fractures.

The principal workings (pl. 16) are on the Buckingham, Midland, Northland, Fairview, and Miss Nevada claims. These workings are described separately under the claim names.

Buckingham claim.-The workings on the Buckingham claim include an inclined shaft 850 feet deep and drifts on the $70,120,200,300,400$, and 500 levels. The shaft was inaccessible below the 120 level at the time the property was mapped in 1952 , but it was reported to be open to the 500 level early in 1955 .

The inclined shaft follows the Buckingham fault zone that strikes N. $20^{\circ}$ W. to N. $30^{\circ}$ E. and dips $30^{\circ}$ ot $50^{\circ}$ $\mathrm{W}$. and averages about $40^{\circ} \mathrm{W}$. The wallrock is hornfels and quartzite of the Harmony Formation which is intensely sheared along the fault for a width of 10 to 15 feet. Subparallel shears occur also in the adjacent rock. The Buckingham fault is probably a reverse fault or steep thrust fault. To the south, a block of the Scott Canyon Formation has been brought up in contact with the Harmony Formation along this fault.

The ore bodies mined along the Buckingham fault were mainly lead-silver deposits in which galena, sphalerite, pyrite, and a little tetrahedrite were the major sulfide minerals. Hill $(1915$, p. 81$)$ reported that the ore at the bottom of the incline, which was then at the 120 level, averaged $\$ 14.75$ a ton in gold and silver. In 1955 Mr. Ramsay of the C \& R Nevada Mines Co. reported that ore on the 400 and 500 levels was as much as 5 to 7 feet wide and that assays showed $\$ 50$ or more a ton, mainly in silver.

Midland and Hardy (58).-The workings on the Midland claim include the Midland adit, the Hardy adit and shaft, and shallow pits.

The Midland adit is 300 feet long. It exposed a fault zone that strikes northeastward in hornfels and quartzite of the Harmony Formation (pl. 16). Near the face a drift follows a shear zone that strikes $\mathrm{N}$. $70^{\circ}$ to $75^{\circ} \mathrm{W}$. and dips $25^{\circ}$ to $30^{\circ} \mathrm{NE}$; this drift was caved and inaccessible in 1955.

The Hardy workings, 110 feet east of the Midland adit, explore a vein along a fault zone that strikes north and dips steeply west; these workings include a shaft 100 feet deep and connecting level workings. Narrow ore shoots of pyrite, galena, sphalerite, chalcopyrite, tetrahedrite, and arsenopyrite have been stoped along the vein (fig. 4). A little chalcocite is present locally. According to Hill $(1915$, p. 80$)$, the ore averaged $\$ 18$ in silver, $\$ 1.50$ in gold, $\$ 10$ in lead, and $\$ 16$ in zinc to the ton. The shipments from the Hardy workings are grouped with shipments from the other parts of the property.

Northland claim.-The workings on the Northland claim were caved and inaccessible at the time of visit in 1952. Hill $(1915$, p. 80$)$ reports that a vein striking N. $10^{\circ}$ E. and dipping $30^{\circ} \mathrm{NW}$. was explored in a $200-$ foot drift and a 150-foot incline. The ore is oxidized to a depth of 25 feet below the surface. Below this the vein contains disseminated pyrite and arsenopyrite accompanied by stringers of white quartz. No lead or zinc sulfides were seen. 
Fairview claim.-The Fairview claim is northwest of the Northland (fig. 86). The workings were caved at the time of visit in 1952. According to Hill (1915, p. 81 ), a vein that strikes $\mathrm{N} .11^{\circ} \mathrm{E}$. and dips $50^{\circ} \mathrm{NW}$. was explored in an inclined shaft. Cupriferous pyrite was found 75 feet down the shaft. The pyrite is in stringers 4 to 8 inches wide near the hanging wall of the vein which was said to run $\$ 12$ a ton in gold, silver, and lead. In the oxidized zone, the fracture filling includes iron oxide and possibly sulfates of lead and iron.

Miss Nevada claim (54).-The workings on the Miss Nevada claim are in the canyon half a mile northwest of the Buckingham camp. According to Hill (1915, p. 79), the workings comprise a crosscut that runs S. $50^{\circ}$ E. for 130 feet on the south side of the canyon and a 25 -foot winze near the face on a vein that strikes $\mathrm{N}$. $30^{\circ} \mathrm{E}$. and $\operatorname{dips} 40^{\circ} \mathrm{NW}$. The vein was reopened in late 1954 by the C \& R Nevada Mines Co. It is reported that three stringers in the face over a width of 2 feet assayed 0.04 ounce of gold and 22.6 ounces of silver to the ton, and 13.5 percent lead and 28.5 percent zinc.

Hill (1915, p. 80) also mentions shallow prospects in the area between the Miss Nevada and Midland veins. Some of these prospects have shows of gold ores and others have shows of silver-lead ores.

Gold Top mine (60)

The Gold Top mine (erroneously shown on the Antler Peak topographic map as the Red Top mine) is in the SW1/4 sec. 30, T. 32 N., R. 44 E., at an altitude of 5,850 feet along Licking Creek. The principal opening is an adit about 300 feet long that was driven northward to intersect a steeply dipping fault zone (pl. 16). Mrs. Gertrude Burridge of Battle Mountain owned the property in 1955. The production records are not available; fragmentary records indicate that ore containing up to 6 ounces of gold to the ton has been selectively mined. One record of shipment contained 3.32 ounces of gold and 3.0 ounces of silver to the ton. The workings are in hornfels and quartzite of the Harmony Formation and quartz monzonite which have been cut by northeasttrending shears. The ore deposits are narrow quartz veins containing pockets of sulfide minerals, mainly pyrite.

\section{Copper Queen mine (61 and 62)}

The Copper Queen mine is in the western part of Copper Basin on the west slope of Vail Gulch. The property consists of about 20 claims in the NE1/4 sec. 30, T. 32 N., R. 44 E., which are owned by the Lemaire family of Battle Mountain.

The Copper Queen was probably one of the early discoveries in the Copper Basin area. Production began in the 1880's and continued intermittently until 1930
The property was owned by W. G. Lee and C. W. Burge in 1921 and was sold to Henry Lemaire and James Watt in that year. Production during the next few years was mainly by lessees from workings on the Copper Queen No. 1 claim. About 1918 an ore body was discovered on the Copper Queen No. 4 claim which proved to be the largest thus far found. Between 1927 and 1930, it is reported that this ore body yielded more than 11,000 tons of ore ranging from 5 to 10 percent copper. The recorded production of the Copper Queen mine is as follows:

Production of gold, silver, copper, and lead, Copper Queen mine, $191^{\prime \prime}-51$

[Furnished by U.S. Bur. of Mines; published with permission of the owner]

\begin{tabular}{|c|c|c|c|c|c|}
\hline Year & $\begin{array}{c}\text { Ore } \\
\text { (tons) }\end{array}$ & $\begin{array}{c}\text { Gold } \\
\text { (ounces) }\end{array}$ & $\begin{array}{l}\text { Silver } \\
\text { (ounces) }\end{array}$ & $\begin{array}{l}\text { Copper } \\
\text { (pounds) }\end{array}$ & $\underset{\text { (pounds) }}{\text { Lead }}$ \\
\hline 19219 & \begin{tabular}{r}
2,554 \\
353 \\
20 \\
25 \\
495 \\
909 \\
568 \\
2,671 \\
186 \\
254 \\
-115 \\
92 \\
570 \\
1,123 \\
87 \\
1,741 \\
\hdashline-26 \\
41
\end{tabular} & $\begin{array}{r}0.20 \\
23.51 \\
12.0 \\
5.30 \\
7.16 \\
20.0 \\
1.0 \\
3.0 \\
4.0 \\
4.0 \\
6.0 \\
14.0 \\
\\
\end{array}$ & $\begin{array}{r}921 \\
27 \\
106 \\
5 \\
341 \\
324 \\
381 \\
347 \\
34 \\
53 \\
--1- \\
14 \\
108 \\
148 \\
13 \\
668 \\
--14 \\
14\end{array}$ & $\begin{array}{r}332,752 \\
42,952 \\
4,278 \\
-152,605 \\
224,764 \\
96,550 \\
315,706 \\
25,517 \\
42,370 \\
-25,005 \\
9,407 \\
51,735 \\
55,093 \\
10,269 \\
125,869 \\
-3,713 \\
4,650\end{array}$ & 6,000 \\
\hline
\end{tabular}

1 No production.

As the workings on the Copper Queen Nos. 1 and 4 claims are entirely separate and are on different faults, they are described separately.

Copper Queen No. 4 workings (61).-The No. 4 workings include an inclined shaft 230 feet long and the 120 and 200 levels. A stope intermediate between the two levels is connected to them by winzes and raises. An adit 230 feet long connects with the 120 level. In all, the workings aggregate about 1,700 feet (pl.16).

The workings are in hornfels and quartzite of the Harmony Formation and in quartz monzonite porphyry dikes that cut these rocks. The principal stopes are along a fault zone that strikes N. $65^{\circ} \mathrm{E}$. and dips $40^{\circ}$ to $45^{\circ} \mathrm{NW}$.

'The ore minerals are mainly chalcocite and cuprite with native copper in places (fig. $3 A$ ). Locally these minerals are altered to copper carbonates, principally malachite, and to chrysocolla. These minerals were probably localized by the fault which controlled downward percolation of copper-bearing solutions. The source of the copper is probably, in part, from the upper part of the fault zone. The upper part of the stope north of the inclined shaft reportedly contained gold- 
copper oxidized ore which was probably derived originally from primary sulfides.

The ore bodies have been stoped intermittently for 300 feet along the strike and 230 feet (160 feet vertically) down dip. Because the ground swells after being opened, the stopes cave readily and are for the most part inaccessible. The 120 level above the intermediate stope was only partly accessible the last time the mine was visited in 1953.

Copper Queen No. 1 (Dipper) workings (62).-The Copper Queen No. 1 workings are about 1,000 feet southwest of the No. 4 workings. They consist of 215 feet of drifts and crosscuts and an inclined shaft 190 feet deep which is caved near the bottom. The shaft runs northeastward at an inclination of $30^{\circ}$. The drifting and crosscutting is northwest and southeast of the shaft, 75 feet below the collar.

The mine workings explore a low-angle fault that strikes N. $60^{\circ}$ to $75^{\circ} \mathrm{W}$. and dips $35^{\circ}$ to $45^{\circ} \mathrm{NE}$. The fault cuts metamorphosed sandstone and shale of the Harmony Formation and contains secondary copper minerals. A few small pods of ore were mined on the 75 level (pl. 16). The workings also explore small fractures and faults in the footwall of the main fault, but no ore bodies were found. Chalcocite, malachite, and minor amounts of azurite and chrysocolla are the ore minerals.

\section{Hawkeye mine (64)}

The Hawkeye mine (pl. 16) is near the center of sec. 29, T. 32 N., R. 44 E., on the hill east of the Copper Queen mine. The mine is in argillized quartzite and hornfels of the Harmony Formation which has been cut by north- and east-trending faults. The workings consist of a crosscut adit about 410 feet long and east-west trending drifts at 310 feet and 390 feet from the portal. There is no recorded production. Except for iron and copper sulfate coatings on fractures, and veins of quartz and pyrite as much as 6 inches wide, no metallization was noted in the workings.

\section{Little Giant mine (56)}

The Little Giant mine is in the NE $1 / 4$ sec. $36, T$. 32 N., R. 43 E., and NW11/4 sec. 31, T. 32 N., R. 44 E., on the ridge north of the O'Leary (Buckingham) mine. The Little Giant was discovered in June 1867 by G. W. Fox and was the first steady producer in the district (Hague, 1870, p. 317-319). The property was worked in the 1880's by T. E. H. Lee and was acquired by Jess Orwin about 1905. The ore was treated in a mill about half a mile north of the workings which was orginally equipped with 5 stamps and later with 10 stamps and Deister sand and slime tables as well. The property consists of five claims of the Silver Leaf group and has been owned by Mrs. Gertrude Burridge of Battle Mountain since 1938.

The early production records of the Little Giant mine are fragmentary. Hague states (1870, p. 317-319) that the production amounted to nearly $\$ 70,000$ by July 1 , 1869. Raymond (1872, p. 216) gives the production for 1870 as 273.7 tons valued at $\$ 32,629.90$, an average value of more than $\$ 119$ a ton. Production in 1871 amounted to 10 tons valued at $\$ 1,490$. No records of the production during the 1880's and 1890's are available; W. G. Lee, son of T. E. H. Lee, the owner at that time, states that the total production to 1905 was about $\$ 500,000$. Available records of production from 1903 to 1936 are as follows: Production of gold, silver, copper, and lead, Little Giant mine,

[Furnished by U.S. Bur. of Mines; published with permission of the owner]

\begin{tabular}{|c|c|c|c|c|c|}
\hline Year & $\begin{array}{c}\text { Ore } \\
\text { (tons) }\end{array}$ & $\begin{array}{c}\text { Gold } \\
\text { (ounces) }\end{array}$ & $\begin{array}{c}\text { Silver } \\
\text { (ounces) }\end{array}$ & $\begin{array}{c}\text { Copper } \\
\text { (pounds) }\end{array}$ & $\begin{array}{c}\text { Lead } \\
\text { (pounds) }\end{array}$ \\
\hline 1903 & $\begin{array}{l}25 \\
40\end{array}$ & $\begin{array}{c}9.67 \\
10.0\end{array}$ & $\begin{array}{l}1,591 \\
3,000\end{array}$ & & $\begin{array}{l}1,120 \\
2,400\end{array}$ \\
\hline - & 44 & 12.58 & 3,375 & & \\
\hline $1906 \ldots$ & 120 & 45.0 & 12,800 & & 16,800 \\
\hline 1907 & $\begin{array}{l}347 \\
265\end{array}$ & 43. 92 & $\begin{array}{l}6,271 \\
5,398\end{array}$ & & $\begin{array}{l}22,210 \\
40,405\end{array}$ \\
\hline 1912 & 50 & 1. 94 & 752 & 13 & 3,840 \\
\hline 1922 & 54 & 27.93 & 2,715 & 102 & 3,086 \\
\hline 1936 & & 7.0 & 786 & -- & 5,753 \\
\hline
\end{tabular}

The ore milled since 1903 was variable in grade and contained from 14 to 167 ounces of silver to the ton, as much as 0.5 ounce of gold, and up to 7 percent of lead.

The workings (pl. 16) consist of 7 adits, 2 opencuts, and several shallow pits. These workings explore veins in a sheared zone that strikes N. $20^{\circ}$ to $65^{\circ} \mathrm{W}$. and averages about $\mathrm{N} .40^{\circ} \mathrm{W}$. The zone dips southwest $15^{\circ}$ to $70^{\circ}$ and averages about $50^{\circ}$. The showings extend more than 2,100 feet along the strike, but the productive workings are mainly in the southern part and fall within a 1,200-foot stretch that has a vertical extent of 200 feet (pl. 16). The workings are mainly in the Harmony Formation which in this area is metamorphosed to quartzite and hornfels. Dikes of quartz monzonite porphyry and diabase were cut in the No. 5 adit.

The primary ore in the Little Giant vein contains pyrite, arsenopyrite, galena, sphalerite, and a little tetrahedrite. The ore in the upper workings is oxidized and consists mostly of iron oxides, jarosite, cerussite, and anglesite. Hill (1915, p. 82$)$ reported the presence of argentite and polybasite associated with remnants of unoxidized galena in the oxidized ores. He also mentions the presence of secondary tetrahedrite, polybasite, pyrargyrite, and argentite on the No. 5 level. It seems more likely that the tetrahedrite is primary, but the others may be either primary or secondary. 
Hill noted that the highest grade silver ore came from the flatter parts of the veins where the dip is $15^{\circ}$ to $20^{\circ}$ $\mathrm{SW}$. The vein was 8 to 10 inches wide at these places and contained as much as 150 ounces of silver to the ton.

The ore bodies that have been mined were mainly in the upper workings. A stope along the No. 4 adit was 80 feet long and was mined up dip for 60 feet. A stope from the No. 3 adit was 83 feet long and was mined up dip for as much as 40 feet. The stoping was nearly continuous from the No. 3 adit to the surface at the summit of the ridge, a down dip extent of almost 120 feet. Most of the stopes were narrow, ranging from 1 to 3 feet wide, but in places where the dip flattened the thickness was locally more than 5 feet.

Irish Rose mine (55)

The Irish Rose mine is in the NW1/4 sec. $36, \mathrm{~T} .32 \mathrm{~N}$., R. $43 \mathrm{E}$., on the southwest side of the Copper Basin area. The property, which consists of 12 claims, was operated intermittently for many years during the early days of the camp, but the production of this period is not known. From 1922 to 1924, it was worked primarily for arsenic by the Toulon Arsenic Co. Since 1924 the property has been idle. The owner in 1955 was Mrs. Gertrude Burridge of Battle Mountain. The available production figures are as follows:

Production of gold, silver, copper, and lead, Irish Rose mine, 1922-24

[Furnished by U.S. Bur. of Mines; published with permission of the owner]

\begin{tabular}{|c|c|c|c|c|c|}
\hline Year & $\begin{array}{c}\text { Ore } \\
\text { (tons) }\end{array}$ & $\begin{array}{c}\text { Gold } \\
\text { (ounces) }\end{array}$ & $\begin{array}{c}\text { Silver } \\
\text { (ounces) }\end{array}$ & $\begin{array}{c}\text { Copper } \\
\text { (pounds) }\end{array}$ & $\begin{array}{c}\text { Lead } \\
\text { (pounds) }\end{array}$ \\
\hline $\begin{array}{l}1922 \\
1923 \\
1924\end{array}$ & $\begin{array}{l}1,148 \\
5,215 \\
4,552\end{array}$ & $\begin{array}{c}54.4 \\
320.75 \\
232.72\end{array}$ & $\begin{array}{r}4,435 \\
51,973 \\
33,631\end{array}$ & $\begin{array}{r}6,243 \\
17,416 \\
22,820\end{array}$ & $\begin{array}{r}47,871 \\
417,864 \\
287,393\end{array}$ \\
\hline
\end{tabular}

The workings (pl. 16) are along a fault that strikes N. $20^{\circ}$ W. to N. $10^{\circ} \mathrm{E}$. and dips $45^{\circ}$ to $70^{\circ} \mathrm{W}$. in quartzite and hornfels of the Harmony Formation. The fault zone generally consists of two strands, a hangingwall strand and a footwall strand separated by a quartzsulfide vein filling or sulfide-bearing crushed rock.

The workings consist of an adit 820 feet long and an inclined shaft that is now filled with water. The adit is at an altitude of about 6,475 feet. Starting 100 feet in from the portal, the vein has been stoped for 560 feet; locally some stopes are continuous to the surface.

The ore minerals in the Irish Rose vein are arsenopyrite, pyrite, sphalerite, galena, and chalcopyrite which are accompanied by quartz and locally calcite (fig. $5 \mathrm{~A}$ ). A little stibnite, partially altered to antimony oxides, is reported to have come from an open pit about 200 feet south of the portal of the Irish Rose adit.

The ore was variable in grade; during 1923 shipments averaged 0.0615 ounce of gold, 9.96 ounces of silver, 0.17 percent copper, and 4 percent lead. The zinc content was not recorded. The ranges of constituents usually fell within the following limits: 0.03 to 0.38 ounce of gold and 1.6 to 31.6 ounces of silver to the ton, 1.1 to 4.3 percent lead, 11.8 to 33.6 percent arsenic, 16.2 to 20.4 percent sulfur, about 22 percent iron, 8.0 to 32.2 percent insoluble. In general, when the gold assay was high, silver was low; high gold assays usually accompanied high arsenic assays.

The stopes were for the most part inaccessible in September 1953, but in accessible stopes the ore mined was from 2 to 10 feet thick. The stopes extended 60 feet or more above the level, and it is probable that the stoping was nearly continuous. It is reported that ore extends down the winze, but no ore has been stoped below the level.

LEAD-SILVER DEPOSITS NORTHEAST OF COPPER BASIN

Several narrow lead-silver veins have been explored in shallow workings northeast of Copper Basin. Most of the veins cut the Antler Peak Limestone. The ore shoots discovered thus far have been small, but commonly high in grade. Ore from the Lemaire mine just outside the quadrangle is typical of the ore found in the lead-silver deposits (fig. $3 B$ ).

\section{Bailey Day mine (83)}

The Bailey Day mine is near the range front north of Copper Basin in the $\mathrm{SW} 1 / 4$ sec. 21 , T. 32 N., R. 44 E. It was probably included with the group of 6 claims known as the Bailey Day and Angela group owned by Mrs. Petra Mendive of Battle Mountain. In 1954 the property was under lease to W. O. Broyles. Although the production records show ore shipments were made only from 1934 to 1948 , it seems quite likely that a small tonnage of copper ore was shipped during the early activity of the district but was not recorded. According to the production records, the mine has yielded 2,247 tons of ore which averaged 0.58 ounce of gold, 1.2 ounces of silver, and 1.2 percent copper to the ton.

\section{Production of gold, silver, copper, and lead, Bailey Day mine, $1934-48$}

[Furnished by U.S. Bur. of Mines; published with permission of the owner]

\begin{tabular}{|c|c|c|c|c|c|}
\hline Year & $\begin{array}{l}\text { Ore } \\
\text { (tons) }\end{array}$ & $\begin{array}{c}\text { Gold } \\
\text { (ounces) }\end{array}$ & $\begin{array}{c}\text { Silver } \\
\text { (ounces) }\end{array}$ & $\begin{array}{c}\text { Copper } \\
\text { (pounds) }\end{array}$ & $\underset{\text { (pounds) }}{\text { Lead }}$ \\
\hline $\begin{array}{l}1934 \\
1935 \\
1936 \\
1937 \\
1938 \\
1940\end{array}$ & $\begin{array}{r}859 \\
384 \\
78 \\
102 \\
51 \\
45 \\
96\end{array}$ & $\begin{array}{c}762.59 \\
191.9 \\
40.0 \\
38.0 \\
7.0 \\
9.0 \\
9.0\end{array}$ & $\begin{array}{r}605 \\
482 \\
37 \\
199 \\
148 \\
43 \\
1.8\end{array}$ & $\begin{array}{r}17,909 \\
4,826 \\
783 \\
2,590 \\
1,817 \\
710 \\
3,491\end{array}$ & 212 \\
\hline 1942 & $\begin{array}{r}23 \\
463 \\
226\end{array}$ & $\begin{array}{r}10.0 \\
157.0 \\
77.0\end{array}$ & $\begin{array}{r}11 \\
749 \\
366\end{array}$ & $\begin{array}{r}235 \\
15,095 \\
7,518\end{array}$ & \\
\hline
\end{tabular}


The mine workings (pl. 17) consist of two short adits which aggregate 320 feet and a 150-foot inclined shaft with a level 36 feet below the collar. An 80-foot vertical shaft a few hundred feet northwest of the inclined shaft was inaccessible.

In the vicinity of the mine workings, the rocks are sandstone and shale of the Harmony Formation and conglomerate of the Battle Formation. The two adit levels explore faults and shear zones in the Harmony Formation which contain secondary copper minerals. Although some stoping was done along the faults, most of the ore mined in the adits came from a sandstone bed which was bounded by bedding-plane faults. The bed, which ranged from 2 to 4 feet in thickness, was impregnated with secondary copper minerals; the copper minerals extend outwards away from the bed along fractures and faults. The ore consisted of malachite, chrysocolla, azurite, and tenorite accompanied by some limonite.

The inclined shaft explores the contact between the Harmony Formation and the overlying conglomerate of the Battle Formation. In most places in the district this contract is an unconformity, but in the vicinity of the mine it is a low angle fault of small displacement (pl. 17). Apparently the low angle fault was one of the major controls that localized the ore body which was mined from the inclined shaft. The ore body was stoped 70 feet along strike, 65 feet downdip, and averaged about 4 feet in width. The ore consists of limonite and hematite containing gold and a little silver and copper. No sulfide minerals were noted in the workings, but the primary ore probably consisted mainly of auriferous pyrite and a little chalcopyrite.

\section{ELDER CREEK AREA}

The Elder Creek area is on the northeast side of the range about 7 miles west of the town of Battle Mountain. In this area the Harmony Formation has been cut by intrusive stocks and dikes of granodiorite. Most of the mines are in the contact-metamorphic aureoles that surround the intrusive bodies, but a few small veins in the intrusive rock have also been explored. In places near the granodiorite contact, the Harmony Formation is highly silicified and has been cut by quartz veins, many of which contain scheelite, but as yet no commercial scheelite deposits have been discovered.

All the production from the area has come from pyritic copper veins containing gold and silver. As the veins are too low grade to work in the sulfide zone, most of the exploration and all the stoping has been done in the oxidized zone.

MORNING STAR MINE (89)

The Morning Star mine is on a small hill near the mouth of Elder Creek in the SE1/4 sec. 36, T. 33 N., R. $43 \mathrm{E}$. The property was discovered by W. O. Broyles of Battle Mountain and has been operated by him or his sons since its discovery. The first recorded production from the property was in 1905 when 20 tons of ore was shipped, which averaged 1.9 ounces gold, 10.0 ounces silver, and 7.5 percent copper to the ton. The total recorded production from the mine is 229 tons of ore averaging 0.85 ounce gold, 2.2 ounces silver, and 4.0 percent copper to the ton. The production record of the property follows:

Production of gold, silver, and copper, Morning Star mine, 1905-38

[Furnished by U.S. Bur. of Mines; published with permission of the owner]

\begin{tabular}{|c|c|c|c|c|}
\hline Year & $\begin{array}{c}\text { Ore } \\
\text { (tons) }\end{array}$ & $\begin{array}{c}\text { Gold } \\
\text { (ounces) }\end{array}$ & $\begin{array}{c}\text { Silver } \\
\text { (ounces) }\end{array}$ & $\begin{array}{l}\text { Copper } \\
\text { (pounds) }\end{array}$ \\
\hline 1905 & $\begin{array}{l}20 \\
69 \\
14 \\
53 \\
21 \\
52\end{array}$ & $\begin{array}{l}38.70 \\
49.95 \\
15.46 \\
25.0 \\
10.0 \\
55.0\end{array}$ & $\begin{array}{r}200 \\
139 \\
12 \\
57 \\
28 \\
53\end{array}$ & $\begin{array}{l}3,000 \\
5,736 \\
1,920 \\
3,847 \\
1,470 \\
2,351\end{array}$ \\
\hline
\end{tabular}

Surface workings consist of a few shallow inclines and a glory hole 60 feet long, 20 feet wide, and averaging 25 feet deep. The underground workings consist of 660 feet of drifts and crosscuts, a winze 105 feet deep, and a 40-foot raise (pl. 17). The main adit level, which runs 400 feet eastward, ends nearly under the glory hole and is 106 feet below the glory hole.

In the vicinity of the mine, the Harmony Formation has been metamorphosed to dark biotite hornfels and quartzite. Silicification and argillic alteration are common adjacent to many of the faults. The faults cut by the mine workings generally strike northwest and dip steeply to the southwest. A small ore body, consisting mostly of chalcocite, was mined 70 feet below the collar of the vertical winze.

Chrysocolla, malachite, chalcocite, pyrite, and a little azurite and tenorite comprise the main ore minerals. As can be seen from the production records, the ore contained significant amounts of gold and a little silver. The main gangue minerals are quartz, limonite, and gypsum.

\section{BIG PAY MINE (87)}

The Big Pay mine is near the head of a small draw at the range front east of Elder Creek in the SE1/4 sec. 1, T. 32 N., R. 43 E. The mine workings, which consist of a vertical shaft and 155 feet of level workings 45 feet below the collar of the shaft, follow mineralized faults of small displacement in slightly metamorphosed shale and sandstone of the Harmony Formation. The faults explored on the 45 level have a maximum displacement of 10 feet and contain small amounts of malachite, chalcocite, and pyrite (pl.17). 
The lower workings of the mine were inaccessible at the time of visit, as water stands in the shaft 80 feet below the collar.

Recorded production from the property is tabulated below. It is unlikely that the shipment of lead ore made in 1930 came from the Big Pay mine.

Production of gold, silver, copper, and lead, Big Pay mine, 1929-37

[Furnished by U.S. Bur. of Mines; published with permission of the owner]

\begin{tabular}{r|r|r|r|r|r}
\hline Year & $\begin{array}{c}\text { Ore } \\
\text { (tons) }\end{array}$ & $\begin{array}{c}\text { Gold } \\
\text { (ounces) }\end{array}$ & $\begin{array}{c}\text { Silver } \\
\text { (ounces) }\end{array}$ & $\begin{array}{c}\text { Copper } \\
\text { (pounds) }\end{array}$ & $\begin{array}{c}\text { Lead } \\
\text { (pounds) }\end{array}$ \\
\hline 1929 & & 1.08 & 80 & 2,206 & \\
\hdashline & 27 & 2.77 & 475 & 1,194 & 6,000 \\
1930 & 13 & 1.0 & 69 & 1,754 & \\
\hline
\end{tabular}

GRACIE (ELDER CREEK) MINE (88)

The Gracie mine is in a narrow canyon on the west side of Elder Creek in the NE1/4 sec. 11, T. 32 N., R. $43 \mathrm{E}$. The underground workings total 555 feet of crosscuts and drifts on two adit levels and an 80-foot raise from the upper adit to the surface. Some ore was mined from a small glory hole 25 feet long, 30 feet deep, and 3 feet wide on top of the ridge 130 feet above the upper adit level. The present owner is James Bennett of Battle Mountain.

Early shipments from the property were made under the name of the Elder Creek mine, but in 1928 a shipment of ore was made under the name of the Gracie mine. The production for the four recorded years totalled 1,949 tons of ore that averaged 0.03 ounce gold, 1.97 ounces silver, and 3.0 percent copper to the ton. Recorded production from the property is tabulated as follows:

Production of gold, silver, and copper, Gracie (Elder Creek) mine, 1917-28

[Furnished by U.S. Bur. of Mines; published with permission of the owner]

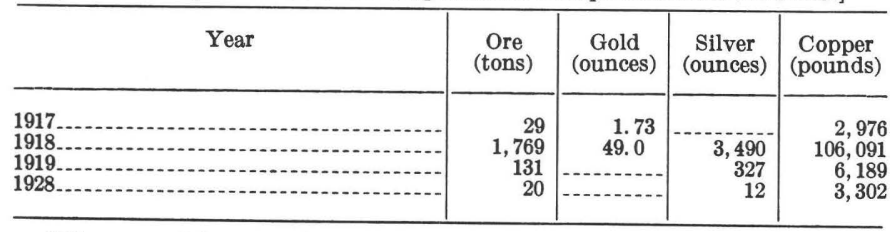

The workings of the Gracie mine are in highly metamorphosed shale and sandstone of the Harmony Formation cut by faults which strike northwest and dip southwest. Most of the workings are aiong a mineralized fault that strikes N. $16^{\circ} \mathrm{W}$. and dips $40^{\circ}$ to $75^{\circ}$ SW. (pl. 17). The fault has been explored for 500 feet along the strike and 250 feet down dip. Small ore bodies, now mostly inaccessible, were found along the fault to a depth of 130 feet below the surface.

Chalcocite is the main ore mineral, though malachite and some cuprite, azurite, and chrysocolla are also found in the ore. Quartz, jarosite, and limonite constitute the main gangue minerals. Pyrite, which occurs as crystals and small veinlets in quartz, was the only primary sulfide noted.

\section{RIDGE MINE (86)}

The Ridge mine is in the NE $1 / 4$ sec. 12, T. 32 N., R. $43 \mathrm{E}$., on the east side of Elder Creek about 1 mile from its mouth. The workings consist of two inclined shafts 400 feet apart; the south shaft is 46 feet deep and the north shaft 35 feet deep. Level workings (pl. 17) total 625 feet and consist of a crosscut adit 455 feet long that runs northeastward from the bottom of the canyon and 170 feet of drift which explores the fault on the adit level. 'The winze near the north end of the adit was inaccessible at the time of the examination, but is reported to be 108 feet deep. An 80-foot drift runs southward from the winze 50 feet below the adit level. The Ridge mine production record follows:

$$
\text { Production of gold, silver, copper, and lead, Ridge mine; }
$$

[Furnished by U.S. Bureau of Mines; published with permission of the owner]

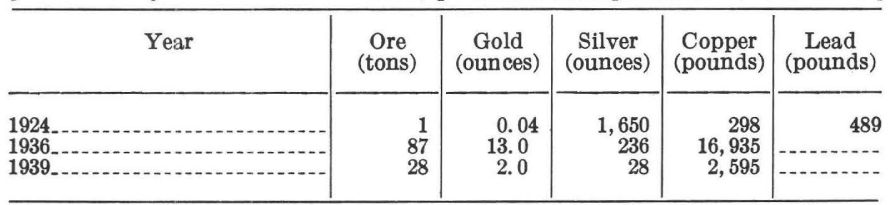

SCATTERED MINES

Many mines lie outside of the principal productive areas. Some of these, such as the Lucky Strike, Black Rock, and Buffalo Valley have significant production and will be described briefly.

DEWITT (BLUE BIRD) MINE (53)

The Dewitt mine is near the head of the north fork of Trout Creek at an altitude of 7,600 feet in the SW1/4 sec. 23, T. 32 N., R. 43 E. The property consists of six claims and is owned by Edward and Clarence Lauritzen of Battle Mountain. The early history of the property is not well known. Apparently it was originally located by Peter Nash and Donald McDonald in 1902 and about 1918 was sold to George Dewitt. No production figures are available for periods prior to 1934 when the property was acquired by E. Lauritzen and C. Lauritzen. They treated the ore in a two-stamp cyanide mill with a daily capacity of about 5 tons. The recorded production of the property follows :

Production of gold, silver, and lead, Dewitt (Blue Bird) mine, 1934-50

\begin{tabular}{|c|c|c|c|c|}
\hline Year & $\begin{array}{c}\text { Ore } \\
\text { (tons) }\end{array}$ & $\begin{array}{c}\text { Gold } \\
\text { (ounces) }\end{array}$ & $\begin{array}{c}\text { Silver } \\
\text { (ounces) }\end{array}$ & $\begin{array}{l}\text { Copper } \\
\text { (pounds) }\end{array}$ \\
\hline $\begin{array}{l}1934 \\
1935 \\
1937 \\
1938 \\
1942\end{array}$ & $\begin{array}{r}13 \\
66 \\
45 \\
208 \\
106 \\
3 \\
1 \\
4\end{array}$ & $\begin{array}{r}5.99 \\
46.48 \\
17.45 \\
74.0 \\
32.0 \\
2.0 \\
18.0\end{array}$ & $\begin{array}{c}48 \\
61 \\
26 \\
688 \\
326 \\
14 \\
70 \\
4.5\end{array}$ & 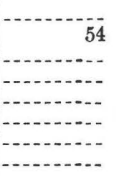 \\
\hline
\end{tabular}

[Furnished by U.S. Bur. of Mines; published with permission of the owner] 
The workings include three short adits aggregating about 400 feet in length and several shallow pits (pl. 18). The workings are mostly along a fault zone in sandstone and shale of the Harmony Formation that strikes northwest and dips $35^{\circ}$ to $62^{\circ} \mathrm{NE}$. The beds in the mine area strike north and generally dip steeply westward, but locally have east dips.

The primary sulfide minerals are pyrite and arsenopyrite and small amounts of galena and sphalerite. The ore that has been stoped is mostly oxidized ore along the fault zone and is composed largely of iron oxides. The values in the ore are mainly in gold and silver. Native silver was reported in the oxidized ore.

Most of the ore mined came from the upper adit level where the fault splits and forms two strands. Both of the strands have contained small, lenticular ore bodies.

LUCKY STRIKE MINE (51)

The Lucky Strike mine is near the head of the south fork of Trout Creek at an altitude of 7,200 feet near the center of sec. 27, T. 32 N., R. 43 E. The property, which consists of five patented claims, was discovered by C. W. Burge in 1907 and in 1955 was owned by the Kearns Estate, Salt Lake City, Utah. In 1951 the property was under lease and option to the United Minerals Co. The earliest recorded production was in 1908 when high-grade silver ore was mined from the upper workings; production has been intermittent since then until the United Minerals Co. took over the ground early in 1951. Shipments were begun soon afterward and 2,252 tons were shipped in 1951-52. The available production records are as follows :

Production of gold, silver, copper, lead, and zinc, Lucky Strike mine, 1908-52

[Furnished by U.S. Bur. of Mines; published with permission of the lessee]

\begin{tabular}{|c|c|c|c|c|c|c|}
\hline Year & $\begin{array}{c}\text { Ore } \\
\text { (tons) }\end{array}$ & $\begin{array}{c}\text { Gold } \\
\text { (ounces) }\end{array}$ & $\begin{array}{c}\text { Silver } \\
\text { (ounces) }\end{array}$ & $\begin{array}{c}\text { Copper } \\
\text { (pounds) }\end{array}$ & $\underset{\text { (pounds) }}{\text { Lead }}$ & $\begin{array}{c}\text { Zinc } \\
\text { (pounds) }\end{array}$ \\
\hline $\begin{array}{l}1908 \\
1922 \\
1923 \\
1936 \\
1937 \\
1938 \\
1952\end{array}$ & $\begin{array}{r}71 \\
54 \\
4 \\
54 \\
35 \\
118 \\
16 \\
896 \\
1,356\end{array}$ & $\begin{array}{l}2.46 \\
1.0 \\
.04 \\
1.38 \\
1.0 \\
1.0 \\
-23.0 \\
31.0\end{array}$ & $\begin{array}{r}3,700 \\
588 \\
8 \\
294 \\
1,027 \\
1,105 \\
739 \\
5,695 \\
7,235\end{array}$ & $\begin{array}{r}48 \\
473 \\
334 \\
154 \\
104 \\
\end{array}$ & $\begin{array}{r}55,952 \\
11,257 \\
15 \\
4,560 \\
17,870 \\
18,177 \\
194 \\
94,786 \\
122,329\end{array}$ & $\begin{array}{r}18,870 \\
12,554 \\
13,001 \\
224,459 \\
310,299\end{array}$ \\
\hline
\end{tabular}

The Lucky Strike mine workings aggregate 1,240 feet of level workings connected by a 160 -foot inclined shaft and about 200 fect of raises (pl. 18).

The mine area is underlain by sandstone and shale of the Harmony Formation, which strike northeast and generally dip southeast. These rocks are cut by faults that mainly strike northwest and dip steeply southwest. The ore bodies occur along these faults. The main fault in the area is the Lucky Strike fault which strikes N. $10^{\circ}-40^{\circ} \mathrm{W}$. and dips $60^{\circ}$ to $80^{\circ} \mathrm{SW}$.; it has been explored over a strike length of 600 feet, and four ore shoots have been discovered in the fault zone. Other faults that parallel the Lucky Strike fault have been cut by the workings; some of these contain small amounts of lead and zinc minerals, but no mineable ore bodies have yet been discovered.

Galena, sphalerite, and pyrite are the principal ore minerals; calcite and a little quartz are the gangue minerals. From the surface down to about 50 feet, the ore is partially oxidized to cerussite, anglesite, and smithsonite together with iron oxides and minerals of the jarosite group. A little greenockite $(\mathrm{CdS})$ coating on cavities was noted also. The ore minerals filled lenticular openings along the fault zone. Some post-ore movement is indicated by local shearing in the sulfides.

The early shipments are said to have assayed as high as 150 ounces of silver to the ton and 50 percent lead (Hill, 1915, p. 83). Shipments of 2,252 tons in 1951-52 averaged 0.02 ounce of gold and 7.1 ounces of silver to the ton, 5.9 percent lead, and 11.5 percent zinc. The high percentage of zinc, which was a deterrent to operations prior to 1951, was no problem in 1951-52. The ore was shipped to the Bauer mill of the Combined Metals Co. near Tooele, Utah, where separate lead and zinc concentrates were made.

The ore shoots are highly lenticular and pinch and swell along the strike and down dip. Individual ore shoots range from 30 to 100 feet long, 2 to 10 feet wide, and extend down dip from 50 to 250 feet. The principal stope was explored by the Dunham shaft and by a winze that intersected the shaft about 125 feet below the collar. The stope extended vertically downward and narrowed at the winze. A drift was driven northward from the winze on the 7,044 level underneath the No. 1 ore body. Sulfide showings on the level were meager, but sulfides were found in a raise 30 feet above the level near the face. Exploratory work was recessed during 1953 when lead and zinc prices dropped and had not been resumed by early 1955 .

\section{ANTIMONY OCCURRENCE ON NORTH PEAK}

During geologic mapping, a vein of antimony oxides was discovered at an altitude of 7,450 feet on the ridge that extends westward from North Peak in the SW1/4 sec. 4, T. 32 N., R. 43 E. The vein is a much as 4 inches wide and could be traced for 20 feet along the strike; it strikes $\mathrm{N} .10^{\circ}$ to $15^{\circ} \mathrm{W}$. and dips $45^{\circ} \mathrm{NE}$.

$$
\text { LAURITZEN MINE (52) }
$$

Half a mile north of the Lucky Strike mine in the NW1 $1 / 4$ sec. 27 , T. 32 N., R. 43 E., there are shallow workings on the northward extension of the Lucky Strike fault zone (pl. 18). The property is owned by 
the Lauritzen family of Battle Mountain. It was originally located about 1910 and has no recorded production.

The workings consist of two adits, one 185 feet long and the other 80 feet long. The 185-foot adit is in sandstone and shale of the Harmony Formation which is sheared on faults that strike N. $20^{\circ}$ to $30^{\circ} \mathrm{W}$. and dip $45^{\circ}$ to $60^{\circ} \mathrm{SW}$. Pods of pyrite, galena, and sphalerite occur in the sheared zone; the pyrite is mostly oxidized to a mixture of iron oxides and jarosite which masks the alteration products of the other minerals. The 80 -foot adit is in sheared chert and shale of the Scott Canyon Formation. A little pyrite, partially altered to iron oxides, occurs in the sheared zone.

\section{ANTIMONY KING MINE (49)}

The Antimony King mine is about 8 miles southwest of Battle Mountain in the north fork of Little Cottonwood Canyon in sec. 2, T. 31 N., R. 43 E., and sec. 35, T. 32 N., R. 43 E. The property consists of three patented claims, the Antimony King and Antimony King Nos. 1 and 2 (formerly known as the Mountain King and Columbia claims), and is owned by G. E. Mitchell and Lily Pesi of Battle Mountain, Nevada. The deposit was discovered about 1870, and in 1871 production amounted to 150 tons of mixed oxide and sulfide ore (Raymond, 1872, p. 213-214). According to Whitehill (1873, p. 47), antimony ore was smelted in crucibles in Battle Mountain for a time and shipped to New York. Following this period, the property lay idle for many years. Mitchell reports a production of 44 tons averaging 24 percent antimony in 1939, 9 tons of ore containing 29 percent antimony during 1940, and 70 tons of ore containing 34 percent antimony during 1941 (D. E. White, written commun., 1942).

The workings (pl. 18) consist of an inclined shaft about 100 feet deep, with connecting workings and four short adits, on the north side of Little Cottonwood Canyon; in addition, there are two adits on the ridge south of the canyon.

The mine area is underlain by contorted black shale and chert of the Scott Canyon Formation which are intruded by quartz monzonite porphyry dikes. The chert and shale generally dip steeply westward, and on the west they are in fault contact with sandstone of the Harmony Formation (pl. 3).

Stibnite is the principal antimony mineral in the ore. Near the surface the stibnite is partially altered to an antimony oxide, probably stibiconite. Quartz and pyrite accompany the antimony minerals. A sample of the ore mined in 1871 was reported to assay 62.3 percent antimony and 6.6 percent bismuth (Raymond, 1872, p. 214).
The upper workings on the ridge on the south side of the canyon follow a fault zone that strikes $\mathrm{N}$. $20^{\circ}$ to $50^{\circ}$ E. and dips $45^{\circ}$ to $65^{\circ} \mathrm{NW}$. The fault zone, which ranges from 3 to 12 feet wide, is cut by dark-gray and white quartz veins ranging from 1 to 14 inches wide that contain stibnite and pyrite; most of the stibnite is in the dark-gray quartz.

In the lower workings, on the north side of the canyon, the stibnite occurs in pods and veins containing white quartz in sheared black chert. Some of the stibnite is in a fault zone that strikes N. $20^{\circ}$ to $30^{\circ} \mathrm{E}$., but most of the ore mined came from a subsidiary fault zone that strikes N. $50^{\circ}$ to $85^{\circ} \mathrm{E}$. and dips $40^{\circ}$ to $60^{\circ} \mathrm{N}$. The best ore occurred at the intersection of the fault and a quartz monzonite dike. Stibnite occurs within a few feet of the surface, although the formation of a little stibiconite extends to a depth of about 50 feet.

FULLER GROUP (50)

The Fuller group is on the north side of the north fork of Little Cottonwood Canyon in the $\mathrm{NE} 1 / 4$ sec. 35, T. 32 N., R. 44 E. The workings are in sandstone and shale of the Harmony Formation which are cut by a quartz monzonite porphyry dike. According to Hill (1915, p. 83), "several narrow iron-stained quartz veins are exposed in the surface workings of the group, which are said to carry gold usually associated with a small amount of silver and ranging in value from $\$ 7$ to $\$ 150$ a ton. At the one tunnel which reaches the sulfides, about 25 feet below the surface, pyrite is the only metallic mineral. In another vein a little residual galena was noted, but as a rule the ores are typical pyrite gold ores."

COPPER GLANCE GROUP (84)

The Copper Glance group is north of Copper Basin on the range front in the NW1/4 sec. 21 and NE1/4 sec. 20 , T. 32 N., R. 44 E. Although the property may have produced a small tonnage of copper ore, shipment records could not be found. At the time of his visit, Hill $(1915$, p. 78$)$ describes the chief development as a 150 foot vertical shaft and a 50-foot crosscut from the shaft at a depth of 100 feet. As most of the workings were inaccessible at the time the property was examined, the workings described by Hill could not be recognized. Some of the claims of the original Copper Glance group were relocated in June 1952 by C. A. Joseph, W. G. Lee, Lee Hand, and Alvin Layton.

The workings explore mineralized faults and fractures in sandstone, shale, and limestone of the Harmony Formation. Small stocks and dikes of quartz monzonite and granodiorite intrude the sedimentary rocks in the vicinity of the workings. For the most part, the faults 
contain only iron-oxide-stained breccia. Malachite, shrysocolla, and copper pitch are found mostly along fractures and small bedding-plane faults.

Most of the development on the property is along a fault that strikes N. $60^{\circ}$ to $70^{\circ} \mathrm{E}$. and dips $50^{\circ}$ to $60^{\circ}$ NW. The fault is explored by two short adits which aggregate 175 feet and an inclined shaft of unknown depth. Many shallow shafts and short adits explore faults on both sides of the canyon. A little scheelite occurs in the limestone near the mouth of the canyon, but no commercial deposits of scheelite have been found.

GOLDEN ERA (GOOD CHANCE) GROUP (85)

The Golden Era group comprises 22 claims on the northeast side of the Battle Mountain range. Most of the claims are in the canyon southeast of Snow Gulch in the eastern half of sec. 18, T. 32 N., R. 44 E.

When Hill (1915, p. 77) visited the property, exploration work, which was mostly along two veins, consisted of 440 feet of drift and a 100-foot inclined shaft on one vein and 150 feet of drift and a shaft of unknown depth on the other vein. Since the time of Hill's visit, considerable development work has been done, mostly along a vein that was not explored until after he examined the property (pl.18).

Shipments made prior to 1938 were under the name of the Golden Era mine; since then, shipments from the property have been made under the name of the Good Chance mine. The complete history of the property is not known. The first recorded shipment was made in 1908; since that time, 728 tons of ore has been shipped which averaged 0.50 ounce of gold and 5.55 ounces of silver to the ton. Some of the ore contained copper and lead, as shown by the production records. An attempt was made by Mr. Holcomb of Battle Mountain to cyanide the ore, but as most of the ore contained some secondary copper, the process was unsuccessful.

Production of gold, silver, copper, and lead, Golden Era group, 1908-40

[Furnished by U.S. Bur. of Mines; published with permission of the owner]

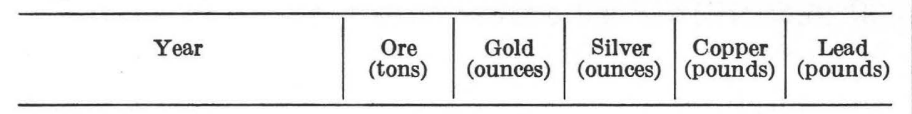

Golden Era mine

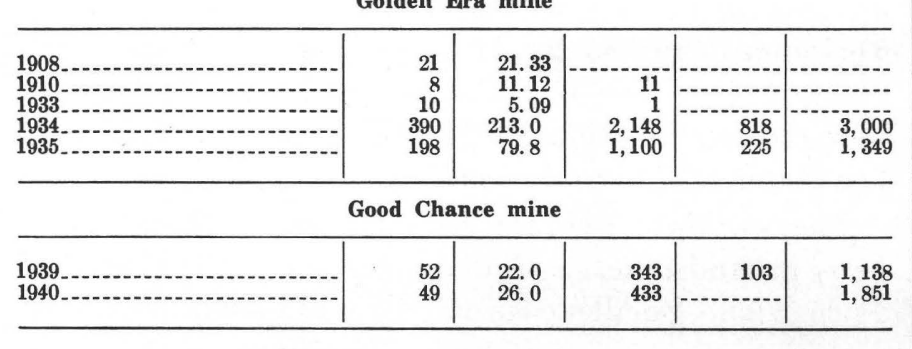

The workings, which include adits and shallow shafts, explore steeply dipping, mineralized faults containing siliceous gold ore. At the time the property was examined, most of the old workings were inaccessible. The workings of the Good Chance mine were open, however, and as it has accounted for most of the production from the group, it was mapped (pl. 18). The mine is accessible by two surface openings: a 200 -foot inclined shaft and the main adit level which is 850 feet long. Two sublevels aggregating 180 feet of drifts, 90 feet of crosscuts, and 150 feet of raises constitute the additional workings.

A mineralized fault zone which strikes N. $27^{\circ} \mathrm{E}$. and dips $45^{\circ}$ to $65^{\circ} \mathrm{NW}$. is explored by the workings. The fault zone cuts metamorphosed sandstone and shale of the Harmony Formation and contains pyrite, quartz, arsenopyrite, and minor amounts of gold, galena, chalcopyrite, and sphalerite. Oxidation of these sulfides near the surface formed small ore bodies that were mined mainly for their gold content.

The mine is near the border of the contact metamorphic aureole, and the workings explore a mineralized fault in the Harmony Formation. The fault which strikes N. $10^{\circ}$ to $25^{\circ} \mathrm{E}$. and dips $75^{\circ}$ to $85^{\circ} \mathrm{NW}$. has been intruded by a pebble dike ranging from 1 to 3 feet wide.

Pyrite, which occurs in the fault and in places extends into the wallrock, was the only primary sulfide noted. Small amounts of malachite and chalcocite, associated with quartz, limonite, and jarosite, occur along the fault. For the most part, the pebble dike is barren, but locally it contains pyrite and a little secondary copper. Mr. Hinman, the mine owner, reports that a little native copper and native silver were found southwest of the winze on the main adit level. Most of the ore shipped from the property came from the drift which extends southwest from the winze, 50 feet below the adit level. The ore, which contained copper, silver, and gold, was probably a small lens composed mainly of secondary chalcocite formed near the bottom of the oxidation zone.

$$
\text { MARIGOLD MINE (90) }
$$

The Marigold mine is 5 miles south of Valmy on the northwest side of the Battle Mountain range in the NE1/4 sec. 18, T. 33 N., R. 43 E. The property consists of four claims, the Emma, Lillian, Mayflower, and Opal, at the mouth of Trout Creek. The discovery was made by Frank Horton in 1937, and he began ore shipments that year. Production records are incomplete, but it is reported that several thousand tons of gold ore averaging about $\$ 7.00$ a ton was shipped during the next 3 years. Cyanide tanks were installed in 1940, and several unsuccessful attempts have been made to operate the property since then.

The rocks in the mine area consist of quartzite, shale, and chert of the Valmy Formation; conglomerate, sand- 
stone, and shale of the Battle Formation; and chert and shale of the Pumpernickel Formation (pl. 18). These rocks were cut by low-angle faults having variable strikes but generally dipping westward, and high-angle faults that strike northward and dip generally westward. The amount of displacement on the low-angle faults cannot be determined; displacement on the highangle faults ranges from 10 to 25 feet. In the vicinity of the mine, part of the Battle Formation and all the Antler Peak Limestone, which is present a few hundred feet south of the mine, has been overriden by black chert of the Pumpernickel Formation along a low-angle thrust fault. The thrust fault is part of the Golconda fault system.

In the vicinity of the mine, the conglomerate of the Battle Formation rests unconformably on quartzite and shale of the Valmy Formation. The conglomerate grades upward into coarse sandstone, except near the south end of the mine workings where the conglomerate pinches out and the sandstone rests on Valmy quartzite. Except for minor changes in attitude due to folding and faulting, the Battle Formation in the mine area strikes northeastward and dips $10^{\circ}$ to $30^{\circ} \mathrm{NW}$.

The ore that has been mined came from the basal conglomerate of the Battle Formation which has been partly replaced by iron oxides, presumably formed by alteration of pyrite. Locally the ore extends upward for a few feet into the overlying sandstone, but generally it is confined to the conglomerate which is as much as 15 feet thick in places.

The workings of the Marigold mine consist of 785 feet of drifts and crosscuts on the main adit level, and 330 feet of drift on the sublevel 26 feet above the main level. The main adit level runs 290 feet N. $76^{\circ} \mathrm{W}$. where it intersects the conglomerate of the Battle Formation; the additional 495 feet of work on the adit level explores the conglomerate along strike to the southwest and northeast (pl. 18). The stopes, which range from a few feet to 15 feet high, are nearly continuous for 300 feet along strike and 150 feet down the dip of the conglomerate.

Some work has been done on the small hill east of the main mine workings, but no ore was found. The work consisted of trenching with a bulldozer for the most part; in addition, two short adits and a few prospect pits explore shear zones in the Valmy Formation.

\section{RED ROCK GROUP (91)}

The Red Rock group of four claims is in Trout Creek about half a mile south of the Marigold mine. The property is owned by George Hinman of Battle Mountain. The workings are on the east side of the valley just above the valley floor; they explore a fault zone that strikes north and dips steeply west. The workings consist of a shaft 100 feet deep, an adit 40 feet long, and shallow cuts. The fault zone is iron stained and is said to give assays of gold of fair grade. No ore has been shipped.

TRENTON COPPER PROSPECT (92)

The Trenton Copper prospect is near the head of Trenton Canyon at an altitude of about 7,500 feet in sec. 24, T. 32 N., R. 42 E. The workings consist of several shallow trenches in hornfels and conglomerate of the Battle Formation in the contact aureole of the granodiorite in Trenton Canyon. In this area the sedimentary rocks strike northward and dip westward, nearly parallel to the slope. Exploratory work to date has indicated several lenticular bodies containing copper ore minerals, but the size and grade of the ore bodies have not been determined. The copper minerals include malachite, azurite, chrysocolla, and a little chalcopyrite which are accompanied by pyrite.

TRENTON MINE (93)

The Trenton mine is on the south fork of Trenton Canyon in the SW1/4 sec. 25 , T. 32 N., R. E. The property consists of a patented claim owned by René Lemaire of Battle Mountain. The property was formerly owned by Lott and Co. who shipped 10 tons of ore valued at $\$ 50$ a ton in 1870 .

The workings consist of several pits and adits, now caved, in hornfels and quartzite of the Havallah Formation near the border of the granodiorite in Trenton Canyon. The ore bodies are not accessible, but specimens collected from the dumps are composed of white quartz containing scattered pyrite, galena, chalcopyrite, and sphalerite crystals. The ore mined was said by Whitehill (1873, p. 30 ) to assay as high as $\$ 157$ a ton in silver and 12 to 14 percent copper.

BUFFALO VALLEY MINE (94)

The Buffalo Valley mine is on the west side of the Battle Mountain range about 17 miles south of Valmy in the NE1/4 sec. 33, T. 32 N., R. 42 E. According to Vanderburg (1939, p. 37-39), the property consists of 28 unpatented claims and the water rights of Mill Canyon, which is half a mile north of the mine. The property was purchased in 1916 by the Buffalo Valley Mines Co. from Clyde Ganser and others; the first ore shipments were made in 1924 .

Available records show that the property has yielded a relatively small tonnage, although the mine was worked almost continuously from 1924 to 1941 . A 10 ton cyanide plant was built in 1925, and 1,196 tons of ore was treated up to 1933.

The workings aggregate about 3,000 feet and include five adits, one of which is 600 feet long and another 
Production of gold, silver, and copper, Buffalo Valley mine, 1924-51

[Furnished by U.S. Bur. of Mines; published with permission of the owner]

\begin{tabular}{|c|c|c|c|c|}
\hline Year & $\begin{array}{c}\text { Ore } \\
\text { (tons) }\end{array}$ & $\begin{array}{c}\text { Gold } \\
\text { (ounces) }\end{array}$ & $\begin{array}{c}\text { Silver } \\
\text { (ounces) }\end{array}$ & $\begin{array}{c}\text { Copper } \\
\text { (pounds) }\end{array}$ \\
\hline 24. & & 36.0 & 111 & \\
\hline & 1473 & 239. 39 & 365 & \\
\hline 1926 & $\begin{array}{l}{ }_{2}^{2} 150 \\
2300\end{array}$ & $\begin{array}{r}106.49 \\
64.01\end{array}$ & $\begin{array}{l}39 \\
18\end{array}$ & \\
\hline $\begin{array}{l}1927 \\
1928\end{array}$ & $\begin{array}{l}2300 \\
2135\end{array}$ & $\begin{array}{l}64.01 \\
53.28\end{array}$ & $\begin{array}{l}18 \\
19\end{array}$ & \\
\hline & ${ }^{2} 308$ & 68.38 & 25 & \\
\hline 1930 & 77 & 27.32 & 44 & \\
\hline 1931 & 100 & 11.76 & & \\
\hline & 30 & 27.45 & 4 & 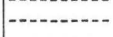 \\
\hline 1933-1934- & ${ }^{2} 200$ & $\begin{array}{l}32.78 \\
41.1\end{array}$ & & $b_{-10}$ \\
\hline -..-- & $\begin{array}{l}150 \\
250\end{array}$ & $\begin{array}{l}41.1 \\
50.59\end{array}$ & 16 & - n-c- \\
\hline - & 43 & 21.0 & 76 & 1,345 \\
\hline 1009 & 317 & $\begin{array}{r}146.0 \\
-1403\end{array}$ & 470 & 7,861 \\
\hline $\begin{array}{l}1939- \\
1940 .\end{array}$ & $\begin{array}{r}r 38 \\
42\end{array}$ & $\begin{array}{r}203.0 \\
29.0\end{array}$ & $\begin{array}{r}114 \\
56\end{array}$ & \\
\hline & 45 & & & 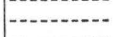 \\
\hline $1951 \ldots$ & 27 & 17.0 & 11 & -......... \\
\hline Total & 2,928 & $1,186.55$ & 1,380 & 9,607 \\
\hline
\end{tabular}

1 Of this ore 253 tons was cyanided.

2 Ore treated in cyanide plant at the Buffalo Valley mine.

400 feet long. In addition, 40 shallow pits and trenches have been dug on the surface. Three levels, connected by stopes and raises, and an inclined shaft which extends 220 feet below the surface constitute the main workings of the mine. The upper two levels are adits that were driven eastward into the hill; the lower level was worked through the inclined shaft (pl. 18).

The mine is in chert, argillite, and limestone of the Havallah Formation which strikes north and dips $35^{\circ}$ to $50^{\circ} \mathrm{W}$. in the mine area. In places near the larger faults, the dip steepens owing to the drag. The sedimentary rocks have been intruded by a granodiorite dike ranging from 50 to 80 feet wide that trends northwest and dips steeply southwest. Contact metamorphism near the dike has formed calc-silicate rock and siliceous hornfels.

The mine workings are in the footwall of the main frontal fault of the range that separates the Havallah Formation from Quaternary alluvium. The frontal fault, which bounds the workings on the west, branches in places and forms two or three major strands up to 30 feet apart that strike N. $18^{\circ} \mathrm{E}$. and $\operatorname{dip} 40^{\circ}$ to $55^{\circ}$ W. Many faults of small displacement, which strike and dip parallel to the main frontal fault, are cut by the mine workings.

The larger ore bodies were formed in calcareous beds between strands of the frontal fault; smaller ore bodies were formed in calcareous beds near shear zones and small faults in the footwall of the frontal fault zone.

The ore bodies are composed of quartz, limonite, hematite containing gold and a small amount of silver, and copper formed from the oxidation of auriferous pyrite bodies containing a little chalcopyrite. According to the shipment records, the content of gold and silver in the ore increases with an increase in copper.
The main copper minerals are malachite and chrysocolla. Although no primary ore minerals were observed in the principal workings, a shallow surface cut, 800 feet southeast of the mine, explored a vein containing pyrite and chalcopyrite reported to assay up to 2.0 ounces of gold to the ton.

\section{BLACK ROCK MINE (95)}

The Black Rock manganese mine is in the $\mathrm{SW} 1 / 4$ sec. 34, T. 32 N., R. 42 E., about 20 miles south of Valmy on the west side of Battle Mountain. The mine workings are at an altitude of 6,600 feet and are a mile east of the Buffalo Valley mine. The property consists of seven claims, the Black Rock, Nos. 1-4, and Nigger Joe, Nos. 1-3.

The Black Rock mine was discovered in January 1940 by Herbert Kattenhorn and Phil L. Reasoner. It was sold soon afterward under lease and option to the Western Alloys Co. of Salt Lake City, Utah. In December 1940 a mill of 60 tons daily capacity consisting of a crusher, screens, and two jigs was completed at the mouth of Trenton Canyon about 3 miles north of the mine. This mill was operated at intervals until 1944 and was finally closed because of difficulty in maintaining a marketable high-manganese and low-silica product. The ore stockpile and part of the tailings were later shipped to the U.S. Steel plant at Geneva, Utah, for use in the manufacture of manganiferous pig iron. In 1950 the property was leased to E. B. Potter of Battle Mountain who shipped ore to the Geneva plant until 1953. The recorded shipments follow:

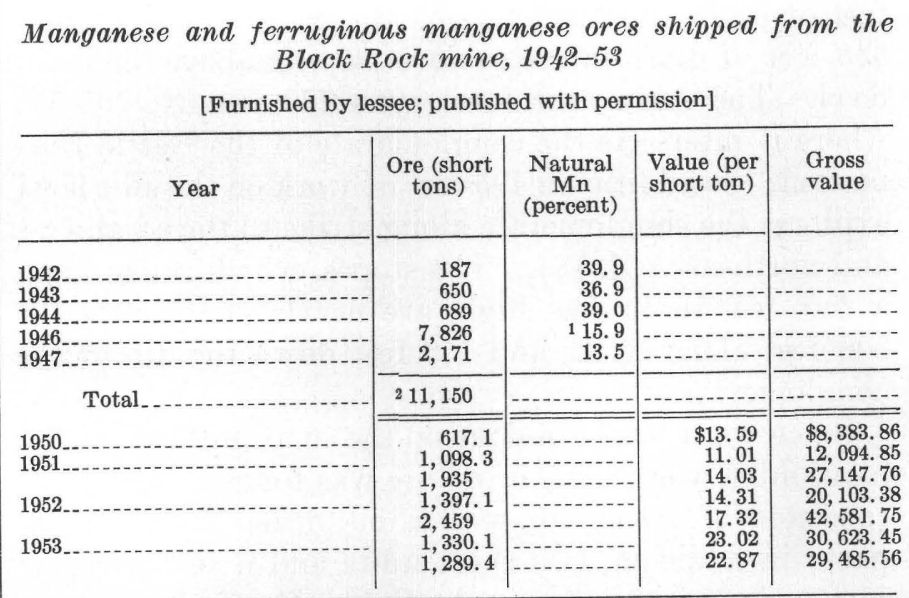

1 Dry: 5 percent moisture correction.

2 Of this figure, 1,526 tons contained more than 35 percent $\mathrm{Mn}$.

In the 1942-44 period the heads averaged about 21 percent manganese and 55 percent silica. The concentrates contained 35 to 45.8 percent manganese and 16 to 30.8 percent silica. The iron content ranged from 1.8 to 3.8 percent. One analysis showed 0.50 percent copper oxide. 
In the 1950-53 period shipments showed a range from 20 to 30 percent manganese and 49.8 to 55.4 percent silica. The ore, selectively mined as the minimum acceptable grade at the Geneva plant of the U.S. Steel Co., was 20 percent manganese. Typical assays (in percent) of the ore are as follows:

\begin{tabular}{|c|c|c|c|c|c|c|c|c|}
\hline & $\begin{array}{l}\text { Man- } \\
\text { ganese }\end{array}$ & $\begin{array}{l}\text { Insol- } \\
\text { uble } 1\end{array}$ & Sulfur & $\begin{array}{l}\text { Phos- } \\
\text { phorus }\end{array}$ & Iron & Zinc & $\underset{\text { senic }}{\text { Ar- }}$ & Water \\
\hline $\begin{array}{l}1 \\
2 \\
3\end{array}$ & $\begin{array}{l}26.3 \\
24.4 \\
20.3\end{array}$ & $\begin{array}{l}49.8 \\
50.0 \\
55.4\end{array}$ & $\begin{array}{r}0.014 \\
.013 \\
.025\end{array}$ & $\begin{array}{r}0.018 \\
.084 \\
.072\end{array}$ & $\begin{array}{l}1.3 \\
2.8 \\
3.5\end{array}$ & $\begin{array}{l}0.01 \\
.01 \\
.02\end{array}$ & $\begin{array}{l}0.01 \\
.01 \\
.01\end{array}$ & $\begin{array}{r}7.6 \\
-6.0\end{array}$ \\
\hline
\end{tabular}

${ }^{1}$ Mainly silica; one assay showed 1.34 percent $\mathrm{Al}_{2} \mathrm{O}_{3}$.

The workings ( $\mathrm{pl} .18$ ) consists of a series of opencuts in manganiferous chert, shale, and limestone of the Havallah Formation. In this area these rocks are in a minor syncline superimposed on the west flank of an anticlinal fold that forms the major structure in the west side of the range. The folds strike about N. $10^{\circ}$ to $30^{\circ} \mathrm{W}$. and plunge gently northwest.

The manganese ore bodies are in a chert unit interbedded with thin shale partings and in quartzite. On the east side of the deposit, these beds strike northward and dip steeply westward; on the west side of the deposit, the beds flatten and dip more gently to the westward.

The manganese minerals include braunite, psilomelane, pyrolusite, and wad. The braunite is believed to have formed by low-grade metamorphism from a manganiferous sedimentary deposit. Subsequently the braunite has been altered by weathering, and the secondary minerals, psilomelane, pyrolusite, and wad were formed. In part these secondary minerals were formed in place, but in part the manganese was transported downward in solution and was precipitated as oxides that replace the chert and to a lesser extent the shale and fill cavities in the host rocks.

The manganiferous chert layers are lenticular and generally range from a fraction of an inch to 6 inches; a few are as much as 2 feet thick. The chert layers are red, green, gray, and black, for the most part. The manganese oxides replace the chert, especially the thicker bedded units. Three separate bodies of manganiferous chert were mapped, which were explored by six diamond drill holes. The manganiferous material extended about 40 feet below the outcrop. Data obtained from the drilling indicates that the overall grade of the deposit was about 16 percent manganese. By jig concentration the ore was upgraded to more than 43 percent of manganese; by selective mining the highest grade attained was 30 percent manganese.

TELLURIDE MINE (96)

The Telluride mine, at the head of Rocky Canyon, in sec. 6, T. 31 N., R. 43 E., was discovered by J. Hutchins in 1910 (Cutler, 1911, p. 845). The workings consist of several shallow adits and opencuts, which were caved at the time of visit in 1953. The workings are in shale and chert of the Pumpernickel Formation.

According to Cutler (1911, p. 845), the ore deposits are quartz-iron oxide veins that contain free gold, tetradymite, and silver minerals. Assays ranging from \$2 to $\$ 500$ a ton were reported. Samples collected by the writers from the dumps were studied by Charles Milton who reports that tellurides of the josëite-tetradymite group are present.

MODOC MINE (97)

The Modoc mine is in sec. 24, T. 31 N., R. 42 E., on the ridge between Rocky Canyon and Willow Creek. The mine was discovered about 1925 by Hugh Broyle who worked the property successfully for a few years; in 1930 it was purchased by William Hertfelder who subsequently sold it to Charles Crawford of Battle Mountain (Schrader, 1933, p. 128-129).

The workings consist of a shaft 75 feet deep and a drift 100 feet long at the 40-foot level and a short drift on the 75-foot level. The drifts follow a steeply dipping. north-trending shear zone in quartz monzonite porphyry. The shear zone is as much as 3 feet wide and is partly filled with quartz-calcite veins. Some layers within the zone contained ore assaying $\$ 40$ in gold and 4 ounces of silver to the ton; the ore also contained pyrite and a little lead and copper.

Shaft No. 3, 500 feet southeast of the Modoc shaft, explores a parallel shear zone as much as $31 / 2$ feet wide that strikes N. $25^{\circ} \mathrm{W}$. Narrow stringers stained by manganese oxides in the shear zone are reported to have yielded 10 tons of ore valued at $\$ 40$ a ton.

\section{PLACER DEPOSITS}

Placer gold deposits have been worked in the Elder Creek, Licking Creek, Copper Canyon, Box Canyon, Philadelphia Canyon (Bannock), Iron Canyon, and Vail Canyon areas in Battle Mountain (pl. 3). The workings are mainly in fan material near the mouths of canyons at the range front (Hill, 1915, p. 91) ; placer deposits also have been found in older terrace gravels and stream bottom gravels. The most productive placers are in the southern part of the range between Copper Canyon and Galena Canyon and in the western part of Copper Basin and the adjacent area. The placer gold has been derived mainly from local sources and has been concentrated during erosion of the source veins.

The early history of placer mining in the Battle Mountain district is not known. It is likely that miners returning from the Alaskan gold rush in 1898 were among the first to test the gravels in some of the valleys; it is reported that some placer showings were discovered 
as early as 1903 by James Dahl. No sustained operations were recorded until 1910 when native gold was found in a lode mine at Bannock. This discovery touched off the Bannock boom and encouraged miners to scour the hills for lode as well as placer deposits.

Placer activity was most intense during 1909-11, the 1920 's, and the 1930's, but production has been greatest since 1951 when the Natomas Co. installed a bucketline dredge on the Copper Canyon fan and began largescale operations.

\section{COPPER CANYON (20)}

Placer mining has been carried on from the mouth of Copper Canyon up the canyon about $1 \frac{1}{3}$ miles. The placer operations were mainly confined to the actual channel, although in places bench deposits were mined on the valley sides. At the height of activities in the 1930 's, about 40 miners were engaged in placer mining in the canyon; none of these deposits was being worked in 1955 .

The principal productive ground was in the lower part of the canyon on the Guy Davis, Homestake, Oversight, and Comet claims in the SE1/4 sec. 28, T. 31 N., R. 43 E. Mr. Guy Davis is credited with the first location in the canyon in 1909. His claim-the Guy Davis claim-became the center of a legal controversy that resulted in several fundamental decisions by the $\mathrm{Su}$ preme Court concerning mining law (DeSoto and Morrison, 1936, p. 24, 265). The controversy arose from an attempt by the Glasgow and Western Mining Co. to patent a lode claim (Salt Lake No. 3), on which no discovery had been proved, over the producing Guy Davis placer claim. Messrs. Cole and O'Malley, lessees working the placer, fought the patent application, and a decision was rendered in their favor in 1913. This established the precedent that the date of a mineral discovery was the most important factor in determining ownership. No lode discovery had been proved on the previously located Salt Lake No. 3 claim, but a placer discovery had been proved on the overlapping Guy Davis claim.

According to Bonner Cole (oral communication, 1952), who worked in Copper Canyon during the 1930's, the principal placer channel was 8 to 10 feet wide at the "Narrows" (the point where the canyon crosses the 5,500-foot contour). The channel widened up canyon to 25 or 30 feet at the site of the Copper Canyon mine camp (B.M. 5562) and then gradually narrowed again. Just below the camp, the pay channel was as much as $41 / 2$ feet thick; it consisted of a basal gravel layer 18 inches thick composed mainly of boulders of quartz monzonite porphyry which contains only a little gold.
The basal layers was overlain by a gold-bearing layer 3 feet thick that was composed mainly of quartzite and hornfels from the Harmony and Battle Formations. The tenor of this gravel is said to have averaged $\$ 75$ a yard.

The gold recovered near the camp was mainly coarse and angular. Many nuggets contained inclusions of quartz and rock, and this, together with lack of rounding, suggests that the gold was derived from nearby sources. The gold ranged from 830 to 920 fine and averaged about 880 fine, which corresponded to a value of $\$ 17.85$ an ounce (at $\$ 20.67 \mathrm{oz}$ ) ; according to Bonner Cole, the gold recovered from different side gulches draining into Copper Canyon differed in appearance and fineness. The gold in John-John Gulch NE1/4 sec. 28, T. 3, N., R. 43 E.) was higher in fineness than gold mined from adjacent gulches and averaged a little less than $\$ 19$ an ounce (estimated 915 fine).

Ernest Hider, who worked in the upper part of Copper Canyon in 1914, found a quartz-bearing nugget the size of a potato from which gold worth $\$ 440$ (at $\$ 20.67 \mathrm{oz}$ ) was panned after crushing. The nugget was mined from drift workings 27 feet below the surface; the pay streak here was 18 inches to 2 feet thick in smoothly worn gravel.

The production records of Copper Canyon placers are incomplete, but available data are as follows:

Production of placer gold and silver, Copper Canyon, 1913-38 [Furnished by U.S. Bur. of Mines; published with permission of the owner]

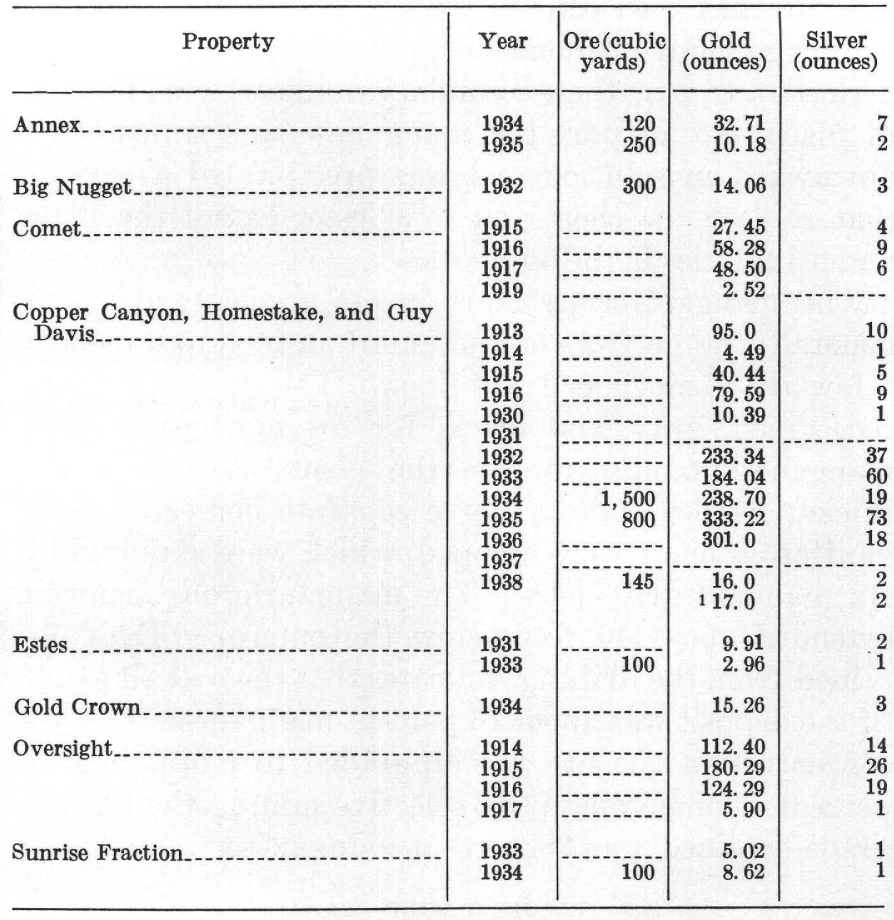

1 Production reported as Guy Davis claim. 
NATOMAS (GREENAN, DAHL) PLACER (5)

The largest placer operation in the quadrangle is the Natomas placer at the mouth of Copper Canyon (pl. 19). Formerly the property was operated under the names Dahl and Christensen, Grand Hills Mining Co., Wilson Placer, and Greenan Placer. The discovery of placer gold in the Copper Canyon fan was made by James Dahl in 1911. Dahl and H. C. Christensen began drift-mining operations in that year and continued until 1920. During the 1920's there was little production. In 1932, Dudley Wilson and associates took over the property and began working gold-bearing gravels near bedrock. In 1935, the Grand Hills Mining Co. leased the property and installed a mechanical washing plant which was operated for a year. Subsequently, other lessees worked the placer intermittently and reported a small annual production. The production diminished gradually during the late 1930's as the richer and more accessible gravels were worked out. Emmett Chase and Charles Caldwell acquired the property about 1937 and in 1939 sold it to James O. Greenan. Greenan began a systematic churn-drilling program, and he proved that the gold-bearing gravel extended for more than 3,200 feet down the fan from the canyon mouth and more than 1,500 feet across the fan. In 1941, the Natomas Co. acquired the placer, but work was suspended with the onset of World War II, and it was not until 1946 that large-scale operations were begun. A drag-line dredge was first used to mine shallow gravels in the upper part of the fan until 1948. In August 1949, a continuous bucket-line dredge with a daily capacity of 9,000 yards and designed for excavating to a depth of 110 feet was put into operation. The water supply is taken mainly from Willow Creek which has a flow of 150 to $800 \mathrm{gpm}$, depending upon the season, and additional requirements are pumped from Buffalo Valley about 2 miles to the south.

Production data for the Copper Canyon fan are fragmentary, but available figures are as follows:

Production of gold and silver, Copper Canyon fan and Natomas placer, 1911-39

[Furnished by U.S. Bur. of Mines; published with permission of the owners]

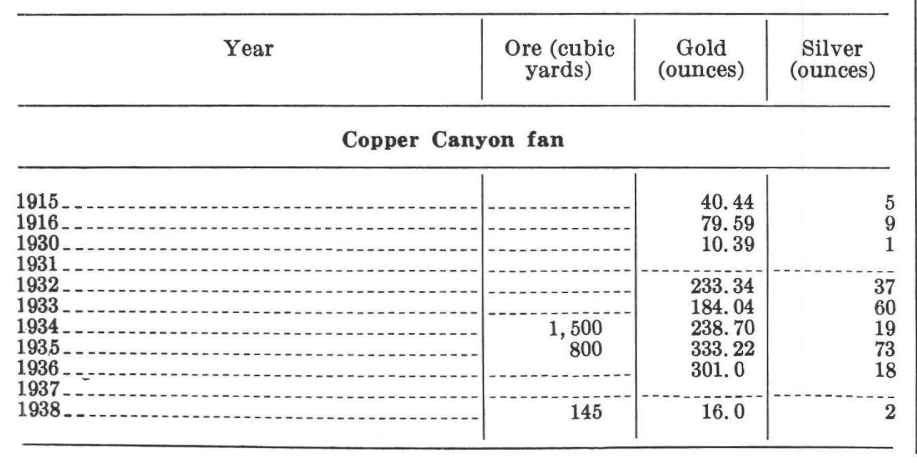

Production of gold and silver, Copper Canyon fan and Natomas placer, 1911-39-Continued

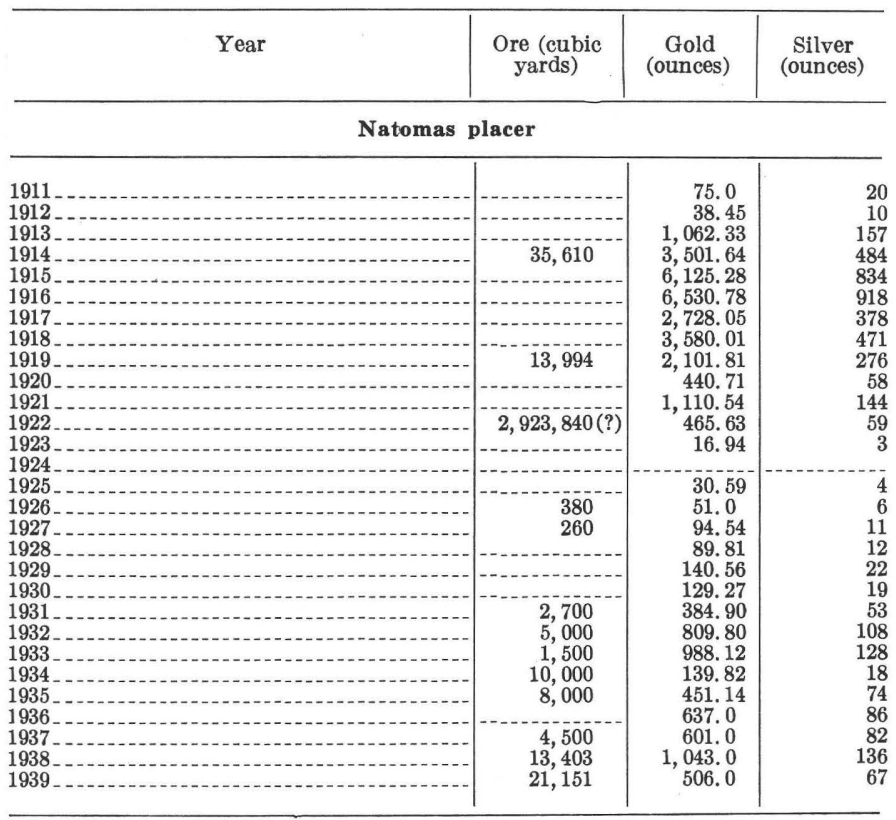

The Copper Canyon fan was drilled on a close-spaced grid prior to the dredging operation. Lines of holes were drilled to bedrock across the fan at intervals of 200 to 300 feet in the upper part and 500 to 900 feet in the lower part (pl. 19). In this way, data were obtained that permitted plotting the configuration of bedrock and the distribution of gold in the fan. The profiles drawn by the writers show that the bedrock surface is far from smooth; deep channels had been cut into the bedrock (largely chert with shale partings) prior to or during the deposition of the fan gravels. In the upper part of the fan (see lines $A$ and $C$ ), there are two distinct channels separated by a bedrock ridge that rose as much as 175 feet above the channels on either side. Near the head of the fan, three distinct channels are shown in profile line $P N$. Along line $G$, two main channels are clearly shown as well as several minor ones. The holes on profile line $K$ did not reach bedrock for the most part, and not much is known about the bedrock configuration south of this line.

The holes were not logged in detail during drilling, but the general distribution of gold in the gravels is known from the assays. These gold values are shown on plate $19 B$ with distinctive patterns. In the upper part of the fan (profiles $P$ and $N$ ), the higher grade gravels form sheetlike bodies, lenticular in detail, overlain by nearly barren fan material. There is only a relatively small proportion of intermediate-grade material, and it is in thin layers. Farther down the fan (profiles $A, C$ ), the richer gravels are in small, thin lenses, seemingly scattered erratically throughout the 
section. Two of the channels in bedrock in profile line $G$ contain high-grade material; one thick lens that evidently was a higher channel filling was cut in hole 8, profile line $E$. The main bodies above bedrock are of intermediate grades and there are thick lenses on the west as well as thin ones on the east.

No detailed studies of the fan materials were made, but is was noted that the gravels on bedrock were fairly well sorted. (See pl. 19B; Roberts, 1964, fig. 23.) This indicates that the gravel was deposited by perennial streams. The overlying fan material cannot be described as a gravel, but rather it is composed of angular boulders in a clayey matrix; the material shows only rude bedding and little sorting. It was probably deposited mainly during floods and includes material in part deposited by torrential streams of short life and in part as mud flows. During the period of fan formation, the regimen of the streams changed markedly from perennial to intermittent. On the whole, the upper beds contain little gold or are barren. This is, presumably, due mainly to the lack of concentration of gold during deposition of the upper fan material during flash floods or mud flows.

The gold being produced from the Copper Canyon fan in 1955 could not be studied because it was being amalgamated during concentration. However, miners who worked drift mines in the canyon during the 1930's made specimens available for study. The gold is relatively coarse, and nuggets up to 5 ounces in weight have been found. The fineness ranged from 830 to 870 and averaged about 860 . The larger nuggets show botryoidal to massive structure and are fairly well rounded. Few of the nuggets had rock adhering to them, but one nugget owned by Dudley Wilson was partly made up of fine-grained rock; a thin section cut of this rock proved to be recrystallized chert, probably from the Pumpernickel Formation.

Between 1952 and 1955, the fineness of gold recovered generally ranged from 850 to 879 fine, but two cleanups were composed of 739 and 788 fine gold. These two were from the western side of the fan, and it is possible that high-silver gold was furnished to this part of the fan from a local source. Such a source might have been the vein system of the Wilson-Independence mine on the ridge north of the placer.

\section{BOX CANYON (3)}

Box Canyon heads just east of the Copper Canyon mine. The canyon trends southeastward for the first half mile of its course then turns southward to the range front following the basalt-Battle Formation contact. Despite the small drainage area at the head of the canyon, it has yielded a notable placer production. The productive part of the channel extended from the 5,900foot contour downstream to the 5,500-foot contour.

The Box Canyon placer deposits were discovered about 1909. Charles Miller is credited with the first production-38.34 ounces in 1910 from the Grandview claim. The major production was made by Fred C. Madsen in 1937-42. The available production records are as follows :

\section{Production of placer gold and silver, Box Canyon, 1910-51}

[Furnished by U.S. Bur. of Mines; published with permission of the owners]

\begin{tabular}{|c|c|c|c|c|}
\hline Property & Year & $\begin{array}{c}\text { Ore } \\
\text { (cubic } \\
\text { yards) }\end{array}$ & $\begin{array}{c}\text { Gold } \\
\text { (ounces) }\end{array}$ & $\begin{array}{c}\text { Silver } \\
\text { (ounces) }\end{array}$ \\
\hline $\begin{array}{l}\text { Blue Jacket and Gold Dollar (Battle } \\
\text { Mountain district) }\end{array}$ & $\begin{array}{l}1914 \\
1915 \\
1916\end{array}$ & & $\begin{array}{r}5.50 \\
68.39 \\
27.09\end{array}$ & $\begin{array}{r}1 \\
18 \\
7\end{array}$ \\
\hline Box Canyon (no claim names) & $\begin{array}{l}1948 \\
1949 \\
1950 \\
1951\end{array}$ & (n) & $\begin{array}{r}2.0 \\
22.0 \\
2.0 \\
1.0\end{array}$ & $\begin{array}{r} \\
\\
\end{array}$ \\
\hline Ellendale_...... & 1911 & $\ldots . .$. & 28.13 & 5 \\
\hline Golden Link & 1941 & 110 & 14.0 & 2 \\
\hline Grand View. - & $\begin{array}{l}1910 \\
1911 \\
1913\end{array}$ & 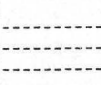 & $\begin{array}{r}38.34 \\
48.16 \\
7.40\end{array}$ & $\begin{array}{r}13 \\
7 \\
1\end{array}$ \\
\hline Henry . . . & 1931 & 400 & 22. 79 & 5 \\
\hline Limelite ....... & 1940 & 1,452 & 14.0 & 2 \\
\hline May Bell.... & 1912 & & 33. 73 & 5 \\
\hline Minnie _....... & 1949 & 500 & 11.0 & 2 \\
\hline Pay Duy & $\begin{array}{l}1934 \\
1935 \\
1936 \\
1939 \\
1940\end{array}$ & $\begin{array}{r}200 \\
105 \\
73\end{array}$ & $\begin{array}{c}23.95 \\
15.12 \\
6.18 \\
23.0 \\
21.0\end{array}$ & $\begin{array}{l}3 \\
2 \\
1 \\
3 \\
3\end{array}$ \\
\hline Pay Day, Gold Eagle, and Ducky .. & $\begin{array}{c}1910 \\
1911 \\
1935 \\
1936 \\
1937 \\
1938 \\
1939 \\
1940 \\
1941 \\
1942 \\
1943-44\end{array}$ & $\begin{array}{r} \\
5,833 \\
3,545 \\
9,276 \\
705 \\
542\end{array}$ & $\begin{array}{r}50.0 \\
10.0 \\
38.09 \\
144.31 \\
24.0 \\
113.0 \\
112.0 \\
426.0 \\
83.0 \\
13.0\end{array}$ & $\begin{array}{r}7 \\
2 \\
3 \\
21 \\
4 \\
14 \\
15 \\
59 \\
13 \\
2\end{array}$ \\
\hline & $\begin{array}{l}1945 \\
1946\end{array}$ & & 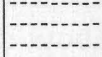 & \\
\hline Tuesday & $\begin{array}{l}1932 \\
1931\end{array}$ & & $\begin{array}{l}20.13 \\
16.59\end{array}$ & 3 \\
\hline
\end{tabular}

The placer workings are in the main channel of Box Canyon and also on terraces on the south side of the canyon. The placer channel in Box Canyon is 30 to 50 feet wide in the widest part east of the Minnie mine, and it narrows up and down canyon. The gold recovered was coarse and subangular and 858 to 874 fine; it occurred mainly on bedrock which was 15 to 20 feet deep in most places. The placers on the south side of Box Canyon have yielded only a small part of the total production. The gravels containing the placer gold are probably terrace gravels deposited before the canyon was incised to its present depth; the gravels are capped by a deeply weathered soil mantle. 
PHILADELPHIA CANYON (BANNOCK) (2)

The Philadelphia Canyon (Bannock) gold placers were discovered in 1909 during the period of boom activity that accompanied the discovery of the rich gold lodes on the Limelite claim. Sprenger (1910, p. 10) mentions that miners were at work on a score of placer claims in January 1910. The claims were staked in Philadelphia Canyon and on the fan and also in the gravels below the basalt on the north side of the canyon (see also Martin, 1910).

The workings in the canyon and on the fan were not highly productive because the great depth of the gravel made operations costly. A shaft near the road intersection (altitude $5,138 \mathrm{ft}$ ) at the mouth of the canyon reached bedrock at 119 feet. Gravel on bedrock is reported to have been of good grade, and a small production was made by drift miners who treated the gravels in rockers and dry washers. The gold is reported by Sprenger $(1910$, p. 10$)$ to have been mostly fine grained, but nuggets up to the size of a pea were found.

According to Ernest Hider who held two claims there in 1955, the gravels below the basalt on the north side of the canyon yielded a rich pocket of placer gold.

Production of placer gold and silver, Philadelphia Canyon (Bannock), 1910-40

[Furnished by U.S. Bur. of Mines; published with permission of the owners]

\begin{tabular}{|c|c|c|c|c|}
\hline Property & Year & $\begin{array}{c}\text { Ore } \\
\text { (cubic } \\
\text { yards) }\end{array}$ & $\begin{array}{c}\text { Gold } \\
\text { (ounces) }\end{array}$ & $\begin{array}{c}\text { Silver } \\
\text { (ounces) }\end{array}$ \\
\hline Bannock..... & $\begin{array}{l}1915 \\
1916\end{array}$ & & $\begin{array}{l}68.94 \\
14.0\end{array}$ & \\
\hline Eva B... & $\begin{array}{l}1938 \\
1939 \\
1940\end{array}$ & $\begin{array}{l}500 \\
500 \\
560\end{array}$ & $\begin{array}{l}52.0 \\
46.0 \\
19.0\end{array}$ & \\
\hline May Bee (June Bug and Maine claims) & $\begin{array}{l}1910 \\
1911 \\
1912\end{array}$ & - & $\begin{array}{r}78.27 \\
6.70 \\
5.52\end{array}$ & $\begin{array}{r}12 \\
1 \\
1\end{array}$ \\
\hline Pactolus & $\begin{array}{l}1915 \\
1927\end{array}$ & - & $\begin{array}{l}18.74 \\
11.80\end{array}$ & $\begin{array}{l}3 \\
2\end{array}$ \\
\hline Wabash and Valley View & 1910 & 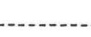 & 16.34 & 2 \\
\hline
\end{tabular}

IRON CANYON (17a)

Placer gold deposits have been mined in Iron Canyon from the Iron Canyon mine camp eastward for more than a mile. The period of principal activity was during the mid-1930's when Ernest Hider and others leased the placer from the San Miguel Nevada Mines, Inc. Mr. Hider reports a production of about $\$ 10,000$ during 1936-38. Production by others is reported to exceed $\$ 5,000$.
Production of placer gold and silver, Iron Canyon, 1917-48

[Furnished by U.S. Bur. of Mines; published with permission of lessor]

\begin{tabular}{|c|c|c|c|c|}
\hline Property & Year & $\begin{array}{c}\text { Ore } \\
\text { (cubic } \\
\text { yards) }\end{array}$ & $\begin{array}{c}\text { Gold } \\
\text { (ounces) }\end{array}$ & $\begin{array}{c}\text { Silver } \\
\text { (ounces) }\end{array}$ \\
\hline Iron Canyon... & $\begin{array}{l}1917 \\
1918 \\
1946 \\
1947 \\
1948\end{array}$ & $\begin{array}{r} \\
-4,210 \\
375 \\
1,050\end{array}$ & $\begin{array}{r}32.55 \\
9.90 \\
114.0 \\
12.0 \\
24.0\end{array}$ & $\begin{array}{r}6 \\
3 \\
19 \\
2 \\
4\end{array}$ \\
\hline Planet_........ & $\begin{array}{l}1934 \\
1935\end{array}$ & $\begin{array}{r}122 \\
5,000\end{array}$ & $\begin{array}{l}17.65 \\
26.49\end{array}$ & $\begin{array}{l}3 \\
3\end{array}$ \\
\hline Ruth C. mine.....- & 1936 & 250 & 45.46 & 7 \\
\hline Ruth and Fraction claim & 1933 & 192 & 21.82 & 3 \\
\hline
\end{tabular}

The valley floor of Iron Canyon is narrow and ranges from 75 to 200 feet wide. According to Mr. Hider, the pay streak was about 5 feet wide and was on bedrock 18 to 22 feet below the surface. The gold was coarse and angular, and nuggets up to 2 ounces were recovered. The gold averaged about $\$ 27$ an ounce in value (at $\$ 35$ an ounce), or about 770 fine.

\section{DUCK CREEK (GALENA CANYON) (30)}

Shafts are scattered along the bottom of Galena Canyon for a distance of about 3 miles, but it is reported that placer production is small. Walter Moore reports that he recovered a few ounces of high-silver gold near the townsite of Galena. Vanderburg (1939, p. 31) mentions that gold has been found in Galena Canyon below the Iron Canyon junction, but that the enclosing alluvium consisted chiefly of boulders and that smallscale placer operations are hampered by a large subsurface flow of water.

\section{COPPER BASIN}

The alluvial fan at the mouth of Long Canyon just south of Copper Basin was explored by drilling by the Natomas Co. in 1946. It is reported that a large volume of low-grade gravel is available in the fan. Some channels contain gravel of higher grade, but not in sufficient volume to warrant operations with gold at $\$ 35$ an ounce.

Production of placer gold and silver, Copper Basin, 1936-37

[Furnished by U.S. Bur. of Mines; published with permission of the owner]

\begin{tabular}{|c|c|c|c|c|}
\hline Property & Year & $\begin{array}{c}\text { Ore } \\
\text { (cubic } \\
\text { yards) }\end{array}$ & $\begin{array}{c}\text { Gold } \\
\text { (ounces) }\end{array}$ & $\begin{array}{c}\text { Silver } \\
\text { (ounces) }\end{array}$ \\
\hline Copper Queen.... & $\begin{array}{l}1936 \\
1937\end{array}$ & $\begin{array}{r}300 \\
1,150\end{array}$ & $\begin{array}{l}7.57 \\
27.0\end{array}$ & 1 \\
\hline
\end{tabular}


VAIL CANYON (63)

The Vail Canyon placer is in Vail Canyon about a mile northwest of Copper Basin. The upper part of the canyon, locally called Poorman's Gulch, drains an area underlain by metamorphosed shale and sandstone of the Harmony Formation and intrusive quartz monzonite porphyry. These rocks are cut by many small gold-bearing veins which were presumably the source of the placer gold.

The property consists of 18 unpatented claims owned in 1955 by Edith Clark and Gordon Estes of Battle Mountain and J. A. Miller of Minden, Nevada. The workings consist of several opencuts and many shallow shafts and pits. Gold was first discovered there by Jasper Vail in 1913 on ground originally located for lode mining (Vanderburg, 1939, p. 32). Vail leased small blocks of ground at 25 percent royalty to individuals who operated small-scale rockers and dry washers. In years of heavy spring runoff, water was brought into Vail Canyon by ditch from Long Canyon and was used for ground sluicing. In 1938-40, a drag-line dredge was installed by the Pacific Placers and operated for a few months in 1940. Operations were hampered by a scarcity of water.

The placer gravel in Vail Canyon ranged from 10 to 30 feet thick. Over much of the area bedrock was less than 15 feet below the surface. The principal concentration of gold was on bedrock, and much of the gravel was mined in drifts along bedrock. Slope-wash and terrace gravels above the main channel were also gold-bearing in places and were mined extensively. The gravel associated with the gold was fairly well rounded and consisted mainly of quartzite and hornfels boulders derived from the underlying Harmony Formation and boulders of quartz monzonite porphyry from the head of the canyon. The gold was coarse and occurred as flat flakes and wire-shaped pieces as well as in generally equidimensional grains that were only slightly rounded. Many grains contained quartz and evidently had not moved far from the source. Gold mined near the divide was reported very coarse and rough. Nuggets weighing an ounce or more were fairly common.

The fineness of the gold ranged from 866 to 915 and averaged about 890 . The shipment of 289 ounces mined in 1940 was 866 fine. Scheelite is a notably accessory mineral in the concentrate. Gordon Estes reports that he has recovered as much as 2 ounces from a yard of gravel. It is reported that up to 1937 the production of the Vail placer was about $\$ 220,000$, but the records are incomplete and this figure cannot be substantiated. The records of production furnished to the U.S. Bureau of Mines follow:
Production of placer gold and silver at Hawkeye and Acacia properties, Vail Canyon placer, 1915-42

[Furnished by U.S. Bur. of Mines; published with permission of the owner]

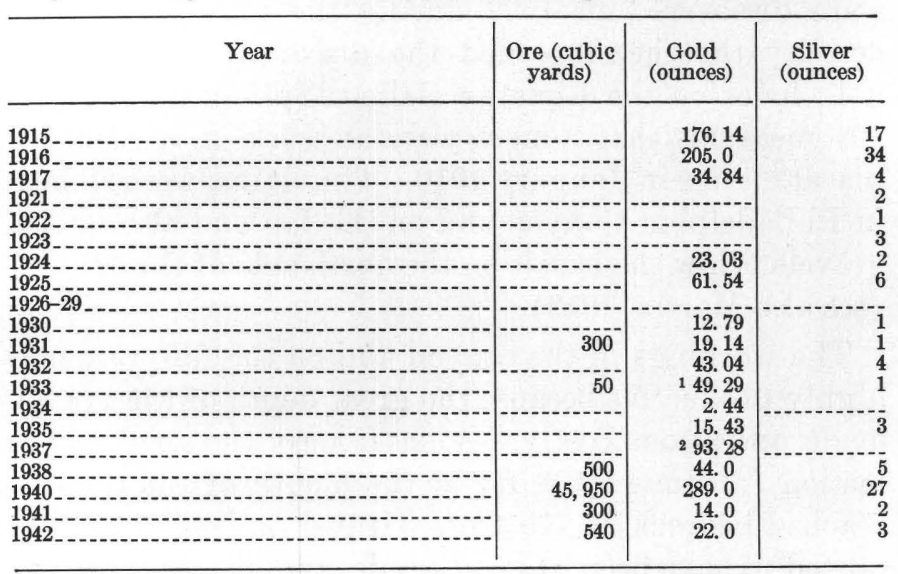

${ }^{1}$ Includes production reported under Hunt property. 2 Vanderburg, 1939, p. 32.

\section{SNOW GULCH AND PIUTE CANYON}

Snow Gulch heads at the divide on the northwest side of Copper Basin and flows northeastward into Humboldt Valley. Piute Canyon is the adjoining canyon on the east (pl. 3). The valley floors of both canyons are narrow within the range, and the valley fill is shallow. The history of early placer operations in the area is not known; records of production show a small production for most years from 1915 to 1926 and in 1931 . The production records are as follows :

Production of placer gold and silver, snow Gulch and Piute Canyon, 1915-31

[Furnished by U.S. Bur. of Mines; published with permission of the owners]

\begin{tabular}{|c|c|c|c|}
\hline Property & Year & $\begin{array}{c}\text { Gold } \\
\text { (ounces) }\end{array}$ & $\begin{array}{c}\text { Silver } \\
\text { (ounces) }\end{array}$ \\
\hline Myra & $\begin{array}{l}1915 \\
1916 \\
1917 \\
1918 \\
1921 \\
1922 \\
1923 \\
1924 \\
1926\end{array}$ & $\begin{array}{r}120.14 \\
141.97 \\
122.0 \\
18.73 \\
19.25 \\
14.09 \\
19.83 \\
7.58 \\
5.0\end{array}$ & $\begin{array}{l}2 \\
4 \\
2 \\
1 \\
2 \\
1 \\
3 \\
1\end{array}$ \\
\hline Piute Canyon & 1931 & 7.19 & 1 \\
\hline
\end{tabular}

1 Production reported under Marietta and Piute mines.

$$
\text { B \& M PLACER (85a) }
$$

The B \& $M$ placer is in secs. 17 and $18, T .32$ N., $R$. 44 E., at the mouths of Snow Gulch and Piute Canyon. The placer was located by Gordon Estes in 1939, and a washing plant was installed and operated by the B \& M Co. in 1940 and 1941. Water for the plant was pumped from the Humboldt Valley. The production totalled about $\$ 47,000$.

Mr. Estes reports that the gold was found for about 2,000 feet down the fan along a channel averaging 
about 30 feet wide. The bedrock averaged 22 feet deep. The gold was coarse-the grain size averaging more than one-eighth inch in diameter-and was generally distributed rather uniformly throughout the gravel. In most places the bedrock had been swept relatively clean of placer gold by the stream, although locally concentrations of coarse gold were found on iron-stained bedrock.

\section{SOURCE OF THE GOLD}

The gold in most of the placers in the Battle Mountain district appears to be of local origin and was derived from lodes by weathering and transported short distances to the place of accumulation. Robert Raring (oral communication, 1952), however, reports that two types of gold have been found in Copper Canyon and Copper Canyon fan. Part of the gold is angular fine gold about 825 fine; another part is coarse, partly rounded nuggets about 880 fine. He suggests that the two kinds were derived from separate sources and were mixed during formation of the placer deposits.

Vanderburg (1939, p. 34) suggested that the gold in the Copper Canyon fan was derived from the goldcopper deposits in Copper Canyon and tributary canyons. Of these, the Copper Canyon mine has been most productive and is credited with about $\$ 1.5$ million in gold. The ore averaged about 0.10 ounce of gold to the ton and was locally richer; this gold is finely divided and is mostly dispersed in pyrite and pyrrhotite. Gold ore shipped from the Tomboy mine averaged about 0.22 ounce to the ton; finely divided gold can be panned from the sulfide ore. Other properties nearby have also yielded gold ore containing fine-grained gold. These mines would be an adequate source for the fine-grained gold.

The source of the coarse nuggets is not so clear. One interesting possibility, however, is suggested by gold occurrences at Copper Canyon; diamond drill holes that were put down west of the Virgin fault zone in the hanging-wall block penetrated gold ore of unusually high value where the holes crossed the Golconda thrust fault zone. The assays of the drill cores are given below; the figures were furnished by the Copper Canyon Mining Co. assay office and are published with their permission:

\begin{tabular}{r|r|r|r|r}
\hline Drill hole & $\begin{array}{c}\text { Depth } \\
\text { (feet) }\end{array}$ & $\begin{array}{r}\text { Gold } \\
\text { (ounce } \\
\text { per ton) }\end{array}$ & $\begin{array}{r}\text { Silver } \\
\text { (ounce } \\
\text { per ton) }\end{array}$ & $\begin{array}{c}\text { Copper } \\
\text { (percent) }\end{array}$ \\
\hline 98 & & $\begin{array}{r}0.21 \\
0.4\end{array}$ & $\begin{array}{r}0.4 \\
.7\end{array}$ & $\begin{array}{r}0.30 \\
.40\end{array}$ \\
\hline
\end{tabular}

This information, together with the statement by $\mathrm{Mr}$. Raring that high gold assays were found at the intersection of the Golconda thrust fault and the Virgin fault in the mine workings, suggests that these structural features may have locally controlled the coppergold metallization. East of the Virgin fault, the upper plate of the Golconda thrust has been eroded except for a small down-faulted segment south of the Copper Canyon mine. However, the thrust zone and upper plate may have contained gold ore bodies which were concentrated in surface deposits during a previous cycle of erosion.

The gold-bearing deposits may have been partly in soil and slope wash and partly in stream gravels. These deposits were covered locally with basalt, as at Philadelphia and Box Canyons, and thus temporarily preserved. Subsequent erosion resulted in transport of the gold and reconcentration in alluvium in stream channels, terraces, and in the fans.

\section{REFERENCES CITED}

Anderson, C. A., Scholz, E. A., and Strobell, J. D., Jr., 1955, Geology and ore deposits of the Bagdad area, Yavapai County, Arizona : U.S. Geol. Survey Prof. Paper 278, 103 p.

Couch, B. F., and Carpenter, J. A., 1943, Nevada's metal and mineral production: Nevada Univ. Bull., v. 37, no. 4, Geol. and Mining Ser. no. 38, $159 \mathrm{p}$.

Cutler, H. C., 1911, Telluride, Nevada: Mining and Sci. Press, v. 102 , no. 25 , p. 845 .

DeSoto, E. D., and Morrison, A. R., 1936, Mining rights on the public domain: 16th ed. San Francisco, Bender-Moss Co., $882 \mathrm{p}$.

Dott, R. H., Jr., 1955, Pennsylvanian stratigraphy of Elko and northern Diamond Ranges, northeastern Nevada: Am. Assoc. Petroleum Geologists Bull., v. 39, no. 11, p. 2211-2305.

Ferguson, H. G., 1929, The mining districts of Nevada: Econ. Geology, v. 24, no. 2, p. 115-148.

Hague, J. D. (1870, Mining industry: U.S. Geol. Explor. 40th Parallel (King), v. 3, 647 p.

Hague, Arnold, and Emmons, S. F., 1877, Descriptive geology: U.S. Geol. Explor. 40th Parallel (King), v. 2, 890 p.

Hill, J. M., 1915, Some mining districts in northeastern California and northwestern Nevada: U.S. Geol. Survey Bull. $594,200 \mathrm{p}$.

Hotz, P. E., and Willden, Ronald, 1964, Geology and mineral deposits of the Osgood Mountains quadrangle, Humboldt County, Nevada: U.S. Geol. Survey Prof. Paper 431, 128 p.

Kuenen, P. H., 1953, Significant features of graded bedding: Am. Assoc. Petroleum Geologists Bull., v. 37, no. 5, p. 1044-1066.

Martin, A. H., 1910, The Bannock mining district, Nevada: The Mining World, v. 32, no. 17, p. 835.

Merriam, C. W., and Anderson, C. A., 1942, Reconnaissance survey of the Roberts Mountains, Nevada: Geol. Soc. America Bull., v. 53, no. 12, pt. 1, p. 1675-1727.

Morris, H. T., and Lovering, T. S., 1952, Supergene and hydrothermal dispersion of heavy metals in wall rocks near ore bodies, Tintic district, Utah: Econ. Geology, v. 47, no. 7, p. $685-716$.

Nolan, T. B., 1928, A late Paleozoic positive area in Nevada: Am. Jour. Sci., 5th ser., v. 16, p. 153-161.

Nolan, T. B., Merriam, C. W., and Williams, J. S., 1956, The stratigraphic section in the vicinity of Eureka, Nevada: U.S. Geol. Survey Prof. Paper 276, 77 p. 
Raymond, R. W., 1869, Mineral resources of the States and Territories west of the Rocky Mountains: Washington, U.S. Treasury Dept., 256 p.

1872, Statistics of mines and mining in the States and Territories west of the Rocky Mountains: Washington, U.S. Treasury Dept. [3d rept.], 566 p.

1873, Statistics of mines and mining in the States and Territories west of the Rocky Mountains: Washington, U.S. Treasury Dept., 5th Ann. Rept., 550 p.

1874, Statistics of mines and mining in the States and Territories west of the Rocky Mountains: Washington, U.S. Treasury Dept., 6th Ann. Rept., 585 p.

Roberts, R. J., 1949a, Geology of the Antler Peak quadrangle, Nevada: U.S. Geol. Survey open-file report, 108 p. Aug. 22, 1949.

- 1949b, Structure and stratigraphy of the Antler Peak quadrangle, north-central Nevada [abs.]: Geol. Soc. America Bull., v. 60, no. 12, pt. 2, p. 1917.

- 1951, Geology of the Antler Peak quadrangle, Nevada: U.S. Geol. Survey Geol. Quad. Map GQ-10, scale, $1: 62,500$.

- 1960, Alinement of mining districts in north-central Nevada: U.S. Geol. Survey Prof. Paper 400-B, art. 9, p. B17-B19.

- 1964, Stratigraphy and structure of the Antler Peak quadrangle, Nevada: U.S. Geol. Survey Prof. Paper 459-A, p. A1-A90. (In press.)

Roberts, R. J., Hotz, P. E., Gilluly, James, and Ferguson, H. G., 1958, Paleozoic rocks of north-central Nevada: Am. Assoc. Petroleum Geologists Bull., v. 42, no. 12, p. 28132857.

Roberts, R. J., and Lehner, R. E., 1955, Additional data on the age and extent of the Roberts Mountains thrust fault, north-central Nevada [abs.]: Geol. Soc. America Bull., v. 66 , no. 12, pt. 2, p. 1661.

Sager, G. V., 1941, Climate of Nevada, in Climate and man: U.S. Dept. Agriculture Yearbook, p. 979-988.

Schrader, F. C., 1933, The Battle Mountain mining district, Nevada: U.S. Geol. Survey open-file report.

Sprenger, W. O., 1910, The Bannock gold rush: Austin, Nev., Reese River Reveille.

Vanderburg, W. O., 1939, Reconnaissance of mining districts in Lander County, Nevada: U.S. Bur. Mines Inf. Circ. 7043, $83 \mathrm{p}$.

Walcott, C. D., 1908, Cambrian sections of the Cordilleran area, in Cambrian geology and paleontology: Smithsonian Misc. Collns., v. 53, no. 5, p. 167-230.

Waring, G. A., 1918, Ground water in Reese River basin and adjacent parts of Humboldt River basin, Nevada: U.S. Geol. Survey Water-Supply Paper 425-D, p. 95-129.

Whitehill, H. R., 1873, Biennial report of the State Mineralogist of the State of Nevada for the years 1871 and 1872: Carson City, $191 \mathrm{p}$.

1875, Biennial report of the State Mineralogist of the State of Nevada for the years 1873 and 1874: Carson City, $191 \mathrm{p}$.

1877, Biennial report of the State Mineralogist of the State of Nevada for the years 1875 and 1876: Carson City, $226 \mathrm{p}$.

1879, Biennial report of the State Mineralogist of the State of Nevada for the years 1877 and 1878: San Francisco, $212 \mathrm{p}$.

Young, G. J., 1915, A cave deposit [Battle Mountain, Nevada] : Econ. Geology, v. 10, p. 186-190. 


\section{INDEX}

[Italic page numbers indicate major references]

Accessibility

Ace of Diamonds claim

Acknowledgments

Actinolite

Albite.

Alluvium.

Amphiboles.

12

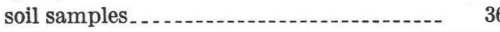

Anglesite.............. 20, 30,33

Annie Blaine claim 62

Antimony, distribution..................... 20 on North Peak

Antimony deposits, general................. 39 zonal pattern

Antimony King mine.... 20, 79

Antler block................ 16

Antler orogeny . . ............ 6, 15 Antler Peak Limestone...._-_._. 6, 8, 9, 38, 50, 64, 65 Antler Peak project, history

Antler sequence.

Apatite_............... 13,14

Apex Antimony mine.

Aquifers........ 4

Area_nentite.

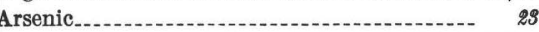

Arsenopyrite . ..... 28, 26, 27, 31, 32, 35, 36, 37, 51, 52, 75

Atlas claim

Augite_._. 15

Azurite..................................... 19, 31, 32

B \& M placer.

Badger claim.........-...- 69

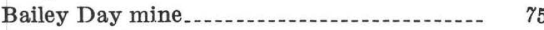

Balch workings...... 66

Barite..... 14, 24, 44

Basalt_....-.--on 15

Bastin, E. S., cited._. 69

Battle Formation, description....... 8 $11,25,37,41,43,46,48,52,56,58,64,65,76$

metamorphism...... 18

Battle Mountain, location............ 4

Battle Mountain district, description.-...-.- $\quad 38$

location -

Battle Mountain Mining Co

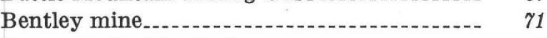

Berry, W. B. N., cited.......... 7

Big Four mine

Big Pay mine . .

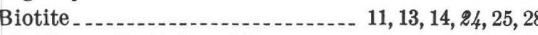

Biotite-cordierite hornfels . . . . . .

Bismuth . . -

Black Rock mine .

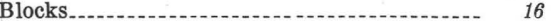

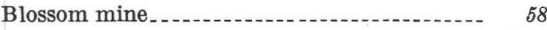

Blue Gem Turquoise mine . . . .

Bon Ami claim................. 59

Boulangerite _........ 28, 33

Box Canyon placers

Brachiopods, Edna Mountain Formation...- 9

Braunite . . . -

$\begin{array}{lr}\text { Bridge, Josiah, cited } & 7 \\ \text { Bryan mine. } & \end{array}$

Buckingham claim. 72

Buckingham mine. See O'Leary mine.
-
Page

$\begin{array}{ll}\text { Buena Vista fault } & \\ \text { Buena Vista mine. }\end{array}$

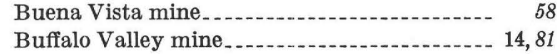

Butte fault

Butte mine_.......................... 22, 63

Buzzard fault

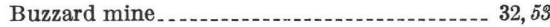

Buzzard vein

C

Cadmium -.........-.

Calamine

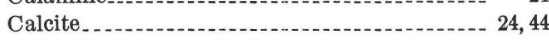

Caldwell, Charles, cited ................... 85

Cambrian System

Carbonate assemblage

Carissa mine

Cave adit . . .

Celia claim

Cerargyrite.

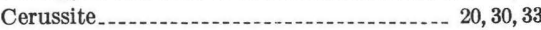

Chalcanthite .

Chalcocite..... 18, 30, 31, 44

Chalcopyrite _. _ $18,23,26,27,31,32,33,35,36,44,50,52$

Chase mine _._........ 64,69

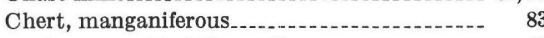

Pumpernickel Formation.-...- 12

Scott Canyon Formation...-..-.-.-. 14

Chessher, H. B._... 49, 52, 53, 54, 61

Chloride.

Chlorite.

$14,28,24,28,44$

Chrysocolla _._. 19, 30, 31, 32

Clay minerals

Cleveland claim.

Climate...................... 4

Cole, Bonner, cited................... 84

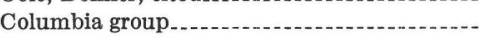

Compromise claim

Conodont fauna, Pumpernickel Formation.--

Contention fault

Contention mine

Copper, Bailey Day mine, 1934-48_... 75

Bentley mine, 1923-49.

Big Pay mine, 1929-37_....... 77

Buena Vista mine, 1935-40 ............. 59

Butte $\mathrm{min}$

Buzzard mine, 1912-41.

Carissa mine, 1936-54...

Contention mine, 1927-54

Copper Basin area, 1916-53.

Copper Canyon mine, 1871-1954.

Copper King mine, 1936-54

Copper Queen mine, 1917-51............

Dewitt mine, 1934-50.

distribution

18,19

Gold Cash mine, 1934-43..

Golden Era group, 1908-40

Gracie mine, 1917-28.

Hard Times claim, 1941-48..

Henrietta mine, 1937-54.

Humbug-Lucky Chance mine, 1021-43

Iron Canyon mine, 1908-41.

Little Giant mine, 1903-36.

Lucky Strike mine, 1908-52

Meagher mine, 1904-35.
Copper-Continued Page

Moonlight mine, 1919-48_......... 60

Morning Star mine, 1905-38_..-_-.--_-_ $\quad 76$

Nevada mine, 1902-48

O'Leary mine, 1913-29............... 72

Pedro mine, 1937-54_................ 70

Peggy group, 1935-36_._- 71

Plumas mine, 1919-43............... 56

Post mine, 1945-47............ 63

prospecting 1902-57

Ridge mine, 1924-39_... 77

Surprise mine, 1937-54__. 66

Sweet Marie mine, 1928-54_._._._._._._. 65

Tomboy mine, 1925-49.... 51

Trinity mine, 1875-1951_..-_.-- 60

$\begin{array}{rr}\text { Widow mine, 1927-45. } & 68 \\ \text { pper Basin area, mines. } & 64\end{array}$

$\begin{array}{ll}\text { Copper Basin area, mines. } & 64 \\ \text { Copper Basin placers } & 87\end{array}$

Copper Canyon, metallization. ...........- 25

placer mining

quartz monzonite...........- 10

Copper Canyon-Iron Canyon area, mines.--- 40

Copper Canyon mine.................. 13, 17, $19,20,23,24,27,28,31,32,35,37,38.40,41$

Copper Canyon Mining Co........... 64

Copper deposits, supergene.................. $\quad 30$

Copper Glance group. ........... 79

Copper-gold and copper deposits, zonal pattern.

Copper-gold ore bodies, Copper Canyon mine $\quad 44$

Copper-gold veins.............. 31

Copper King fault....................... 66

Copper King mine.............. 22, 64, 66

Copper Prize mine

Copper Queen mine........ 19, 73

Copperopolis adit_................. 70

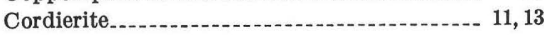

Covellite................. 18

Crawford, Charles........................ 51

Cretaceous orogeny . .

Crowe, H. E.. analyst._.

Crown Point Extension claim
Cuprite..... 71

$\mathrm{D}$

Dahl, James, cited

Dead Horse mine.

Dewitt block

Dewitt fault................................... 68

Dewitt mine

Dewitt thrust.......... 8,16

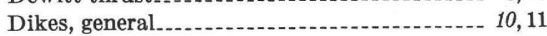

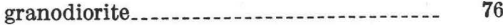

quartz monzonite.

Diopside............... 11, 14, 24, 28, 35

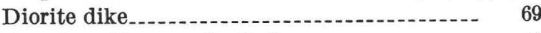

Douglass, Raymond, cited ................. 8

Driscol mine_.... 20,61

Duck Creek placers.

Duncan, Helen, cited..................... 6

Duval Co... 43,64

E

Eagle mine

Edna Mountain Formation..... 6, 8, 9, 38, 50, 57,58

Edna Mountain Limestone........... 51

Elder Creek area, mines ..................... $\quad 76$ 


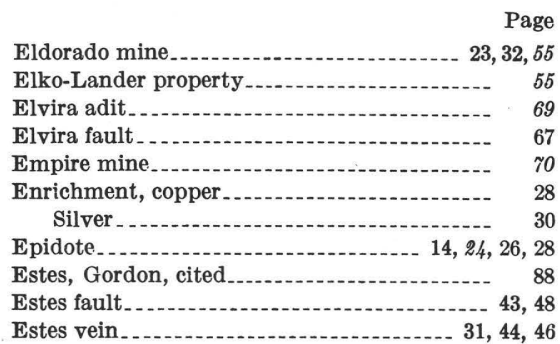

Fairview claim

Faults, Copper Canyon mine area...... 43, 46, 48 Golconda block . high-angle........... 17

Plumas mine area. prospected . .

Feldspar, relict.-....- 14

Ferguson, H. G., cited

Fieldwork

Flood-plain deposits..- 10

Folds . . . 15, 16

$\begin{array}{lr}\text { Fossils, Antler Peak Limestone } & 8 \\ \text { Fuller group } & 79\end{array}$

G

G \& C workings. Galena. Canyon area. Gangue minerals................ 23, 35 Garnet. . . . Garnet-diopside-actipolite hornfels, Battle Formation

Geochemical prospecting.

Geologic history.

Geology, Copper Basin area

Copper Canyon mine area-

Nevada mine.

Glasgow and Western Exploration $\mathrm{Co}_{-}-{ }_{-}$

Goethite ........... 22

Golconda block.

Golconda thrust fault . ............. 6, 48, 50, 57

Gold, Bailey Day mine, 1934-48........ 75 Bentley mine, 1923-49.

Big Four mine, 1935-38

Big Pay mine, 1929-37.

Box Canyon placers, 1910-52

Buena Vista mine, 1935-40.

Butte mine, 1866-1947.

Buzzard mine, 1912-

Carissa mine, 1936-54

Contention mine, 1927-54

Copper Basin area, 1916-53

Copper Basin placers, 1936-37.

Copper Canyon placers, 1913-38

Copper King mine, 1030-54

Copper Queen mine, 1917-51.

Dewitt mine, 1934-50

General_.................... 17, 26, 28, 33, 36, 44

Gold Cash mine, 1934-43...

Golden Era group, 1908-40

Gracie mine, 1917-28

Hard Times claim, 1941-48

Henrietta mine, 1937-54

Humbug-Lucky Chance mine, 1921-43

Irish Rose mine, 1922-24.

Iron Canyon mine, 1908-41.

Iron Canyon placers, 1917-48.

Lucky Strike mine, 1908-52

Meagher mine, 1904-35

Moonlight mine, 1919-48.

Morning Star mine, 1905-38

Natomas placer, 1911-39.
Gold-Continued

Nevada mine, 1902-48

O'Leary mine, 1913-29.

Pedro mine, 1937-54.

Peggy group, 1935-36

Philadelphia Canyon placers, 1910-40

Piute Canyon placer, 1915-31............-.

placer deposits.

Plumas mine, 1919

Post mine, 1945-47.

prospecting 1902-57.-

Ridge mine, 1924-39.

Silver King mine, 1934-39

Snow Gulch placer, 1915-31

Surprise mine, 1937-54

Sweet Marie mine, 1928-54

Telluride mine.

Tomboy mine, 1925-49.

Trinity mine, 1875-1951

Vail Canyon placer, 1915-42

Widow mine, 1927-45

Wilson-Independence mine, $1038-56$

Gold Cash mine.

Gold nuggets.

Gold-silver deposits, description

zonal pattern

Gold Top mine.-.

Golden Era group.

Golden Era mine.-

Goslarite -

Gracie mine.

Granodiorite at Trenton Car

Graptolites.

Gravels.

Greenockite...................................

Ground water, source of water supply......-

Ground-water basins.

Gulch fault

Gypsum - 30,33

$\mathrm{H}$

Halloysite $24,28,30,31$

Hard Times claim
Hardy mine

Harmony Formation.....-6, 8, 11, 14, 20, 25, 27, 36, $41,43,46,48,53,54,56,58,60,61,64,65,66,67$, $68,69,76$.

Hass, Wilbur H., cited

Havallah Formation

Hawkeye mine............................. 74

Hayden fault, description prospecting

Hematite $\ldots$

Hemimorphite............................. 21, 33

Henbest, Lloyd, cited..................... 8

Henrietta mine....... 69

Hider, Ernest, cited.... 84, 87

Hill, J. M., quoted

Hinman, G. C........ 54

Hornfels..................... 13, 14, 26, 27, 30, 44

Hornfels ore body, Copper Canyon mine _. $32,45,48$

Humboldt claim.

Humbug-Lucky Chance mine

Hydromica _................................ 27

Hydrothermal, stages.

Hydrozincite................................. 21

Hypogene minerals............ 18, 20, 21, 22, 23, 30

Hypogene stage, copper-gold veins............ 31

28,30

Independence mine.

Independent claim.

Irish Rose mine................ 20, 23, 75

Iron

Iron Canyon area.

Iron Canyon claim.
$\mathbf{K}$

Kaolin ......- 30, 31

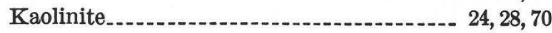

Kelly fault

$\mathbf{L}$

Langwith, J. A., cited_._._... 57

Lauritzen mine

Lead, Bailey Day mine, 1934-48.

Bentley mine, 1923-49. 71

Big Four mine, 1935-38................ 54

Big Pay mine, 1929-37............. 77

Buena Vista mine, 1935-40 .

Butte mine, 1866-1947 .................. 63

Buzzard mine, 1912-41................ 54

Copper Canyon mine, 1871-1954_.....-.- 42

Copper Queen mine, 1917-51..-_-.-_-.-. 73

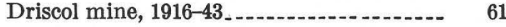

general _....... 20, 36

Gold Cash, 1934-43...-..- 53

Golden Era group, 1908-40 -

Hard Times claim, 1941-48 _...-..--_-_ 59

Humbug-Lucky Chance mine, 1921-43 _.. 61

Irish Rose mine, 1922-24_..._........- 75

Iron Canyon mine, 1908-41 .............. $\quad 49$

Little Giant mine, 1903-36.............. 74

Lucky Strike mine, 1908-52_...-..- 78

Meagher mine, 1904-35_._._._._....... 55

Moonlight mine, 1919-48_............. 60

Nevada mine, 1902-48 ................. 50

O'Leary mine, 1913-29.................. 72

Plumas mine, 1919-43...............-...- 56

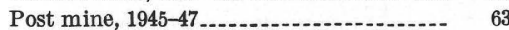

prospecting 1902-57

Ridge mine, 1924-39.

Tomboy mine, 1925-49........

Trinity mine, 1875-1951

White and Shiloh mine, 1937-51...

Lead anomalies.

Lead-silver deposits.

Lead-zinc ore bodies, Copper Canyon mine.--

Lead-zinc-silver deposits, description........... zonal pattern

Lead-zinc veins

Limonite.

(22, 23

Lode deposits

Lucky Strike fault, prospecting

Lucky Strike mine.

Lucky Strike vein.

M

Magnetite

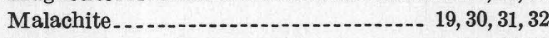

Manganese.

Manganese oxides

22,83

Marcasite.

Marigold mine

ert, analyst................... 36

Melanterite

Mercury claim

Metamorphic zones

Metamorphism, contact stage 11

hydrothermal stage

igneous rocks.

sedimentary rocks.

Metasomatic orthoclase

Metasomatic plagioclase.

(n)

(1)

8
75
71
54
77
59
63
54
42
73
61
36
53
80
59
61
75
49
74
78
55
60
50
72
56
63
40
77
51
60
57
36
75
44
38
35
33
23
40
37
78
39




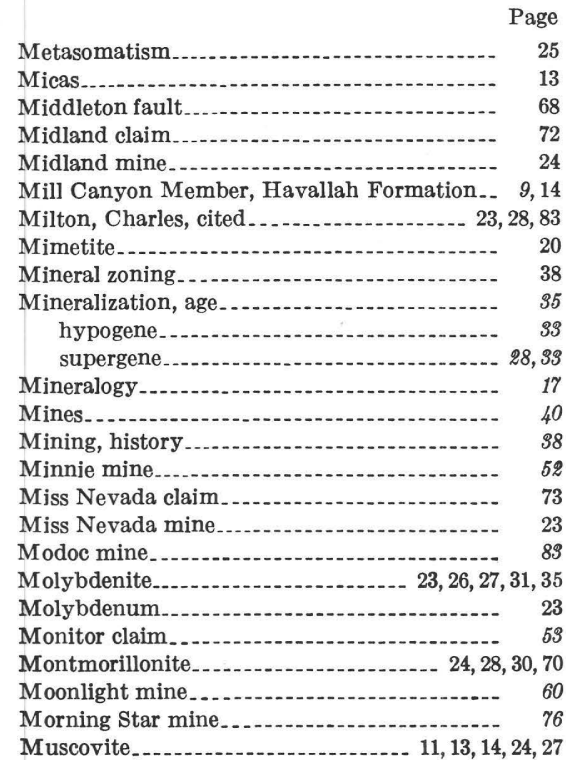

$\mathrm{N}$

Native copper

Natomas placer

Neptune claim.

Neuerburg, Faye

Nevada mine................ 20, 21, 24, 40, 50

Nevada-Omaha mine....................... 17,54

Nevada-Omaha vein

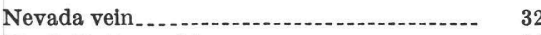

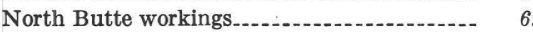

Northern Light workings.......-............-. 70

Northland claim........- 72

0

O'Leary mine .............. 18, 20, 28, 72

Olivine.

Olivine basalt

Ordovician System

Ore bodies, Harmony Formation. 8

Ore deposits, Copper Basin area............. 65

Copper Canyon mine

distribution................................. 17

general character and classification.-...-.- $\quad 25$

Nevada mine............................... 50

zonal arrangement.........................- 39

Ore-bearing faults.......... 17

Orogeny

Orpiment..................................... 23

Orthoclase_....................... 11, 13, 14, 24, 25, 26, 27

Osgood Mountain quarzite............. 6

Overlap assemblage. . . . .

Oxidized zone.............. 28, 29, 30

Oyarbide Ranch.

\section{$\mathrm{P}$}

Paleozoic facies

Paleozoic sedimentary rocks._._._._._....... 6

Pedro mine.

Peggy group

71
0

$\begin{array}{ll}\text { Philadelphia Canyon } & 54 \\ \text { Philadelphia Canyon placers. } & \end{array}$

Phosphoria Formation.................... 9

Physical features.............................. 4

Pisanite

Piute Canyon placer...................... 88

Placer deposits. ................ 83

Plagioclase-. -

Planet claim

Plumas fault, description prospecting
Page

Plumas mine....................... 22, 32, 37, 40, 55

Plumbojarosite

20
$18,33,74$

Polybasite... 18, 33, 74

$\begin{array}{ll}\text { Post mine... } & 63 \\ \text { Postore faults. }\end{array}$

Potassic metasomatism.

Preble Formation.

Precipitation.

Previous work

Production. See under Copper, Gold, Lead, Silver, Zinc.

Propylitization

Prospecting, geochemical suggestions for further.................... 37

Proustite................ 18, 33

Psilomelane.........-...-... 23, 83

Pumpernickel Formation, general ............ 6, $9,11,43,50,51,57,58,59,83,86$

metamorphism

Pyrargyrite _..._........... 18, 74 Pyrite..._. 21, 22, 26, 27, 28, 31, 32, 33, 35, 36, 37, 44, 50, 52

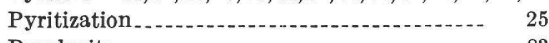
Pyrolusite Pyrrhotite Q

Quality of the water

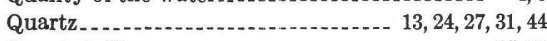
Quartz latite - . Quartz monzonite................... 10, 41, 64, 68, 88 Quartz monzonite porphyry dike...-...-..- 54 Quaternary System......... 9 Quaternary volcanic rocks.................. 14

Range-front faults..R 17 Raring, R. H., cited

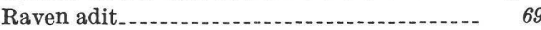
Raven claim Realgar.

Red Rock group..................... Replacement deposits, copper-gold lead-zinc-silver. . . . . . . 32 Richellite _........................... 30, 31, 70 Ridge mine...................... 19, 77 Roberts Mountains. Roberts Mountains thrust:_................ 38 Ross, Jr., R. J. cited ...........

\section{$\$$}

Scheelite. $23,25,27,35,67,88$

Schmidt, F. Sommer

Scorodite.... 23, 30

Scott Canyon block ............... 10

Scott Canyon Formation...... 6, 10,11, 14, 23, 36, 40 ,

Sedimentary rocks ..................... $49,54,60,61,63,7$

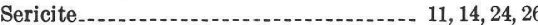
Shale, Scott Canyon Formation........ 14 Shiloh vein

Shoreline deposits

Shovelin, D. F Siderite... $25,28,33,44$ Silicates...............................

Siliceous assemblage ....................... 6,16

Siliceous hornfels, Battle Fiormation....-..--. 12

Silver, Bailey Day mine, 1934-48_......... $\quad 75$

Bentley mine, 1923-49................ 71

Big Four mine, 1935-38_............. 54

Big Pay mine, 1929-37 .......................

Box Canyon placers, 1.910-52

Buena Vista mine, 1985, $40 \ldots . . . . . . . . .$.

Butte mine, 1866-1947.

Buzzard mine, 1912-41

Carissa mine, 1936-54

Contention mine, $1927^{\prime}-54$

Copper Basin area, 1916-53.

Copper Basin placers, 1936-37.

Copper Canyon mine, 1871-1954

Copper Canyon placers, 1913-38........
Silver-Continued

Copper King mine, 1936-54

Copper Queen mine, 1917-51 ............ 73

Dewitt mine, 1934-50

distribution....................... 18, 30, 33, 36

Driscol mine, 1916-43 _................ 61

Golden Era group, 1908-40.-........- 80

Gracie mine, 1917-28................... 77

Gold Cash mine, 1934-43

Hard Times clajm, 1941-48_.......-.- 59

Henrietta mine, 1937-54

Humbug-Lucky Chance mine, 1921-43_..- 61

Irish Rose mine, 1922-24_................- 75

Iron Canyon mine, 1908-41.............- 49

Iron Canyon placers, 1917-48 _.........- 87

Little Giant mine, 1903-36_............ 74

Lucky Strike mine, 1908-52 _._._.......-. 78

Meagher mine, 1904-35................ 55

Moonlight mine, 1919-48................ 60

Morning Star mine, 1905-38_......... 76

Natomas placer, 1911-39................ 85

Nevada mine, 1902-48................... 50

O'Leary mine, 1913-29............... 72

Pedro mine, 1937-54

Peggy group, 1935-36

Philadelphia Canyon placers, $1910-40 \ldots . . . \quad 87$

Piute Canyon placer, 1915-31............ 88

Plumas mine, 1919-43.................- 56

Post mine, 1945-47..................... 63

prospecting, 1902-57-...... 40

Ridge mine, 1924-39........... 77

Silver King mine, 1934-39

Snow Gulch placer, 1915-31............. 88

Surprise mine, 1937-54_.............. 66

Sweet Marje mine, 1928-54_............. 65

Tomboy mine, 1925-49 $\ldots$

Trinity mine, 1875-1951............... 60

Vail Canyon placer, 1915-42_...-..... 88

White and Shiloh mine, 1937-51........- 57

Widow mine, 1927-45................ 68

Wilson-Independence mine, 1938-56 ......- 51

Silver King mine-......................... 53

Silver sulfosalts

Sioux group . . .

Smithsonite.

Snow Gulch placer................... 88

Sonoma orogeny

Spanish claim. ............. 59

Sparrow claim

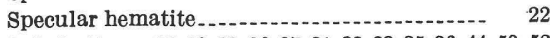

Sphalerite _.- 17, 20, 23, 26, 27, 31, 32, 33, 35, 36, 44, 50, 52

Sphene._...................... 24

Spotted hornfels

Stalagmites

Stibnite

Strathearn Formation

Structure

Supergene minerals............. 18, 20, 21, 22, 23, 30

Supergene stage, copper-gold veins..........- 32

Superior fault . . . . .

Superior vein .

Surface water-1 4

Surprise mine

Tactite

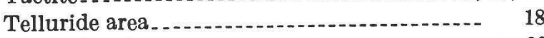

Telluride mine................................... 83

Telluride minerals........................... 35, 83

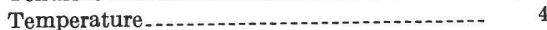

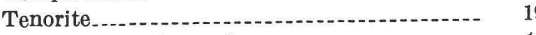

Tertiary intrusive rocks...................... 10

Tertiary volcanic rocks....................... 14

Tetradymite. . . . . .

Tetrahedrite. . .

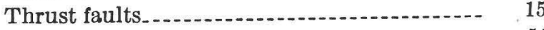

Tomboy mine.......... 51

Tourmaline.

Transitional assemblage.................... 6,

Tremolite 


\begin{tabular}{|c|c|}
\hline \multicolumn{2}{|l|}{ Page } \\
\hline Trenton Canyon, granodiorite.................. & Valmy Formation \\
\hline Trenton Canyon anticline....................... & Veins, lead-zinc-silver deposits........... 32 \\
\hline Trenton Canyon Member, Havallah Forma- & Vinini Formation. \\
\hline tion. & Virgin fault_. $\ldots . .17,38,43,44,46,48,50,56,57,58$ \\
\hline Trenton Canyon syncline.... & Virgin vein, description. \\
\hline Trenton Copper prospect....-...- & discovery \\
\hline Trenton mine. & Volcanic assemblage \\
\hline Trilobites, Harmony Formation & Volcanic material \\
\hline Trinity fault, description............. 17, 57, 60,61 & \\
\hline prospecting & W \\
\hline Trinity mine. & Wad.... \\
\hline Trinity vein & Water supply... \\
\hline 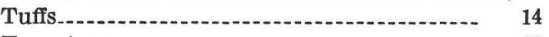 & Welded tuffs. \\
\hline Tungsten & Wells \\
\hline Turquoise, Copper Basin area, 1916-53 & West fault... $43,44,46$ \\
\hline distribution.........- & Western Lock mine... \\
\hline & White and Shiloh mine \\
\hline $\mathrm{U}$ & White vein \\
\hline Uncle Tom claim & Widow mine... 19,68 \\
\hline & Wilson, Dudley \\
\hline - & Williams, James Steele, cited.-1, 8,9 \\
\hline almy block & $\begin{array}{l}\text { Wilson-Independence mine } \\
\text { Windfall Formation }\end{array}$ \\
\hline
\end{tabular}

age

57,58

47

16

\begin{tabular}{|l}
4 \\
4 \\
4 \\
8 \\
8 \\
8
\end{tabular}
Page
Wollastonite

11,14
Y

(14)

Z

Zinc, Copper Canyon mine, 1871-1954_-.-.-- $\quad 42$ distribution. ............. 20,36

Humbug-Lucky Chance mine, 1921-43...- 61

Irish Rose mine, 1922-24_............... $\quad 75$

Lucky Strike mine, 1908-52

Moonlight mine, 1919-48................. 60

Nevada mine, 1902-48_..................- 50

O'Leary mine, 1913-29........................ 72

prospecting, 1902-57_......... 40

Trinity mine, 1875-1951

White and Shiloh mine, 1937-51........- 57

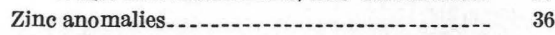

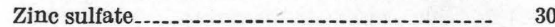

Zoisite

Zonal pattern, copper-gold and copper de-

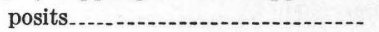

\section{.}

66
5
78
60
50
72
40
60
57
36
30
28
93

